Alllu2 154554

NATL INST OF STANDARDS \& TECH R.I.C.

A11102154554

/NBS bullding sclence serles
TA435.U58 V146:1983 C. 1 NBS-PUB-C 1974

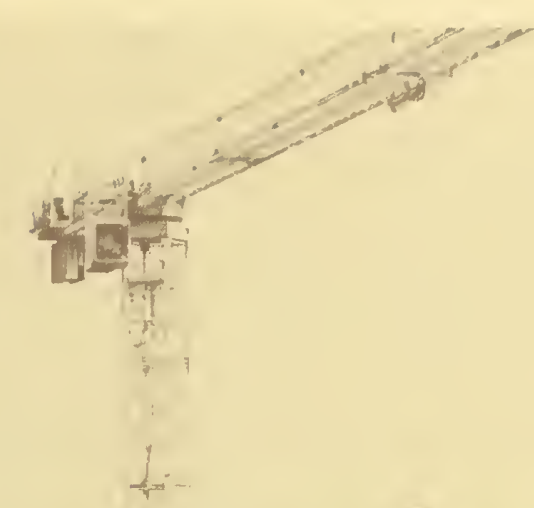

)

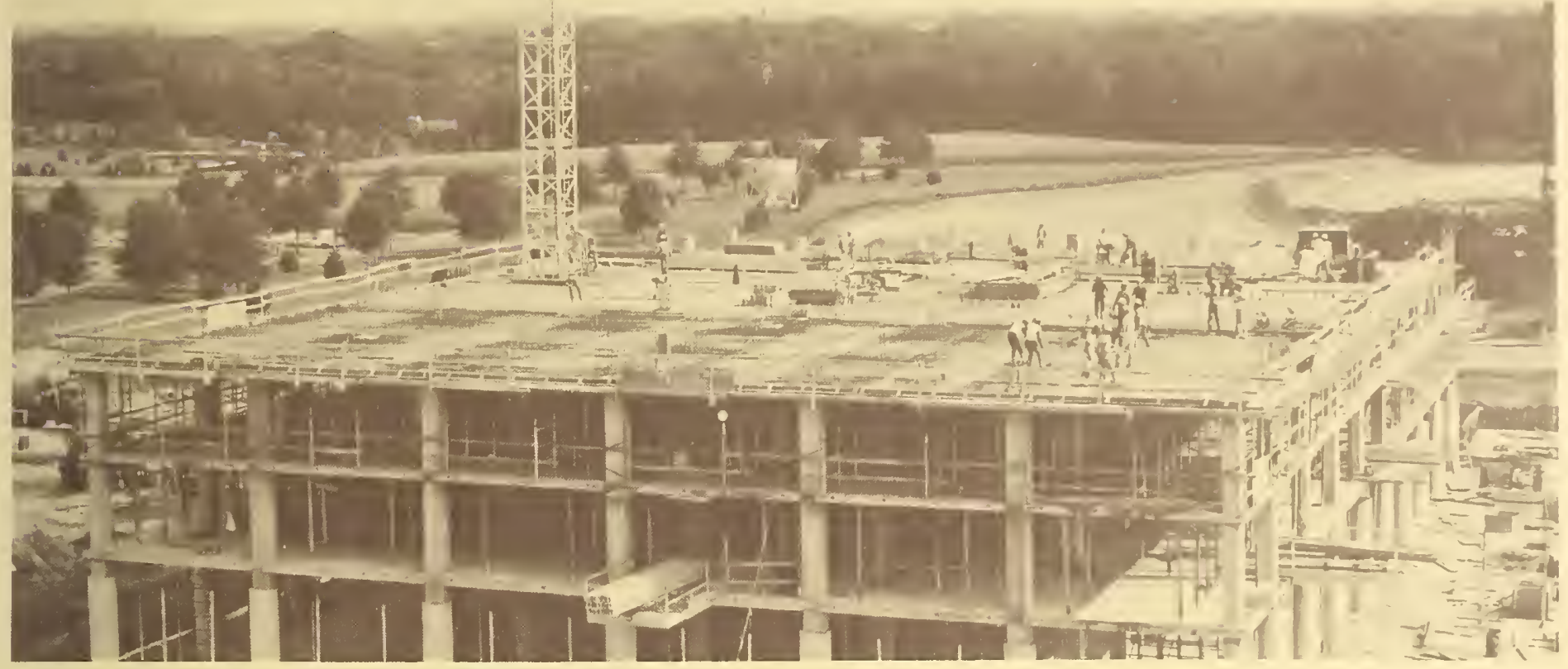

NBS BUILDING SCIENCE SERIES 146

\title{
Evaluation of Construction
} Loads in Multistory Concrete TA

435 ildings .458

146 1983 


\section{NATIONAL BUREAU OF STANDARDS}

The National Bureau of Standards' was established by an act of Congress on March 3, 1901. The Bureau's overall goal is to strengthen and advance the Nation's science and technology and facilitate their effective application for public benefit. To this end, the Bureau conducts research and provides: (1) a basis for the Nation's physical measurement system, (2) scientitic and technological services for industry and government, (3) a technical basis for equity in trade, and (4) technical services to promote public safety. The Bureau's technical work is performed by the National Measurement Laboratory, the National Engineering Laboratory, and the Institute for Computer Sciences and Technology.

THE NATIONAL MEASUREMENT LABORATORY provides the national system of physical and chemical and materials measurement; coordinates the system with measurement systems of other nations and furnishes essential services leading to accurate and unitorm physical and chemical measurement throughout the Nation's scientific community, industry, and commerce; conducts materials research leading to improved methods of measurement, standards, and data on the properties of materials needed by industry, commerce, educational institutions, and Government; provides advisory and research services to other Government agencies; develops, produces, and distributes Standard Reference Materials; and provides calibration services. The Laboratory consists of the following centers:

\section{Absolute Physical Quantities ${ }^{2}$ - Radiation Research - Chemical Physics - Analytical Chemistry - Materials Science}

THE NATIONAL ENGINEERING LABORATORY provides technology and technical services to the public and private sectors to address national needs and to solve national problems; conducts research in engineering and applied science in support of these efforts; builds and maintains competence in the necessary disciplines required to carry out this research and technical service; develops engineering data and measurement capabilities; provides engineering measurement traceability services; develops test methods and proposes engineering standards and code changes; develops and proposes new engineering practices; and develops and improves mechanisms to transfer results of its research to the ultimate user. The Laboratory consists of the following centers:

Applied Mathematics - Electronics and Electrical Engineering ${ }^{2}$ - Manufacturing Engineering - Building Technology - Fire Research - Chemical Engineering ${ }^{2}$

THE INSTITUTE FOR COMPUTER SCIENCES AND TECHNOLOGY conducts research and provides scientific and technical services to aid Federal agencies in the selection, acquisition, application, and use of computer technology to improve effectiveness and economy in Government operations in accordance with Public Law 89-306 (40 U.S.C. 759), relevant Executive Orders, and other directives; carries out this mission by managing the Federal Information Processing Standards Program, developing Federal ADP standards guidelines, and managing Federal participation in ADP voluntary standardization activities; provides scientific and technological advisory services and assistance to Federal agencies; and provides the technical foundation for computer-related policies of the Federal Government. The Institute consists of the following centers:

Programming Science and Technology-Computer Systems Engineering.

'Headquarters and Laboratories at Gaithersburg, MD, unless otherwise noted; mailing address Washington, DC 20234.

2Some divisions within the center are located at Boulder, CO 80303. 


\section{Evaluation of Construction Loads in Multistory Concrete Buildings}

\section{S. G. Fattal}

Center for Building Technology

National Engineering Laboratory

National Bureau of Standards

Washington, DC 20234

Sponsored by:

The Occupational Safety and Health Administration

U.S. Department of Labor

Washington, DC 20001

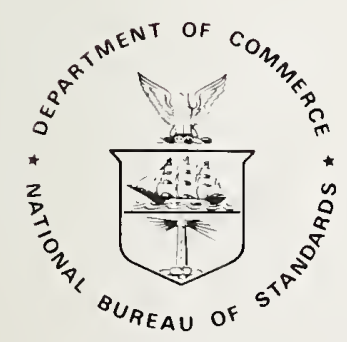

U.S. DEPARTMENT OF COMMERCE, Malcolm Baldrige, Secretary NATIONAL BUREAU OF STANDARDS, Ernest Ambler, Director 
Library of Congress Catalog Card Number: 82-600579

National Bureau of Standards Building Science Series 146

Natl. Bur. Stand. (U.S.), Bldg. Sci. Ser. 146, 139 pages (Feb. 1983)

CODEN: BSSNBV

U.S. GOVERNMENT PRINTING OFFICE

WASHINGTON: 1983

For sale by the Superintendent of Documents, U.S. Government Printing Office, Washington, D.C. 20402 Price $\$ 6.00$

(Add 25 percent for other than U.S. mailing) 
Construction loads in a multistory flat plate concrete building were measured using strain-gaged metal shores and an analog recorder. The instrumented shores were placed within an interior bay of the third story under the formwork for the fourth story floor slab, and loads on the shores were measured continuously over a 24-hour period during the casting and partial curing cycle of that slab. The loads on some of these shores, when subsequently used as reshores in the same bay, were measured during an 8-hour period which included the casting of the fifth story floor slab. A time-lapse camera, operating synchronously with the load data acquisition system, gathered simultaneous photographic evidence of the construction activities during load monitoring periods. This report presents a complete documentation of the field data in compact form for subsequent use in related studies. The load data is interpreted and compared with construction load and design provisions of current standards.

Key Words: concrete buildings; concrete casting; construction loads; construction standards; falsework; field measurements; flat plate; floor slab; formwork; instrumented shores; load measurement; multistory construction; shored construction. 


\section{ACKNOWLEDGEMENTS}

The author expresses his appreciation to the following individuals for their contribution: Tom Ruschell and Frank Rankin made significant contributions towards the execution of the project including the design, assembly, calibration and field testing of the instrumentation package and monitoring construction loads at the site. H.S. Lew provided valuable guidance and critically reviewed the manuscript.

Nick Paleologus, Construction Manager and Larry Munday, Job Supervisor, of Miller and Long Construction Company, provided valuable assistance and cooperation by making all the pertinent information about the structure available to NBS and by facilitating access to, and data acquisition from, the construction site. 


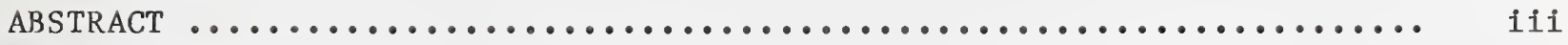

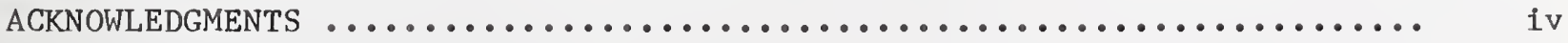

1. INTRODUCTION $\ldots \ldots \ldots \ldots \ldots \ldots \ldots \ldots \ldots \ldots \ldots \ldots \ldots \ldots \ldots \ldots \ldots \ldots \ldots \ldots \ldots . \ldots \ldots \ldots$

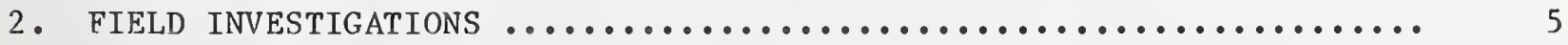

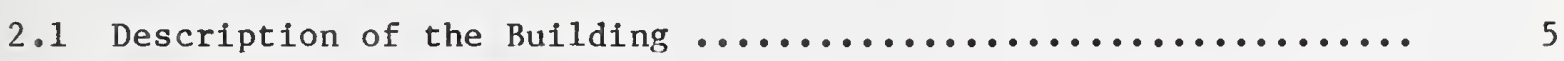

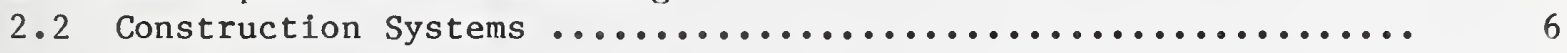

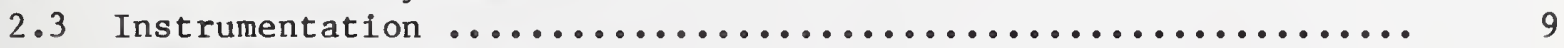

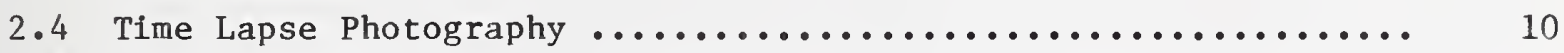

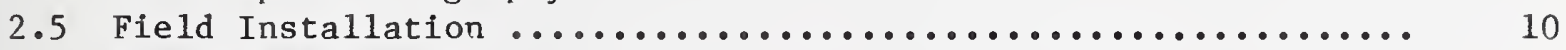

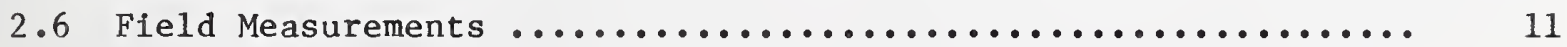

3. REDUCTION OF DATA ................................. 15

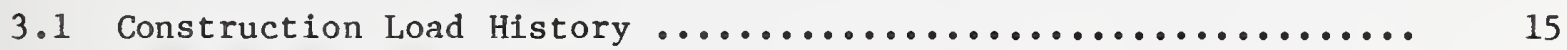

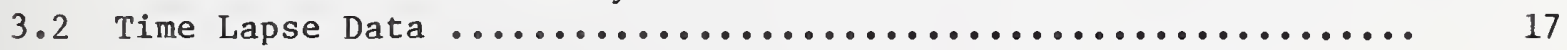

4. ANALYSIS OF DATA .................................... 19

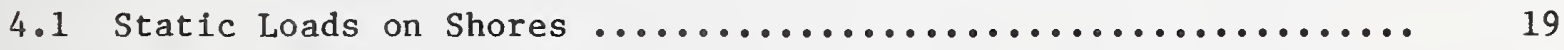

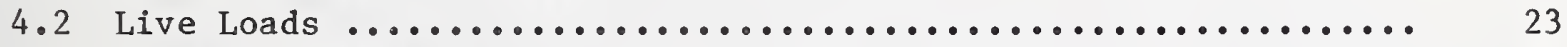

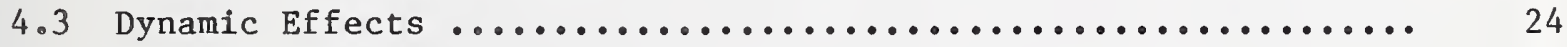

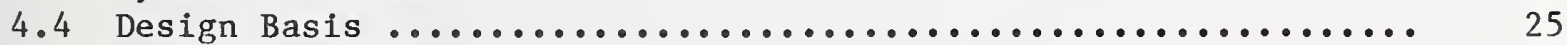

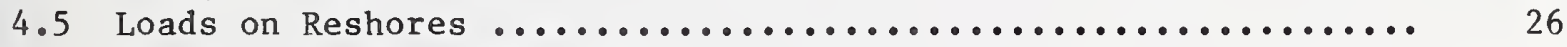

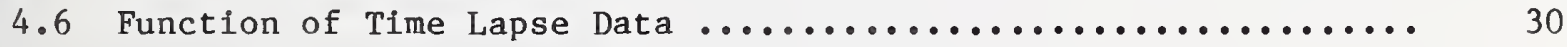

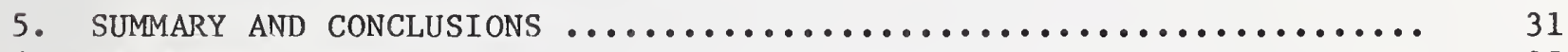

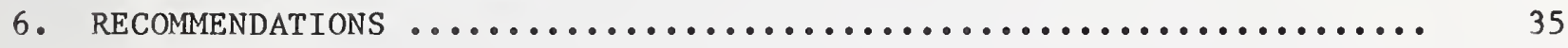

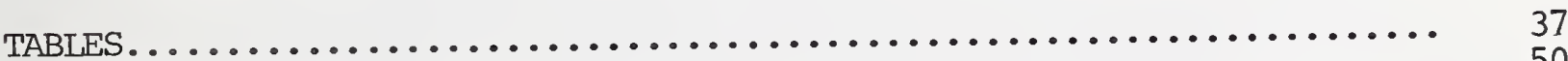

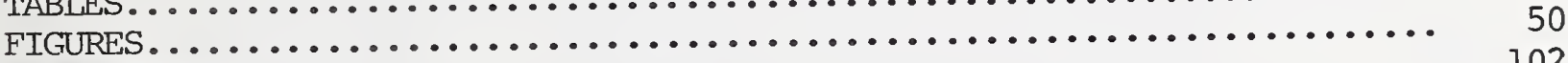

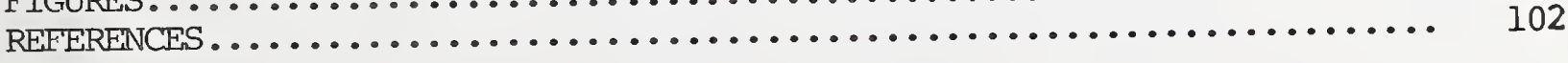

APPENDIX A - Slab Reinforcement Details and Selected Specifications .... A-1 APPENDIX B - Construction Schedule and Concrete Cylinder Test Data ..... B-1 APPENDIX $C$ - Selected Data on Shoring Systems ................... C-1 
Facing page: Placement of concrete in the fifth floor slab. 


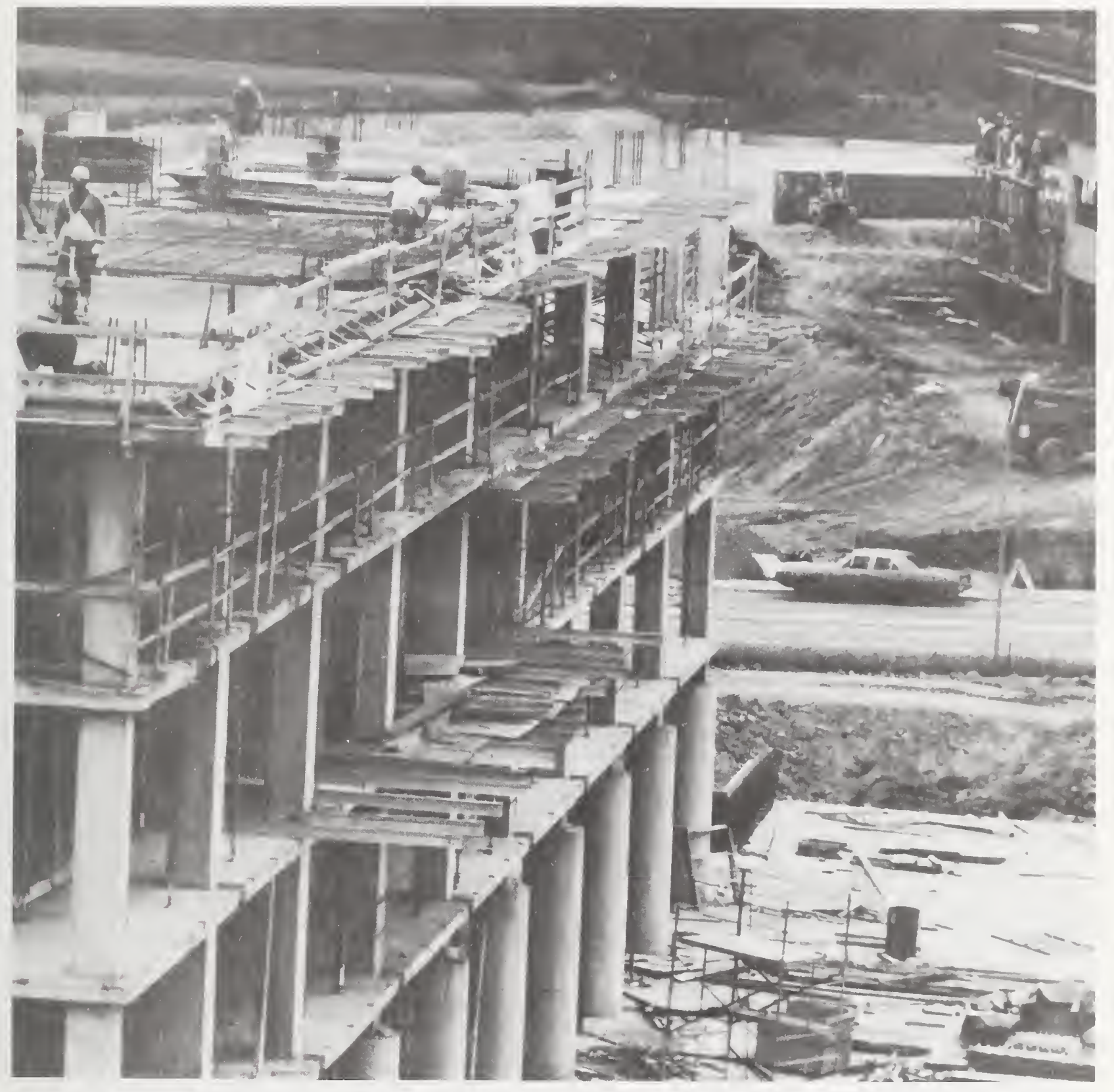

\section{INTRODUCTION}

In multistory flat plate building construction, it is common practice to support the freshly cast slab at a particular floor level by a system of shores extending one or more stories below. The number of stories requiring shores and reshores (shores reinstalled after stripping the formwork) normally depends upon the imposed construction loads, the rate of construction and the strength and stiffness properties of the partially cured concrete. The rate at which concrete matures is, in turn, a function of many parameters such as, curing 
temperature, the properties of its constituents, effect of any admixtures, surface-to-volume ratio and prevailing ambient conditions.

There is no well-defined or generally accepted procedure for determining optimum shoring requirements where the partially erected concrete building is called upon to resist the applied construction loads. The diversity of past practices is illustrated by the 17 different shore-reshore combinations indicated in figure 1.1. The design of a safe and economical shoring scheme is an analytically complex problem which is compounded by the limited amount of available information on construction loads and on the mechanical properties of concrete at early ages [1]*.

The need to develop a reliable data base on construction loads and their effect on partially completed buildings is underscored by the fact that a high percentage of structural failures occur during construction [1]. According to one survey of structural failures over a ten-year period [2], there have been fewer collapses of structures during their service lives as compared to collapses that have occurred during construction. The same source notes that many collapses occur during concrete placing where construction loads have reached a maximum on a structure whose strength is only partially developed.

The problem of shoring in multistory construction has been the topic of analytical investigations by various authors [3-8]. The main thrust of these investigations has been focused on the interaction between falsework and floor slabs under construction loads based on certain assumptions regarding the structural characteristics of the partially cured concrete and the shoring assembly, and the effect of these assumptions on analytical results. More recently, construction loads have been monitored at selected high-rise building sites by means of instrumented shores during the casting cycles of several stories [2, 9, 10, 11]. On the basis of this data, methods have been proposed for predicting construction loads on shored slabs and formulating formwork requirements as a function of type of cement, placing temperature and rate of construction.

This report describes the evaluation of construction loads at the site of a 6 -story flat plate office building. The equipment used in this investigation consisted of metal shores instrumented with strain gages and hard wired through signal-conditioning amplifiers to a multi-channel tape recorder housed in a mobile van adjacent to the structure. The building is nine bays long and six bays wide and all bays are $20 \mathrm{ft}(6.1 \mathrm{~m})$ square except in the interior core region where their spans vary. Each floor slab was cast in four consecutive transverse sections in as many days, so that allowing for the placement of columns, reinforcement and falsework, the construction progressed at the rate of about one floor per calendar week.

* Number in brackets refer to the bibliography listed at the end of this report. 
The instrumented shores were placed within an interior bay of the first section at the third floor level. The loads on the shores were monitored during a 24hour period, the first six hours of which was approximately the time $1 t$ took to cast the first section of the fourth story floor slab. Some of the instrumented shores were subsequently used as reshores in the same bay following the removal of formwork. The loads on these reshores were monitored over an 8-hour period which included the casting of the first section of the fifth story floor slab.

During these casting operations, the construction activities were monitored by an automatic time-lapse camera beamed on the work area. The camera was placed on the roof of an adjacent bullding and operated at four second intervals. The purpose of the camera was to identify the source, nature and time of occurrence of construction loads for later comparison with the measured loads. The camera also provided the type of visual information which can be examined to determine the feasibility of estimating construction loads by means of time-lapse photography alone.

The load data gathered in the field are presented in this report in the form of continuous plots of the individual shore loads as a function of time. The plots were developed using a strip chart recorder. Some of these plots show markings along the time scale that represent points in time when concrete was discharged from the bucket onto the deck. These markings were established by examining the films taken by the time-lapse camera.

The loading on the shores and reshores obtained in the field is analyzed and compared with the corresponding design provisions in current codes and standards. Based on these comparisons, conclusions are drawn on the adequacy of existing load provisions in the design of falsework systems used in concrete building construction.

The material documented in this report provides a data source for static and dynamic load effects in shored concrete construction. In addition, it provides information useful in the development of a generally applicable methodology for the evaluation of construction loads and their effects on the partially completed structure under diverse types of field conditions. Therefore, the methodology use in this particular study is described in all its aspects, including concrete cylinder test results, the construction sequence and pertinent information on the structural characteristics of the building and the shoring system. 
Facing page: Calibration of instrumented frame shores in the Zaboratory. 


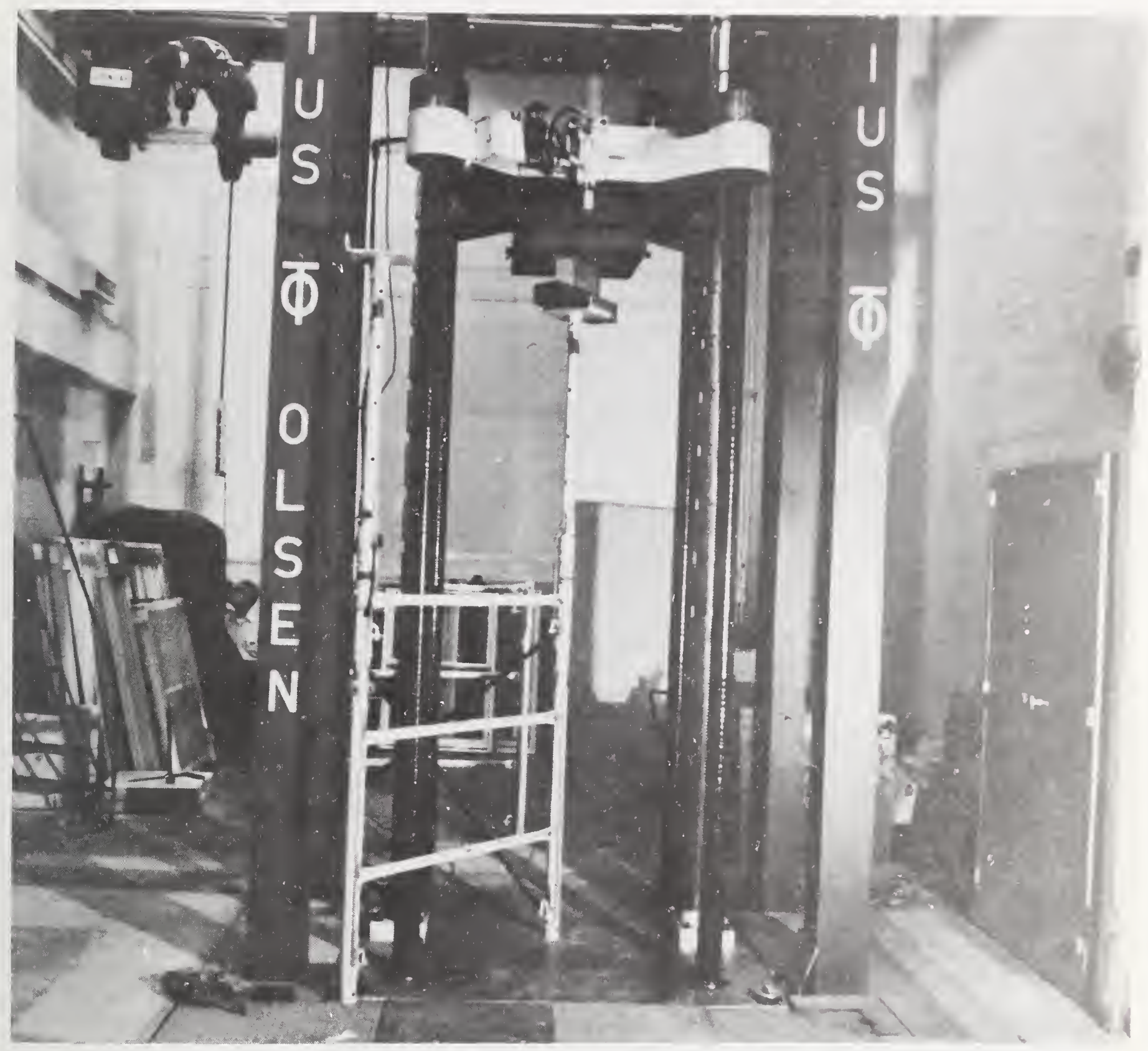

2. FIELD INVESTIGATIONS

\subsection{DESCRIPTION OF THE BUILDING}

The building selected for this study is a six-story concrete flat plate structure intended for commercial use. A typical floor plan for the second through sixth stories is shown in figure 2.1. All bays are 20 feet (6.1 m) square except in the service core area which has the framing plan shown in figure 2.2 . 
The story heights are specified on a longitudinal section through the core area shown in figure 2.3. Figures 2.4 and 2.5 are respective views of the east and south sides of the building during construction of the fifth story floor slab. The above-grade portion of the building consists of nine longitudinal bays, in the north-south orientation, and six transverse bays. The parking garage is the story below grade level which extends three additional bays beyond the tower at the south and east sides, and is accessed by a ramp along the north side. Information above the fifth story floor slab is not included in this report because that portion of the building was not yet in place at the time the field investigations were concluded.

The design specifications call for 3000 psi (20.70 MPa) regular weight (150 pcf or $2400 \mathrm{~kg} / \mathrm{m}^{3}$ ) concrete, 8-in (203-mm) thick floor slabs, and design live loads of $80 \mathrm{psf}(3.8 \mathrm{kPa})$ plus $20 \mathrm{psf}(960 \mathrm{~Pa})$ for partitions in the office area (figure 2.3), and $100 \mathrm{psf}(4.79 \mathrm{kPa})$ for the stairs. Supplementary details for the reinforcement in a typical floor slab and selected structural specifications excerpted from the contract drawings are found in appendix A.

\subsection{CONSTRUCTION SYSTEM}

The falsework for the construction of the floors in the tower section consists of 5/8-in (15.875-mm) plywood forms laid across aluminum joists spaced at 19.2 in $(488 \mathrm{~mm})$ on center. The joists are supported by aluminum stringers spaced at approximately $10 \mathrm{ft}(3.05 \mathrm{~m})$ on center in the orthogonal direction. The

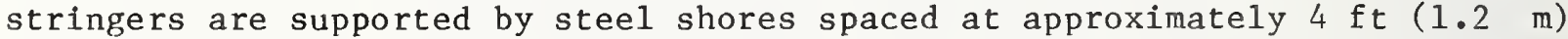
on center along the stringers. The shores bear against the concrete floor directly below the floor to be cast. Figure 2.6 is a partial view of the shoring system below the second floor slab, which also appears in figure 2.7 in the background. The portion of the floor shown in the foreground of figure 2.7 has already been stripped of formwork and reshored.

The detailed sequence of construction is documented in table B.1 of appendix B. This information was assembled from the job superintendent's daily construction log files. By scanning through table B.l, the shoring sequence for casting the consecutive floor slabs can be established.

The slab-on-ground ( $S O G$ ) is cast first. This is at the basement level, a full story below finished grade (figure 2.3). It should be noted that the foundation slab is cast in seven sections proceeding from south toward north. This scheme allows operations for framing of falsework, casting of columns, placement of steel bars for the slab above, and other construction activities to proceed while the placement of the foundation slab is still in progress.

The first story floor slab, which is at grade level, is cast in ten sections. Thereafter, each consecutive floor is cast in four sections in as many working days, which are usually consecutive. The sections are cast in the numerical sequence indicated in figure 2.1 which also defines their respective areas. This scheme allows construction to proceed at a maximum rate of approximately 
one complete floor per calendar week. Therefore, the slab directly below the floor section being cast is seven (or more) days old.

It is noted from table B.1, that section 1 of floor 2 was cast on May 5. At that time, the formwork for sections 1 through 5 of floor 1 , which include the area under section 1 of floor 2, had been already stripped and reshored. This practice of stripping and reshoring before casting the same section at the next level was followed throughout the construction of the building.

Figure 2.8 shows the concrete casting schedule for the slabs up to the point when casting of section 2 of floor 5 was completed. The numbers without parentheses indicate casting dates of the various floor slab sections. The number within parentheses designate the dates when the formwork below the various sections was stripped and reshores installed. Note that stripping of formwork for the second and third floors occurred typically seven calendar days, and for the fourth floor six calendars days, after casting, indicating an accelerating trend of construction. A similar trend is observed in the time interval between the casting of the same section in consecutive floors. The interval for the second to fourth floors varied between eight to 13 days while that for the fourth to fifth floor was reduced to seven days.

The criterion used in this job for stripping the formwork was that the concrete in the slab should attain a minimum strength of 2250 psi (15.52 MPa), which is 75 percent of the specified 28-day compressive strength: $\mathrm{fc}^{\prime}=3000 \mathrm{psi}$ $(20.70 \mathrm{MPa})$. This required testing of control specimens at early ages corresponding to the time interval between casting and stripping of the various sections. Table B.2 shows concrete cylinder test results at 5,7 and 28 days along with other control data which were part of the job superintendent's record.

For this building, the minimum number of shored and reshored stories at any given time is specified as one and three, respectively. This means the first time any reshores could be removed was after casting the fourth floor and before casting the fifth floor. Figure 2.8 specifies the date, shown in brackets, where the basement reshores in section 1 were removed; it should be noted that this operation was carried out before casting section 1 of the fifth floor but after section 1 of the fourth floor and the reshores below it were in place. This procedure was followed during the construction of the rest of the building.

The shoring sequence and forming requirements for typical floor areas specified in the contract documents are reproduced in figures 2.9 and 2.10 . From the standpoint of evaluating the distribution of construction loads to the floors below, two additional aspects of the shoring operations need to be highlighted; the method used for simultaneous stripping of formwork and installing reshores, and the number of reshores used. Both of these are spelled out in the specifications shown in figure 2.9. In the first case, the first step is to install the reshores directly against the plywood forms. This is followed by the removal of the existing shores, stringers and joists, thereby transferring the loads from the slab above to the reshores. The last step is to remove one 
reshore at a time, strip the form above it and reinstall the reshore (figure 2.9).

In the second case, the specified reshoring scheme after stripping the formwork is illustrated in figure 2.10. This is referred to as the 100 percent reshoring plan, according to which, eight reshores are installed for every ten shores removed. Thus, when a story is reshored, there will be three additional shored stories below it, assuming enough stories have been completed. However, in accordance with the shoring requirements (figure 2.9 ), only the top two stories will conform to the 100 percent shoring plan. The lower two shored stories will conform to the 75 percent reshoring plan as illustrated in figure 2.10. As noted above, the reshores from the lowest story (75 percent reshores) are removed before casting the next floor.

The shoring specifications in the contract documents (figure 2.9) make reference to an independent set of documents for the design and installation of the shoring system. The shoring scheme for a typical floor (third through sixth floors) is shown in figure 2.11, which was excerpted from the referenced documents. A typical shoring profile outside the core region (section A-A, figure 2.11) is shown in figure 2.12 .

From figures 2.11 and 2.12 the following will be noted. The same aluminum beam section is used for both the stringers and the joists. They are typically 21 ft $(6.4 \mathrm{~m})$ long except some of the joists, used between columns or in the core region, are shorter ( $16 \mathrm{ft}$ or $12 \mathrm{ft} ; 4.9 \mathrm{~m}$ or $3.7 \mathrm{~m}$ ). Since the spacing between shore legs is about $4 \mathrm{ft}(1.2 \mathrm{~m})$, the stringers are continuous over six supports as shown in figure 2.12. They are overlapped about $5 \mathrm{ft}\left(\begin{array}{lll}1.5 & \mathrm{~m}\end{array}\right)$ over two adjacent shore legs (figure 2.12). In the case of the joist supports, because the stringers are approximately $10 \mathrm{ft}(3.1 \mathrm{~m})$ on center, the $21 \mathrm{ft}$ $(6.4 \mathrm{~m})$ joists are continuous over three stringer supports with a typical overlap of $1 \mathrm{ft}(0.3 \mathrm{~m})$. The aluminum beam is actually a composite section having a U-shaped top flange which integrates a square wood section for the purpose of nailing the plywood forms to the joists. Hereafter, this beam will be referred to as the "Aluma beam" which in the term used by the supplier.* The sectional and structural properties of the bean are found in appendix $C$.

Several types of shores were utilized in the construction of this building. Appendix C identifies, and provides details for, each of the types. The heavy duty steel single post shore was mainly used for the purpose of reshoring the second story floor slab. Two of these shores (with round perforations) may be seen in figure 2.7. The steel single post shore was used as a shore as well as reshore in above-ground stories. The nominal $4 \times 4$ in (100 x $100 \mathrm{~mm}$ ) wood post, which was assembled from two $4 \times 4$ sections jointed by two Ellis* type

* The United States Government does not endorse products or manufacturers. Trade or manufacturers' names appear herein only because they are considered essential to the object of this document. 
clamps, were used mostly as reshores. The frame-type steel shore, consisting of two legs and three horizontal cross-bars, were used as shores in the aboveground stories. It was also used for the purpose of shoring and reshoring the first story in the stacked mode combination with a frame shore having four horizontal crossbars. Several of these stacks of frames can be seen in figure 2.7. The hardware attachments for the metal shores are identified in appendix $C$, along with material and structural properties of the miscellaneous shores, and test data for the frame shores.

\subsection{INSTRUMENTATION}

Three frame shores, of the type with three cross-bars, and five single post shores were instrumented with electrical resistance strain gages and calibrated in the laboratory for use as construction load transducers in the field. Thus, a total of eleven shore legs were instrumented.

The instrumentation for each shore leg consisted of four $1 / 4-$ in $(6.35-\mathrm{mm})$ strain gages of identical stock mounted at the sane longitudinal location and at 90 degrees to one another around the circunference. Two of the gages were installed in the direction of the shore axis, and on diametrically opposite faces, to compensate for flexural effects. The other two gages were also installed on two diametrically opposite faces but were oriented at 90 degrees with respect to the axis of the post. The gages were protected with neoprene rubber padding to protect them from accidental damage in the field.

The single post shores were calibrated individually in a universal testing machine. They were loaded to $10 \mathrm{kips}(44.5 \mathrm{kN})$ and then unloaded four consecutive times. The strain gage output signals under a $6 \mathrm{~V}$ bridge excitation were recorded at 2-kip $(8.9 \mathrm{kN})$ load intervals during the four loading-unloading cycles.

The frame shores were calibrated in two different ways. First, each shore column was calibrated as above (figure 2.13). Next, the frame was loaded centrally via a cross-beam (figure 2.14) and calibrated as above except a 20-kip $(89 \mathrm{kN})$ peak load was used in this case.

The calibration factors for the individual shores are listed in table 2.1. They were calculated by averaging the replicate results. In all cases they turned out to be constant, indicating a linear response within the range of the applied loads. However, the factors for the frame columns, when loaded individually, were, in most cases, slightly different from those obtained by simultaneous loading, the biggest difference being about 2.4 percent. The differences may be attributed to the flexural effect of the top cross-beam ledger of the frame when the columns are loaded individually (the gages were mounted below the top cross-beams, figures 2.13 and 2.14).

It was estimated that the peak load that a shore column will experience in the field would be in the neighborhood of $5 \mathrm{kips}(22 \mathrm{kN})$, or $7.5 \mathrm{kips}(33.4 \mathrm{kN})$ if an allowance is made for a 50 percent dynamic load factor. This corresponds to a 
maximum (unconditioned) transducer output signal of approximately $2 \mathrm{mV}$, based on the calibration factors specified in table 2.1. Assuming further that a 1 percent resolution is desired, the recorder should be able to sense any load fluctuation greater than 1 percent (corresponding to a transducer signal of $20 \mu \mathrm{V}$ ) of the estimated peak shore load.

Such low signals are unrealistic to expect under field conditions where the potential noise may be several times greater. The proximity of a transmission tower to the site was an additional concern. Consequently, it was decided that the signals from the transducers should be amplified close to the source before they are transported via cables to the recording device, which, in this case, was located about $120 \mathrm{ft}(36 \mathrm{~m})$ away from the source.

The signals from 11 load channels were conditioned independently by as many amplifiers. A full range output setting of $10 \mathrm{~V}$ was used for a $2 \mathrm{mV}$ input signal resulting in an amplification ratio of about 5000 to 1 . The exact gain of each amplifier obtained by individual calibration before use in the field is given in table 2.1. The last column of this table gives the calibration factors for the amplified signals from the eleven transducers.

The last basic component of the data acquisition system was a multi-channel analog tape recorder which received the 11 amplified signals via 120-ft (36-m) cables. A twelfth channel was utilized in conjunction with a digital time code generator to relate the continuously recorded signals from the individual channels to a real time frame.

\subsection{TIME LAPSE PHOTOGRAPHY}

An automatic time lapse camera was used for the purpose of gathering photographic evidence of construction activities during load monitoring periods. The camera provided a visual means by which live loads of equipment and personnel could be identified and uncoupled from the dead load of freshly cast concrete. In addition, it simplified the interpretation of dynamic load effects by identifying their source and nature.

The camera was battery powered and was equipped to operate at settings of one frame per 0.5 to 99.5 seconds in 0.5 -second intervals as well as at 16 frames per second, which is the standard setting of a movie camera. Other features included weather resistant housing, automatic exposure control, an $\mathrm{f} / 1.2$ zoom lens, super $8 \mathrm{~mm}$ format cartridge loading, and a film footage counter. The installation and use of the camera in the field is described in the next section.

\subsection{FIELD INSTALLATION}

The actual shoring layout in the first section of a typical story is shown in figure 2.15. Note that this layout is slightly different from the original shoring plan shown in figure 2.11 . 
After calibration, the instrumented shores were delivered to the job supervisor for use as part of the shoring in the first section of the third story. When this shoring was being installed, no special instructions were given to the workers regarding the placement of the instrumented shores other than specifying their location within the overall shoring scheme used. The intent behind this omission was to develop a feel about possible fluctuations in shore preloads, due to differences in snugness after they are in place, that might be reflected in the results of subsequent measurements of shore loads.

Figure 2.15 indicates the location and numerical order of the instrurnented shores. They were all placed within a single bay, identified in the figure by the solid square columns. This area represents a typical interior bay away from the core region.

The procedure for installing the falsework was as follows. The frames were erected first in braced pairs to form free-standing towers (figure 2.15). Next, the stringers were placed in the U-shaped shore heads parallel to the frames and levelled by adjusting the telescoping staff heigths. The single post shores were then erected snug against the stringers and the Aluma joists were placed on top of and across the stringers. The $4 \times 8 \mathrm{ft}(1.2 \times 2.4 \mathrm{~m})$ forms were then tightly fitted and nailed to the joists with the face grain of the forms running across the joists. Finally, the formwork was levelled by making the necessary fine adjustments in the shore heights.

The data acquisition equipment was installed after the falsework was in place and the area cleared of workers and materials. To keep the length of transducer lead wires to a minimum (within $15 \mathrm{ft}$ or $4.6 \mathrm{~m}$ ), the amplifiers were placed as close as possible to the instrumented shores. They were mounted on racks and housed in an enclosed metal container equipped with an intake fan (figure 2.16). The lead cables from the amplifiers were bundled and lowered over the edge of the slab (figure 2.17) into a mobile van near the south side of the building (figure 2.18) where they were attached to an analog recorder housed in the van.

The time lapse camera was mounted on an adjustable tripod placed on the roof of a six-story structure on the south side of the building (figure 2.19 and 2.20). This was not the best location for the camera because the inclination of the lens axis from horizontal was in the 6 to 9 degree range when beamed on the work area. A 45-degree inclination would have been preferable because it would have offered a better perspective of both horizontal distances and heights. However, there were no other surrounding buildings and mounting the camera on the crane tower or on a work platform would have possibly subjected it to excessive movement or interfered with the construction work. In this respect the remoteness of the camera $(250 \mathrm{ft}$ or $76 \mathrm{~m}$ ) from the work area was an advantage.

\subsection{FIELD MEASUREMENTS}

Figure 2.22 shows the framing plan of the shoring system in the third story for a 3-bay square area in which the center bay contains the instrumented shores. 
The location of each shore in this region was established by means of independent tape measurements. The coordinates of the second and first story reshores for the same region were obtained in a similar manner. These are shown in figure 2.23 and 2.24 , respectively. Note that the number of reshores in the second and first stories correspond, respectively, to the 100 and 75 percent shoring schemes shown in figure 2.10.

Table 2.2 presents a summary of the time sequence of field investigations carried out over a 24-hour period starting with the placement of concrete in the first section of the fouth story floor slab. At this site, a crane was used to deliver concrete to the deck in a 2 cubic-yard ( $1.53 \mathrm{rn}^{3}$ ) capacity bucket. Figure 2.25 shows the loaded bucket being lifted off the ground on the west side. The crane tower, located within an exterior bay (fifth bay from the south side), is seen in figure 2.26 .

The placement of concrete in the first section proceeded from east to west at the rate of about $2 / 3$ cubic yard $\left(1 / 2 \mathrm{~m}^{3}\right.$ ) per minute (or at 3 minute intervals between deliveries). Since this section requires about 150 cubic yard (115 $\mathrm{m}^{3}$ ) of concrete, it would take approximately 4 hours and 75 deliveries to complete the job. The actual figures were about the same: $33 / 4$ hours (table 2.2 ) and 82 deliveries (chapter 3 ).

The first bucket was delivered at 8:00 a.m. (table 2.2). The data acquisition system was set up 2 hours before that but because of a power interruption, the first calibration was completed at 8:56 a.m., or about one hour after casting began. Thereafter, the amplified signals from the eleven shore transducers and the time code generator were recorded on tape at a speed of 15/16 ips $(23.8 \mathrm{~mm} / \mathrm{s}$ ) continuously (except for short interruptions for calibration or to change the tape) until $8: 30 \mathrm{a} \cdot \mathrm{m}$. the following morning. The system was calibrated at the beginning and end of each of the two tapes used, and at intervals varying between two to five hours. The need for and frequency of these calibrations were based on earlier checks of tape recorder drift during miscellaneous field tests of the data acquisition system. All calibrations were made at zero and $5 \mathrm{~V}$ amplifier output levels.

During recording, the amplifier output signals were visually monitored on an oscilloscope equipped with a cathode ray tube. The time code generated signal was also monitored visually on a digital clock which was synchronized with an electric clock mounted on an exterior shore (figure 2.21).

The time lapse camera took frames at 4-second intervals during the period $7: 20 \mathrm{a} . \mathrm{m}$. to $3: 25 \mathrm{p.m}$., with one 5-minute interruption to replace the cartridge. In order to capture sufficient detail, the camera was kept zoomed upon the work area where concrete was being cast by rotating it manually on three different occasions as casting progressed from east to west. The clock came in view only during the two intermediate orientations of the camera. However, this was not a major drawback because the clock was used primarily for convenience and as an approximate check of the clock mechanism of the camera. 
When the third story was reshored six days later, the five instrumented shores and two of the instrumented frames were reinstalled in the same bay as reshores. Figure 2.27 shows their layout within the same 9-bay region shown in figure 2.22 . As before, the coordinates of all the reshores in this region were obtained by independent measurements.

The loads on the instrumented reshores were recorded during the casting of the first section of the fifth floor slab. This occurred the day after the third story was reshored. The set-up and field investigations were the same as before. The duration, however, was shorter as indicated in table 2.3. The data acquisition system was disconnected before casting was completed. Actually, most of the slab was cast before 12:00 noon; there were only four more bucket deliveries in the afternoon. The time lapse camera, however, kept operating until after the casting had been completed. This marked the end of the field investigations. 
Facing page: Framing and shoring layout below formwork of fifth floor slab. 


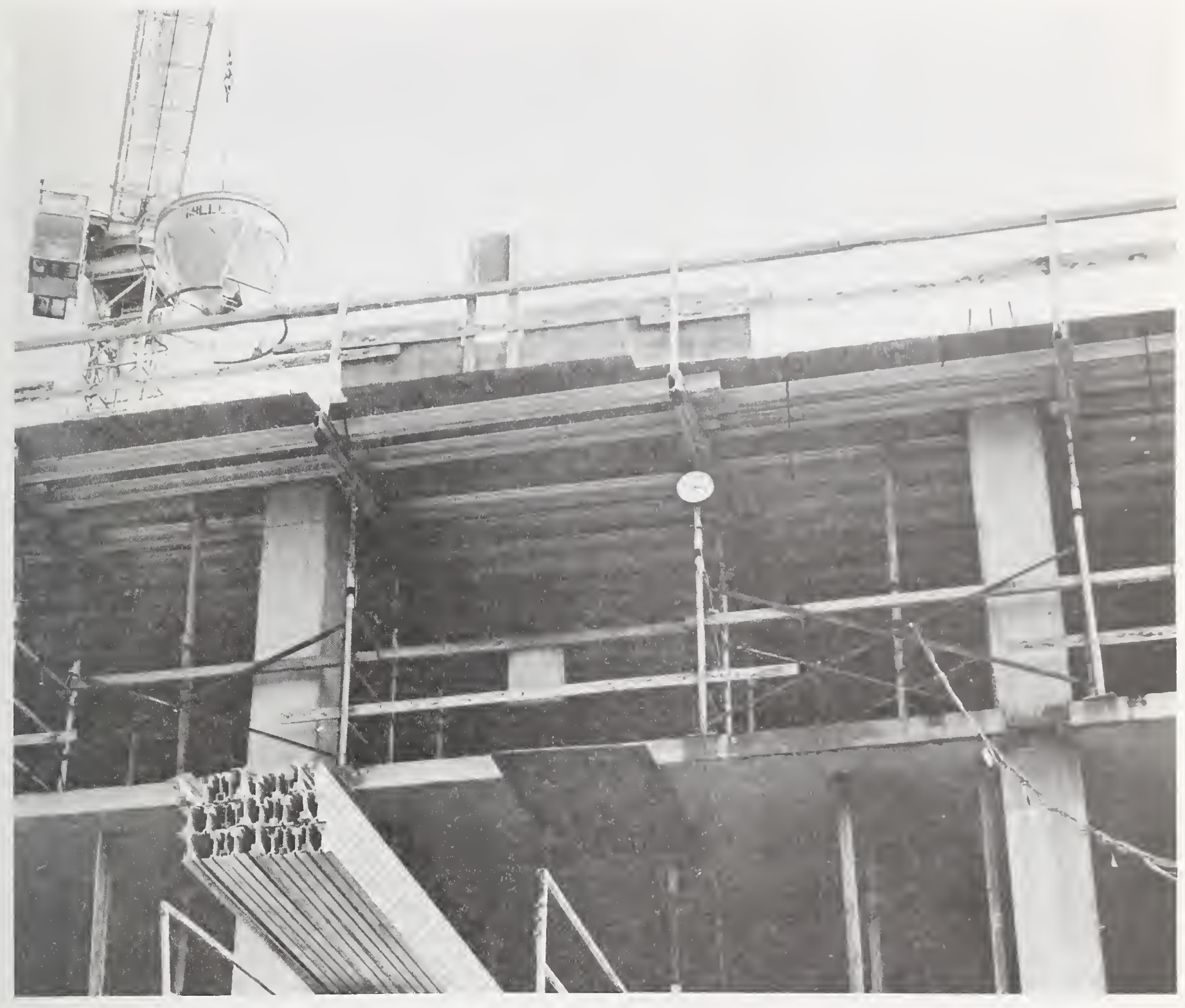

3. REDUCTION OF DATA

\subsection{CONSTRUCTION LOAD HISTORY}

It will be recalled that a total of three tapes were required to gather construction load data. For convenience, these tapes will be identified by numbers in the chronological sequence they were used. Tapes 1 and 2 contain shore load data over a 24-hour period starting with the casting of the fourth story floor slab. Tape 3 contains load data for the reshores used in the third story during the casting period of the fifth floor slab a week later. 
The channel numbers on the tapes are consistent with the numbering sequence for shores and reshores appearing in figures 2.22 and 2.27 , respectively. For clarity, a frame-type shore column will be referred to simply as a shore or reshore, depending on its function.

The field data is reproduced in the form of plots of the individual load channel outputs against time using a strip chart recorder. The plots in figure 3.1 through 3.6 represent the data for shores 1 through 11 contained on tape 1. The full range of the strip chart paper represents a $10 \mathrm{~V}$ tape signal (20V in the case of channel 10). The three intermediate calibrations at 0 and $5 \mathrm{~V}$ levels appear in each of these plots. Although the initial and final calibrations are not reproduced, they were used, along with the intermediate calibrations, to make the appropriate corrections for drift. This explains the slightly oblique abscissae appearing in some of the plots. The ordinates were converted to load units on the basis of the calibration factors shown in the last column of table 2.1 .

It was mentioned earlier that casting started about one hour before the first calibration was completed. However, during that interval, the instrumented shores experienced only minimal loads because the bays being loaded were remote from that area and no other unusual loads were witnessed by the camera. The development of shore loads occurred mostly during the time interval 9:00 to 10:30. The time scale in figures 3.1 through 3.6 is too compressed to allow an adequate study of this transition stage.

Figures 3.7 through 3.12 were developed for that purpose. They represent partial shore load histories in the interval 9:00 to 10:30 a.m. on an expanded time scale. The points in time when concrete was discharged from the bucket onto the deck are indicated by numbered points along the time axis. This information was obtained by examining the films of casting activities taken by the time lapse camera. The points were rounded to the nearest minute and are plotted as such. This explains why, in some cases, sudden jumps in shore loads do not coincide exactly with the plotted points.

The time scale of the latter set of curves is still too compressed to exhibit fully the dynamic nature of transient loads when concrete is discharged. The inserts, however, serve that purpose. They are displayed at a selected number of locations where the curves are too steep to be distinguishable from vertical. The inserts were developed using the same scale for the ordinates as the parent curves and expanding the time scale by a factor of 20 .

Shore load histories for the second half of the 24-hour period are exhibited in figures 3.13 through 3.18. They were developed from information contained on tape 2. Since the time lapse camera was not used during this period, the source of sharp fluctuations observed in most of the plots starting just before 7:00 a.m. is not known. This was about the time when the construction crew resumed work on the deck to proceed with the placement of concrete in the next section (section 2, figure 2.11) of the fourth floor slab. The inserts in 
figures $3.15,3.17$ and 3.18 , where the time scale is expanded by a factor of 320 , indicate the dynamic nature of load fluctuations in some of the shores.

The data on reshore loads were reproduced in the same manner as above. First, the entire contents of tape 3 were plotted on a compressed time scale as shown in figures 3.19 through 3.23. The reshore loads were then replotted using an expanded time scale for the period 9:00 to 10:30 a.m. to show the development of loads more clearly. The resulting plots are shown in figures 3.24 through 3.28 , together with a selected number of inserts at locations where sudden changes in ordinates are indicated. Note that these changes coincide with the various discharges of concrete represented by consecutively numbered points along the time axis.

\subsection{TIME LAPSE DATA}

Time lapse photography provided a means by which the source, nature and time of ocurrence of construction loads could be identified and related to measured loads. The results obtained by analysis of the time lapse films are presented in the form of diagrams and tables.

Table 3.1 compiles time lapse data obtained on the day shore load measurements were made. The frame numbers and corresponding real time listed in the first two columns provide the time reference for the construction events identified in the last column. The events listed are those associated with a principal source of loading. They include the 82 pours cornpising the fourth floor slab, instances of maximum number of people found in one bay, and instances of superimposed materials on the newly completed slab. The third column specifies the time it took to discharge concrete from the bucket for the various pours assuming it to be equal to the number of frames times the 4-second time lapse interval used. Column 4 specifies the height of pour estimated by using, as visual human scale, the worker operating the lever arm controlling the flow of concrete from the bucket. For that purpose, the worker's anthropomorphics were assumed that of the 95 th percentile U.S. adult male subject [14]. The multiple entries in this column match the corresponding numbers of exposures in the first column. Casting events numbers 26 through 50 appear in the partial shore load history plots shown in figures 3.7 through 3.12 .

Table 3.2 compiles time lapse data obtained on the day reshore loads were measured. This table is similar to table 3.2 in format and type of content and needs no further comments. Casting events 31 through 55 appear in the partial reshore load history plots shown in figures 3.24 through 3.28 .

In addition to the foregoing information, examination of the time lapse films identified approximately the areas occupied by the various pours. Figures 3.29 and 3.30 superimpose the areas occupied by the pours in the fourth and fifth story floor slabs, respectively, on the third story shoring plan, which typifies the fourth story shoring plan as well. The arrows in these figures represent the general direction of travel of the bucket during the discharge of concrete. 
Facing page: Layout of reinforcement in floor slab prior to casting. 


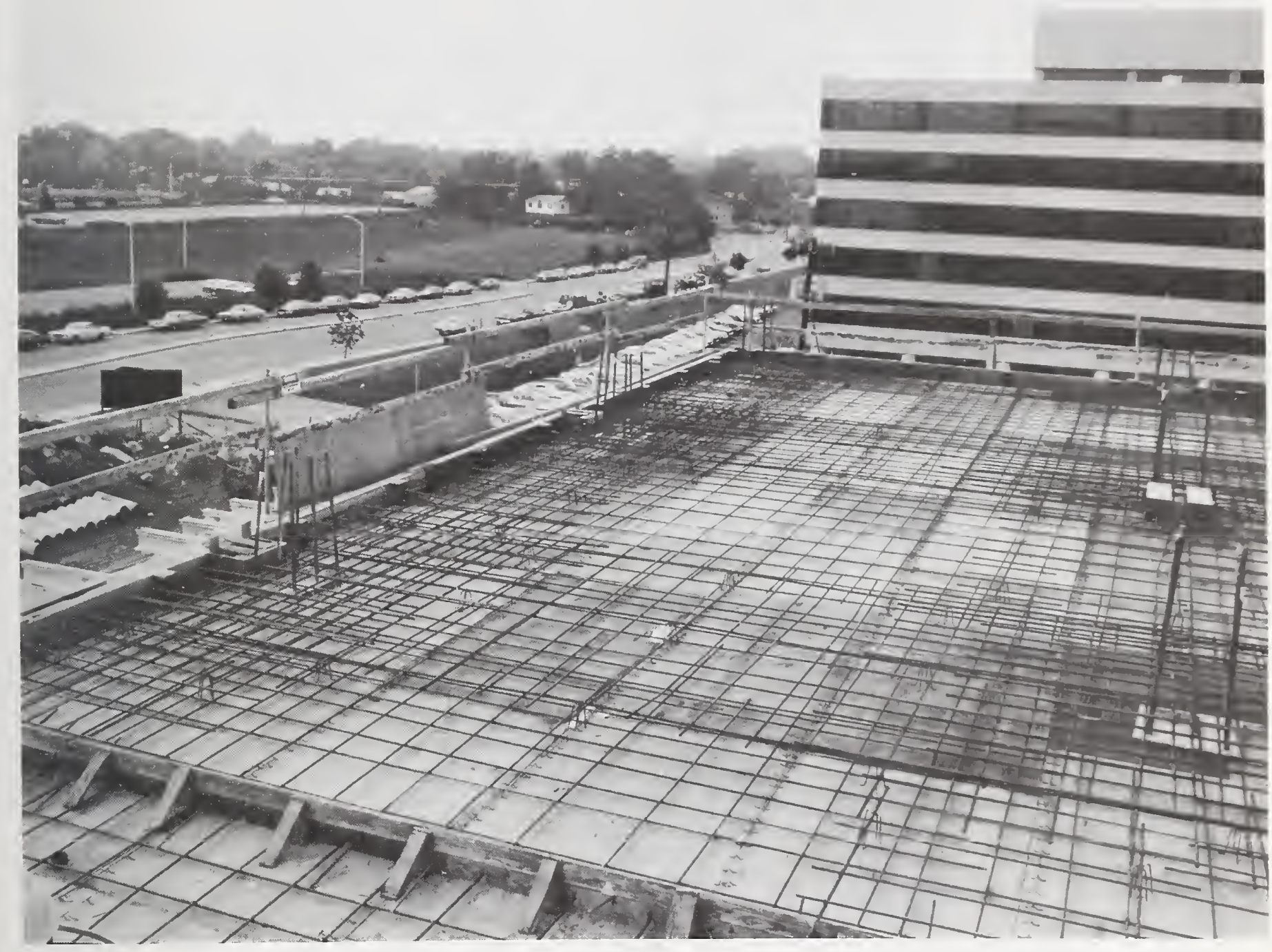

\section{ANALYS IS OF DATA}

\subsection{STATIC LOADS ON SHORES}

The general trend of shore loads over the 24-hour measurement period may be examined by reference to the two sets of plots shown in figures $3.1-3.6$ and 3.13-3.18. It should be kept in mind that the measured loads represent, in addition to the weight of the concrete, loads which are transient in nature, such as effects produced by impact or the weight of construction equipment, materials and personnel. On the other hand, the weight of the falsework, 
reinforcing bars and any initial precompression in the shores, will not appear as part of the load data.

Because the load-history plots include effects from more than one source, it is important to distinguish loads attributed to the weight of the concrete, herein referred to as "static loads" for convenience, from those which are transient in nature. According to the load-history plots, the static loads were almost fully developed by 10:30 a.m., or shortly after the 50th pour was completed (see figures $3.7-3.12$ ). This is understandable because, according to figure 3.29 , casting had progressed well beyond the bay where the instrumented shores were located. Thereafter, the loads on most shores kept increasing somewhat, reached their respective peaks during the time interval 6:00 - 8:00 p.m., then decreased gradually until 6:48 a.m. the following day (see lower insert, figure 3.18). The period between $6: 48$ and 8:00 a.m., when load measurements were terminated, is marked with sharp load fluctuations which were particularly significant in the case of shore 11. The cause of these disturbances is not known with certainty because there is no photographic evidence of construction activities which were known to have resumed at the beginning of that period.

Table 4.1 has been prepared to simplify comparison of static shore loads occurring at specific points or periods in time. The first set of load data (appearing in the second column) represents the static components of shore loads at 11:43 a.m., which is the time when casting had just been completed (see table 3.1). This was the earliest time where the area in the vicinity of the instrumented shores became and remained free of objects and workers.

The next two columns in table 4.1 represent, respectively, the maximum static loads, occurring between $6: 00$ and 8:00 p.m., and those occurring at 6:48 a.m. the following day, or just before construction work was resumed. The column labelled "tributary loads" are static loads on the shores calculated according to the tributary areas shown in figure 4.1(a). The entries in the column labelled "distributed loads" were obtained by analysis, taking into consideration the structural response of the Aluma joists and stringers based on the gridwork layout shown in figure 4.1(b). The sectional and material properties of the Aluma beams are specified in appendix $C$.

The last column of table 4.1 represents the incremental static loads due to the combined weight of the fornwork, reinforcing bars, Aluma beams and the shores, expressed in units of distributed loads per unit floor area, as follows:

\section{psf ( $\mathrm{Pa})$}

3/4-in (19-mm) plywood formwork: 
The total incremental static load of 9.7 psf $(465 \mathrm{~Pa}$ ) represents 9.7 percent of the 100-psf $(4.79 \mathrm{kPa})$ static load due to the weight of the concrete. Thus, the incremental loads on the shores were estimated by multiplying the distributed static loads by a factor of 0.097 .

Referring to figure $4.1(\mathrm{~b})$, it is noted that the Aluma joists are laid out in the east-west direction and span over three stringer or shore lines in the north-south direction. The joists coming into the bay overlap at the middle shure line (shores 3,8,9\&5) and are continuous over the outer shore lines (shores 2, 6, 7 and $4,10,11$ ). As a result of this layout, the middle line of stringers (within the middle strip) receive only 60 percent of the loads transmitted to the outer lines of stringers (within the column strips), with one exception. The two joists spanning along column lines 8 and 9 , respectively, transmit more loads to the middle line than to the outer line of stringers.

The distributed loads in table 4.1 reveal the effect of this particular gridwork layout. For example, the loads on shores 3, 8, 9 are about 60 percent of those on shores 2, 6, 7 ( or 4,10,11), respectively, as expected. Differences between shore loads in a common line (shores $2,6,7$ or $3,8,9$ ) are also to be expected because of unequal spacing of shores and differences between interior and end support reactions (shores 2 or 3 vs. shores 6,7 or 8,9 ).

Assuming a unit weight of $150 \mathrm{pcf}\left(2400 \mathrm{~kg} / \mathrm{m}^{3}\right)$ for concrete in accordance with the mix design specifications, the static load in an interior bay will be 39.7 kips $(177 \mathrm{kN})$. This load will be carried by 10 shores on the "average". The 11 instrumented shores should then support a load of about 43.7 kips $(194 \mathrm{kN})$, or about 7 percent less than the sum of the distributed loads (46.78 kips or $208.2 \mathrm{kN}$, table 4.1). This difference is not significant in view of the approximation involved in estimating an "average load" on a group of shores in a bay. For a similar reason, loads based on tributary areas (figure 4.1a and table 4.1) do not provide a good estimate of load distribution to the shores. The approximation in this case is mainly due to the omission of the effect of the aluma beam gridwork in the redistribution of applied loads to the shores.

A key question from the designer's standpoint is whether distributed loads provide a good enough approximation of dead loads. Collectively, the measured loads (col. 2, table 4.1) are 12 percent less than the sum of distributed loads. This difference is on the "safe" side and still not very significant. However, within the group, a considerable amount of disparity exists between individual shore loads. Note, in particular the $8-\mathrm{k}(36-\mathrm{kN})$ difference between the loads on shores 4 and 10 (see col. 2, table 4.1), a condition not likely to be anticipated in design.

There may be a feasible explanation for the difference noted above if, for some reason, shore 4 does not develop fully its share of the superimposed load. In that case, the adjacent shores, one of which is shore 10 (figure 4.1b), will pick up additional loads. By the same token, but to a lesser extent, shore 3 will also pick up some of the load while the load on shore 11 
will be relieved. The trend of the load data seems to corroborate these observations. Note, for instance, that the measured loads on shores 3 and 11 were respectively more and less than the corresponding distributed loads determined by analysis. In the case of the remaining 7 shores, the ratio of distributed-to-measured loads varied between the limits of 0.78 (shore 7) and 1.42 ( shore 1).

The statistical significance of load fluctuations such as the above cannot be fully assessed without additional field data. It is not known, for instance, if, within the limits of practical tolerances, more uniformity between shore loads can be achieved by improved workmanship in the field. In this case, probably more care was exercised in installing the instrumented shores than the other shores in general. The possibility exists that such fluctuations are inherent to the system and tighter control conditions may be impractical and/or ineffective in achieving a more uniform load distribution. If this turns out to be the case, it will become necessary that the design of the shoring system provide for overloads which are not presently considered. The magnitudes of these overloads may be determined by reliability studies once a statistically significant data base through additional field investigations becomes available.

In view of the large scatter between shore loads observed in this study, however, it appears likely that both inproved controls in the field and consideration of overloads in design may be required. Improvements in the field would involve tightening tolerances in the alignment, spacing and level of precompression in the shores as well as tightening maintenance, repair and replacement requirements or procedures for the shoring system components.

Shores are subjected to various amounts of compression when the falsework is installed. It should be noted that non-uniform precompression in the shores will increase the static loads on some of the shores and decrease them on others, but will not alter the total static load on all the shores. In this case, the possibility exists that shore 4 was subjected to less initial precompression than the other shores, or it may not even have been initially in contact with the stringer. However, according to figures 3.8 and 3.11 , both shores 4 and 10 started developing loads at the same time. In fact, until 9:07 a.m., shore 4 developed loads at a faster rate than shore 10. This suggests that shore 4 was structurally engaged initially, and the fact that it failed to continue developing additional loads indicates a loss of axial stiffness, perhaps due to premature yielding of a damaged component, misalignment, etc.

If shore 10 were designed on the basis of distributed static loads alone, its allowable load of $5.19+0.50=5.69 \mathrm{kips}(25.3 \mathrm{kN})$ would have been exceeded by more than 50 percent and the margin and safety would have dropped accordingly, from 2.5 (table 2, apppendix C) to 1.6 . The manufacturer's recommended allowable load on the shore, for a staff extension of $1.7 \mathrm{ft}(0.52 \mathrm{~m})$ in this case, is $8.7 \mathrm{kips}$ or $39 \mathrm{kN}$ (table 2, appendix $\mathrm{C}$ ). This is close to, but less than the total static load of $8.91 \mathrm{kips}(39.6 \mathrm{kN})$ on that shore. The maximum static 
load on the rest of the shores (sums of cols. 3 and 7 , table 4.1) are well below the specified allowable load.

\subsection{LIVE LOADS}

The design of the shores appears to be generally conservative because it uses a 50-psf (2.40-kPa) live load in addition to the dead load (or total static load). Actually, according to the time lapse films, live loads attributed to workers and miscellaneous hand-operated tools (rakes, trowels, etc.) were only a small fraction of the assumed live load at this site. For instance, during the $48 \mathrm{th}$ pour, 10 workers were observed in the bay area over the instrumented shores (table 3.1). This represents an average live load of about 5 psf $(240 \mathrm{~Pa}$ ) in that bay. According to figure 3.29 , the concrete in that bay was already in place. Therefore, it would be reasonable to assume that maximum live loads attributed to workers can occur with full dead load and the two can be superimposed for design purposes.

Whether a 50-psf (2.40-kPa) live load is reasonable to assume in the analysis of construction load effects for design purposes cannot be answered with certainty without additional field data. In this instance, other, and more critical, sources of loading in the "live load" category occurred during and after the placement of concrete. Live loads resulting from the storage of materials and equipment occurred at 1:31 p.m., or about two hours after casting had been completed (see table 3.1). The materials were mostly stacks of forms, some of which were placed in the bay above the instrumented shores. The transient dynamic peak loads occurring during the placement of concrete are examined in the next section.

Figures 3.1-3.5 indicate a noticeable increase in shore loads occurring around 2:50 p.m. and lasting for about 30 minutes. The starting time coincides with the time a stack of forms was placed in bay 4-2* containing the instrumented shores (table 3.1). However, the event of major significance was the placement of an air compressor unit in bay 3-3 at 3:03 p.m. The compressor weighs about $3500 \mathrm{lb}(1585 \mathrm{~kg})$, which is about one-half the weight of a bucketful of concrete, but is concentrated at the two wheels and a bracket post.

According to figures 3.1-3.5, the presence of the compressor did not have a major effect on the instrumented shores which were within the bay sharing a common corner with the bay supporting the compressor. It is estimated that a static load of approximately 1 kip $(4.5 \mathrm{kN})$ can be transmitted to a shore from a wheel directly above. This excludes additional dynamic effects that would occur during its placement, movement or operation.

* Bays are identified by counting from west to east then fron south to north starting with the bay at the southeast corner of the building. 
The compressor was used to blow construction debris from the deck surface. Since its location can vary, it could cause an additional live load of say, 1.5 kips $(6.7 \mathrm{kN})$, inclusive of dynamic effects, on any shore. This is within the "average" 2-kip (8.9-kN) load per shore corresponding to the assumption of 50 psf $(2.40 \mathrm{kPa})$ live load used in the design of the system.

On the basis of the foregoing assessment of shore loads, it would appear that the design live load is generally adequate for superimposed loads after the slab is cast. It should be pointed out, however, that in the case of shore 10 , the allowable load is exceeded even without live load or impact during placement of concrete. Furthermore, the possibility of the compressor being placed on top of that shore, thereby causing a combined load well in excess of its allowable design load cannot be ruled out.

\subsection{DYNAMIC EFFECTS}

Table 4.2 presents a summary of maximum shore loads in which peak dynamic loads resulting from the placement of concrete are included. The two sets of plots in figures 3.7-3.12 and 3.13-3.18 were the source of the tabulated loads. Load increments due to dynamic effects alone may be uncoupled from static and other transient loads as explained below.

The first set of data represents the maximum ordinates of the curves shown in figures 3.7-3.12 during the casting period 9:00-10:30 a.m. and the corresponding pour numbers. The second set of data represents maximum ordinates of the curves shown in figures 3.13-3.18 during the period 6:48-8:30 a.m. the following day. As noted earlier, there is no photographic evidence to identify the types of construction activities in this latter period. Since the casting of the adjacent section of slab had not resumed, however, it is likely that the construction activities involved preparatory tasks prior to the placement of concrete, such as the use of the coinpressor to clear debris from the deck to be cast, delivery and placement of miscellaneous construction materials and equipment on the finished slab, etc. In the process, the possibility of the compressor having been moved to the bay above the instrumented shores cannot be ruled out. This would provide a plausible explanation for the large dynamic disturbances occuring on some of the instrumented shores.

The fifth column in table 4.2 gives the ratios between the maximum tabulated loads (shown underlined) and the corresponding static loads occurring at 11:43 a.m. (table 4.1). Noting that the static loads exclude all transient effects, these ratios represent factors by which the static loads are augmented due to the combined effect of all transient loads. Therefore, the factors representing dynamic effects due to casting operations will be somewhat less (up to five percent less) than the listed ratios for all the shores except shores 5 and 11 in which the maximura loads did not occur during the casting period. In particular, the ratio for shore 6 will be closer to 1.24 without the contribution of the 10 workers observed in bay 4-2 while the 46 th bucket was being discharged (table 3.1). 
After makimg these allowances, it is noted that dynamic effects cause increases of the static (or dead) loads on the individual shores ranging from a low of about three percent to a high of about 90 percent, or 60 precent (shore 11) if shore 4 is exluded. If, instead of ratios, the differences between the underlined loads in table 4.2 and the corresponding static loads in column 2 of table 4.1 are considered (as shown in the last column of table 4.2), the incremental loads due to dynamic effects will range from a low of $0.16 \mathrm{kips}(0.71 \mathrm{kN})$ to a high of 1.39 kips $(6.19 \mathrm{kN})$.

\subsection{DESIGN BASIS}

Current practices in the design of shoring systems may be compared with measured shore loads by reference to provisions in existing codes and standards and the design basis that was actually used for this particular project.

According to ACI Standard 347 [15], vertical loads to be considered in design consist of dead loads, defined as the weight of formwork together with the weight of freshly placed concrete, and live loads, defined as the weight of workmen, equipment, runways and impact, which "shall" be taken as not less than 50 psf $(2.40 \mathrm{kPa})$ of horizontal projection. The definition for dead and live loads in ANSI Al0.9 [16] is similar. However, the minimum allowance for live loads and formwork is specified as 20 psf (960 Pa).

The design loads used for this project are consistent with the ACI provisions cited above; the design of the shoring system was based on a dead load of 105 psf $(5.03 \mathrm{kPa})$, of which 5 psf $(240 \mathrm{~Pa})$ represented the weight of formwork, and a live load of 50 psf $(2.40 \mathrm{kPa})$. The corresponding distributed loads on the shores would then be the distributed static loads due to the 100-psf $(4.80-\mathrm{kPa}$ ) dead load of the concrete (table 4.1 ), multiplied by a factor of 1.55 to account for live loads and formwork. The resulting design loads for the shores will then be the entries in column 2 of table 4.3 .

On the other hand, if this system were designed in accordance with ANSI Al0.9, the design loads would have been those listed in column 3 of table 4.3 , which were obtained from distributed static loads (col.6, table 4.1) multiplied by a factor of 1.2 to account for live load and formwork.

The fourth column of table 4.3 presents the maximum measured loads, shown underlined in table 4.2, augmented by the incremental static loads in the last column of table 4.1 , to account for the weight of falsework and reinforcement not included in the measurements.

On the basis of the data presented in table 4.3 the following observations can be made. With the exception of shores 2 and 4, design loads, calculated in accordance with the ACI 347 code provisions, and taking into consideration the load response of the Aluma beam system, fall within the recommended design load of $8.7 \mathrm{kips}(38.7 \mathrm{kN})$ for the shores. The calculated design loads of shores 2 and 4 exceed the recommended design load by about two percent, which is insignificant. 
The actual design loads compare favorably with measured loads although the latter show significant fluctuations in static (dead) loads from shore to shore as well as loads attributable to dynamic effects (live loads). Thus, in the worst situation (shore 10), the measured load exceeded the recommended design load by about 18 percent, which is a tolerable limit in a design based on a safety margin of about 2.5 for the shores. It is therefore concluded, in so far as this particular study is concerned, that the assumption of a 50-psf $(2.40-\mathrm{kPa})$ live load is likely to compensate for actual differences in shore loads due to all effects. However, the possibility of overloads occurring on shores other than those instrumented should not be ruled out.

The same conclusions cannot be drawn with regard to design loads based on ANSI A10.9, which, in the worst situation (in the case of shore 10), will have underestimated an actual load by about 53 percent. Even if the load on shore 10 is regarded as an unusual occurrence, ANSI-based design loads will still have been exceeded by about 30 percent (in the case of shore 7).

On the basis of the foregoing observations, and in conjunction with this case study, actual dynamic (impact) effects, coupled with dead load fluctuations seemingly inherent to the system, can produce substantially higher loads on certain shores than those based on the 20-psf (958-Pa) minimum allowance for live load plus formwork stipulated by ANSI A10.9. This underscores the need for recognition of a potentially critical overload problem that could result if current ANSI load provisions were followed in the design of shoring systems.

\subsection{LOADS ON RESHORES}

Figures 3.19-3.23 show the development of loads on the nine reshores in the third story during the placement of concrete in section 1 of the fifth story floor slab. The ordinates in these plots represent loads due to the weight of the concrete and any transient loads which may have occurred during the casting operations. Since the load data were gathered after the reshores were in place, they do not include the initial precompression on the individual reshores.

To simplify the interpretation of reshore data it is important to isolate the static component of loads due to the weight of the concrete from transient loads. However, the load history plots for the reshores are conspicuously void of the characteristic dynamic spikes and "wiggles" appearing in the shore load data. The absence of dynamic spikes may be attributable to the fact that the reshores were one story removed from the source of loading and therefore, pulse type effects were attenuated through the falsework system and the slab above before propagating to the reshores.

A note of clarification is needed about the vertical dips appearing randomly in all the plots (figures 3.1-3.28). Most of the dips retained their vertical shape when the data were played out using a time scale expanded by a factor of 320. Therefore, it was concluded that the dips were not related to loads but 
could have been caused by other factors such as electronic dropouts or system noise. Where this was not the case, the plots were retained and reproduced as inserts to the load history plots (figures 3.17 and 3.27).

The effect of transient loads due to the weight of construction personnel and equipment is not sharply defined in the load data plots. The maximum number of workers observed in one bay was 12. This occurred during the 10 th pour in bay 6-2 (figure 3.30 and table 4.2). When concrete was being placed in and around bay 4-2, the number of workers observed in that bay was six or less. This corresponds to an average live load of about 3 psf (144 Pa) in that bay. Therefore, for all practical purposes, the reshore data may be assumed to represent static loads.

Figures 3.19-3.23 show that most of the loads on the reshores developed during the period 9:00-10:30 a.m. Thereafter, the loads kept increasing slowly at different rates. At the time measurements were discontinued, the loads on reshores 2, 4, 5, 7, 8 appeared to have levelled off while those on reshores $1,3,6$, 9 were still rising, although at a slow and diminishing rate.

Table 4.4 compiles the maximum static loads on the reshores occurring at the end of the measurement period. The tabulated loads for reshores 1, 3, 6, 9 may be slightly shy of their respective peaks. The portion of the static loads carried by the fourth story floor slab may be estimated using the data in tables 4.1 and 4.4. Noting that the specified shoring layout in the second through sixth stories is the same, it would be reasonable to assume that the sum of shore loads in column 3 of table 4.1 can be used to approximate the sum of loads on the corresponding shores in the fourth story. Since the load in a bay is shared by ten shores on the "average", the sum of shore loads in table 4.1 (43.6 kips or $194 \mathrm{kN}$ ) is reduced by the factor $10 / 11$ to $39.6 \mathrm{kips}(176 \mathrm{kN})$. Similarly, the sum of reshore loads (table $4.4, \operatorname{col} .2$ ) is reduced to 9.5 kips $(42.3 \mathrm{kN})$ by multiplying it with the ratio $8 / 9$ in which the numerator designates the "average" number of reshores in a bay and the denominator is the total number of instrumented reshores. The difference, 39.6-9.5 = $30.1 \mathrm{kips}(134 \mathrm{kN})$, will then represent approximately the portion of the total superimposed load resisted by the fourth story floor slab.

According to the above estimate, only about 25 percent of the total superimposed load of $40 \mathrm{kips}(178 \mathrm{kN})$ is transmitted to the reshores. In round numbers, the loads carried by the fourth story floor slab and the third story reshores are 30 kips $(134 \mathrm{kN})$ and $10 \mathrm{kips}(44 \mathrm{kN})$, respectively. If three stories were reshored, as specified in the plans, the 10-kip (44-kN) load from the third story reshores would be shared by the third, second and first floor slabs which are interconnected by reshores within the second and first stories.

The portion of the total load transmitted to the third story reshores appears to be low. It would seem that these reshores should have received more than one-half of the superimposed load of the freshly placed concrete. A detailed investigation of load redistribution to the lower floors is beyond the scope 
of this report. However, it is possible to obtain an estimate on the range of distributed loads by examining limiting situations.

A lower bound estimate can be obtained by assuming the axial stiffness of the reshores to be infinite and the stiffness properties of the slabs in the first through fourth floors to be identical. The superimposed loads will then be shared equally by the participating slabs so that each floor will carry a load of 10 kips $(45 \mathrm{kN})$; vs. the $30-\mathrm{kip}(134-\mathrm{kN})$ load on the fourth floor estimated from the field data. Obviously, the upper bound situation in which the reshores are assumed to have no axial stiffness corresponds to the total load of $40 \mathrm{kips}$ (178 kN) being supported completely by the fourth floor. According to a simplified analysis, in which stiffness estimates for the floor slabs and reshores were made based on the data in appendices B and C, respectively, the load carried by the fourth floor would be 13 kips $(58 \mathrm{kN})$, which is slightly over the lower bound estimate.

The large discrepancy between the results of analysis and measurement cannot be explained satisfactorily on the basis of the existing data. The likelihood of a measurement error is ruled out because the gain of the amplifiers were set in the laboratory and was checked before and after the field study, and no error could have been made in the development of the data plots because the zero- and 5-Volt calibrations reproduced on all the plots are correct. On the other hand, according to the time-lapse films, an outrigger was in place on the second floor (figure 2.1) when the fourth floor was being cast. This raises the possibility that reshores removed from bay 4-2 in the second story to permit the evacuation of formwork components via the outrigger, had not been reinstalled at the time the fifth floor was being cast. If this were the case, the calculated loads in the third story reshores would be in agreement with the measured loads.

An important factor in the design of reshores is the amount of precompression they will be subjected to in the field. According to the procedure described in section 2.2, reshores become initially compressed when they are first erected against the forms while the shores are still in place. In the process, part of the loads on the shores is relieved. When the shores and Aluma beams are removed next, the rest of the shore loads is transmitted to the reshores, which will now carry about the same total load that was previously acting on the shores.

The total amount of precompression on the reshores at this stage (before forms are dropped) may be estimated conservatively as the dead load of the fourth floor slab (40 kips or $178 \mathrm{kN}$ per bay), plus an incremental load due to the weight of the falsework and reinforcing bars above $(3.9 \mathrm{kips}$ or $17.4 \mathrm{kN}$; see section 4.1). After adjusting these values by the ratio of the number of instrumented reshores to the "average" number of reshores in a bay, the total 
precompression on the reshores may then be estimated at $(40+3.9)(9 / 8)=$ 49.4 kips $(220 \mathrm{kN})$.

The above estimate puts the "average" precompression in an instrumented reshore at 5.49 kips $(24.4 \mathrm{kN})$. If, instead of an average value, the total precompression is prorated to the individual reshores in accordance with the proportions in which they shared the superimposed static loads (as shown in table 4.4, col. 2), the preloads on the reshores will be those shown in column 3 of table 4.4. The total load in the last column of the table is the sum of the preloads and static loads on the individual reshores.

According to the above estimate, the allowable load of $8.7 \mathrm{kips}$ (39 $\mathrm{kN}$ ) would be exceeded in the case of reshores 2 and 9 by 23 and 55 percent, respectively. On the other hand, if it is assumed that the preload is shared equally by the reshores, the total loads on the individual reshores will be within the specified allowable load.

The two alternative assumptions in the above analysis provide an indication of the possible range of values on reshore loads. However, in the absence of specific data on preloads, coupled with uncertainties about the number of reshored floors, there is no assurance on how closely either set of data in table 4.4 represents actual conditions.

In the final stage of the formwork stripping operations (see section 2.2), the reshores are removed and reinstalled one at a time, permitting recovery of forms. This process can alter significantly the distribution of reshore loads that existed prior to form removal. The assumption that reshores are installed in a manner to free them of compression would be the lower bound situation which will not control their design (conditions at the end of the first stage will) but will create the most critical loading condition in the fourth story floor slab. It is very likely that in practical situations the reshores are reinstalled with a certain minimum degree of snugness to keep them from falling off during the progress of formwork removal and to control the deflection of the slab above.

At the other extreme, the reshores may be reinstalled in a manner to inhibit completely the deflection of the fourth floor. This will restore precompression levels comparable to those at the end of the first stage. It is noted that increasing the snugness of the reshores will increase the redistribution of loads from the upper to lower floors.

\subsection{FUNCTION OF THE TIME LAPSE DATA}

Time lapse photography associates a measured effect with the event that produces it by "visual" means. The time lapse data obtained from this study were used to identify the source, type, location, and generally, the magnitudes of applied loads in relation to measured effects. For example, the location and sequence of the individual pours (figures 3.29 and 3.30 ) and their time of occurrence (tables 3.1 and 3.2 ), together with the specified unit weight and amount of concrete in each pour, were used to determine the dead weight of the concrete and its distribution at any given time. These were then related to the corresponding measured loads on the instrumented shores and reshores (figures 3.7-3.12 and $3.24-3.28$ ). 
As noted earlier, measured loads combine the effect of static and dynamic loads. The time lapse data identified periods during which impact and other peak transient loads occurred (tables 3.1 and 3.2 ), as well as periods when the slab in the vicinity of the instrumented shores was free of personnel and objects. The latter information was used to uncouple the static component of shore loads from transient effects.

The capability to distinguish between static and transient loads identified a basic function of time lapse photography in the study of construction loads. The information contained in the time lapse films suggests other possible uses as well. For example, its potential for predicting impact loads can be examined if additional information becomes available from field investigations making simultaneous use of time lapse equipment and direct data acquisition systems. In that case a statistical correlation may be sought between measured inpact loads and the height, rate and duration of concrete pours (such as documented in tables 3.1 and 3.2). Alternatively, an analysis of the dynamic response of the system can be performed using a forcing function for impact modelled with the aid of the time lapse data. The analytical model can then be refined to produce results consistent with measured impact loads.

If it can be demonstrated that time lapse photography can provide meaningful information on transient as well as static loads, it would offer an attractive alternative for extensive and econonical surveys of construction loads in which direct measurements are made only selectively for the purpose of verification of loads based on time lapse data. 


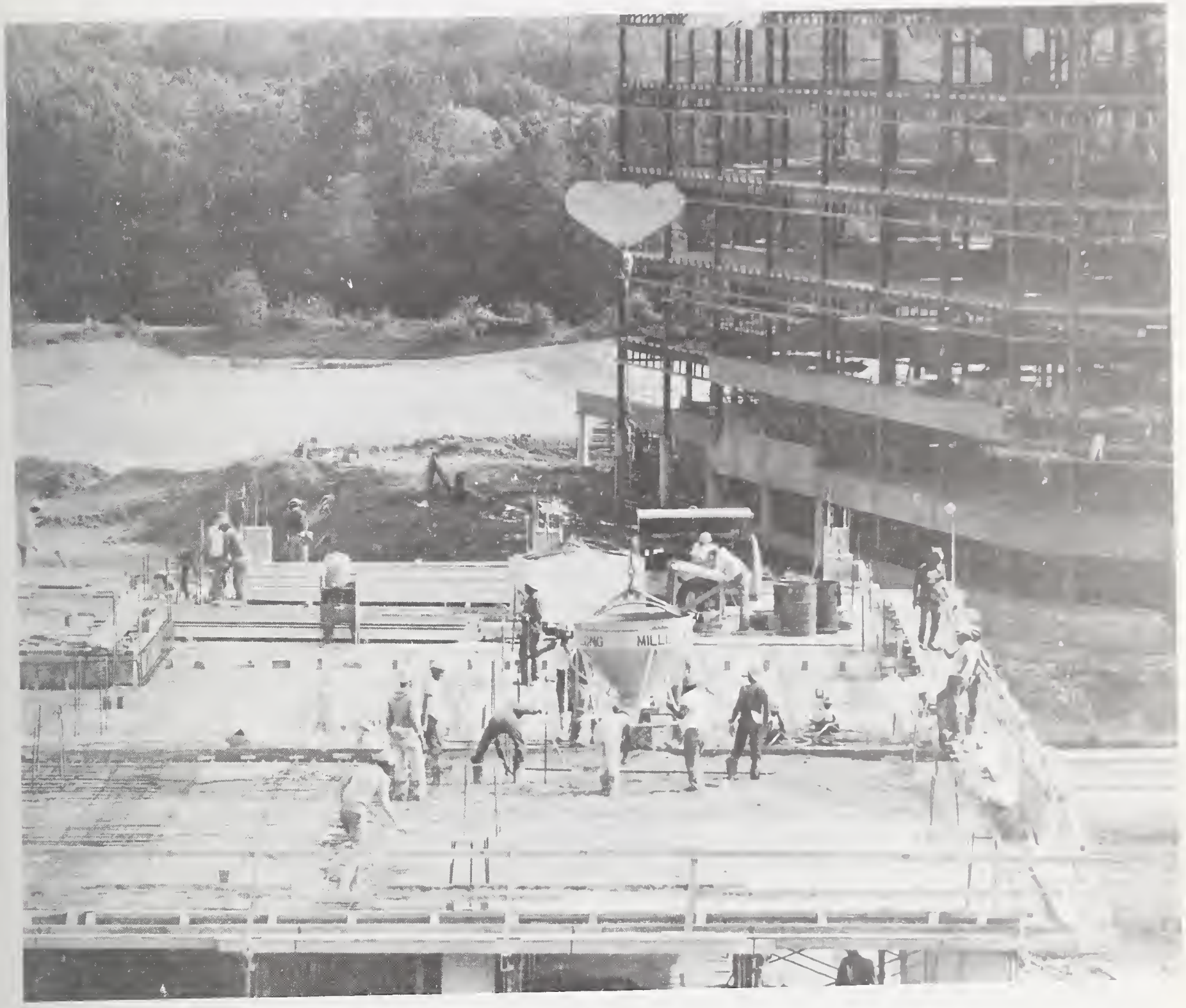

\section{SUMMARY AND CONCLUSIONS}

Construction loads in a multistory concrete flat plate building were measured by means of strain gages mounted on shores and reshores. The construction loads were those occurring during the casting of upper story floor slabs. Simultaneously, a time-lapse camera was used for the purpose of identifying the construction activities associated with the measured loads.

The results of the field study are presented in this report as load versus time plots for the individual instrumented shores and reshores. In addition, 
the time lapse information was used to develop tabular and graphical data on the height, rate and sequence of pours, which were in turn used to separate the component of measured loads due to the weight of the concrete from those due to impact and other transient effects.

The following statements summarize the major findings and conclusions of this study.

1. The distribution of dead loads due to the weight of a freshly cast slab to the shores below is influenced by the structural configuration of the gridwork of joists and stringers supporting the forms. This effect was verified by an analysis in which the structural response of the gridwork was taken into consideration. On the other hand, when the superimposed load was prorated to the shores according to tributary areas, the results of the analysis did not correlate well with measured loads.

2. The maximum measured impact load on a shore occurring during the placement of concrete was 1.29 kips $(5.74 \mathrm{kN})$. This corresponds to an equivalent uniform live load of about $33 \mathrm{psf}(1.6 \mathrm{kPa})$. The live load of construction personnel and various tools and materials was about 5 psf $(240 \mathrm{~Pa})$.

3. The combined dead load of forms, reinforcing bars, and the shoring system was about 10 psf $(480 \mathrm{~Pa})$, or about 10 percent of the dead load of the concrete in the slab.

4. Considering loads from all sources, the assumption of a 50-psf $(2.40-\mathrm{kPa})$ live load is likely to compensate for non-uniformity of residual forces on the shores when they are first installed, and for fluctuations in loads due to various other causes.

5. The results of this study show that construction loads stipulated by the ACI 347 Standard are reasonably close to the peak construction loads measured. However, in several instances, the live loads on the individual shores exceeded those that were obtained on the basis of the live load stipulated by the ANSI Al0.9 Standard.

6. The following differences were observed between shore loads and reshore loads attributed to a freshly cast floor. On the average, the loads on the reshores were 25 percent of those on the shores. This meant that 75 percent of the applied load was resisted by the 7-day old fourth floor. None of the reshores exhibited the charactersitic dynamic spikes in shore loads occuring during the placement of concrete. This suggests that impact type loads are likely to attenuate within the top story. Consequently, impact loads may need to be considered in design only for the part of the shoring system within the top story. 
7. The amount of precompression in the reshores can be a significant factor in their design. No direct measurements of precompression were taken in the field. However, at one stage of the stripping operations, it is possible to install the reshores in such a manner as to relieve the loads that were previously carried by the shores. As a result, when a new floor is cast, the total loading on the reshores may exceed that on the shores. If, in addition, the effect of non-uniform distribution of loads on the reshores is considered, it is possible that the total load on some of the reshores may exceed their allowable design load capacity by considerable margins. 
Facing page: Placement of concrete in the bay above the instmumented shores. 


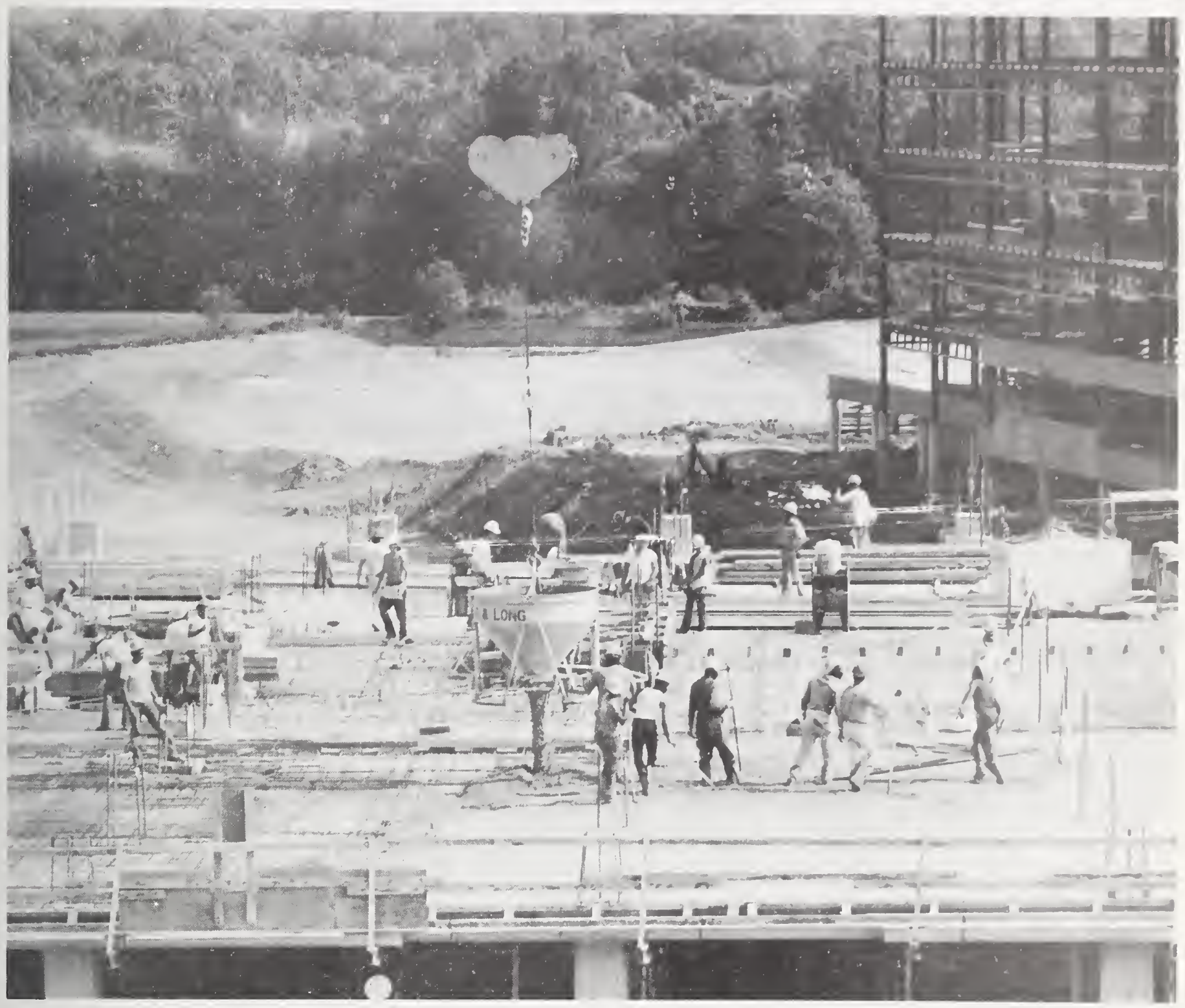

\section{RECOMMENDATIONS}

The experience gained from this field study underscores the importance of additional field data on shore and reshore loads. In particular, it is recommended that field investigations concentrate on measurements of the level of compression in reshores when they are first installed and thereafter, when successive floors are cast. At present there is virtually no field-based information on this subject. 
Additional field studies are needed to develop a good data base for a reliable assessment of load fluctuations on shoring systems and for the formalation of construction load criteria in design.

The construction loads obtained in this study, are, in many instances, far in excess of those specified by the ANSI A10.9 Standard. It is recommended that that the ANSI construction load provisions be reexamined in the light of these findings.

To assemble needed field information on construction loads, it is recommended that improved data acquisition systems be developed with capabilities of assembling and processing a large amount of field data in a time- and costeffective manner. In particular, the utilization of tmie lapse equipment as the principal mechanism for gathering this information should be further explored. 
TABLES AND FIGURES 
Table 2.1: Calibration factors for shore loads

\begin{tabular}{|c|c|c|c|c|c|}
\hline \multicolumn{2}{|c|}{$\begin{array}{l}\text { Channel } \\
\text { Number* }\end{array}$} & $\begin{array}{l}\text { Test } \\
\text { Height } \\
\text { (ft) }\end{array}$ & $\begin{array}{l}\text { Load/mV } \\
\text { Strain Gage } \\
\text { Output** } \\
\text { (kip) }\end{array}$ & $\begin{array}{l}\text { Amplifier } \\
\text { Gain } \\
\text { V/mV Strain } \\
\text { Gage Output }\end{array}$ & $\begin{array}{l}\text { Load/10v of } \\
\text { Amplified } \\
\text { Output** } \\
\text { (kip) }\end{array}$ \\
\hline \multirow{5}{*}{$\begin{array}{l}\text { Single } \\
\text { Post } \\
\text { Shores }\end{array}$} & 1 & 9.417 & 4.016 & 5025 & 7.992 \\
\hline & 2 & 9.417 & 3.788 & 5010 & 7.561 \\
\hline & 3 & 9.417 & 3.846 & 5005 & 7.684 \\
\hline & 4 & 9.417 & 3.984 & 5010 & 7.952 \\
\hline & 5 & 9.417 & 4.167 & 5000 & 8.333 \\
\hline \multirow{2}{*}{$\begin{array}{l}\text { Frame } \\
\text { Shore } \\
\text { No } 1\end{array}$} & 6 & 9.833 & $\begin{array}{c}3.984 \\
(4.016)\end{array}$ & 5000 & $\begin{array}{c}7.968 \\
(8.032)\end{array}$ \\
\hline & 7 & 9.833 & $\begin{array}{c}3.636 \\
(3.623)\end{array}$ & 5020 & $\begin{array}{c}7.243 \\
(7.218)\end{array}$ \\
\hline \multirow{2}{*}{$\begin{array}{l}\text { Frame } \\
\text { Shore } \\
\text { No. } 2\end{array}$} & 8 & 9.833 & $\begin{array}{c}3.788 \\
(3.759)\end{array}$ & 5035 & $\begin{array}{c}7.523 \\
(7.467)\end{array}$ \\
\hline & 9 & 9.833 & $\begin{array}{c}3.788 \\
(3.802)\end{array}$ & 4985 & $\begin{array}{c}7.598 \\
(7.627)\end{array}$ \\
\hline \multirow{2}{*}{$\begin{array}{l}\text { Frame } \\
\text { Shore } \\
\text { No. } 3\end{array}$} & 10 & 9.833 & $\begin{array}{c}3.571 \\
(3.571)\end{array}$ & 5030 & $\begin{array}{c}7.100 \\
(7.100)\end{array}$ \\
\hline & 11 & 9.833 & $\begin{array}{c}3.496 \\
(3.413)\end{array}$ & 5035 & $\begin{array}{c}6.943 \\
(6.778)\end{array}$ \\
\hline
\end{tabular}

$1 \mathrm{kip}=4.45 \mathrm{kN}$

$1 \mathrm{ft}=0.305 \mathrm{~m}$

* Channels 1 through 5 correspond to strain gages mounted on single post shores 1 through 5 respectively. Channels $6-7,8-9$, and 10-11 correspond to strain gages mounted on double-post frame shores 1,2 and 3 , respectively.

The calibration factors in parentheses were obtained by simultaneous loading of the frame shore legs with the loading head positioned concentrically with respect to the frame. 
Table 2.2: Field data Jog for 24-hr period on 5/27-28 starting with placement of concrete in section 1 of fourth story floor slab

\section{EVENT}

TR initial zero check

Start recording

Power loss

Start TL roll 1

Power restored

Casting begun

TC synch. w/ wall clock

Calibr. 1, tape $1(0 \& 5 \mathrm{~V})$

Calibr. 2, tape 1

End TL roll 1

Start TL roll 2

Casting completed

Ambient temp. 72F (22C)

Ambient temp. 74F (23C)

Calibr. 3, tape 1

Ambient temp. 77F (25C)

TL camera off

Calibr. 4, tape 1

Ambient temp. 78F (26C)

Power interruption

Ambient temp. 85F (29C)

Calibr. 5, tape 1

Rewind \& replace tape

Calibr. 6, tape 2

Calibr. 7, tape 2

Ambient temp. 70F (21C)

Ambient temp. 64F (18C)

Calibr. 8, tape 2

Calibr. 9, tape 2

Ambient temp. 68F (20C)

\section{$\underline{\text { DATE }}$}

TIME

$5 / 27 \quad 06: 15$

$07: 21: 00$

$07: 27$

$07: 33$

$07: 52$

$08: 00$

$08: 36: 30$

$08: 50: 00-08: 56: 00$

$11: 00: 40-11: 07: 00$

$11: 34$

$11: 39$

$11: 43$

$12: 00$

$13: 00$

$13: 00: 00-13: 06: 20$

$15: 20$

$15: 25$

$15: 52: 00-15: 58: 05$

$16: 00$

$16: 11: 00-16: 14: 30$

$19: 10$

$19: 43: 00-19: 46: 00$

$19: 47-20: 00$

$20: 01: 30-20: 06: 30$

$5 / 28 \quad 00: 01: 00-00: 09: 15$

$00: 10$

$05: 00$

$05: 08: 00-05: 15: 25$

$08: 28: 00-08: 34: 00$

$08: 30$ 


\section{Table 2.3: Field data log during casting of first section of fifth story floor slab on $6 / 3$}

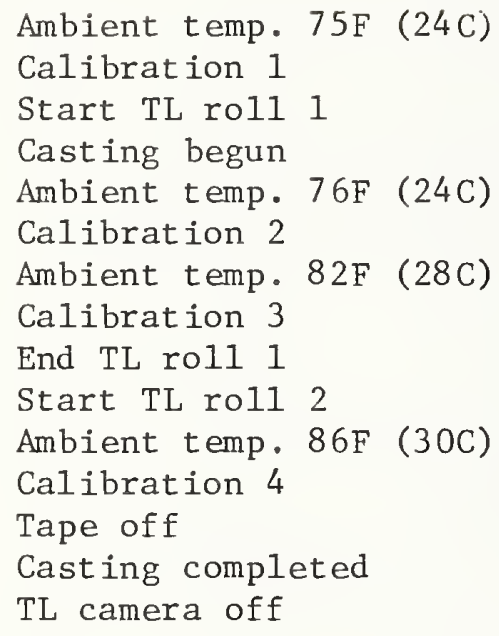


Table 3.1: Data from time lapse films related to measurements of shore loads

\begin{tabular}{|c|c|c|c|c|}
\hline $\begin{array}{l}\text { Frame } \\
\text { Number }\end{array}$ & $\begin{array}{l}\text { Real Time } \\
\text { (hr:min) }\end{array}$ & $\begin{array}{l}\text { Duration of } \\
\text { Pour (sec) }\end{array}$ & $\begin{array}{l}\text { Height of } \\
\text { Pour (in) }\end{array}$ & Event \\
\hline 1 & $7: 33$ & - & & Start roll 1 \\
\hline $370-3$ & $7: 58$ & 16 & $47,49,49,64$ & Pour 1 \\
\hline $404-7$ & $8: 01$ & 16 & $24,24,49,64$ & 2 \\
\hline $437-9$ & $8: 03$ & 12 & $38 \times 3$ & 3 \\
\hline $474-6$ & $8: 05$ & 12 & $47 \times 3$ & 4 \\
\hline $510-1$ & $8: 06$ & 8 & 24,38 & 5 \\
\hline $543-4$ & $8: 10$ & 8 & $64 \times 2$ & 6 \\
\hline $588-9$ & $8: 13$ & 8 & $47 \times 2$ & 7 \\
\hline $623-4$ & $8: 15$ & 8 & 64,24 & 8 \\
\hline $654-5$ & $8: 17$ & 8 & $56 \times 2$ & 9 \\
\hline $687-8$ & $8: 19$ & 8 & $56 \times 2$ & 10 \\
\hline $720-1$ & $8: 22$ & 8 & $47 \times 2$ & 11 \\
\hline $752-3$ & $8: 24$ & 8 & $47 \times 2$ & 12 \\
\hline $802-5$ & $8: 27$ & 16 & $24 \times 4$ & 13 \\
\hline $841-6$ & $8: 30$ & 24 & $38 \times 6$ & 14 \\
\hline $879-80$ & $8: 32$ & 8 & $24 \times 2$ & 15 \\
\hline $914-5$ & $8: 34$ & 8 & $44 \times 2$ & 16 \\
\hline $955-6$ & $8: 37$ & 8 & 64,47 & 17 \\
\hline $994-5$ & $8: 40$ & 8 & $56 \times 2$ & 18 \\
\hline $1026-8$ & $8: 42$ & 12 & $64,56,47$ & 19 \\
\hline $1062-7$ & $8: 44$ & 24 & $47 \times 6$ & 20 \\
\hline $1100-1$ & $8: 47$ & 8 & 24,56 & 21 \\
\hline $1141-3$ & $8: 50$ & 12 & $38 \times 3$ & 22 \\
\hline $1175-6$ & $8: 52$ & 8 & $47 \times 2$ & 23 \\
\hline $1208-9$ & $8: 54$ & 8 & $56 \times 2$ & 24 \\
\hline $1244-6$ & $8: 57$ & 12 & $64,24,38$ & 25 \\
\hline 1283 & $8: 59$ & 4 & 44 & 26 \\
\hline 1283 & $8: 59$ & - & & 8 men in bay $5-1$ \\
\hline $1326-8$ & $9: 02$ & 12 & $56 \times 3$ & Pour 27 \\
\hline $1326-8$ & $9: 02$ & - & & $\begin{array}{l}10 \text { men in bay } 5-2 \text {, } \\
6 \text { men in bay } 5-1\end{array}$ \\
\hline $1366 \&$ & & & & \\
\hline 1371 & $9: 05$ & 8 & 47,38 & Pour 28 \\
\hline 1408 & $9: 07$ & 4 & 67 & 29 \\
\hline 1442 & $9: 10$ & 4 & 78 & 30 \\
\hline 1489 & $9: 13$ & 4 & 47 & 31 \\
\hline 1489 & $9: 13$ & - & - & 9 men in bay $5-2$ \\
\hline $1538-40$ & $9: 16$ & 12 & $47 \times 3$ & Pour 32 \\
\hline $1592-3$ & $9: 20$ & 8 & $38 \times 2$ & 33 \\
\hline $1632-4$ & $9: 23$ & 12 & $24 \times 3$ & 34 \\
\hline 1671 & $9: 25$ & 4 & 64 & 35 \\
\hline $1731-2$ & $9: 29$ & 8 & $47 \times 2$ & 36 \\
\hline $1886-8$ & $9: 39$ & 12 & $44 \times 3$ & 37 \\
\hline $1886-8$ & $9: 39$ & - & - & 8 men in bay $4-2$ \\
\hline
\end{tabular}


Table 3.1 (con't.)

\begin{tabular}{|c|c|c|c|c|}
\hline $\begin{array}{l}\text { Frame } \\
\text { No. }\end{array}$ & $\begin{array}{l}\text { Real Tine } \\
\text { (hr:min) }\end{array}$ & $\begin{array}{l}\text { Duration of } \\
\text { Pour (sec) }\end{array}$ & $\begin{array}{l}\text { Height of } \\
\text { Pour (in) }\end{array}$ & Event \\
\hline $\begin{array}{l}1921-3 \\
1981-2 \\
2016-7\end{array}$ & $\begin{array}{l}9: 42 \\
9: 46 \\
9: 48\end{array}$ & $\begin{array}{r}12 \\
8 \\
8\end{array}$ & $\begin{array}{l}47 \times 3 \\
56,47 \\
38 \times 2\end{array}$ & $\begin{array}{r}\text { Pour } 38 \\
39 \\
40 \\
\end{array}$ \\
\hline $2049-50$ & $9: 50$ & 8 & 24,44 & 41 \\
\hline $2085-7$ & $9: 53$ & 12 & $24 \times 2,38$ & 42 \\
\hline $2122-3$ & $9: 55$ & 8 & 64,47 & 43 \\
\hline $2165-6$ & $9: 58$ & 8 & 76,47 & 44 \\
\hline $2195-6$ & $10: 00$ & 8 & 38,47 & 45 \\
\hline $2225-6$ & $10: 02$ & 8 & $44 \times 2$ & 46 \\
\hline $2225-6$ & $10: 02$ & - & & 10 men in bay $4-2$ \\
\hline 2255 & $10: 04$ & 4 & 38 & Pour 47 \\
\hline $2297-8$ & $10: 07$ & 8 & 86,47 & 48 \\
\hline $2297-8$ & $10: 07$ & - & - & 10 men in bay $4-2$ \\
\hline $2310-$ & $10: 08-$ & & & \\
\hline 2550 & $10: 24$ & - & - & Hoisting misc. mat'1s \\
\hline $2561-2$ & $10: 24$ & 8 & $47 \times 2$ & Pour 49 \\
\hline $2595-7$ & $10: 27$ & 12 & $38 \times 3$ & 50 \\
\hline $2626-9$ & $10: 29$ & 16 & $24 \times 4$ & 51 \\
\hline $2657-9$ & $10: 31$ & 12 & $47,64 \times 2$ & 52 \\
\hline $2696-8$ & $10: 33$ & 12 & $47 \times 3$ & Pour 53 \\
\hline $2725-6$ & $10: 35$ & 8 & 47,56 & 54 \\
\hline $2756-7$ & $10: 37$ & 8 & $47 \times 2$ & 55 \\
\hline $2787-8$ & $10: 39$ & 8 & 38,56 & 56 \\
\hline $2815-7$ & $10: 41$ & 12 & $38 \times 3$ & 57 \\
\hline $2863-4$ & $10: 44$ & 8 & 76,47 & 58 \\
\hline $2895-7$ & $10: 47$ & 12 & $47 \times 3$ & 59 \\
\hline $2930-1$ & $10: 49$ & 8 & $47 \times 3$ & 60 \\
\hline $2959-61$ & $10: 51$ & 12 & $56,64 \times 2$ & 61 \\
\hline $2987-8$ & $10: 53$ & 8 & $38 \times 2$ & 62 \\
\hline $3049--50$ & $10: 57$ & 8 & 56,76 & 63 \\
\hline $3081-3$ & $10: 59$ & 12 & $56 \times 3$ & 64 \\
\hline $3113-7$ & $11: 01$ & 20 & $47 \times 2,38 \times 3$ & 65 \\
\hline $3147-51$ & $11: 04$ & 20 & $47 \times 3,64 \times 2$ & 66 \\
\hline $3185-8$ & $11: 06$ & 16 & $47 \times 2,56 \times 2$ & 67 \\
\hline $3218-20$ & $11: 08$ & 12 & $56 \times 3$ & 68 \\
\hline $3249-51$ & $11: 10$ & 12 & $31,47 \times 2$ & 69 \\
\hline $3281-2$ & $11: 12$ & 8 & $56 \times 2$ & 70 \\
\hline $3312-5$ & $11: 14$ & 16 & $56 \times 2,76 \times 2$ & 71 \\
\hline $3359-62$ & $11: 18$ & 16 & $64 \times 2,76 \times 2$ & 72 \\
\hline $3388-94$ & $11: 20$ & 28 & $64 \times 7$ & 73 \\
\hline $3420-2$ & $11: 22$ & 12 & $47 \times 2,64$ & 74 \\
\hline $3450-1$ & $11: 24$ & 8 & 47,56 & 75 \\
\hline $3476-7$ & $11: 25$ & 8 & $47 \times 2$ & 76 \\
\hline $3558-9$ & $11: 31$ & 8 & $76 \times 2$ & 77 \\
\hline $3588-91$ & $11: 33$ & 16 & $47 \times 2$ & 78 \\
\hline 3603 & $11: 34$ & - & - & End roll 1 \\
\hline \multirow{2}{*}{\multicolumn{2}{|c|}{$\begin{array}{lll}\text { Roll Change - } & \text { Change - }\end{array}$}} & $?$ & $?$ & Pour 79 \\
\hline & & $?$ & $?$ & Pour 80 \\
\hline
\end{tabular}


Table 3.1 (con't.)

\begin{tabular}{|c|c|c|c|c|}
\hline $\begin{array}{l}\text { Frame } \\
\text { No. }\end{array}$ & $\begin{array}{l}\text { Real Time } \\
\text { (hr:min) }\end{array}$ & $\begin{array}{l}\text { Duration of } \\
\text { Pour (sec) }\end{array}$ & $\begin{array}{l}\text { Height of } \\
\text { Pour (in) }\end{array}$ & Event \\
\hline $\begin{array}{l}1 \\
11-19 \\
56-9\end{array}$ & $\begin{array}{l}11: 39 \\
11: 40 \\
11: 43\end{array}$ & $\begin{array}{l}- \\
36 \\
16\end{array}$ & $\begin{array}{l}47 \times 9 \\
47 \times 2,56 \times 2\end{array}$ & $\begin{array}{l}\text { Start of roll } 2 \\
\text { Pour } 81 \\
\text { Pour } 82\end{array}$ \\
\hline $\begin{array}{l}\text { Frame } \\
\text { No. }\end{array}$ & $\begin{array}{l}\text { Rea1 } \\
\text { Time }\end{array}$ & \multicolumn{3}{|c|}{ Event } \\
\hline $\begin{array}{l}1680 \\
1750 \\
2020 \\
2034 \\
2100\end{array}$ & $\begin{array}{l}13: 31 \\
13: 36 \\
13: 54 \\
13: 55 \\
13: 59\end{array}$ & \multicolumn{3}{|c|}{$\begin{array}{l}\text { 3-ft high stacked forms placed on bay } 6-1 \\
1 \text { 1/2-ft high stacked forms placed on bay } 6-1 \\
11 / 2 \text { ft high stacked forms moved to bay } 5-2 \\
\text { 4-ft high stacked forms placed in bay } 6-2 \\
\text { 3-ft high stacked forms placed in bay } 6-2\end{array}$} \\
\hline $\begin{array}{l}2140 \\
2200 \\
2640 \\
2690 \\
2750\end{array}$ & $\begin{array}{l}14: 02 \\
14: 06 \\
14: 35 \\
14: 38 \\
14: 42\end{array}$ & \multicolumn{3}{|c|}{$\begin{array}{l}\text { Ditto } \\
\text { Ditto } \\
4-f t \text { high stacked forms placed in bay } 3-2 \\
\text { Ditto } \\
\text { Ditto }\end{array}$} \\
\hline $\begin{array}{l}2850 \\
2890 \\
3060 \\
3240 \\
3270 \\
3395\end{array}$ & $\begin{array}{l}14: 49 \\
14: 52 \\
15: 03 \\
15: 15 \\
15: 17 \\
15: 25\end{array}$ & \multicolumn{3}{|c|}{$\begin{array}{l}\text { 4-ft high stacked forms placed in bay } 4-2 \\
3-\mathrm{ft} \text { high stacked forms placed in bay } 6-3 \\
3500-1 \mathrm{~b} \text { compressor placed in bay } 3-3 \\
\text { Stack in bay } 4-2 \text { split into } 3 \text { stacks, same bay } \\
\text { Middle stack of precedent removed } \\
\text { End of roll } 2\end{array}$} \\
\hline
\end{tabular}

1 in $=25.4 \mathrm{~mm}$ 
Table 3.2: Data from time lapse films related to measurements of reshore loads

\begin{tabular}{|c|c|c|c|c|}
\hline $\begin{array}{l}\text { Frame } \\
\text { No. }\end{array}$ & $\begin{array}{l}\text { Real Time } \\
\text { (hr:min) }\end{array}$ & $\begin{array}{l}\text { Duration of } \\
\text { Pour (sec) }\end{array}$ & $\begin{array}{l}\text { Height of } \\
\text { Pour (in) }\end{array}$ & Event \\
\hline $\begin{array}{l}1 \\
36-7 \\
74-6 \\
110-1 \\
147-9 \\
185-7\end{array}$ & $\begin{array}{l}7: 42 \\
7: 45 \\
7: 47 \\
7: 49 \\
7: 52 \\
7: 54\end{array}$ & $\begin{array}{r}- \\
8 \\
12 \\
8 \\
12 \\
12\end{array}$ & $\begin{array}{l}- \\
38,47 \\
47,56,67 \\
47 \times 2 \\
47 \times 2,53 \\
47 \times 3\end{array}$ & $\begin{array}{l}\text { Start roll } 1 \\
\text { Pour } 1 \\
2 \\
3 \\
4 \\
5 \\
\end{array}$ \\
\hline $\begin{array}{l}223-4 \\
258-9 \\
294 \\
325-6 \\
360-2 \\
\end{array}$ & $\begin{array}{l}7: 57 \\
7: 59 \\
8: 02 \\
8: 04 \\
8: 06\end{array}$ & $\begin{array}{r}8 \\
8 \\
4 \\
8 \\
12 \\
\end{array}$ & $\begin{array}{l}38,64 \\
38,47 \\
56 \\
47,64 \\
47,64 \times 2 \\
\end{array}$ & $\begin{array}{c}6 \\
7 \\
8 \\
9 \\
10 \\
\end{array}$ \\
\hline $\begin{array}{l}360-2 \\
397 \\
437-8 \\
470-1 \\
504-5 \\
558-9\end{array}$ & $\begin{array}{l}8: 06 \\
8: 08 \\
8: 11 \\
8: 13 \\
8: 16 \\
8: 19\end{array}$ & $\begin{array}{l}-\overline{4} \\
8 \\
8 \\
8 \\
8\end{array}$ & $\begin{array}{l}76 \\
56 \times 2 \\
64 \times 2 \\
47,38 \\
56,76 \\
\end{array}$ & $\begin{array}{l}12 \text { men in bay } 6-1 \\
\text { Pour } 11 \\
12 \\
13 \\
14 \\
15\end{array}$ \\
\hline $\begin{array}{l}616-8 \\
652-3 \\
686-7 \\
732-4 \\
765-7 \\
\end{array}$ & $\begin{array}{l}8: 23 \\
8: 25 \\
8: 28 \\
8: 31 \\
8: 33\end{array}$ & $\begin{array}{r}12 \\
8 \\
8 \\
12 \\
12 \\
\end{array}$ & $\begin{array}{l}47,56,76 \\
56,47 \\
31 \times 2 \\
76 \times 3 \\
67 \times 2,47\end{array}$ & $\begin{array}{l}16 \\
17 \\
18 \\
19 \\
20 \\
\end{array}$ \\
\hline $\begin{array}{l}797-800 \\
833-5 \\
868-70 \\
913-5 \\
952-3 \\
\end{array}$ & $\begin{array}{l}8: 35 \\
8: 38 \\
8: 40 \\
8: 43 \\
8: 45\end{array}$ & $\begin{array}{r}16 \\
12 \\
12 \\
12 \\
8 \\
\end{array}$ & $\begin{array}{l}56,44 \times 2,47 \\
44 \times 3 \\
76 \times 3 \\
47 \times 2,64 \\
47,67\end{array}$ & $\begin{array}{l}21 \\
22 \\
23 \\
24 \\
25\end{array}$ \\
\hline $\begin{array}{l}987-9 \\
1100 \\
1135-7 \\
1173-4 \\
1209 \\
\end{array}$ & $\begin{array}{l}8: 48 \\
8: 55 \\
8: 58 \\
9: 00 \\
9: 03\end{array}$ & $\begin{array}{r}12 \\
4 \\
12 \\
8 \\
4 \\
\end{array}$ & $\begin{array}{l}47 \times 3 \\
47 \\
44,61,76 \\
38,76 \\
56 \\
\end{array}$ & $\begin{array}{r}26 \\
27 \\
28 \\
29 \\
30 \\
\end{array}$ \\
\hline $\begin{array}{l}1259 \\
1259 \\
1294-5 \\
1330-1 \\
1364-5 \\
1401-2\end{array}$ & $\begin{array}{l}9: 06 \\
9: 06 \\
9: 08 \\
9: 11 \\
9: 13 \\
9: 15.5\end{array}$ & $\begin{array}{l}4 \\
- \\
8 \\
8 \\
8 \\
8\end{array}$ & $\begin{array}{l}56 \\
- \\
56,64 \\
38,56 \\
56,47 \\
47,64 \\
\end{array}$ & $\begin{array}{l}31 \\
9 \text { men in bay } 4-2 \\
\text { Pour } 32 \\
33 \\
34 \\
35 \\
\end{array}$ \\
\hline $\begin{array}{l}1436-7 \\
1469-71 \\
1503-4 \\
1532-8 \\
1577-9 \\
\end{array}$ & $\begin{array}{l}9: 18 \\
9: 20 \\
9: 22 \\
9: 24 \\
9: 27 \\
\end{array}$ & $\begin{array}{r}8 \\
12 \\
8 \\
28 \\
12 \\
\end{array}$ & $\begin{array}{l}64 \times 2 \\
56,47,56 \\
56,76 \\
? \\
56,47,56 \\
\end{array}$ & $\begin{array}{l}36 \\
37 \\
38 \\
39 \\
40\end{array}$ \\
\hline $\begin{array}{l}1619-20 \\
1652\end{array}$ & $\begin{array}{l}9: 30 \\
9: 32\end{array}$ & $\begin{array}{l}8 \\
4\end{array}$ & $\begin{array}{l}47,67 \\
47\end{array}$ & $\begin{array}{l}41 \\
42\end{array}$ \\
\hline
\end{tabular}


Table 3.2 (con't.)

\begin{tabular}{|c|c|c|c|c|}
\hline $\begin{array}{l}\text { Frame } \\
\text { No. }\end{array}$ & $\begin{array}{l}\text { Real Tine } \\
\text { (hr:min) }\end{array}$ & $\begin{array}{l}\text { Duration of } \\
\text { Pour (sec) }\end{array}$ & $\begin{array}{l}\text { Height of } \\
\text { Pour (in) }\end{array}$ & Event \\
\hline $1686-7$ & $9: 34.5$ & 8 & 38,47 & Pour 43 \\
\hline $1720-1$ & $9: 37$ & 8 & 47,64 & 44 \\
\hline 1754 & $9: 39$ & 4 & 67 & 45 \\
\hline $1800-$ & & & & \\
\hline 2000 & $9: 39$ & - & - & Hoist misc. mat'1s \\
\hline $2069-70$ & $10: 00$ & 8 & 47,56 & Pour 46 \\
\hline $2106-7$ & $10: 02.5$ & 8 & 47,56 & 47 \\
\hline $2137-9$ & $10: 04.5$ & 12 & $47 \times 2,76$ & 48 \\
\hline 2176 & $10: 07$ & 4 & & 49 \\
\hline $2274-5$ & $10: 14$ & 8 & 56,64 & 50 \\
\hline $2323-4$ & $10: 17$ & 8 & 31,47 & 51 \\
\hline $2357-9$ & $10: 19$ & 12 & $56 \times 3$ & 52 \\
\hline $2389-90$ & $10: 21$ & 8 & $76 \times 2$ & 53 \\
\hline $2457-8$ & $10: 26$ & 8 & 47,56 & 54 \\
\hline 2498 & $10: 28.5$ & 4 & 56 & 55 \\
\hline 2527 & $10: 30.5$ & 4 & 67 & 56 \\
\hline 2566 & $10: 33$ & 4 & 67 & 57 \\
\hline 2633 & $10: 37.5$ & 4 & 56 & 58 \\
\hline $2765-6$ & $10: 46$ & 8 & 47,56 & 59 \\
\hline $2800-1$ & $10: 49$ & 8 & $76 \times 2$ & 60 \\
\hline 2836 & $10: 51$ & 4 & 76 & 61 \\
\hline $2867-8$ & $10: 53$ & 8 & $56 \times 2$ & 62 \\
\hline $2900-$ & $10: 55-$ & & & Stairs, misc. mat'ls \\
\hline 3050 & $11: 05$ & - & - & hoisted \\
\hline $3116-7$ & $11: 10$ & 8 & 56,64 & Pour 63 \\
\hline $3149-50$ & $11: 12$ & 8 & $64 \times 2$ & 64 \\
\hline 3181 & $11: 14$ & 4 & 76 & 65 \\
\hline $3222-4$ & $11: 17$ & 12 & $24,47,38$ & 66 \\
\hline $3251-4$ & $11: 19$ & 16 & $47 \times 2,56 \times 2$ & 67 \\
\hline $3292-3$ & $11: 21.5$ & 8 & $76 \times 2$ & 68 \\
\hline $3322-3$ & $11: 23.5$ & 8 & $56 \times 2$ & 69 \\
\hline $3347-9$ & $11: 25$ & 12 & $76 \times 3$ & 70 \\
\hline $3393-4$ & $11: 28$ & 8 & 56,64 & 71 \\
\hline 3421 & $11: 30$ & 4 & 64 & 72 \\
\hline $3447-8$ & $11: 32$ & 8 & 38,56 & 73 \\
\hline $3476-8$ & $11: 34$ & 12 & $47 \times 2,76$ & 74 \\
\hline $3510-13$ & $11: 36$ & 16 & $38 \times 4$ & 75 \\
\hline $3542-3$ & $11: 38$ & 8 & 21,47 & 76 \\
\hline $3574-5$ & $11: 40$ & 8 & $76 \times 2$ & 77 \\
\hline 3592 & $11: 41$ & - & - & End roll 1 \\
\hline 1 & $11: 42$ & - & - & Start roll 2 \\
\hline $96-9$ & $11: 48.5$ & 16 & $56 \times 2,76 \times 2$ & Pour 78 \\
\hline $\begin{array}{l}156- \\
462\end{array}$ & $11: 53$ & 15 & $38-56$ & Pour $79,16 \mathrm{fr} / \mathrm{s}$ \\
\hline $574-9$ & $11: 61$ & 24 & $56 \times 6$ & Pour 80 \\
\hline $1798-$ & & & & \\
\hline 1803 & $13: 23$ & 24 & $56 \times 6$ & 81 \\
\hline $1860-3$ & $13: 27$ & 16 & $47 \times 4$ & 82 \\
\hline 1913-9 & $13: 31$ & 28 & $64 \times 3,76 \times 4$ & 83 \\
\hline $2434-40$ & $13: 53$ & 28 & $?$ & 84 \\
\hline
\end{tabular}

1 in $=25.4 \mathrm{~mm}$ 


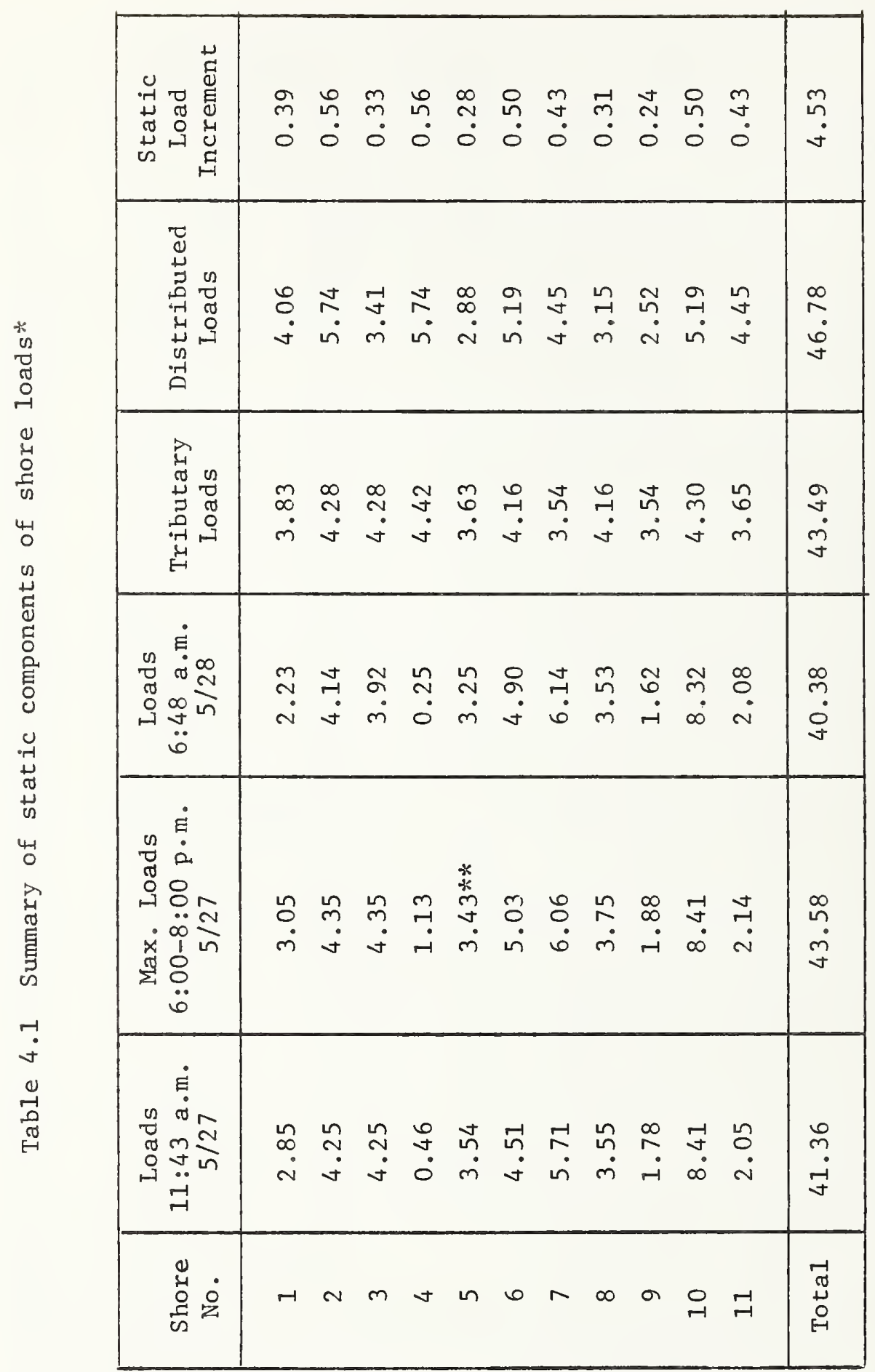

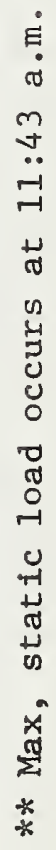




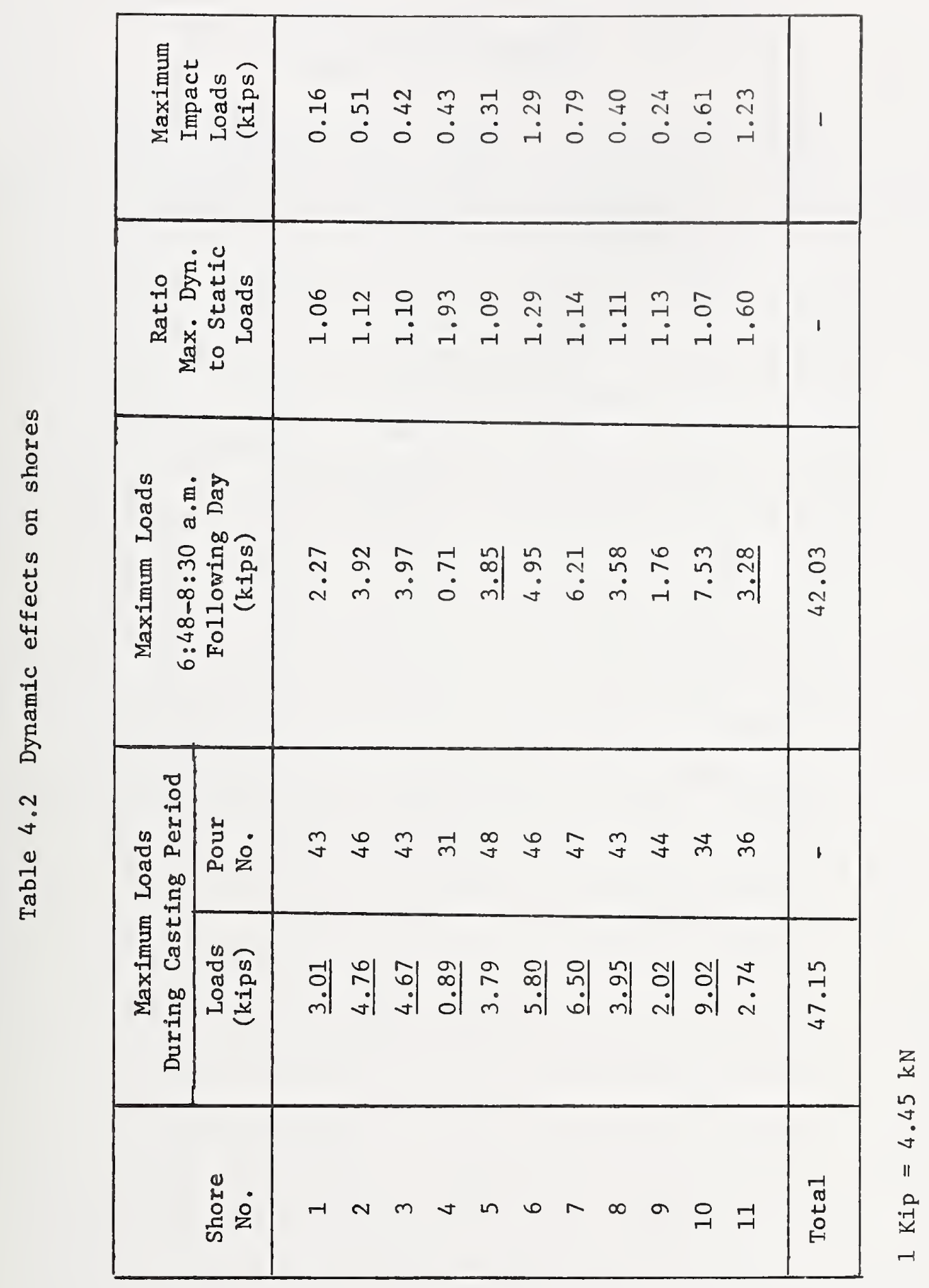


Table 4.3: Comparison between design and measured shore loads

\begin{tabular}{|c|c|c|c|}
\hline $\begin{array}{c}\text { Shore } \\
\text { No. }\end{array}$ & $\begin{array}{c}\text { Actua1 } \\
\text { Design } \\
\text { Loads } \\
\text { (kips) }\end{array}$ & $\begin{array}{c}\text { ANSI A 10.9 } \\
\text { Design Loads } \\
\text { (kips) }\end{array}$ & $\begin{array}{c}\text { Measured } \\
\text { Loads } \\
\text { (kips) }\end{array}$ \\
\hline 1 & 6.29 & 4.87 & 3.40 \\
2 & 8.90 & 6.89 & 5.32 \\
3 & 5.29 & 4.09 & 5.00 \\
4 & 8.90 & 6.89 & 1.45 \\
5 & 4.46 & 3.46 & 4.13 \\
6 & 8.04 & 6.23 & 6.30 \\
7 & 6.90 & 5.34 & 6.93 \\
8 & 4.88 & 3.78 & 4.26 \\
9 & 3.91 & 3.02 & 2.26 \\
10 & 8.04 & 6.23 & 9.52 \\
11 & 6.90 & 5.34 & 3.71 \\
\hline Tota1 & 72.51 & 56.14 & 52.28 \\
\hline
\end{tabular}

$1 \mathrm{Kip}=4.45 \mathrm{kN}$ 
Table 4.4: Summary of static loads on reshores

\begin{tabular}{|c|c|c|c|}
\hline $\begin{array}{c}\text { Reshore } \\
\text { No. }\end{array}$ & $\begin{array}{c}\text { Maximum } \\
\text { Static Load } \\
\text { (kips) }\end{array}$ & $\begin{array}{c}\text { Precompression } \\
\text { (kips) }\end{array}$ & $\begin{array}{c}\text { Total Load } \\
\text { (kips) }\end{array}$ \\
\hline 1 & 1.00 & 4.65 & 5.65 \\
2 & 1.89 & 8.78 & 10.67 \\
3 & 0.96 & 4.46 & 5.42 \\
4 & 1.15 & 5.34 & 6.49 \\
5 & 0.75 & 3.49 & 4.24 \\
6 & 1.18 & 5.48 & 6.66 \\
7 & 0.68 & 3.16 & 3.84 \\
8 & 0.64 & 2.97 & 3.61 \\
9 & 2.38 & 11.07 & 13.45 \\
\hline Total & 10.63 & 49.40 & 60.03 \\
\hline
\end{tabular}

$1 \mathrm{Kip}=4.45 \mathrm{kN}$ 

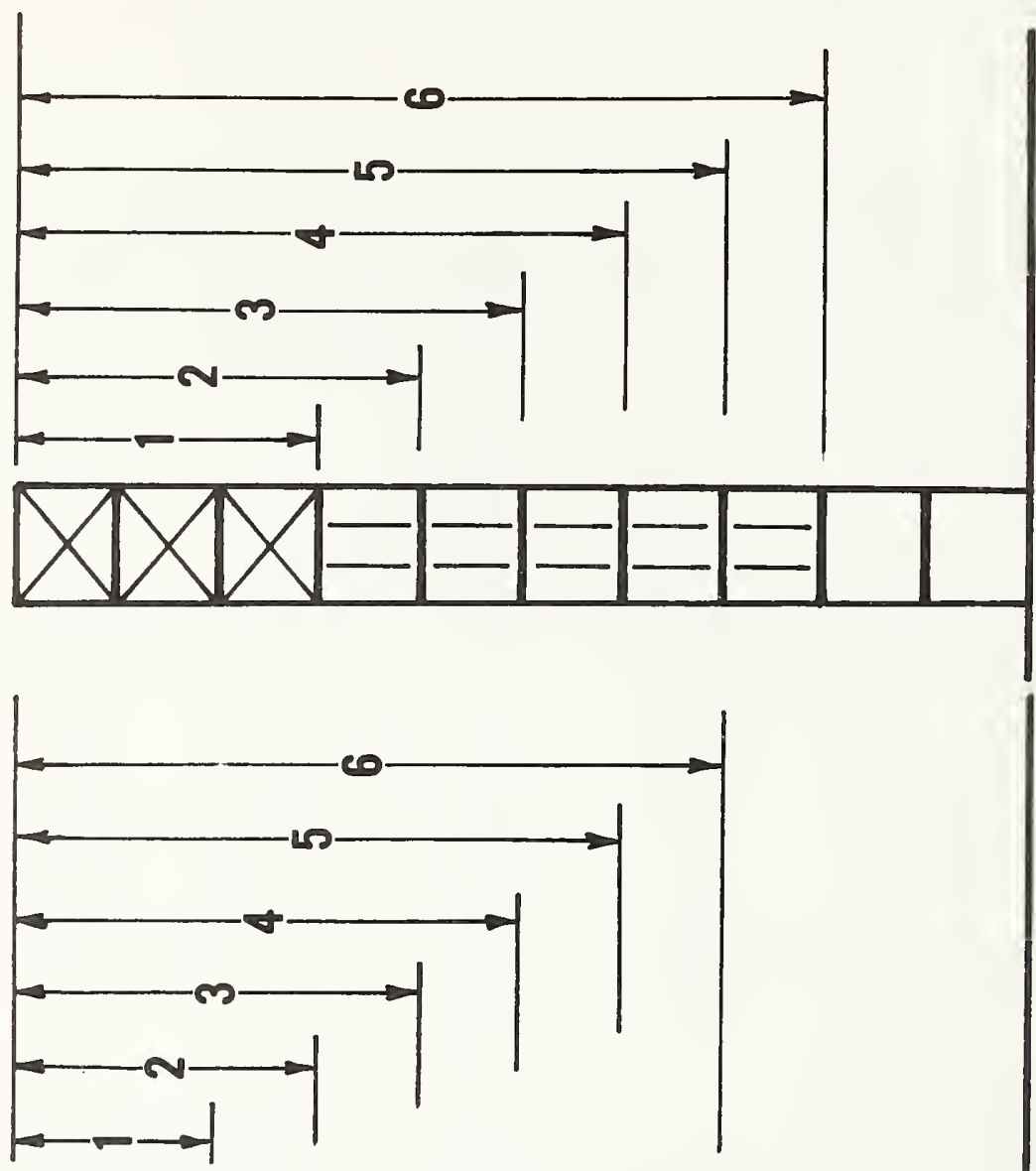

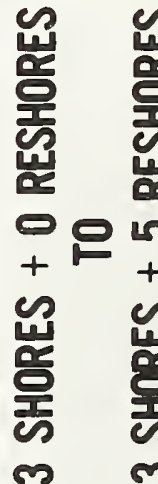

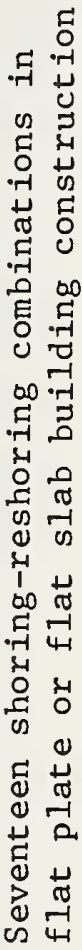

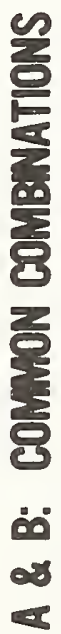

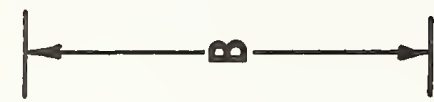

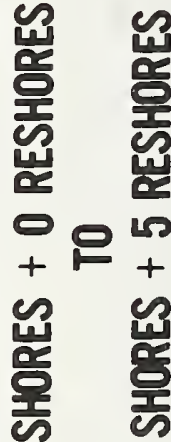
볼

+
w
운
m

N N

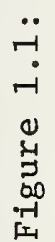
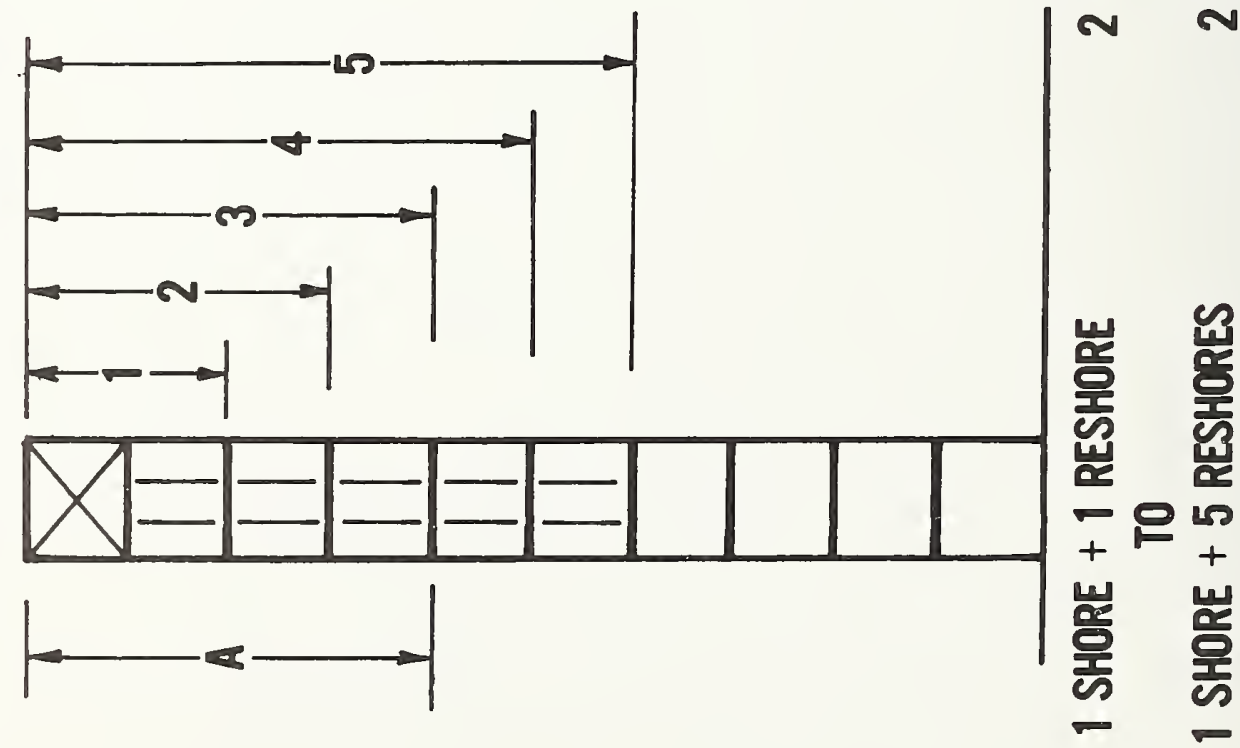


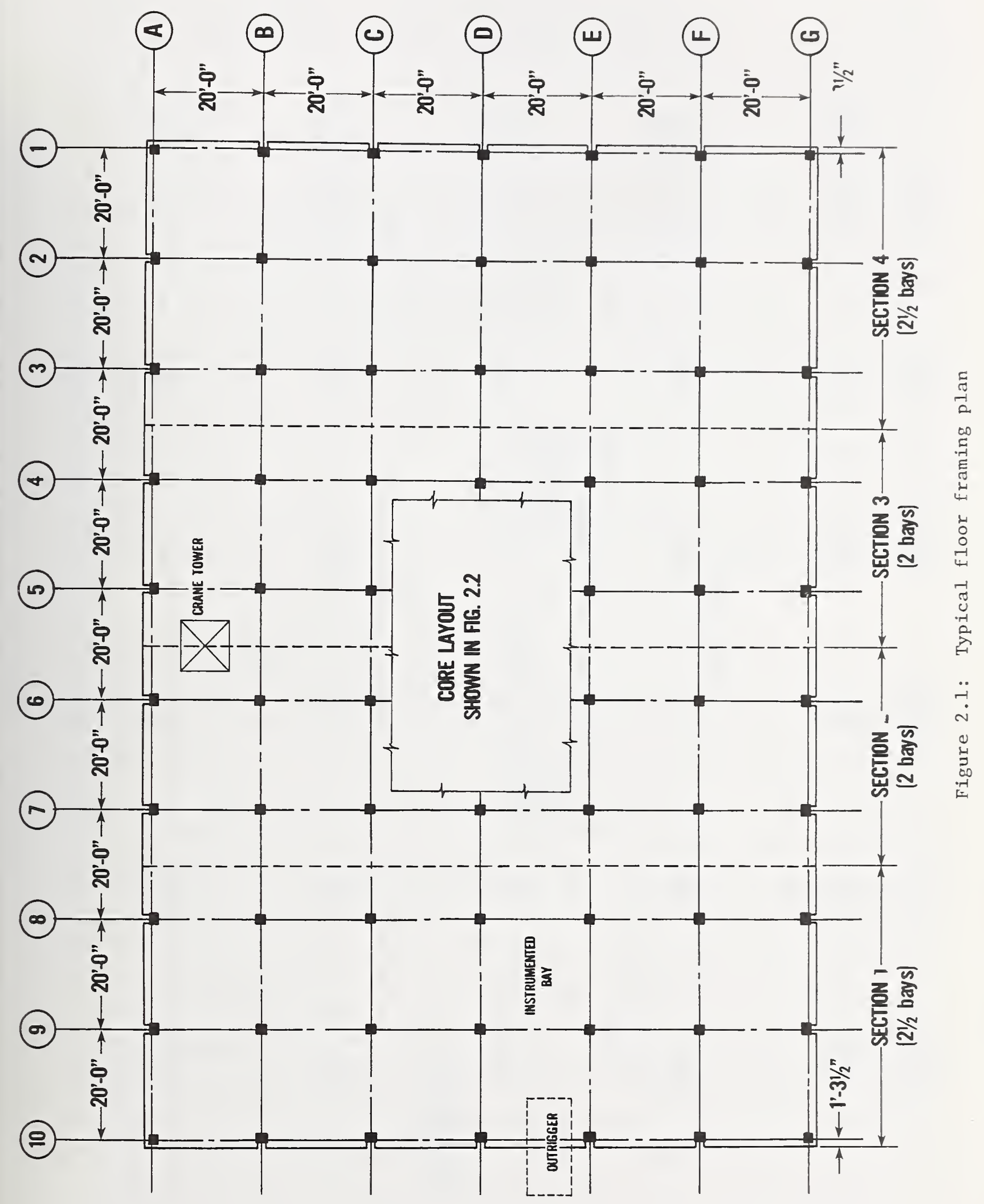




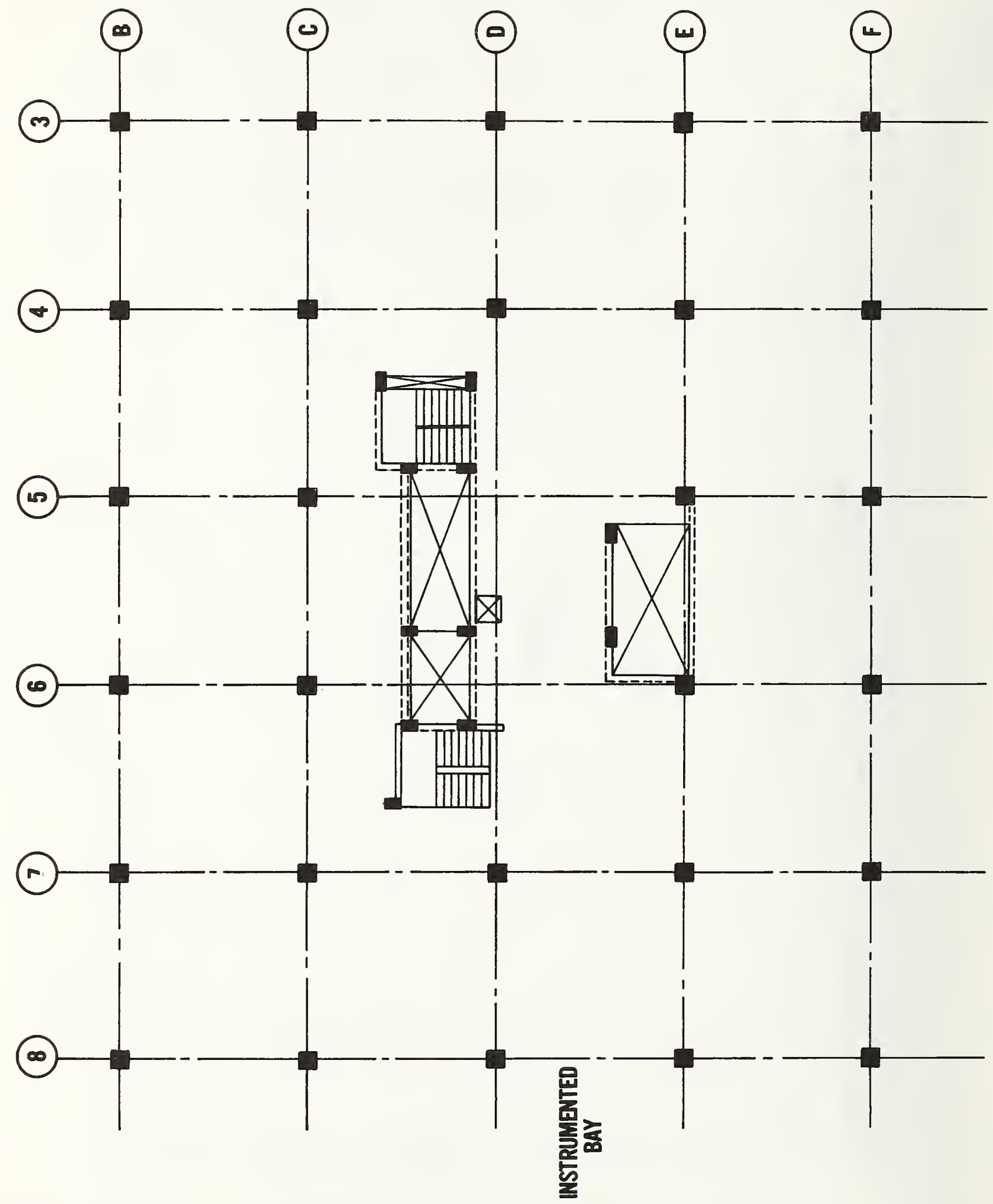

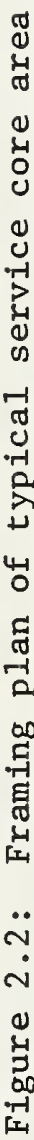




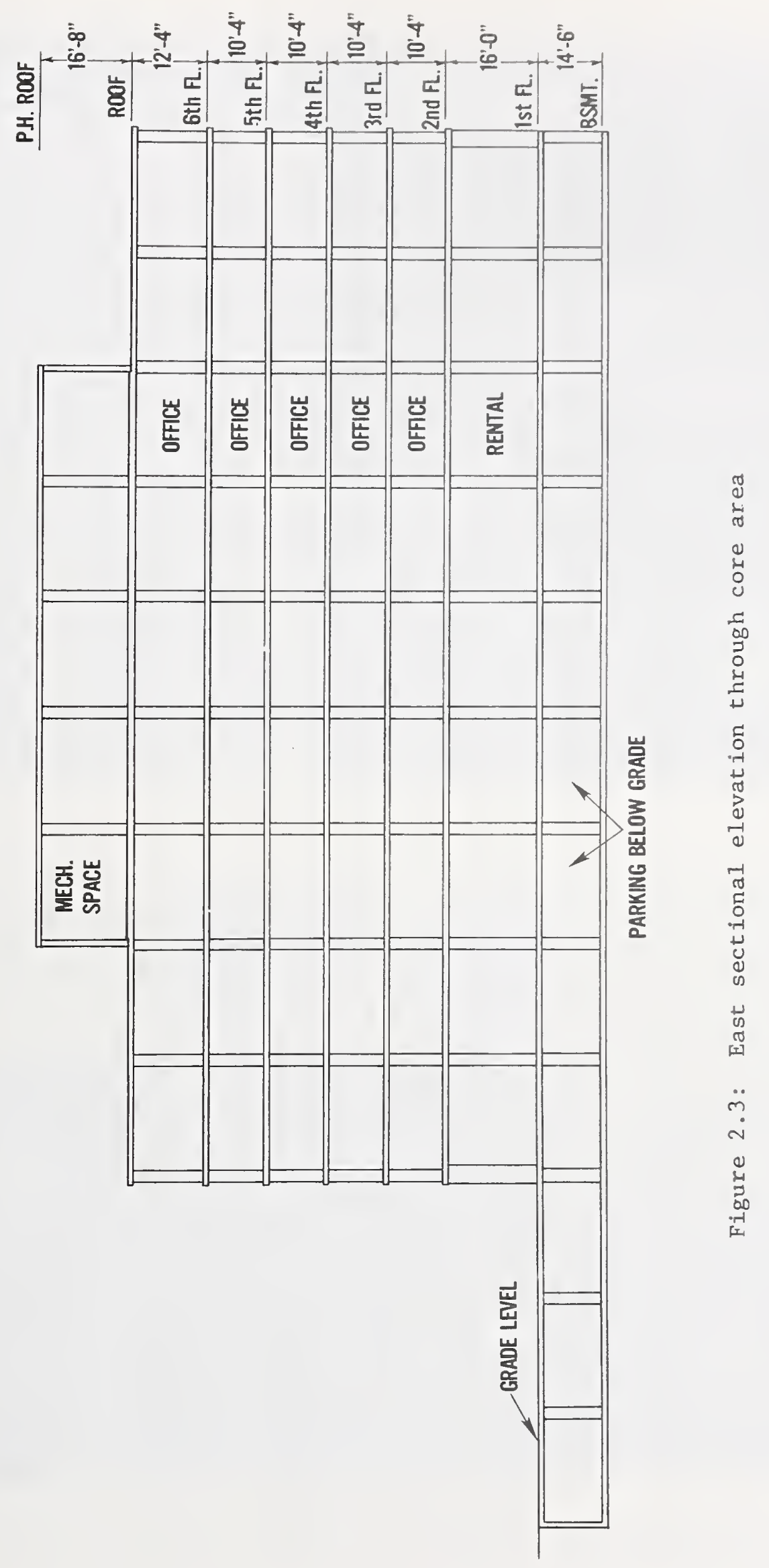




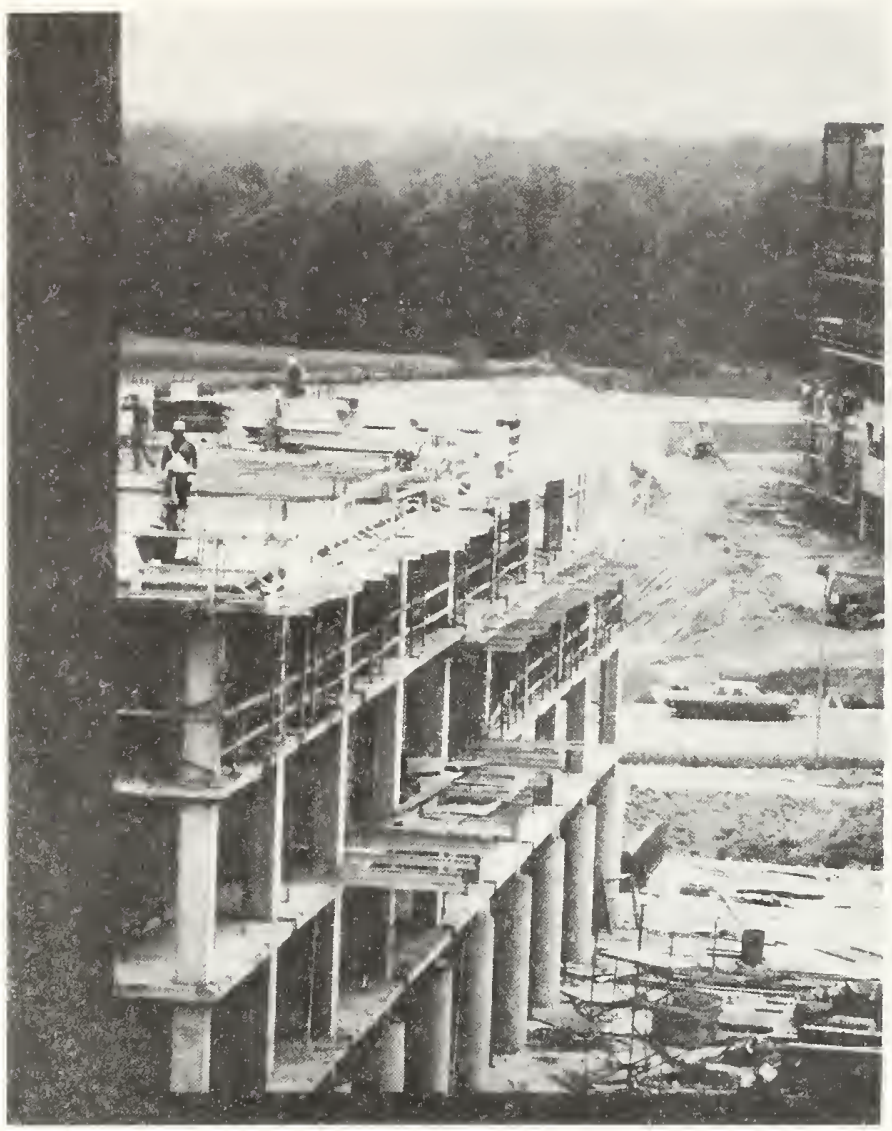

Figure 2.4: Partial view of east end of building

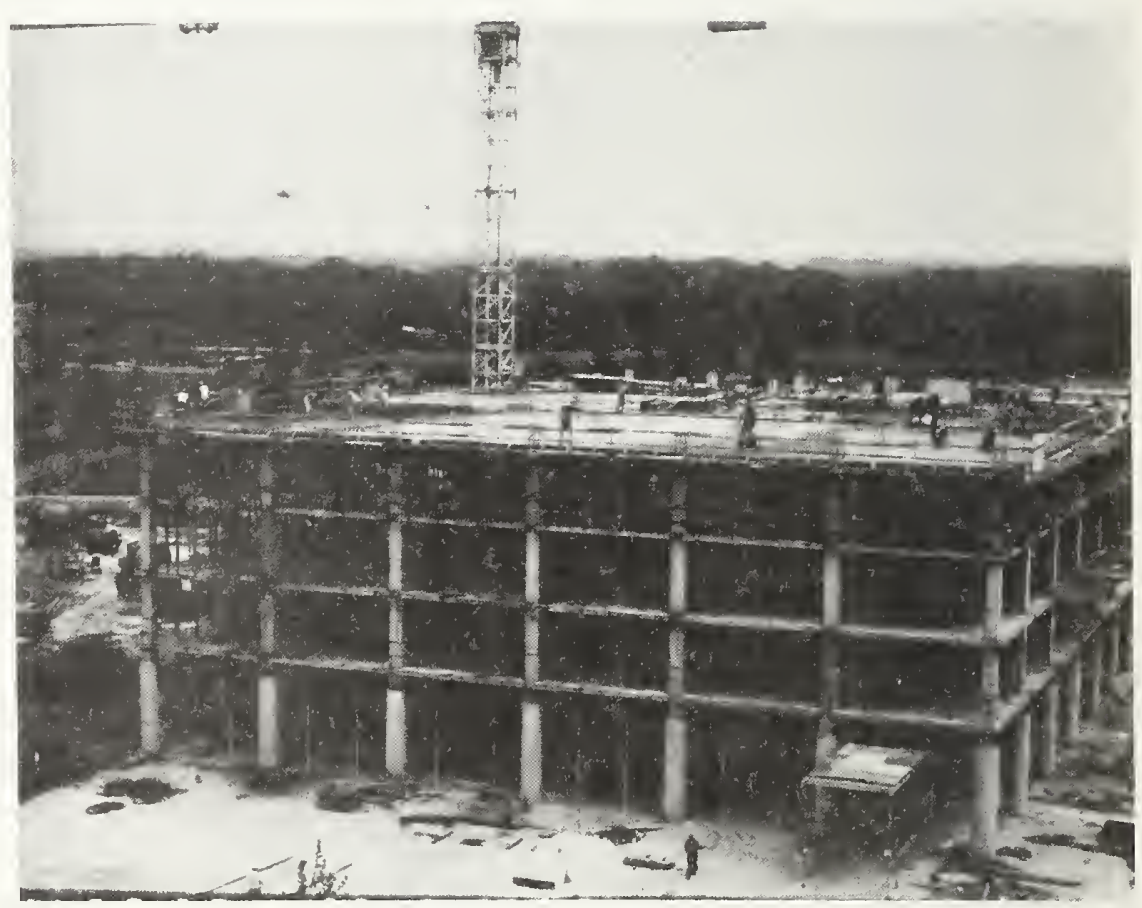

Figure 2.5: View of building at south end 


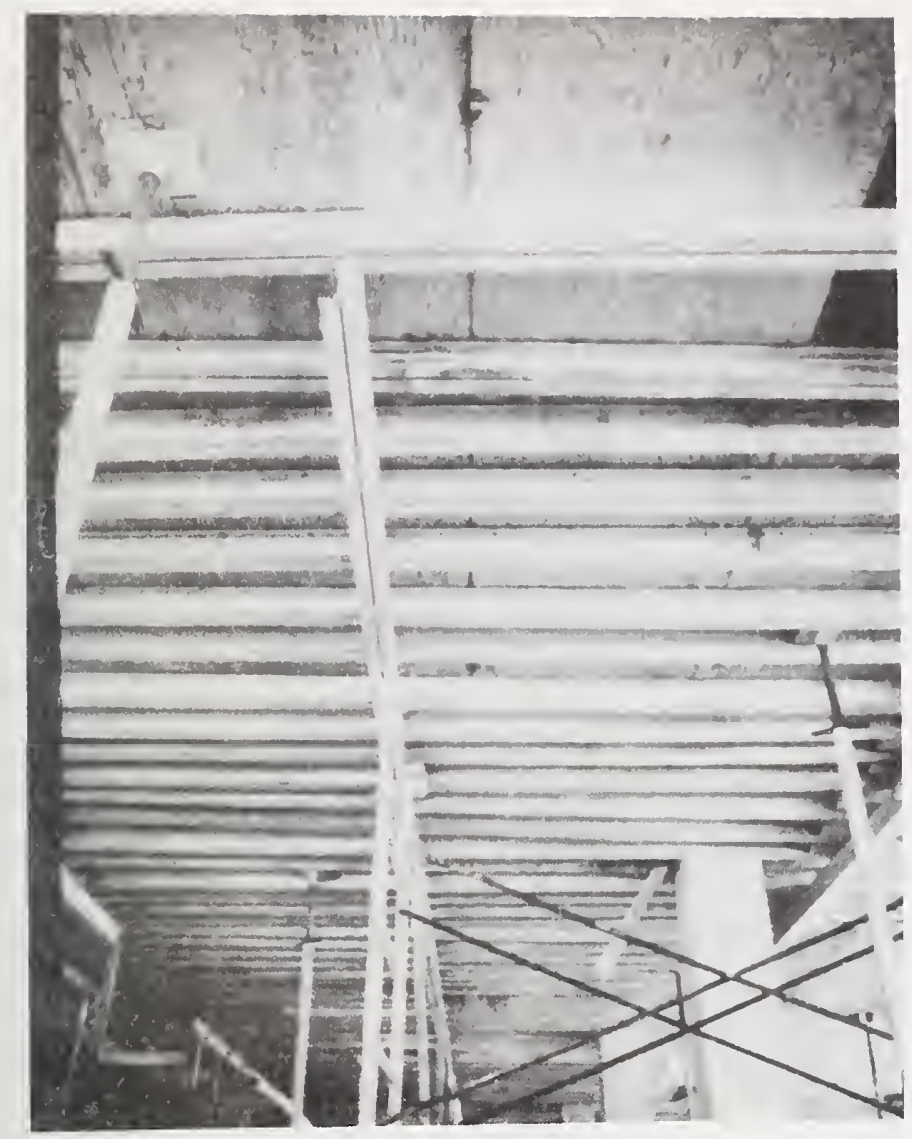

Figure 2.6: Shoring system in first story

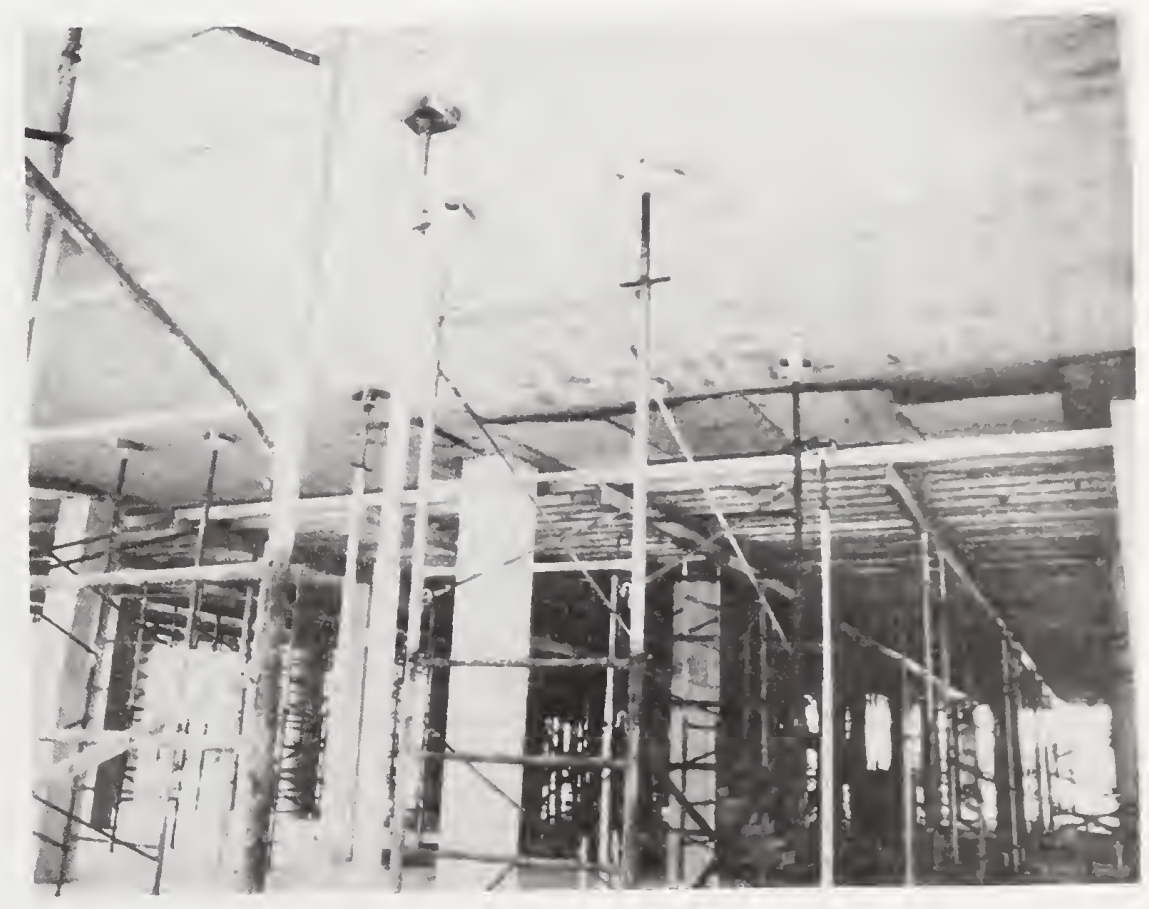

Figure 2.7 Stripping and reshoring in the first story 

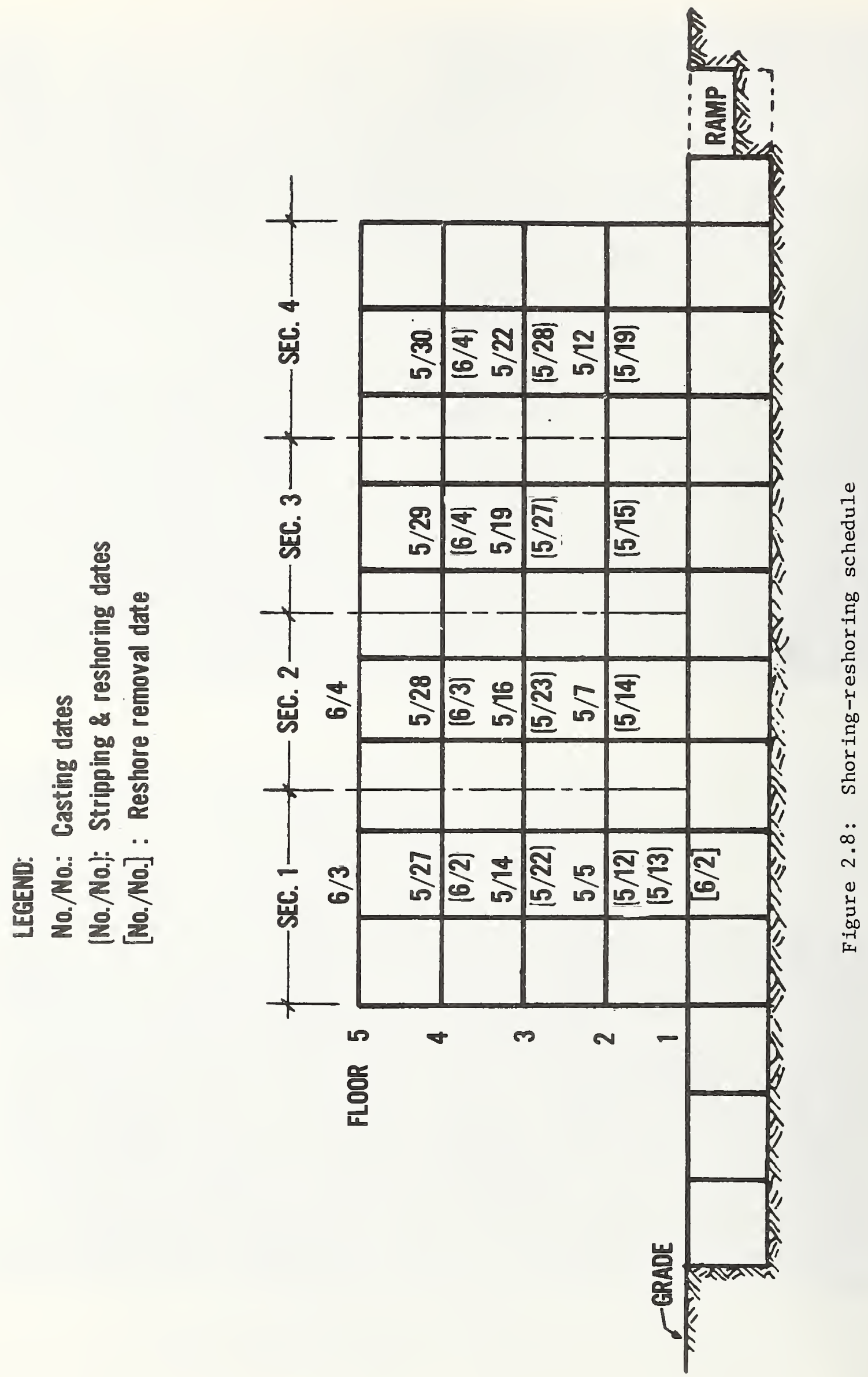


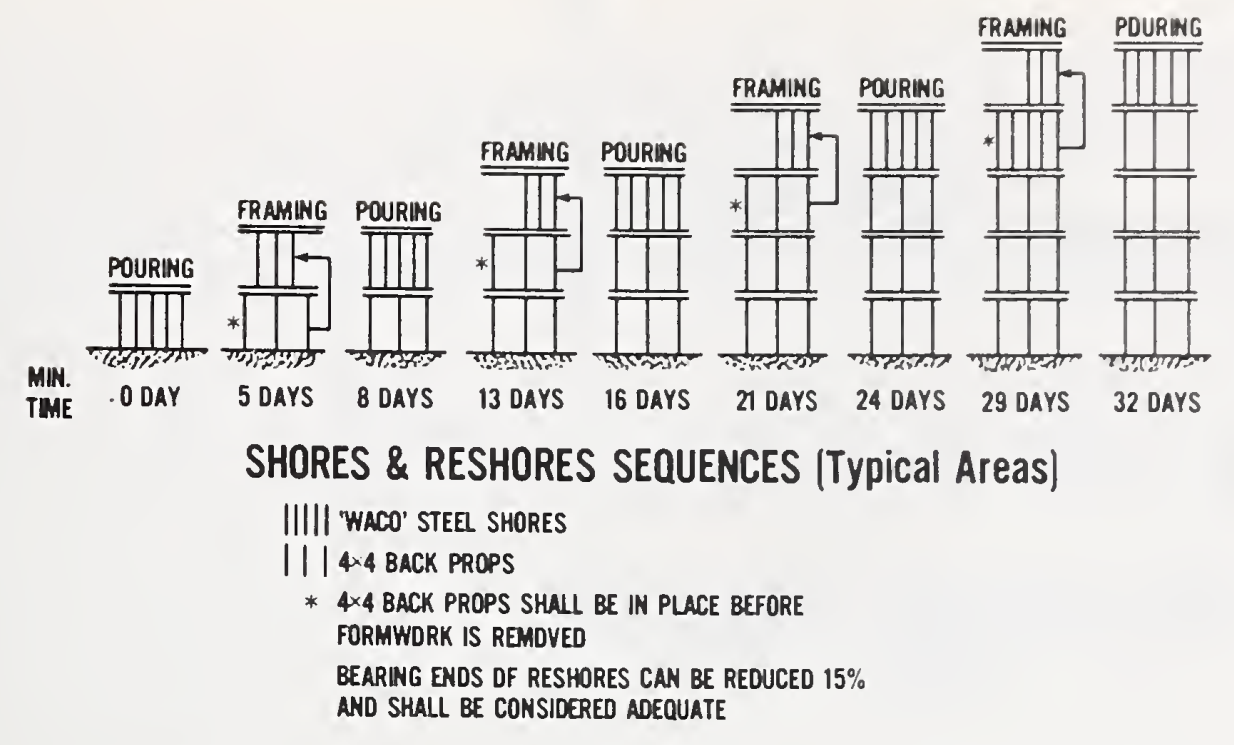

\section{MATERIALS:}

Plywood: $\quad 5 / 8$ " B-B Plyform Class I.

Reshores: $4 \times 4$ wood posts - Southern Pine K.D., No. 2 Grade.

$3 \times 4$ wood posts - Douglas Fir, No. 1 Grade.

Formwork \& Shores: Standard "WACO" shores and standard "ALUMA" Building

Systems Inc. Beams \& Stringers

FORMWORK NOTES

Design Standards Used

The formwork design conforms to the following standards:

A. ACI 347-68.

B. ACI Publication SP-4, Fourth Edition.

C. National Design Specification for Wood Construction - 1977 Ed.

D. Table I - Supplement to 1977 edition of National Design Specification for Wood Construction.

E. Plywood Design Specification published by American Plywood Association in December, 1976.

F. Plywood for Concrete Forming published by American Plywood Association.

G. Various other technical publications and test data.

Shoring and Reshoring

As a minimum requirement during a pouring operation, the section of concrete in the process of being placed shall be supported by the formwork recelving the concrete, plus three (3) lifts of reshores below that section (See Shores \& Reshores Sequence - typical areas).

Removing Formwork \& Reshoring Slab (Typical Areas)

When a pour is at least five (5) days old and field cured cylinders indicate a concrete strength in excess of $75 \%$ of the design strength of $\left(f^{\prime}{ }^{\prime}=3000\right.$ psi (c 28 days) the slab shall first be back-propped and then the horizontal and vertical formwork can be removed. Where the plywood cannot be removed because of the $4 \times 4$ reshores the contractor shall remove the $4 \times 4$ reshores one at a time, lower the plywood, and immediately replace the reshore before removing another reshore. The slab will then be supported by four (4) lifts of $75 \%$ reshores. (See Typical Floor Reshoring Plan). Shores shall remain in place until concrete has achieved $100 \%$ of design strength ( $f^{\prime} \mathrm{c}=3000 \mathrm{psi}$ (e 28 days) and always one (1) lift of formwork and three (3) lifts of reshores beneath any slab to be poured.

Removing Formwork \& Reshoring Slab (High Framing Area Greater than 10'-0")

In areas where the unbraced length of reshores exceeds ten (10) feet contractor shall use WACO heavy duty steel reshores.

Formwork, shores, reshores, bracing, etc. shall comply in every respect with the contract specifications except $100 \%$ reshores may be substituted for shoring as noted in specifications and placed in accordance with these drawings. 


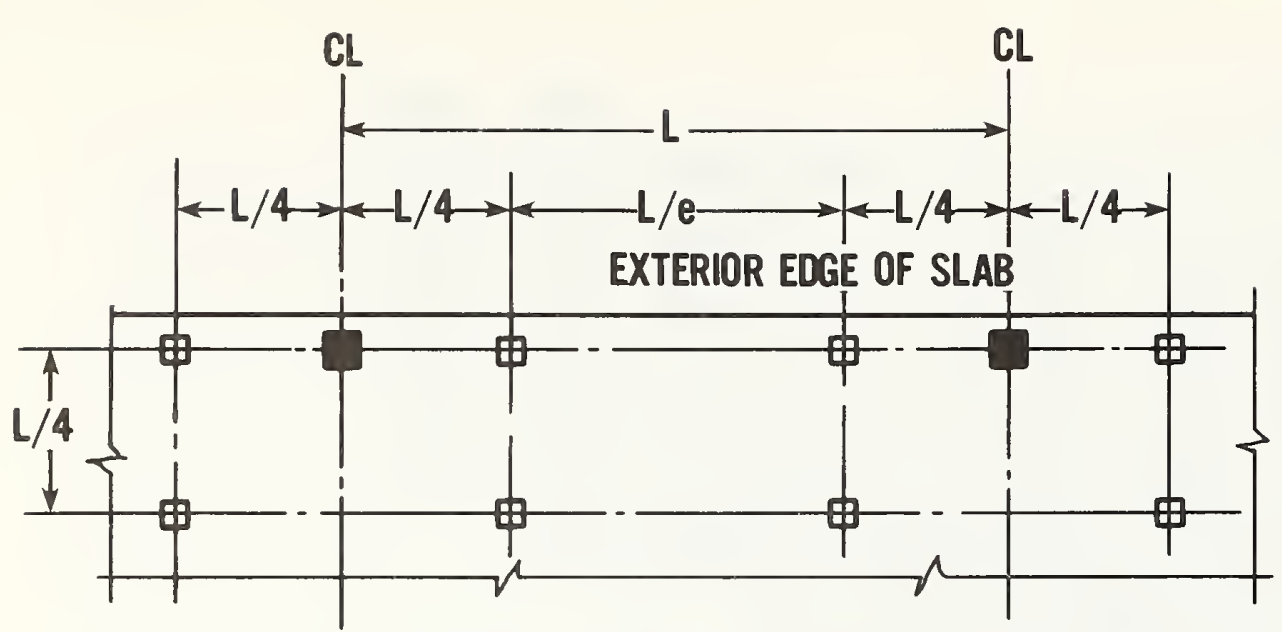

\section{EDGE RESHORE CONDITION}

NO SCALE

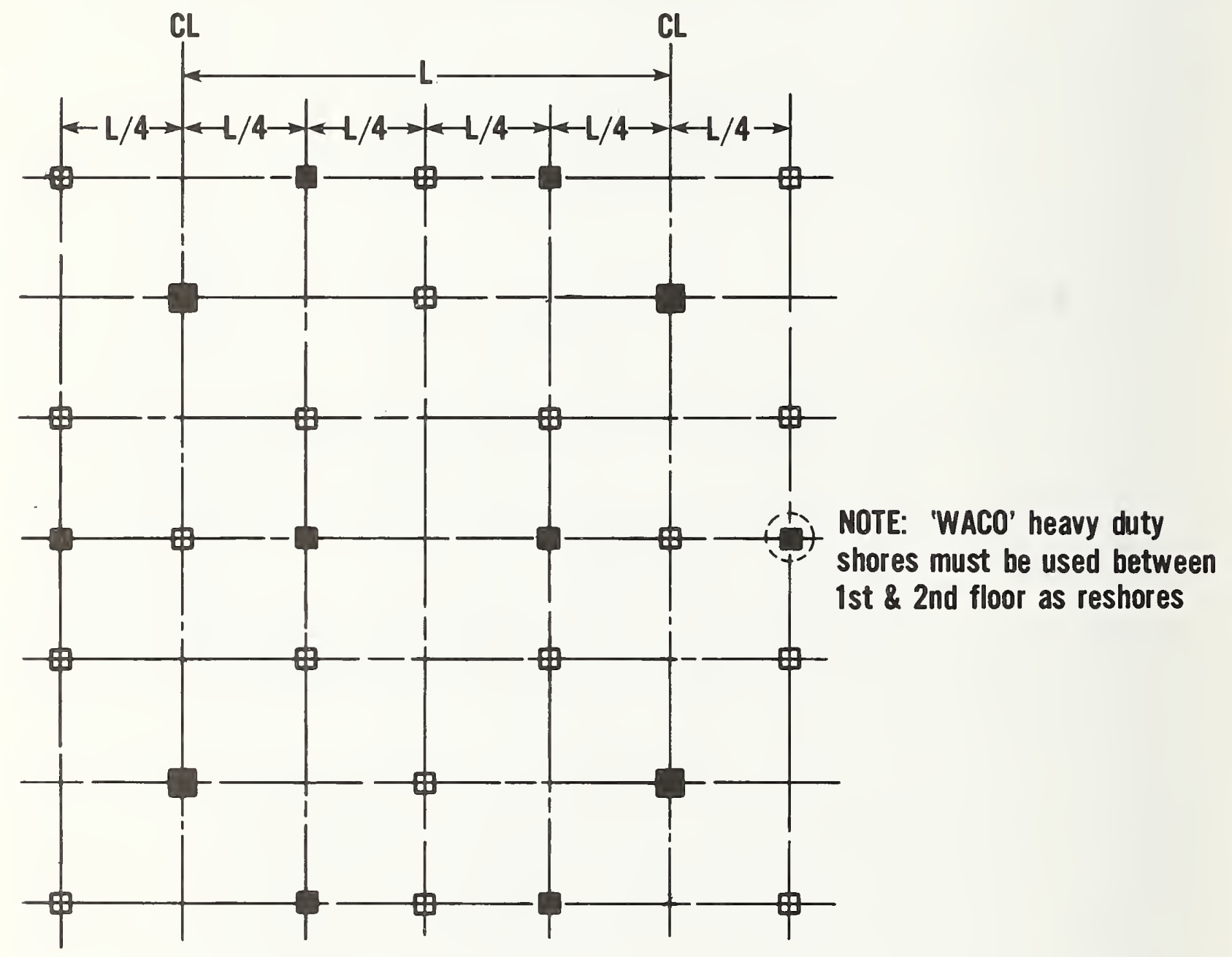

$\square$ 4 4 WOOD RESHORES, OR HEAVY DUTY 'WACO' POST SHORES

75\% RESHORING PLAN (see shores \& reshores sequence for lifts where can be removed)

Figure 2.10: Reshoring plan 


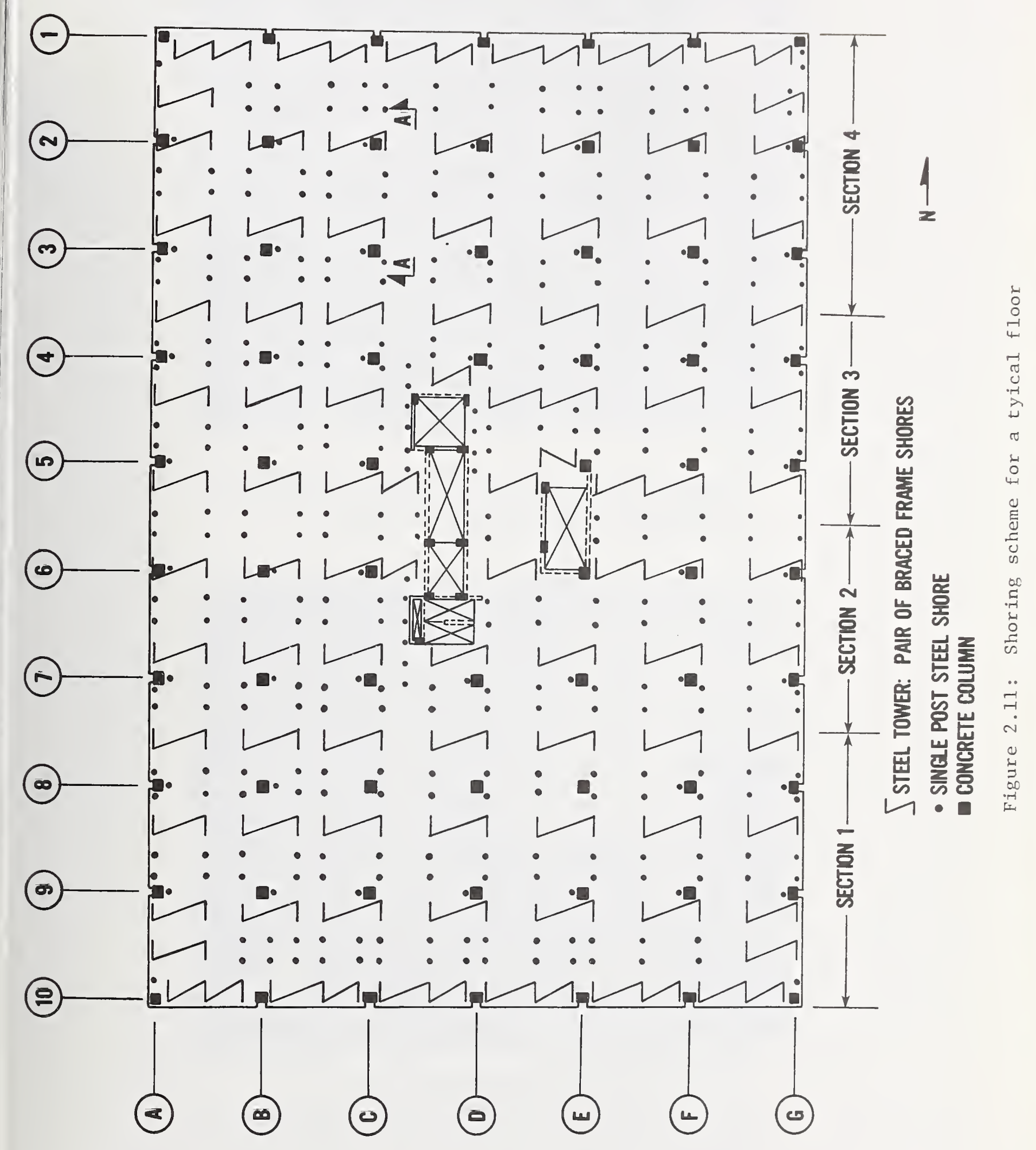




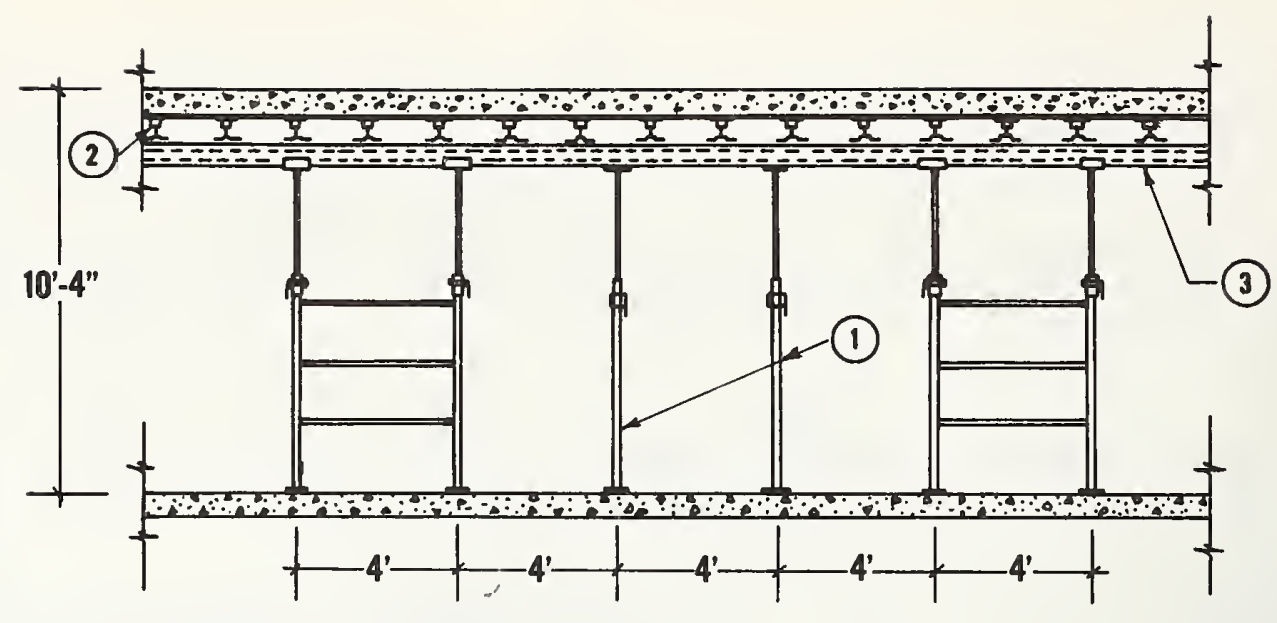

Notes

1. Indicates 0701-89 Post Shore

2. Indicates ALUMA Joist

3. Indicates ALUMA Stringer

\section{General Notes}

Safe allowable loads have been determined through field and laboratory tests carried out by independent engineering firms. The capacities shown are based on safety factors as noted.

\section{Equipment}

1. Heavy duty scaffolding used in this project to have a nominal capacity of $10,0001 \mathrm{bs}$. per leg and to be used in accordance with this drawing and manufacturer's specification. (for garage)(if applicable).

2. Vertical shores to be ACROW type size 12 or equivalent.

3. Aluminum beams to be as per ALUMA-SYSTEMS section 35020 .

Lumber

4. All lumber stresses are in accordance with CSA Standard 086-1970 with allowance of $25 \%$ for short term loading for $4 \times 6$ and $2 \times 10$ and $25 \%$ for short term loading plus $10 \%$ for load sharing members for $4 \times 4$. Grade is structural no. 2 .

Working Stresses Used:

$$
\begin{aligned}
& \frac{4 \times 4}{1800 \text { p.s.i. }} \\
& \begin{array}{l}
150 \text { p.s.i. } \\
1.76 \times 106 \text { p.s.i. }
\end{array}
\end{aligned}
$$$$
\text { Bending }
$$$$
\text { Horizontal Shear }
$$$$
\text { Modulas of Elasticity }
$$

P1ywood to be $11 / 16^{\prime \prime}$ concrete grade B.C. fir S2S.

\section{Loads}

5. Live load assumed 50 psf. Dead load $150 \mathrm{pcf}$.

6. Capacity of ALUMA-Systems' beam is $3001 \mathrm{bs}$. per 1inear foot (nominal).

7. Design limit for reflection is SPAN/360.

\section{Miscellaneous Notes:}

8. All scaffolding and shoring to be effected plumb and level.

9. All splices in lumber joists and stringers to be over their supports.

10. Face grain of plywood to run at right angle to support.

11. Lumber shall be as specified and free of large knots and visible defects.

12. Joists and stringers consisting of two or more members shall be nailed, bolted or clamped together.

13. All base plates to be nailed to sills.

14. All stringers in U-Heads to be centrally placed, wedged, equally packed from both sides and securely nailed. Butt joints in stringers shall be directly over frame legs.

15. This shoring is not designed for motorized equipment.

16. Reshoring, if required, is the responsibility of the contractor.

17. Sills or sleepers to be $2 \times 8 \mathrm{~min}$. on concrete slab and $2-2 \times 8$ on grade.

18. Scaffold and shoring shall be erected in accordance with the approved drawing.

19. ALUMA Building Systems, Inc. must be notified of any changes to or deviations from this drawing.

\section{Figure 2.12: Shoring profile and specifications}




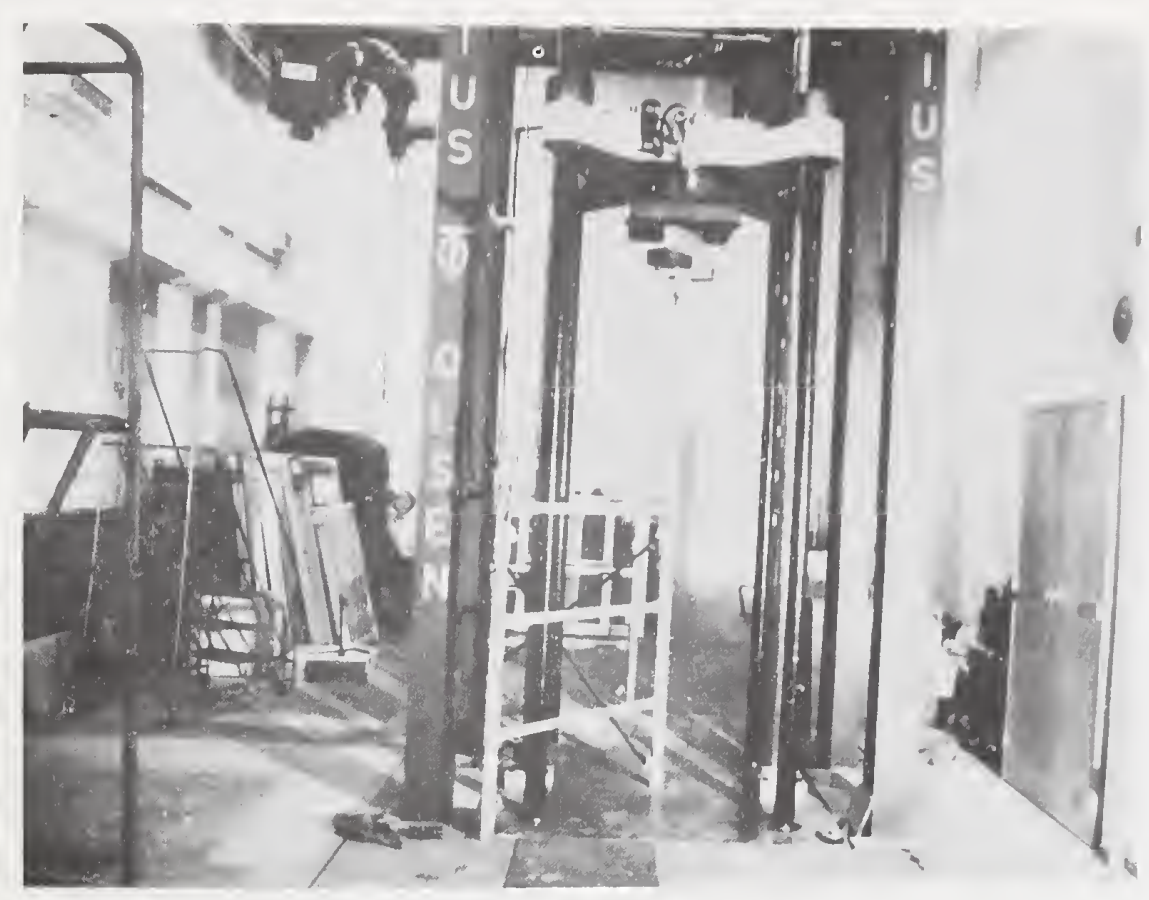

Figure 2.13 Calibration of frame shore columns

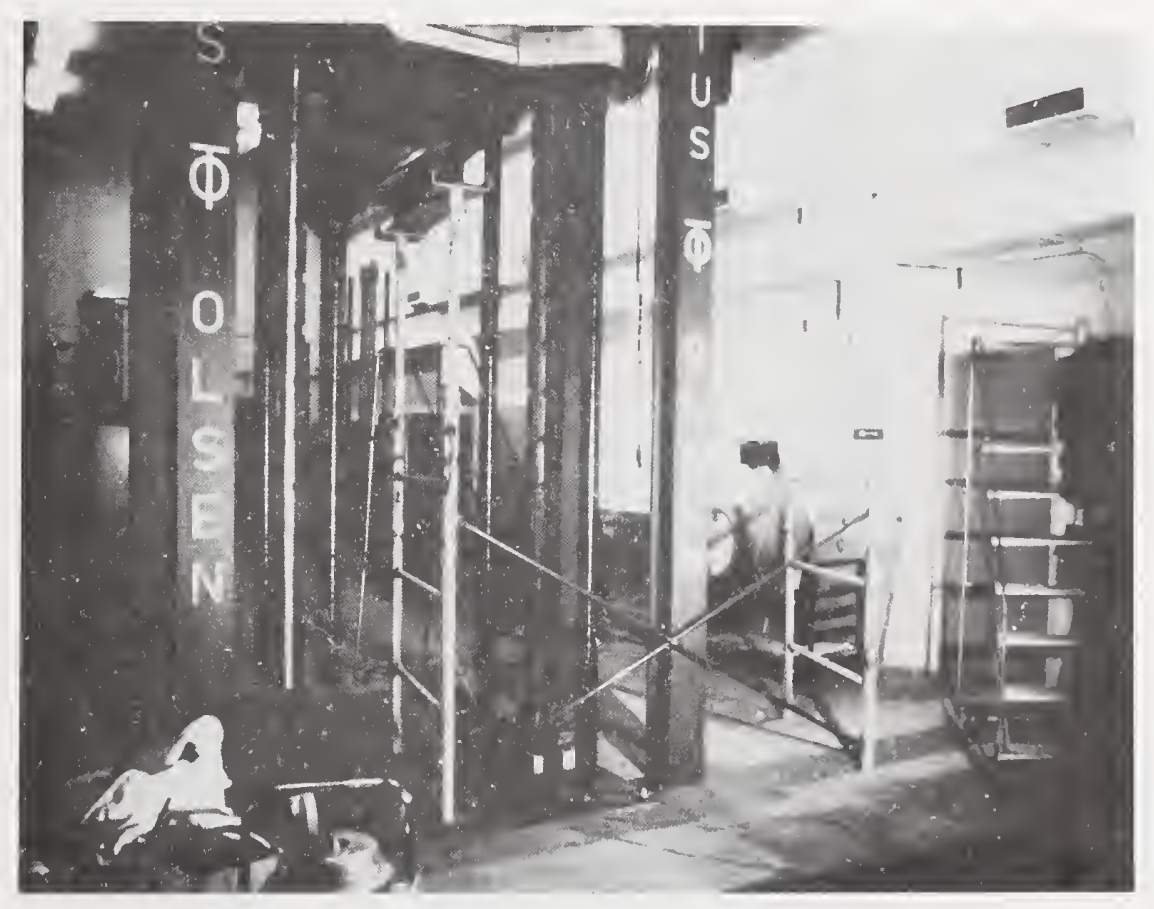

Figure 2.14: Calibration of frame shore 


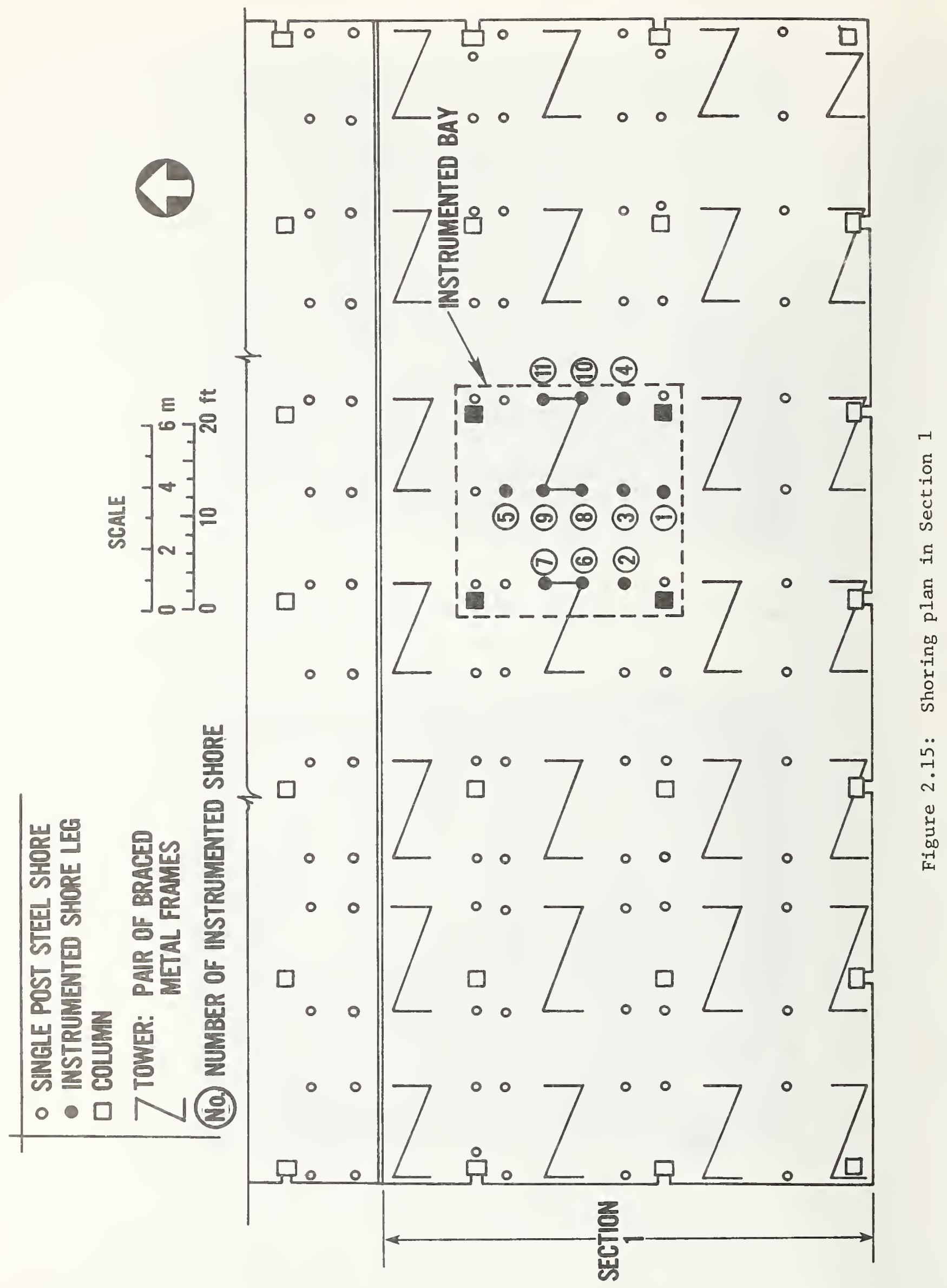




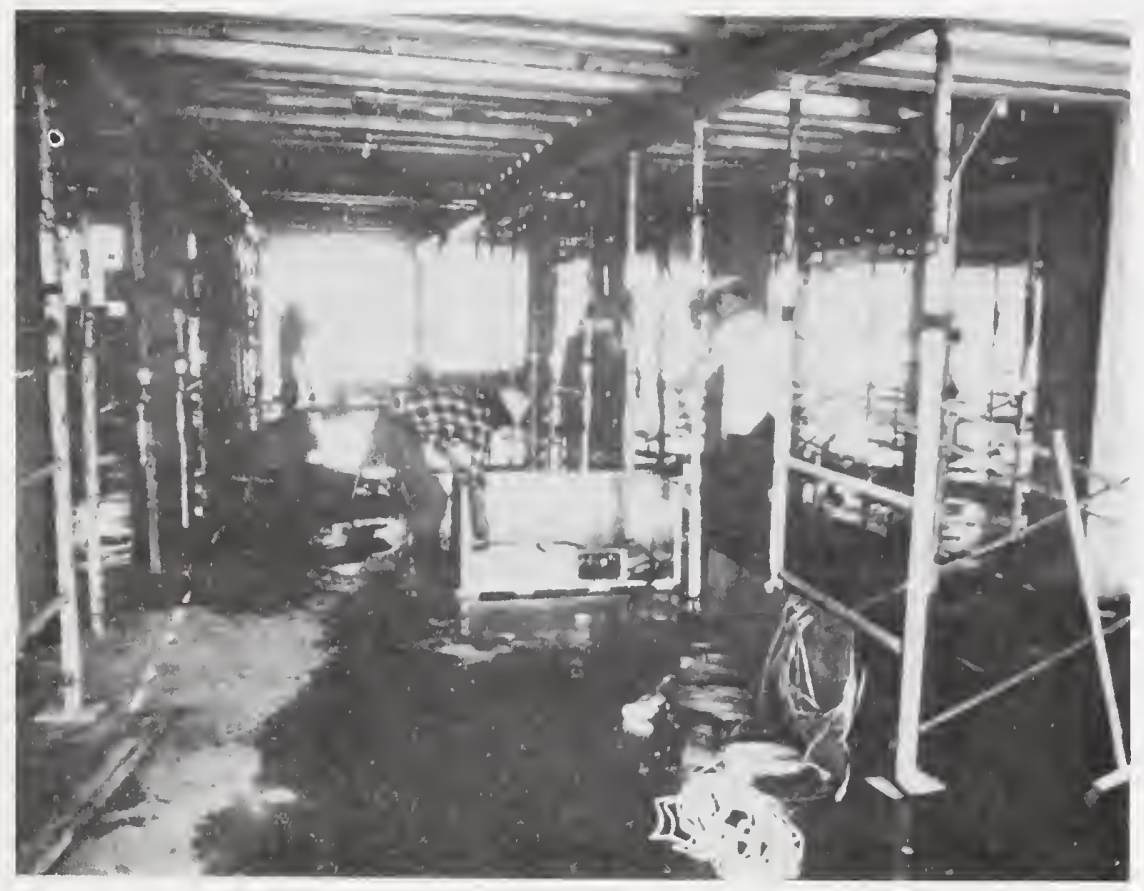

Figure 2.16: Instrumentation in third story deck.

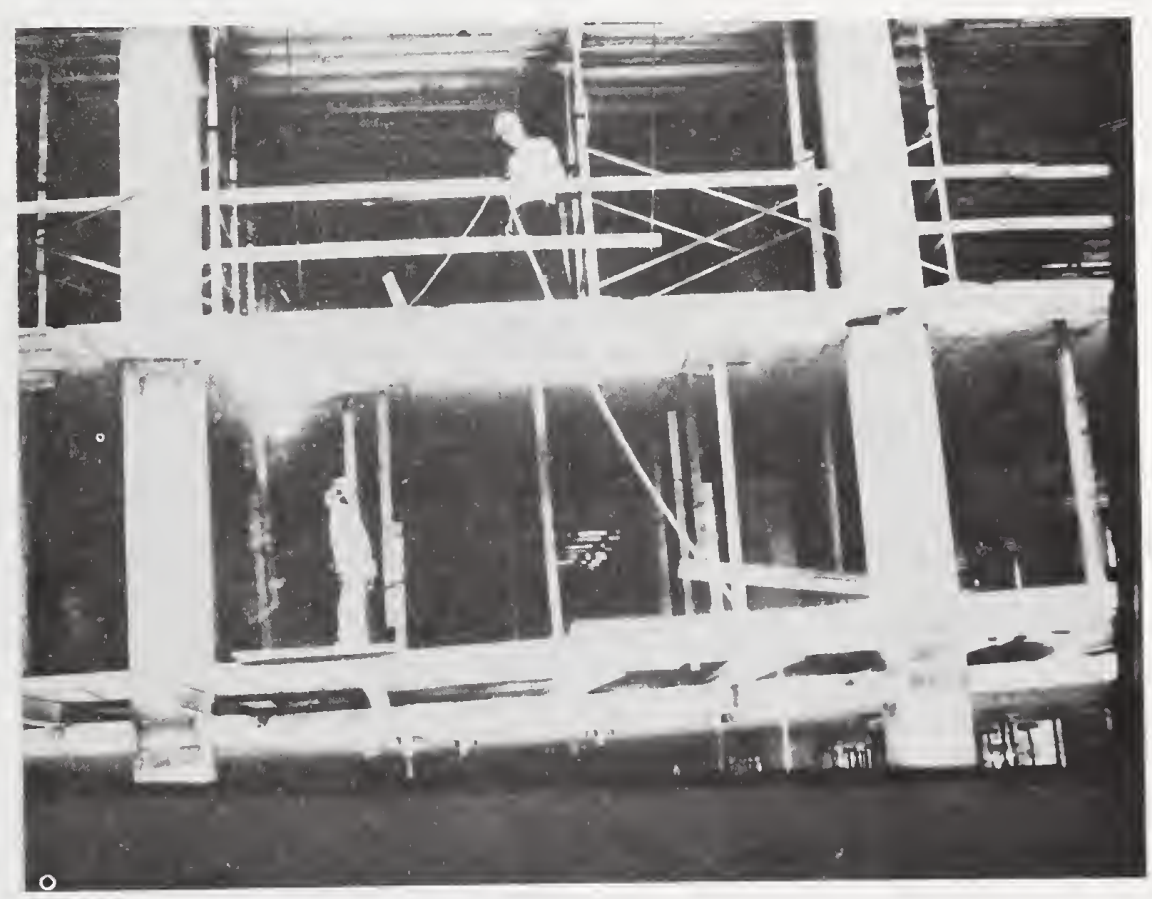

Figure 2.17: Installation of lead cables to on-site recorder. 


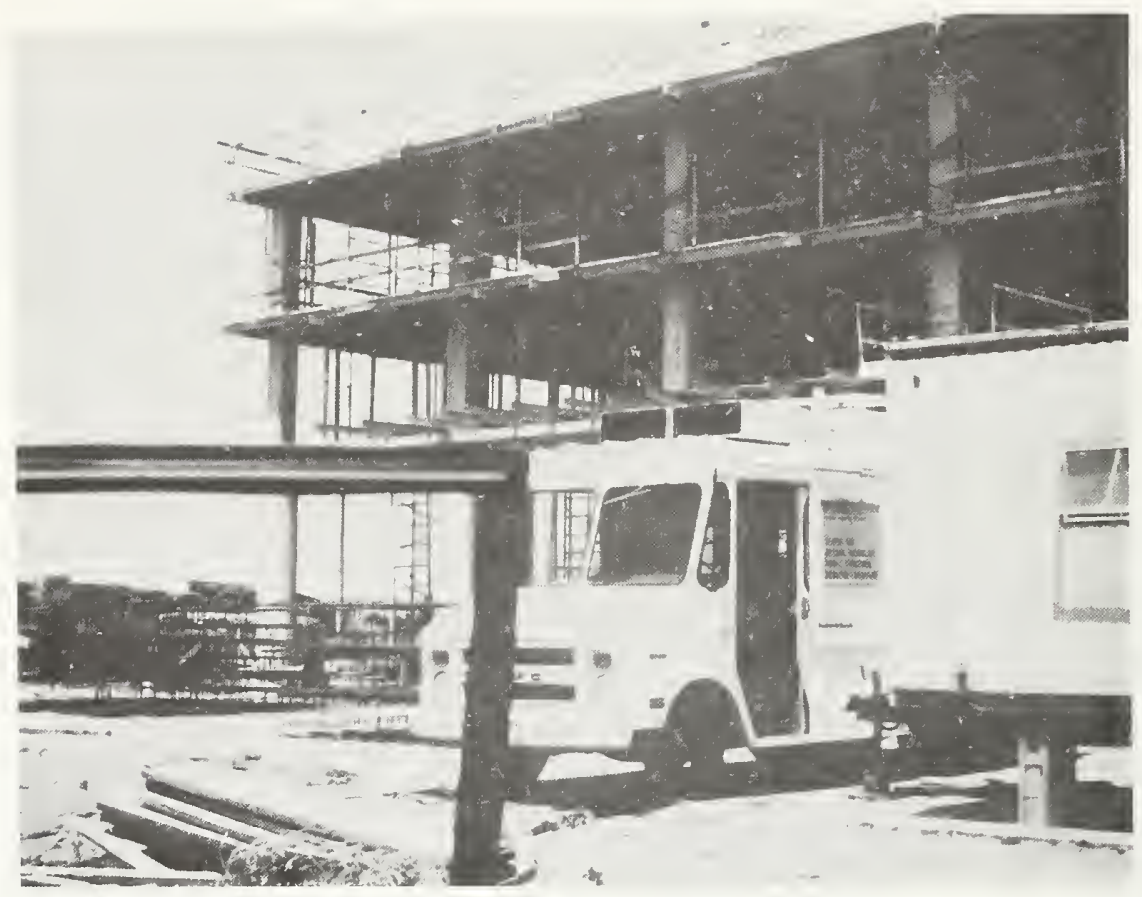

Figure 2.18: Location of mobile van housing data acquisition system

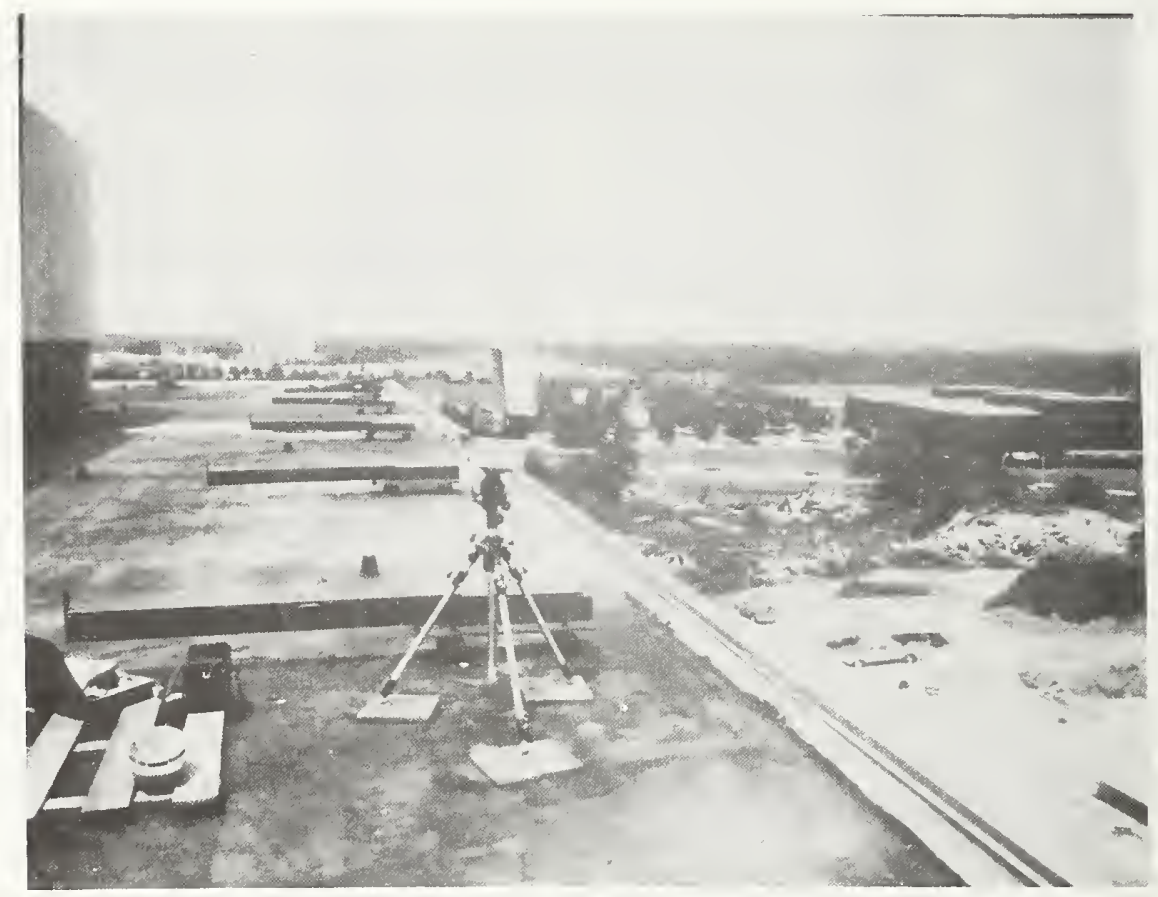

Figure 2.19: Location of time lapse camera. 


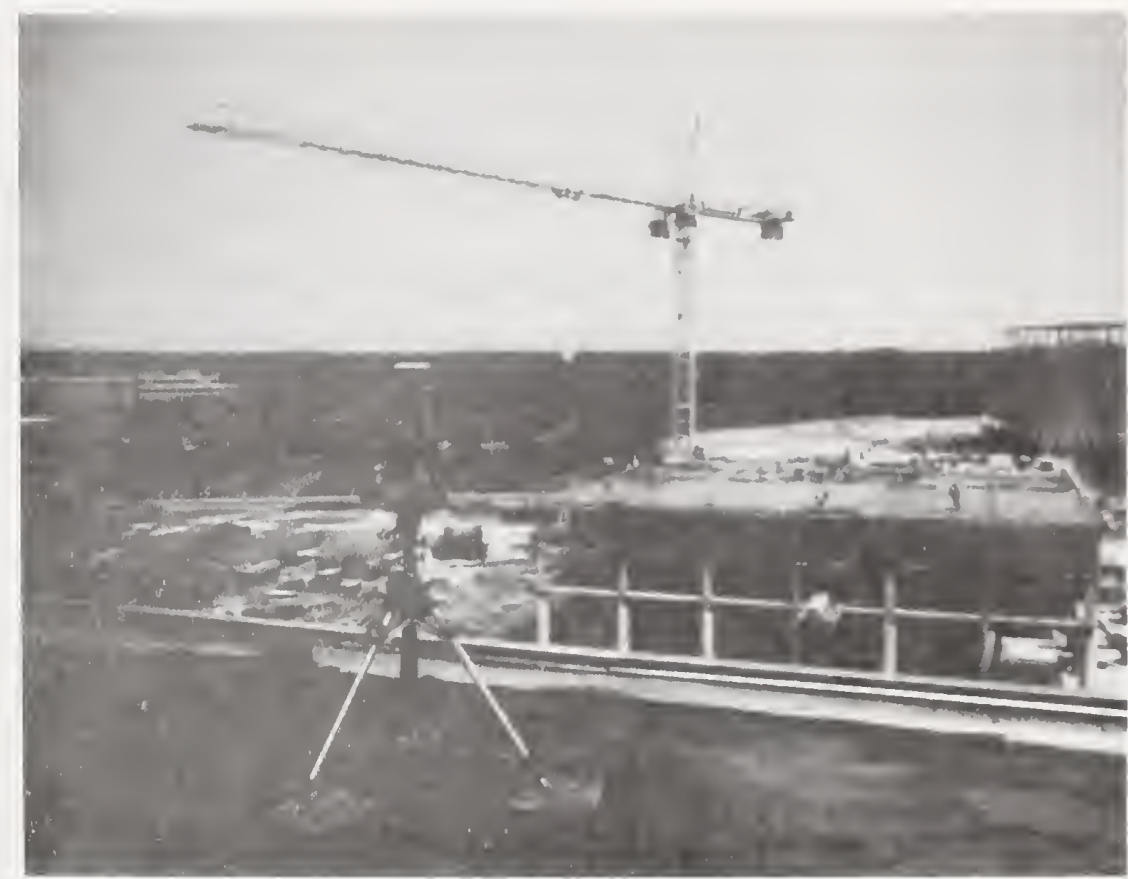

Figure 2.20: Construction site viewed from roof of adjacent building.

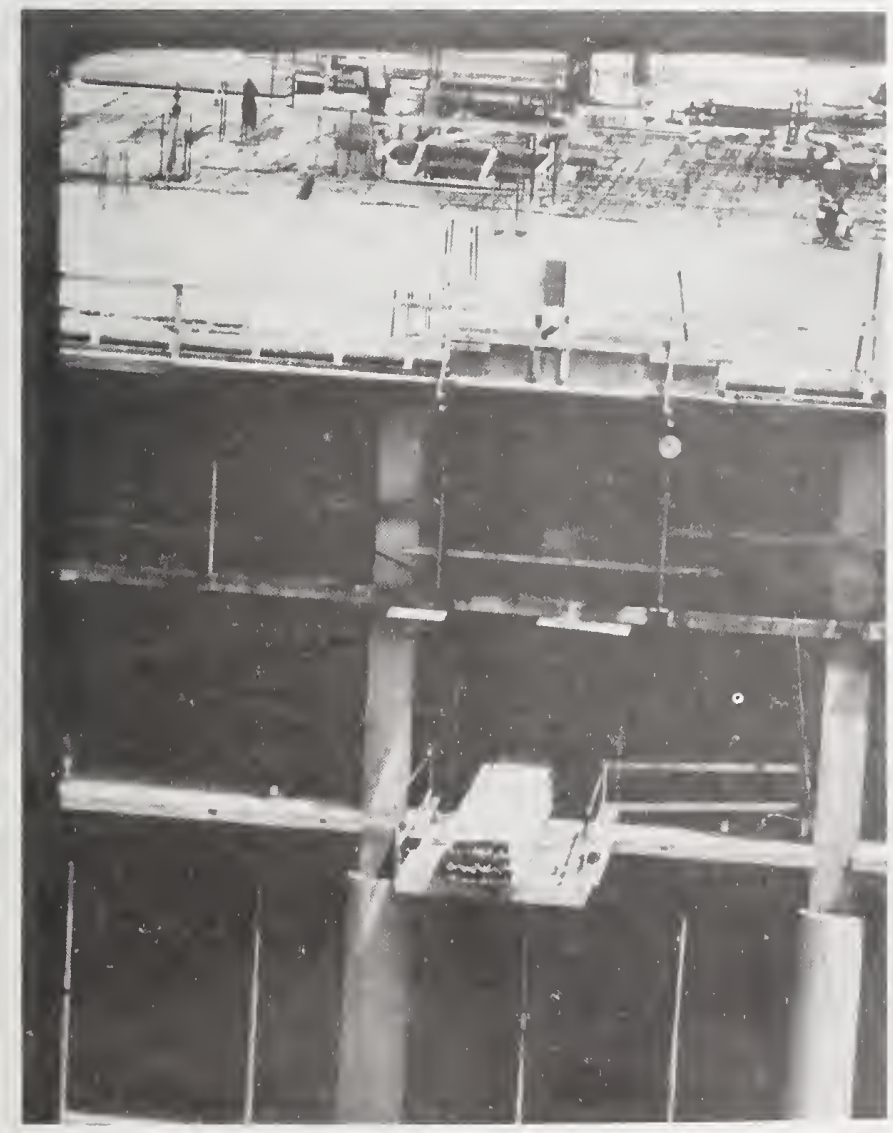

Figure 2.21: Partial close-up view of south end. 


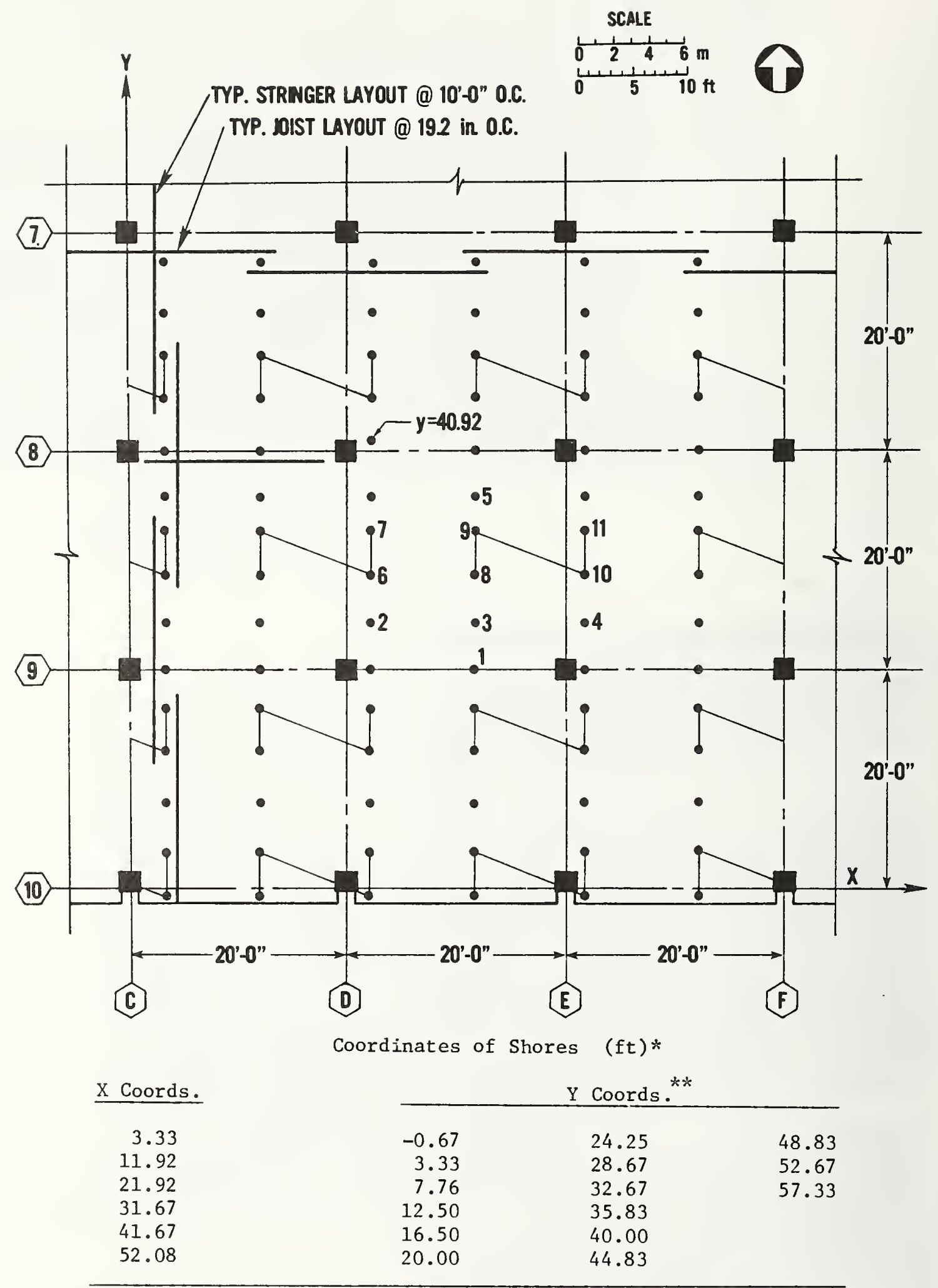

$* 1.0 \mathrm{ft}=0.305 \mathrm{~m}$

$* *$ Except as noted in sketch

Figure 2.22: Third story shores 


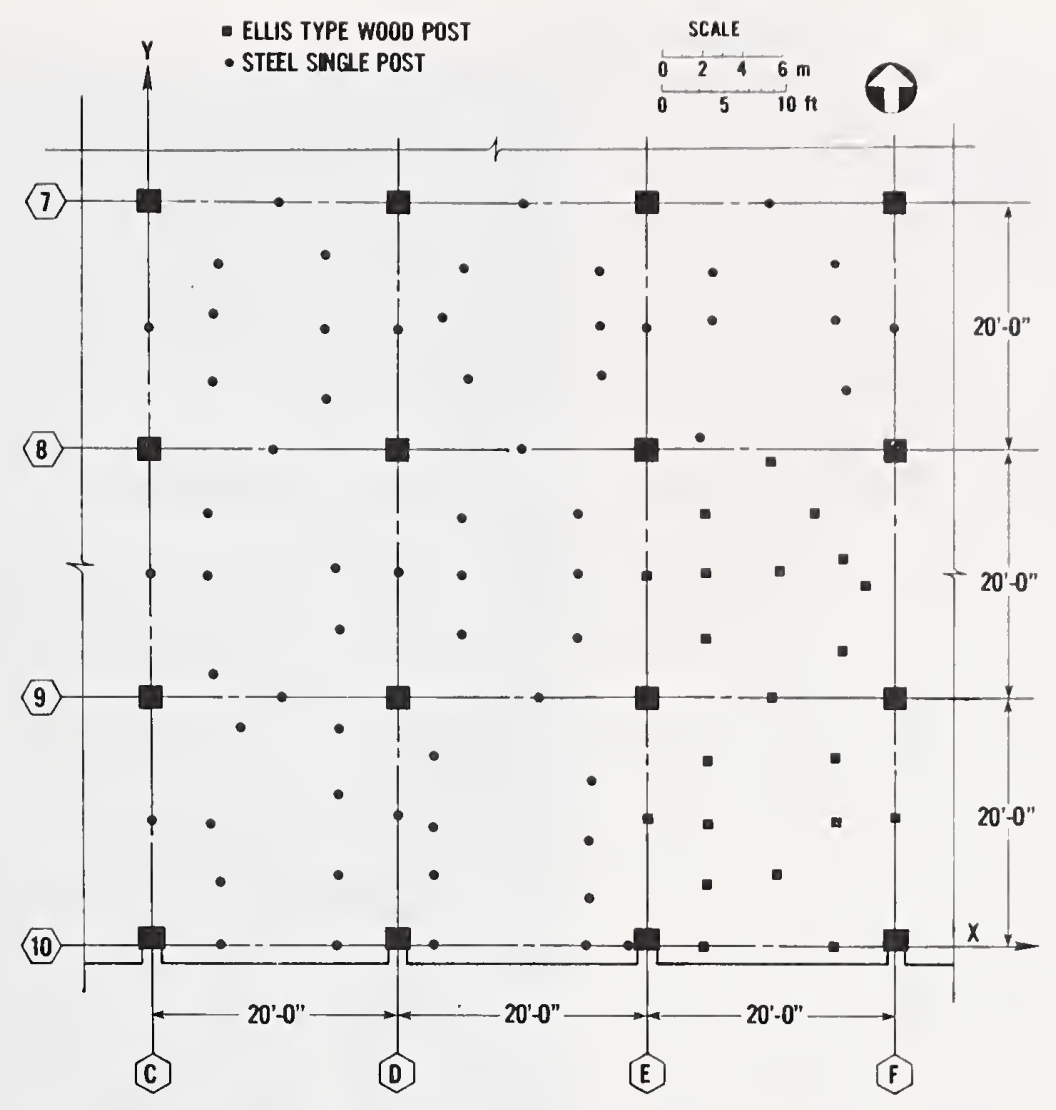

Coordinates of second story reshores

\begin{tabular}{|c|c|}
\hline Row & $(x, y)$ in $\mathrm{ft}$. , rows in order of increasing $y$ \\
\hline Line $\mathrm{C}$ & $(0.00,10.00)(0.00 .29 .92)(0.00,49.92)$ \\
\hline w. Line & $\begin{array}{l}(5.50,0.00)(5.50,5.08)(4.75,9.83)(7.17,15.58) /(5.00,21.83) \\
(4.25,29.83)(4.25,34.83) /(5.08,44.58)(5.25,50.00)(5.75,55.00)\end{array}$ \\
\hline Midspan & $(10.67,20.00)(10.00,40.00)(10.33,60.00)$ \\
\hline E. Line & $\begin{array}{l}(15.00,0.00)(15.00,5.75)(15.00,10.25)(15.00,15.58) / \\
(15.33,25.42)(14.50,30.25) /(14.25,44.17)(14.25,49.83) \\
(14.25,54.75)\end{array}$ \\
\hline Line $\mathrm{D}$ & $(20.00,10.41)(20.00,30.17)(20.00,49.75)$ \\
\hline w. Line & $\begin{array}{l}(22.83,0.00)(22.83,5.67)(22.83,9.50)(22.83,9.50)(22.83,15.25) / \\
(25.17,25.08)(25.17,29.92)(25.17,34.58) /(25.67,45.67) \\
(23.42,49.75)(25.33,54.67)\end{array}$ \\
\hline Midspan & $(31.33,20.00)(30.08,40.00)(30.08,40.00)$ \\
\hline E. Line & $\begin{array}{l}(35.00,0.00)(35.25,3.75)(35.50,8.50)(35.50,13.25) /(34.50,24.67) \\
(34.50,29.92)(34.50,34.75) /(36.25,45.00)(36.25,50.00) \\
(36.25,54.42)\end{array}$ \\
\hline Line $\mathrm{E}$ & $(38.50,0.00)(40.00,10.25)(40.00,29.82)(40.00,29.83)$ \\
\hline w. Line & $\begin{array}{l}(44.58,0.00)(44.92,4.92)(44.92,9.92)(44.92,14.92) /(44.75,24.75) \\
(44.75,30.00)(44.75,34.83) /(44.42,40.92)(44.67,50.33) \\
(44.67,54.33)\end{array}$ \\
\hline Midspan & $(50.42,5.75)(50.00,20.00)(50.00,39.08)(49.92,60.00)$ \\
\hline E. Line & $\begin{array}{l}(55.08,0.00)(55.25,10.17)(55.25,15.25) /(55.83,23.67) \\
(57.50,29.00)(55.83,31.17)(53.58,34.83) /(58.00,45.00) \\
(55.25,50.58)(55.25,55.17)\end{array}$ \\
\hline Line $F$ & $(60.00,10.33)(60.00,49.83)$ \\
\hline
\end{tabular}

NOTE: $1.0 \mathrm{ft} .=0.305 \mathrm{~m}$.

Figure 2.23: Second story reshores 


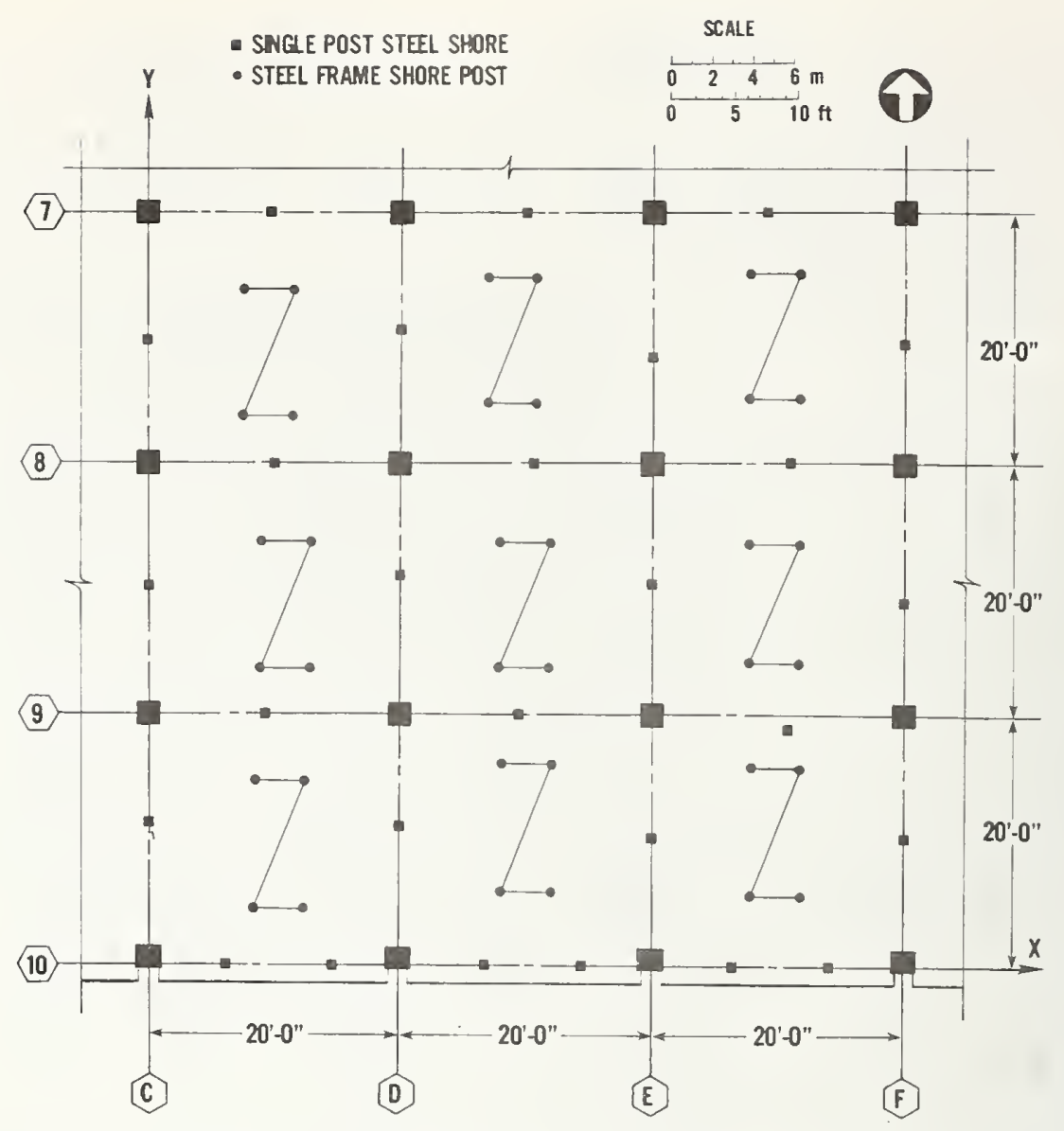

Coordinates of first story reshores

\begin{tabular}{|c|c|}
\hline Row & $(\mathrm{x}, \mathrm{y})$ in $\mathrm{ft}$. , rows in order of increasing $\mathrm{x}$ \\
\hline Line 10 & $\begin{array}{l}(6.00,0.00)(14.50,0.00)(26.75,0.00)(33.58,0.00) \\
(46.33,0.00)(54.00,0.00)\end{array}$ \\
\hline S. Frame & $\begin{array}{l}(8.25,4.42)(12.25,4.42)(28.17,5.83)(32.17,5.83) \\
(47.75,5.67)(47.75,5.67)(51.75,5.67)\end{array}$ \\
\hline Midspan & $(0.00,10.67)(20.00,11.08)(40.00,10.17)(60.00,10.17)$ \\
\hline N. Frame & $\begin{array}{l}(8.25,14.50)(12.25,14.50)(28.17,15.92)(32.17,15.92) \\
(47.75,15.75)(51.75,15.75)\end{array}$ \\
\hline Iine 9 & $(10.17,20.00)(29.42,20.00)(50.83,18.75)$ \\
\hline S. Frame & $\begin{array}{l}(8.83,23.67)(12.83,23.67)(27.92,23.75)(31.92,23.75) \\
(47.67,24.17)(51.67,24.17)\end{array}$ \\
\hline Midspan & $(0.00,30.17)(20.00,11.08)(40.00,10.42)(60.00,9.92)$ \\
\hline N. Frame & $\begin{array}{l}(8.83,33.75)(12.83,33.75)(27.92,33.83)(31.92,33.83) \\
(47.67,34.25)(51.67,34.25)\end{array}$ \\
\hline Line 8 & $(9.83,40.00)(31.00,40.00)(50.83,40.00)$ \\
\hline S. Frame & $\begin{array}{l}(7.58,43.75)(11.58,43.75)(26.92,44.33)(47.67,45.17) \\
(51.67,45.17)\end{array}$ \\
\hline Midspan & $(0.00,9.75)(0.00,10.58)(0.00,8.42)(0.00,9.58)$ \\
\hline N. Frame & $\begin{array}{l}(7.58,53.83)(11.58,53.83)(26.92,54.83)(30.92,54.83) \\
(47.67,55.25)(51.67,55.25)\end{array}$ \\
\hline Line 7 & $(9.75,60.00)(30.00,60.00)(49.08,60.00)$ \\
\hline
\end{tabular}

NOTE: $1.0 \mathrm{ft} .=0.305 \mathrm{~m}$.

Figure 2.24: First story reshores 


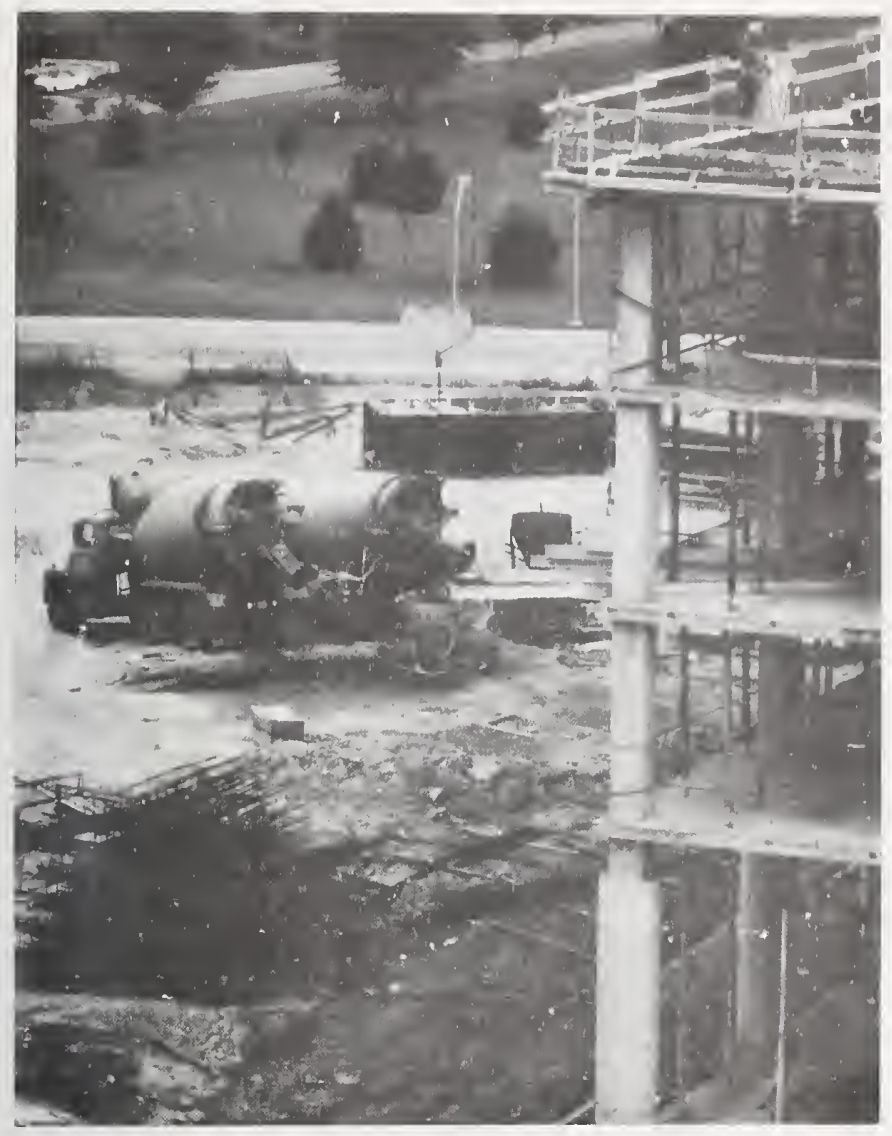

Figure 2.25: Loading of the concrete bucket

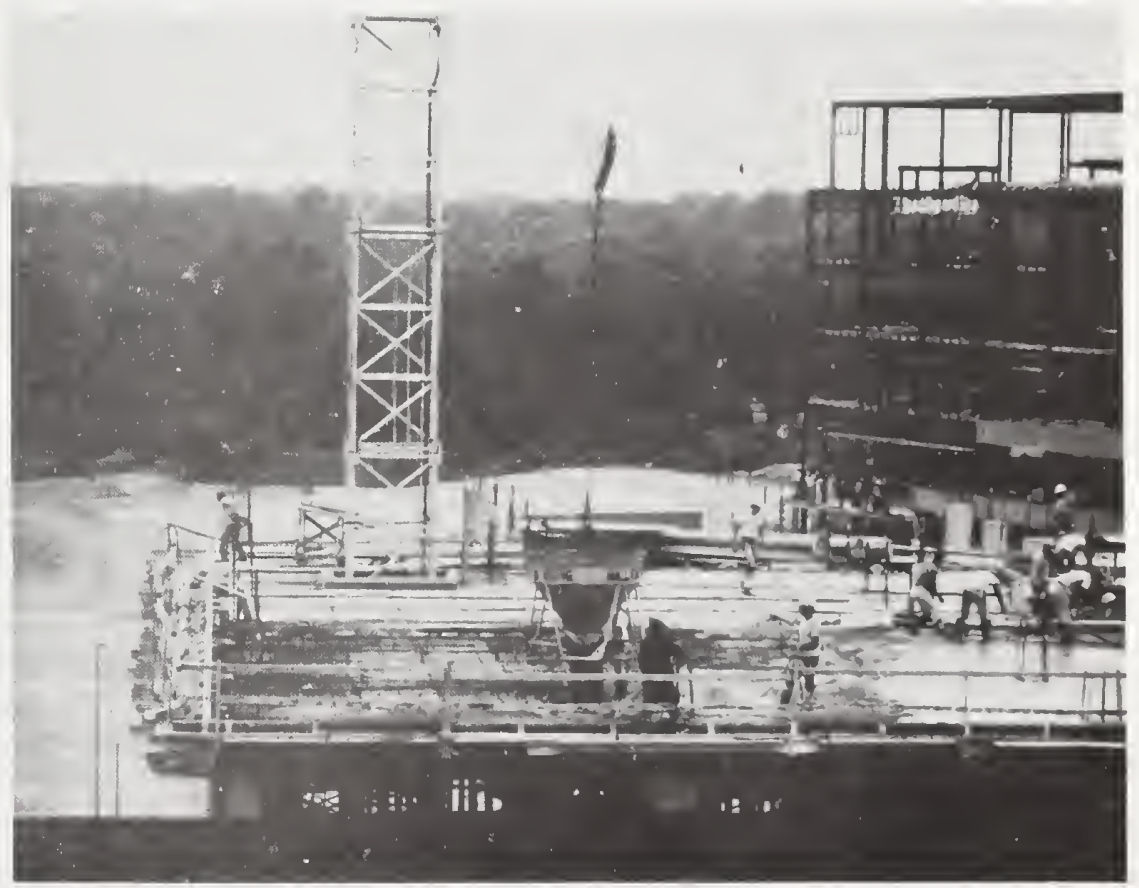

Figure 2.26: Casting of floor slab 


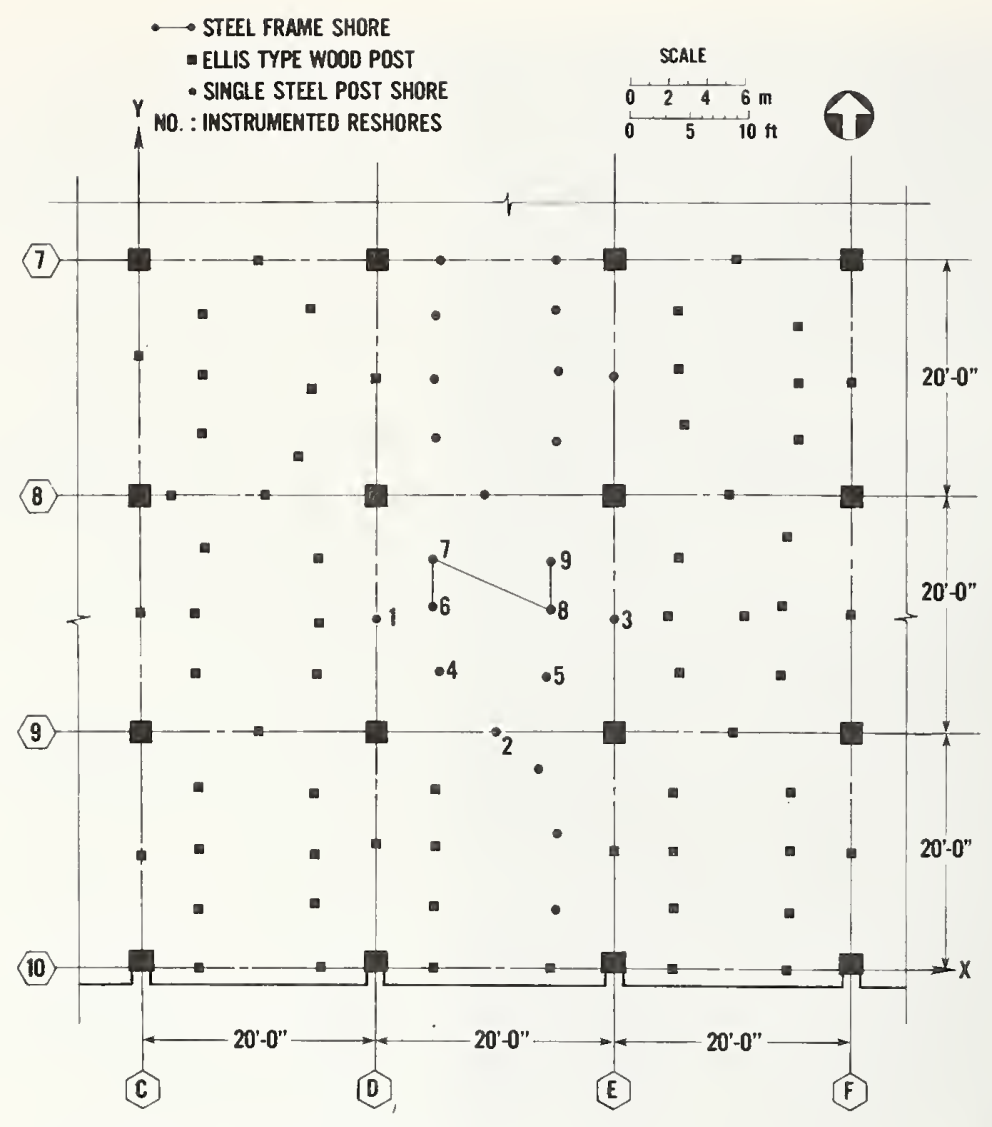

Coordinates of third story reshores

\begin{tabular}{|c|c|}
\hline Row & $(x, y)$ in $f t .$, rows in order of increasing $y$ \\
\hline Line $\mathrm{C}$ & $(0.00,9.75)(0.00,30.00)(2.67,40.00)(0.00,51.00)$ \\
\hline w. Line & $\begin{array}{l}(4.83,0.00)(4.83,5.00)(4.83,10.08)(4.83,15.33) / \\
(4.58,24.92)(4.58,29.92)(5.50,35.50) /(5.33,45.25) \\
(5.33,50.25)(5.33,55.33)\end{array}$ \\
\hline Midspan & $(9.92,20.00)(10.58,40.00)(10.00,60.00)$ \\
\hline E. Line & $\begin{array}{l}(15.17,0.00)(14.75,5.33)(14.75,9.58)(14.75,14.75) / \\
(15.00,24.92)(15.16,29.33)(15.16,34.58) /(14.42,43.25) \\
(14.58,50.08)(14.58,55.83)\end{array}$ \\
\hline Line $D$ & $(20.00,10.50)(20.00,29.50)(20.00,50.00)$ \\
\hline W. Line & $\begin{array}{lll}(24.75,0.00) & (24.83,5.25)(24.83,10.17)(24.83,14.08) / \\
(25.25,25.08) & (24.75,30.58)(24.75,34.58) /(25.00,45.00) \\
(25.00,50.00) & (25.00,55.42)\end{array}$ \\
\hline Midspan & $(30.08,20.00)(29.08,40.00)$ \\
\hline E. Line & $\begin{array}{l}(34.67,0.00)(35.08,4.83)(35.25,11.25)(33.58,16.75) / \\
(34.25,4.58)(34.67,30.33)(34.67,34.33) /(35.50,44.50) \\
(35.50,50.50)(35.17,55.67)\end{array}$ \\
\hline Line $\mathrm{E}$ & $(40.00,9.83)(40.00,29.75)(40.00,50.08)$ \\
\hline W. Line & $\begin{array}{l}(44.92,0.00)(45.00,5.08)(45.00,9.83)(45.00,14.83) / \\
(45.42,30.00)(44.58,34.83)(45.42,39.67) /(45.83,45.92) \\
(45.33,50.67)(45.33,55.58)\end{array}$ \\
\hline Midspan & $(50.00,20.00)(50.67,29.92)(49.67,40.00)(50.25,60.00)$ \\
\hline E. Line & $\begin{array}{l}(54.58,0.00)(54.75,4.67)(54.75,9.92)(54.75,14.83) / \\
(54.25,24.83)(55.17,29.83)(54.58,34.75) /(55.42,44.75) \\
(55.42,49.58)(55.42,54.33)\end{array}$ \\
\hline Line $F$ & $(60.00,9.92)(60.00,29.92)(60.00,49.67)$ \\
\hline
\end{tabular}

Figure 2.27: Third story reshores 


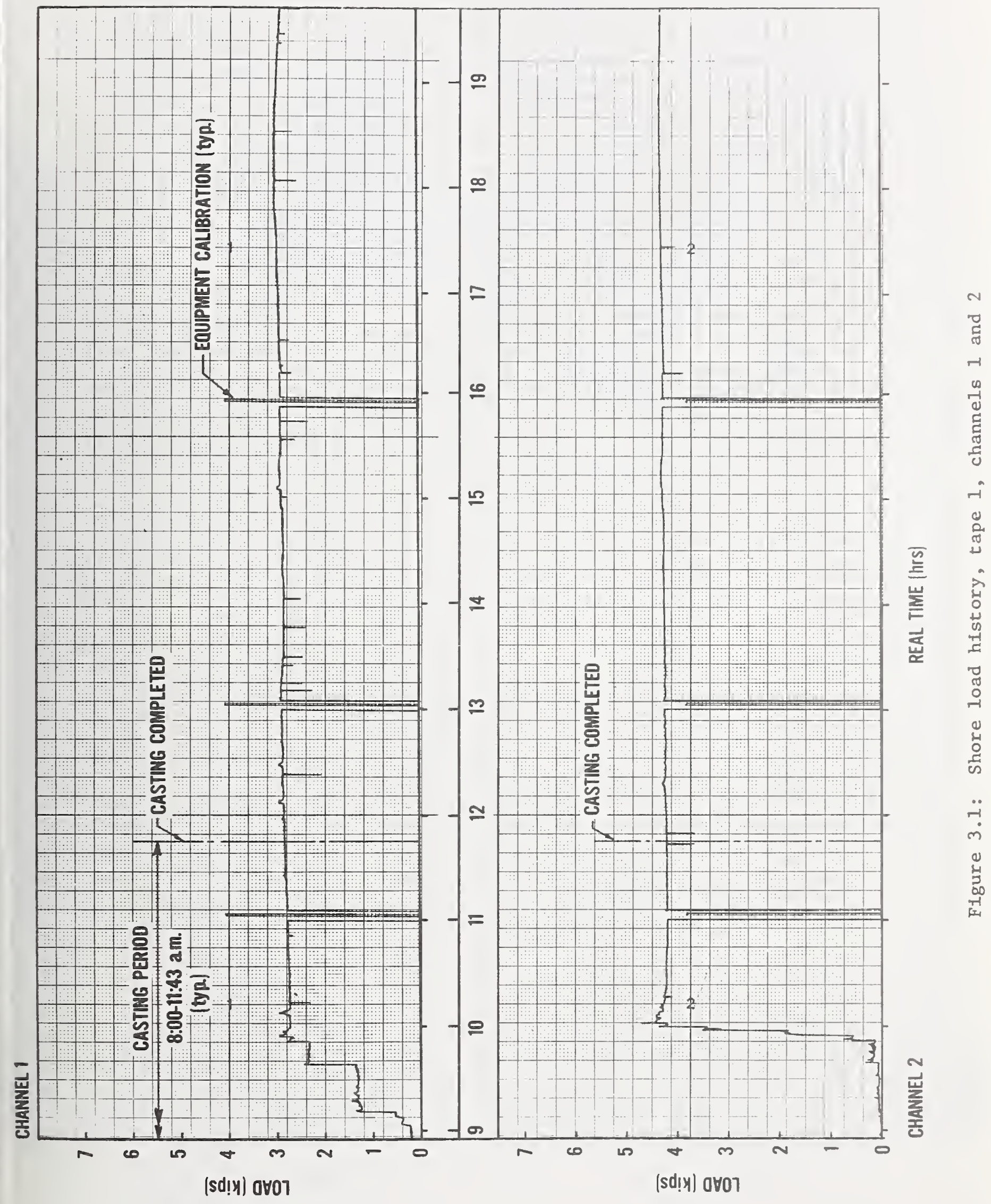




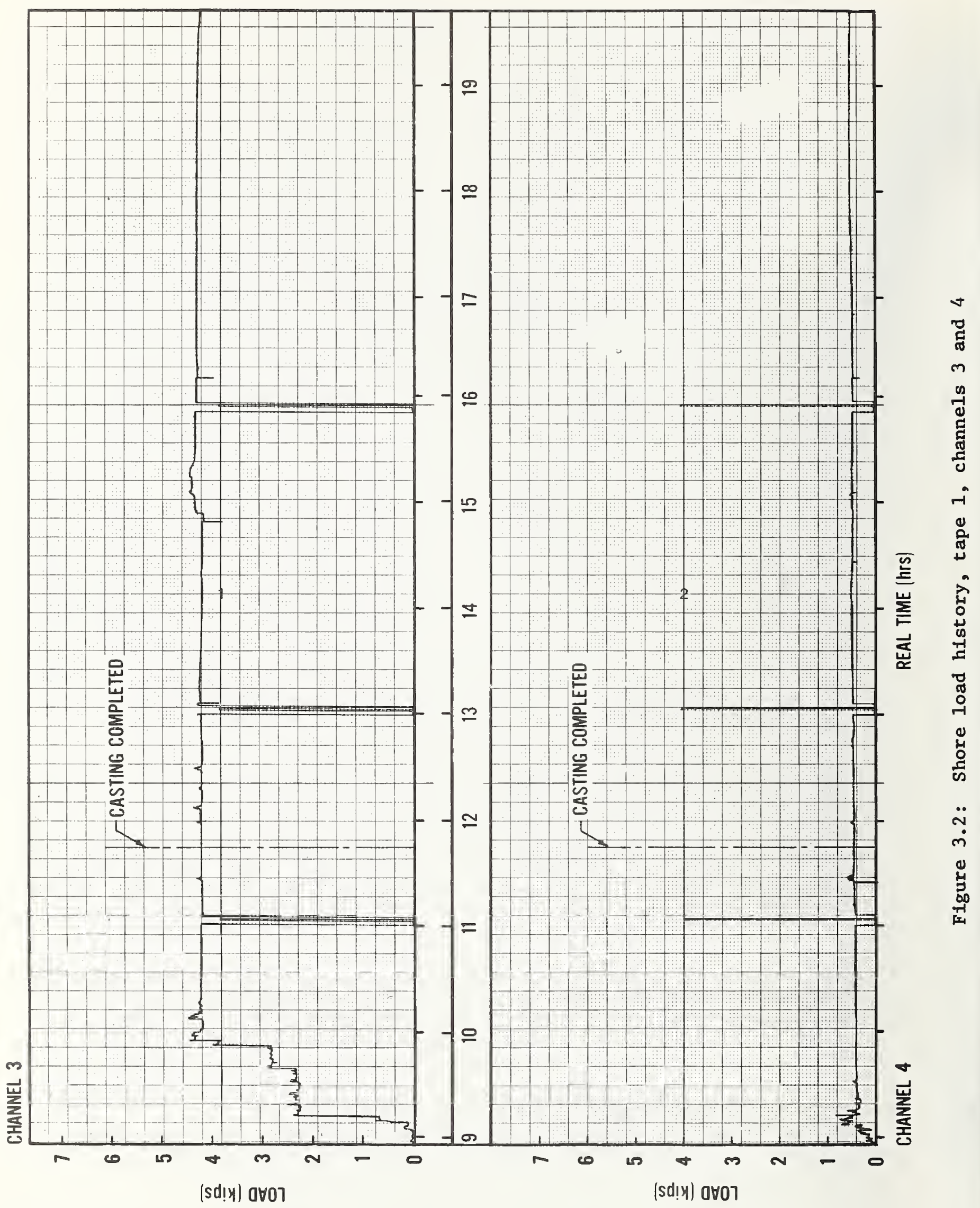




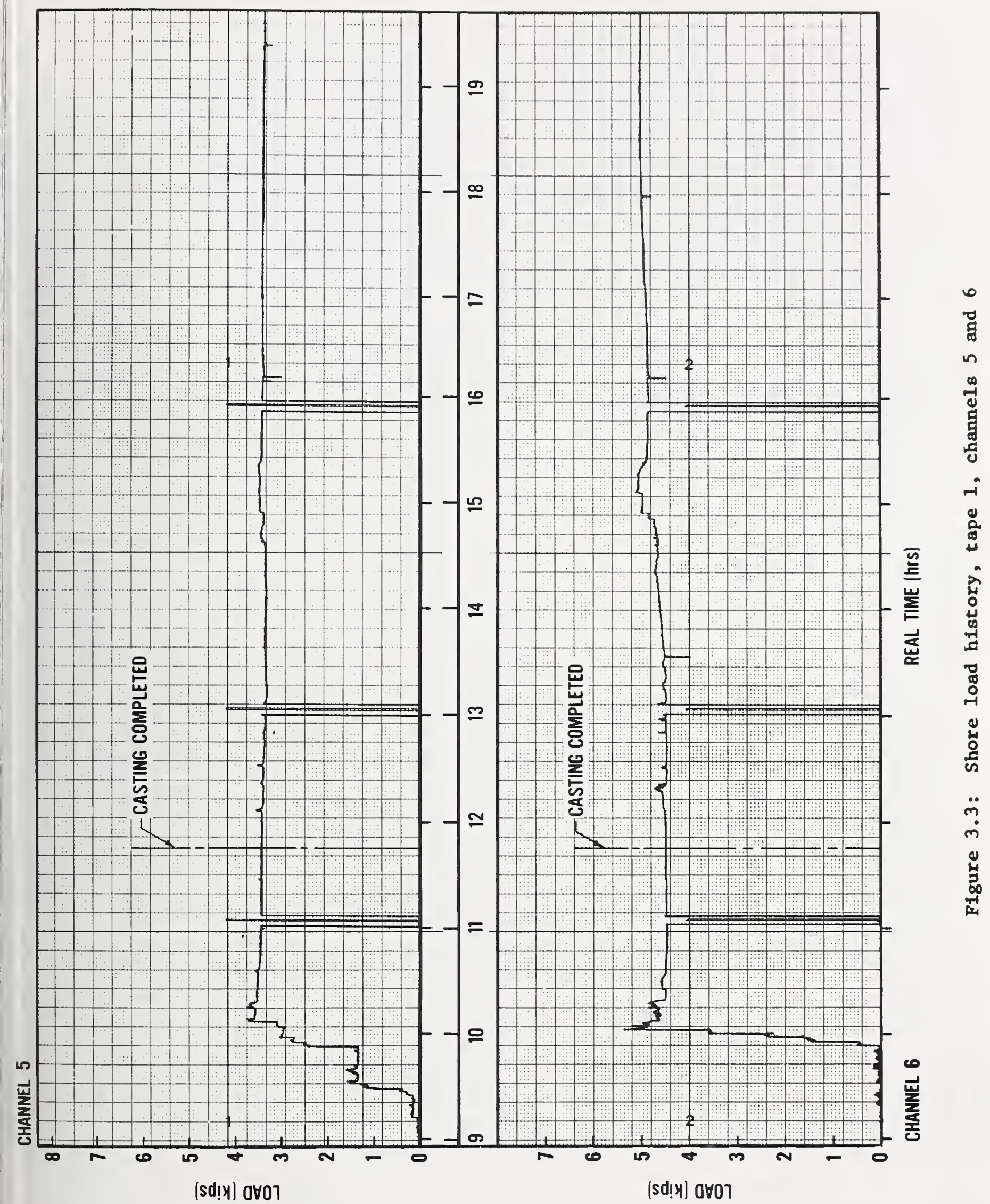




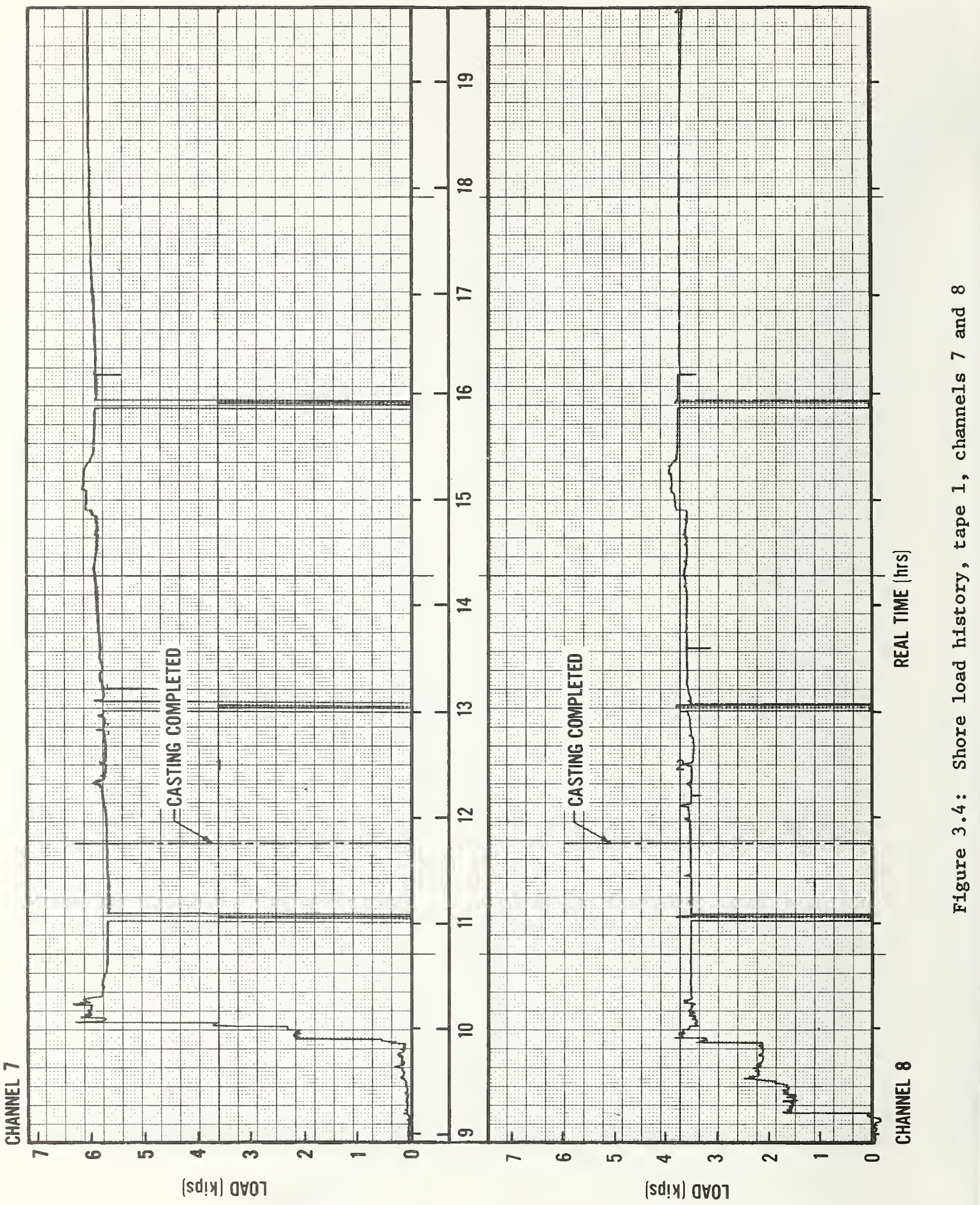




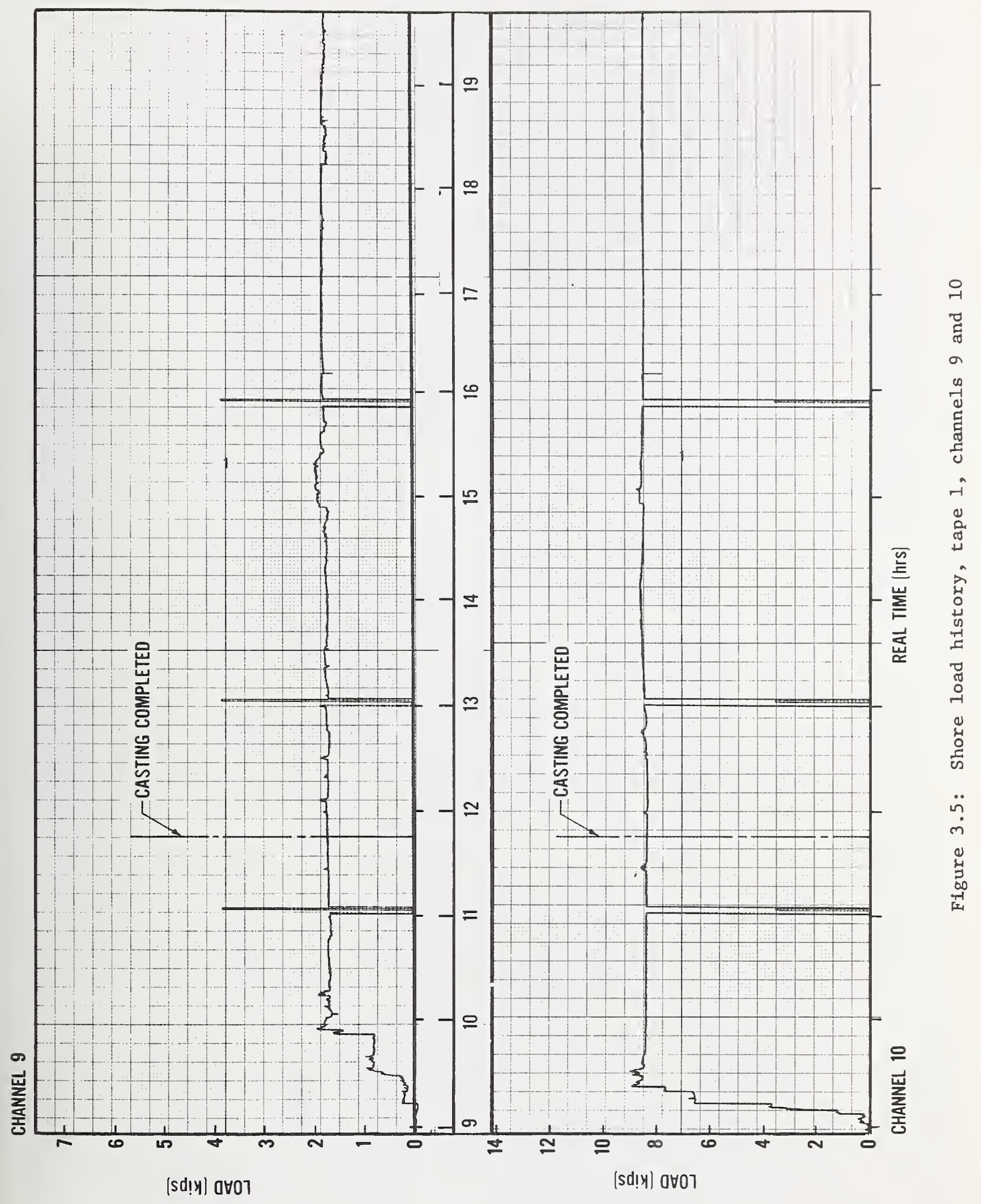




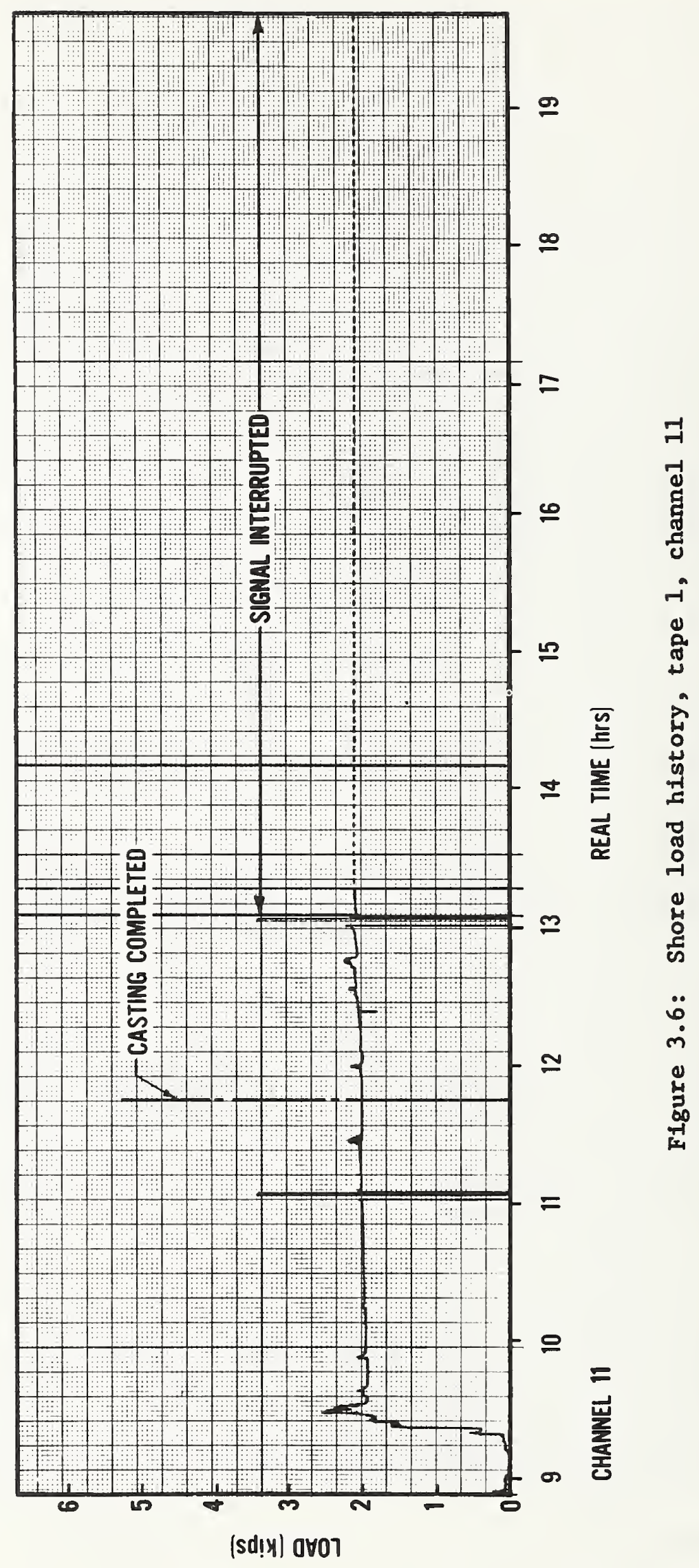




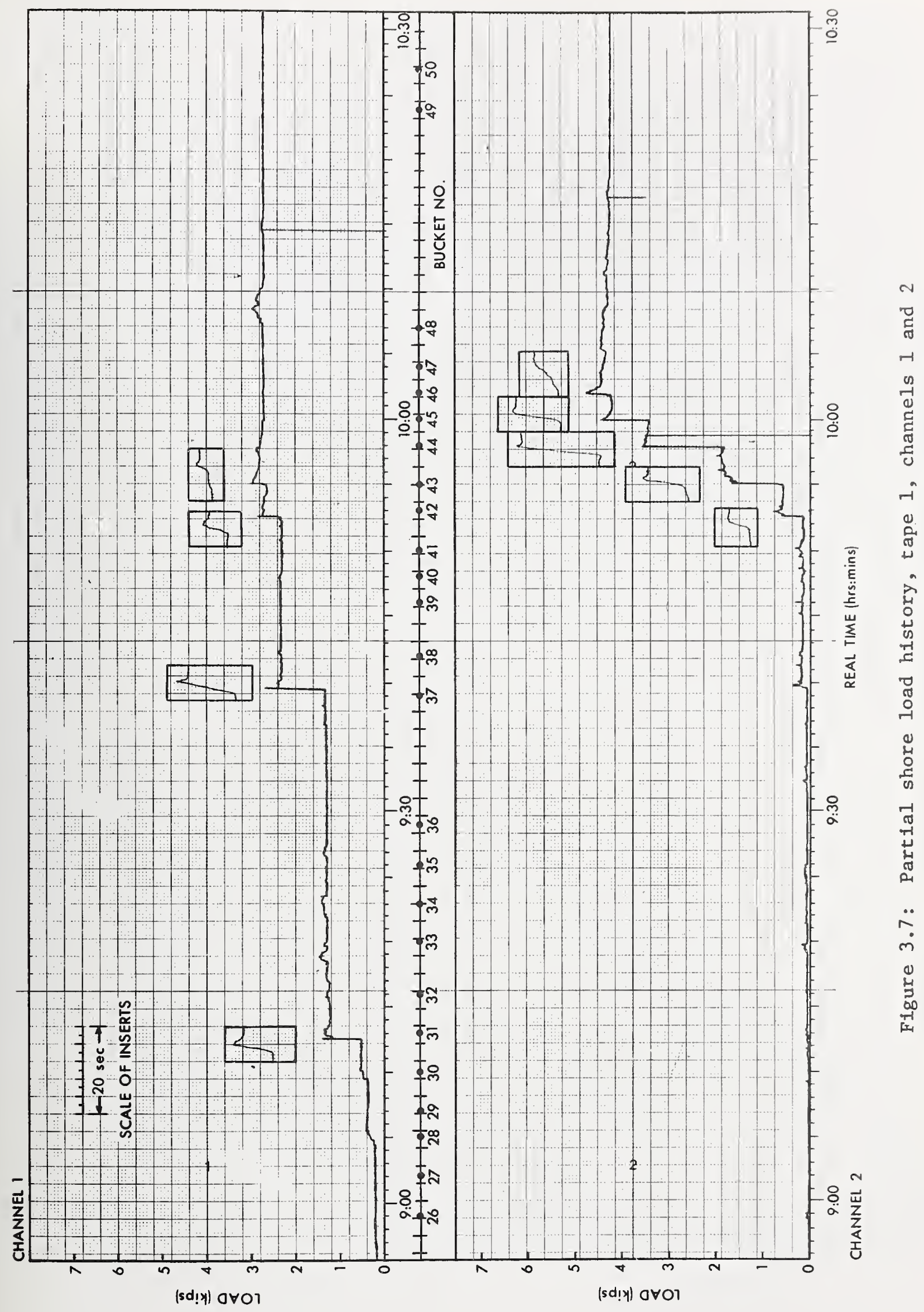




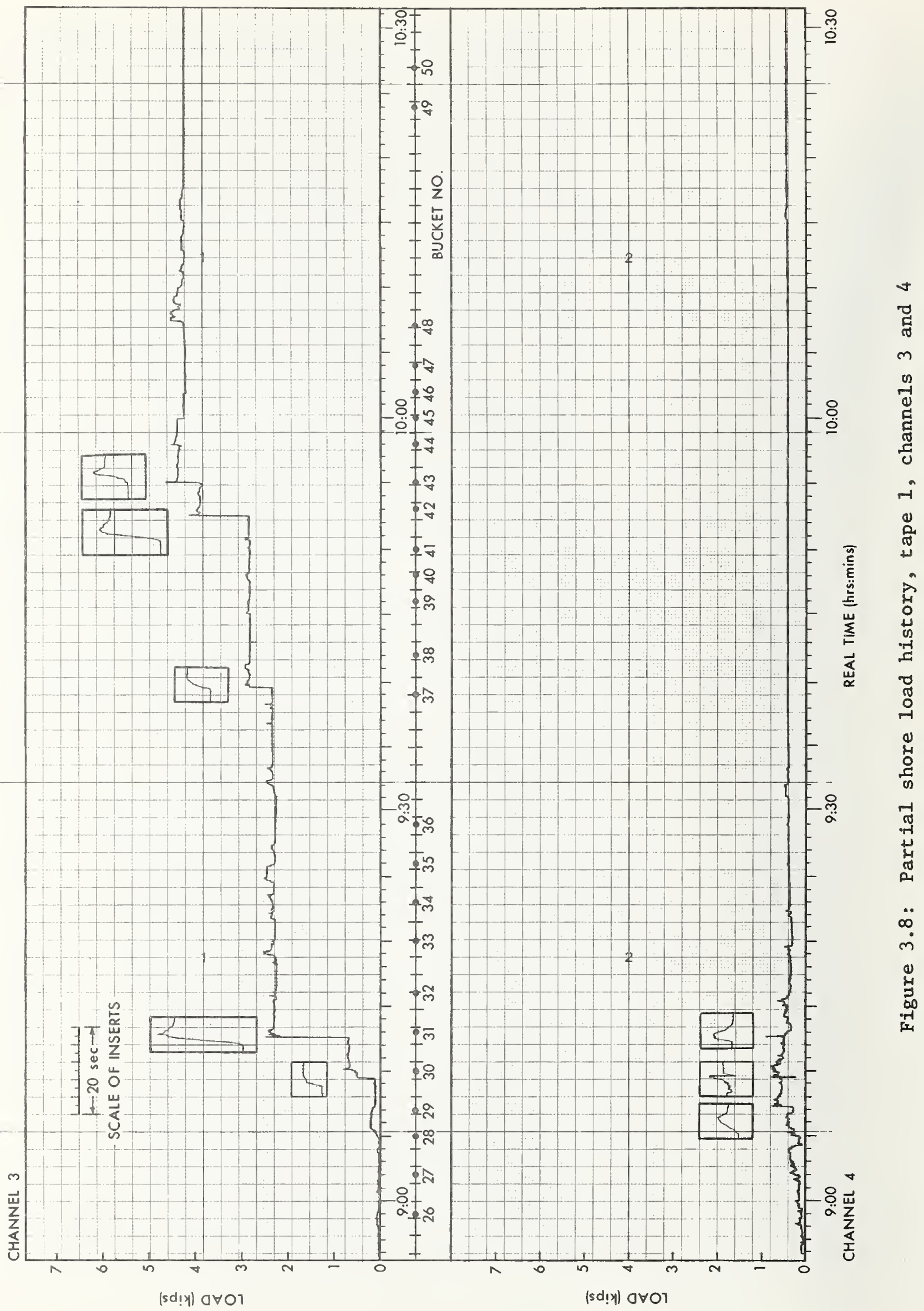




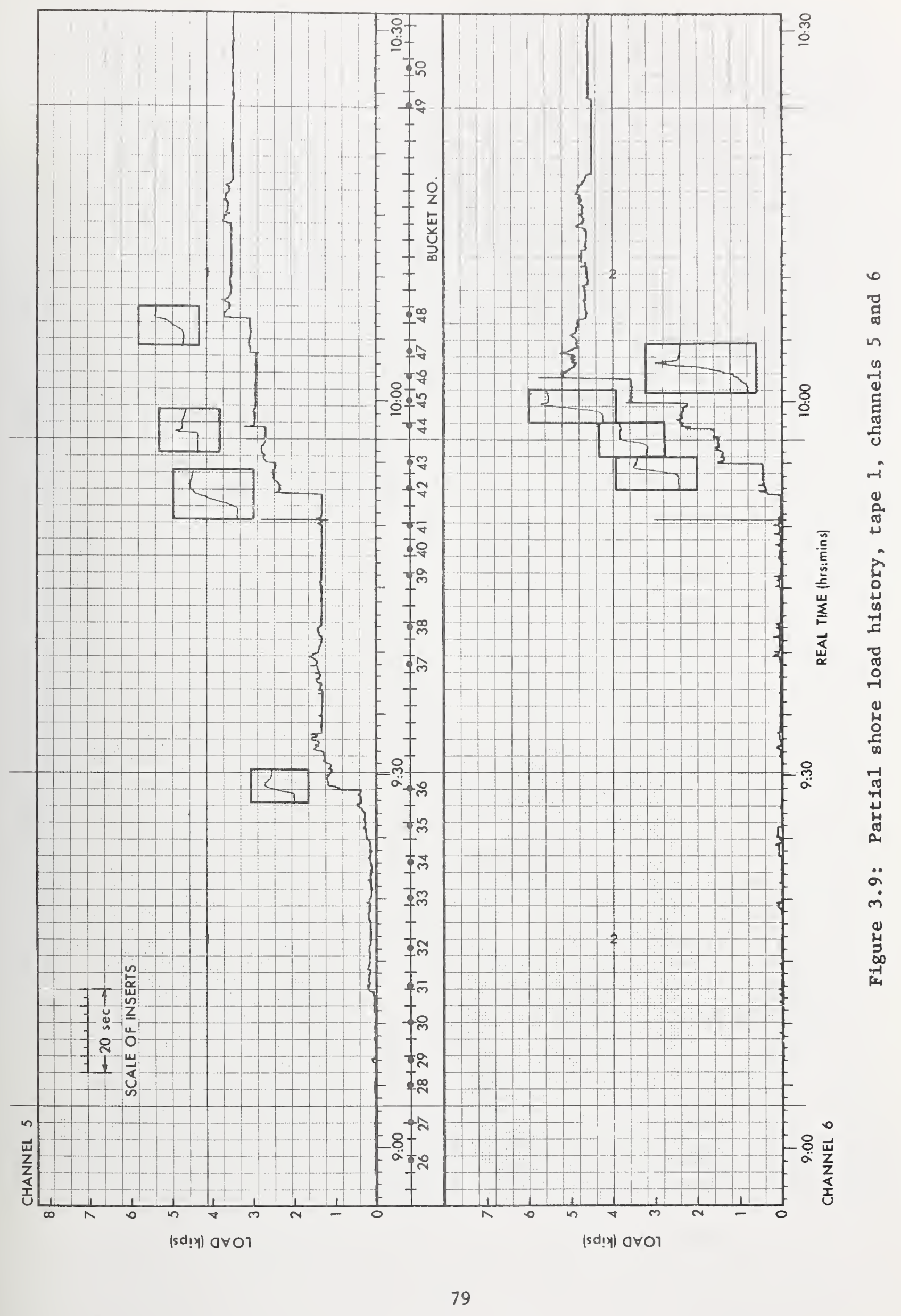




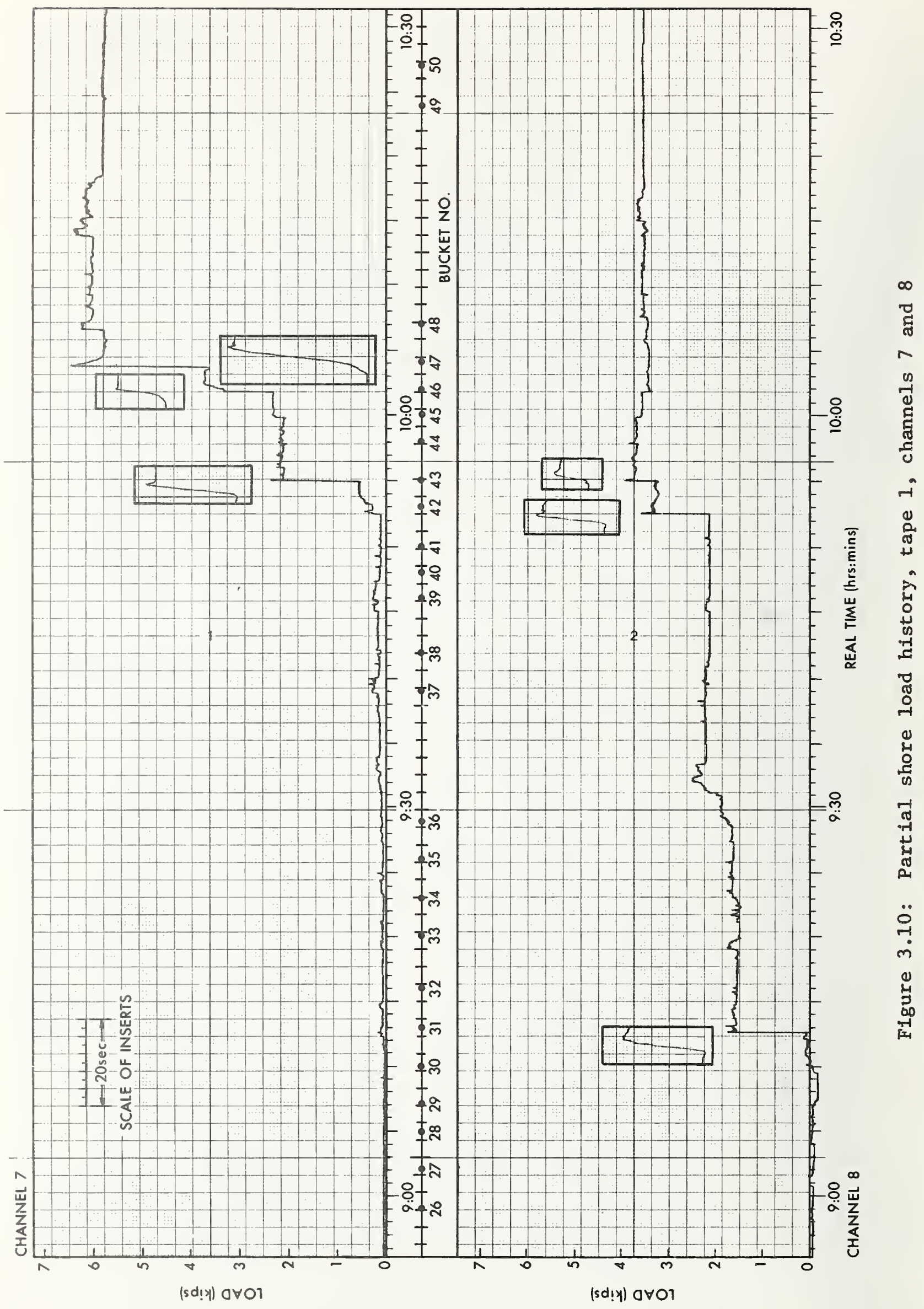




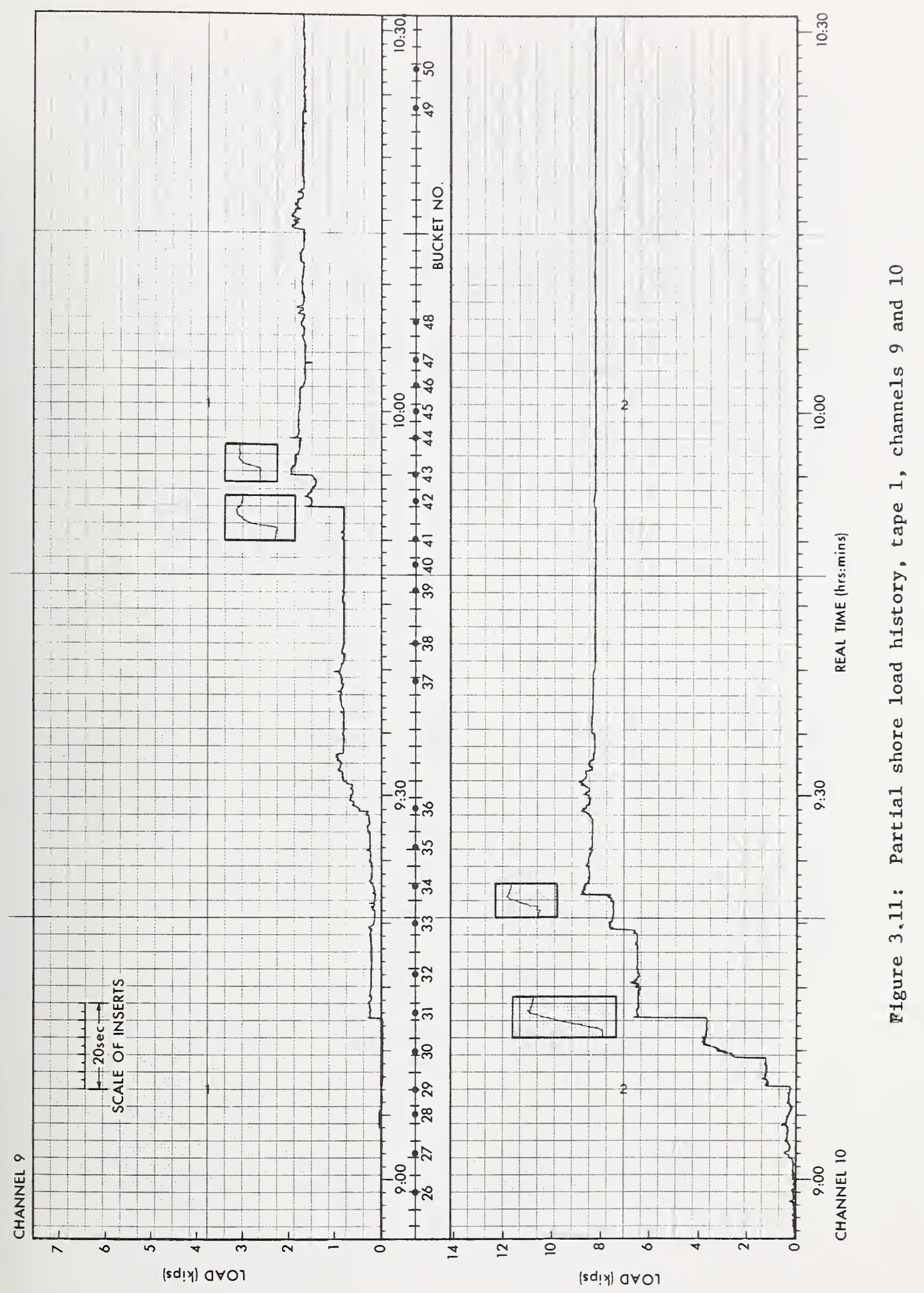




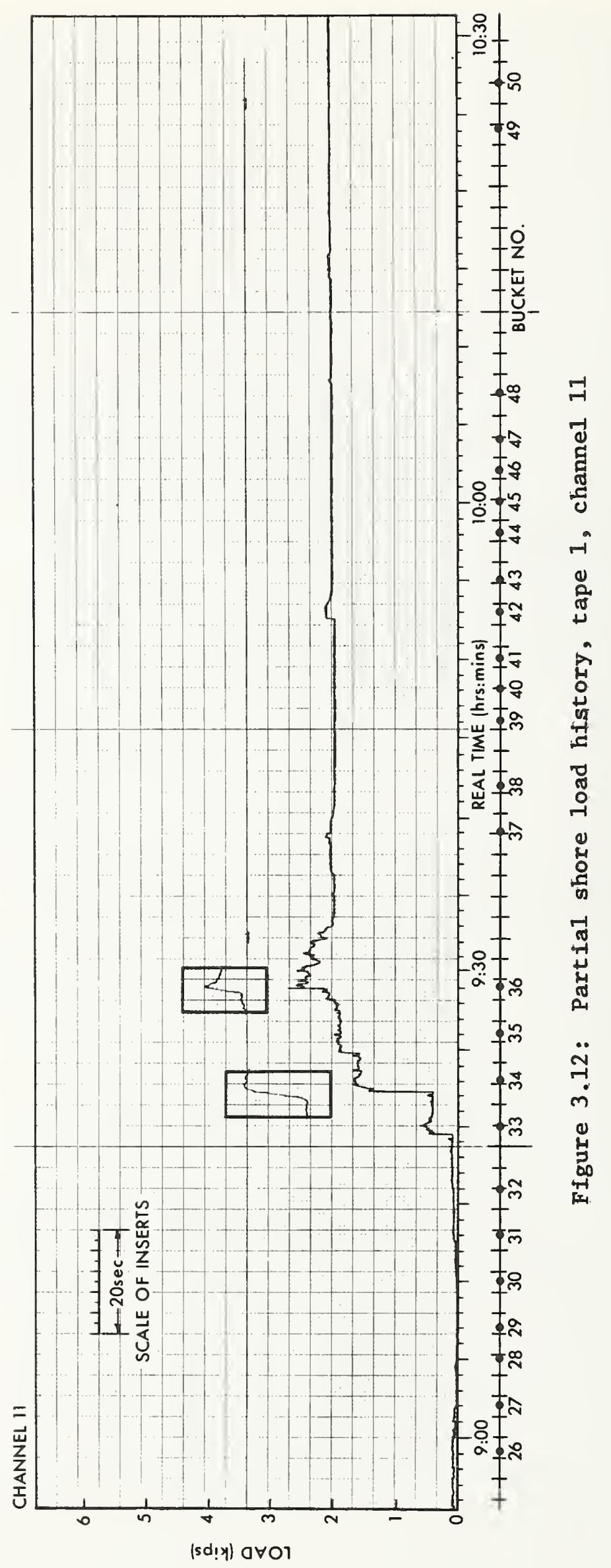




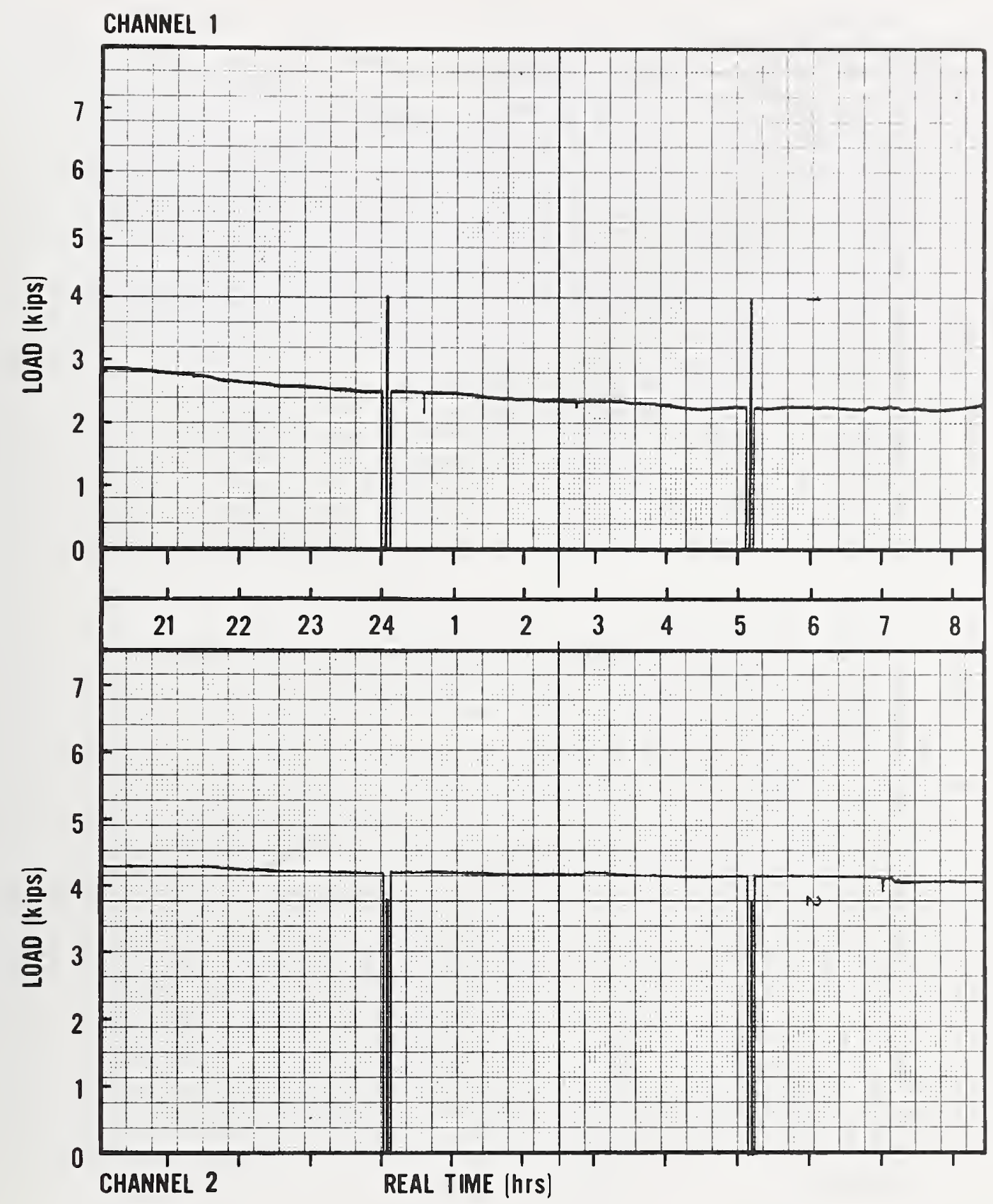

Figure 3.13: Shore load history, tape 2, chs. 1 and 2 


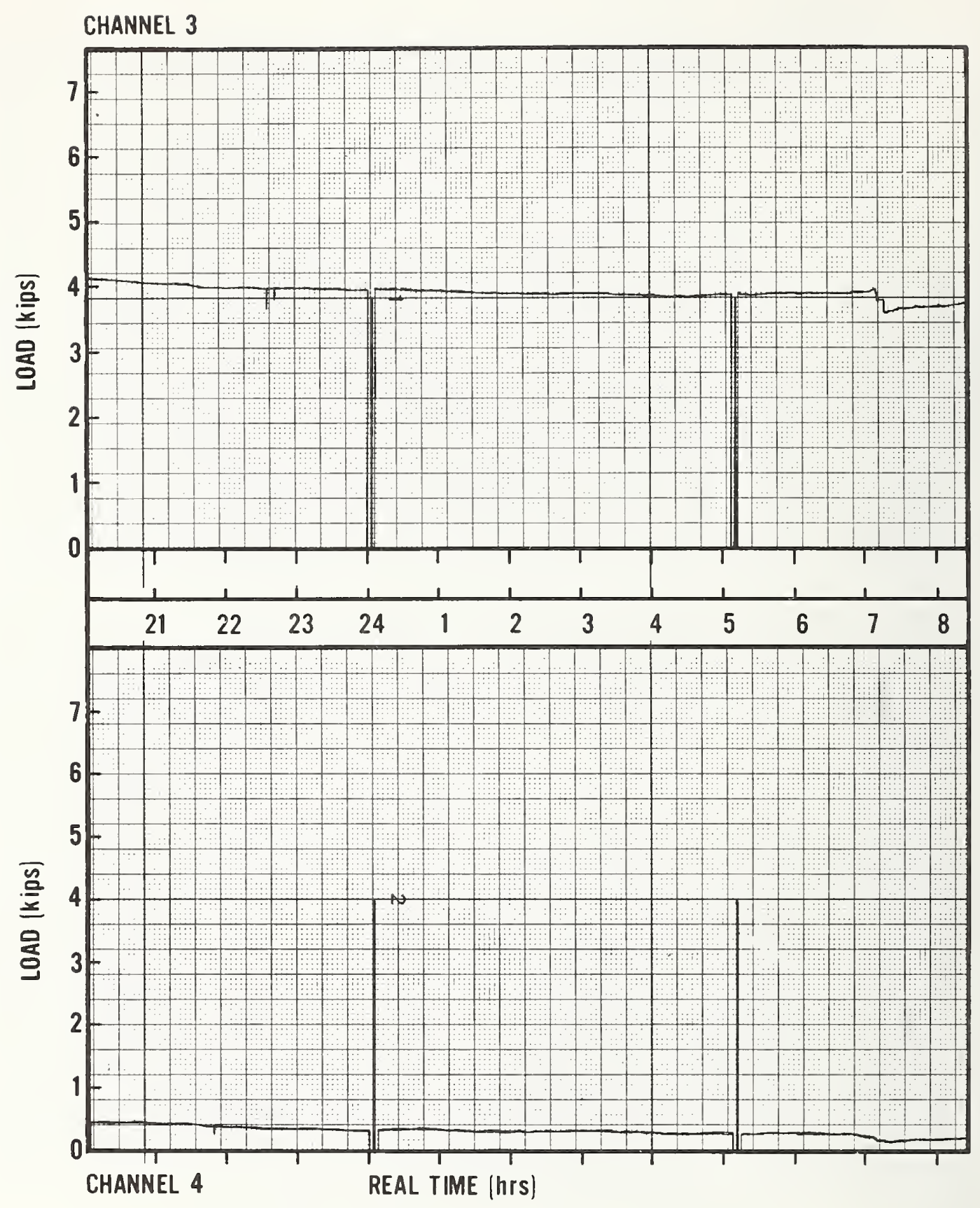

Figure 3.14: Shore load history, tape 2, chs. 3 and 4 
CHANNEL 5

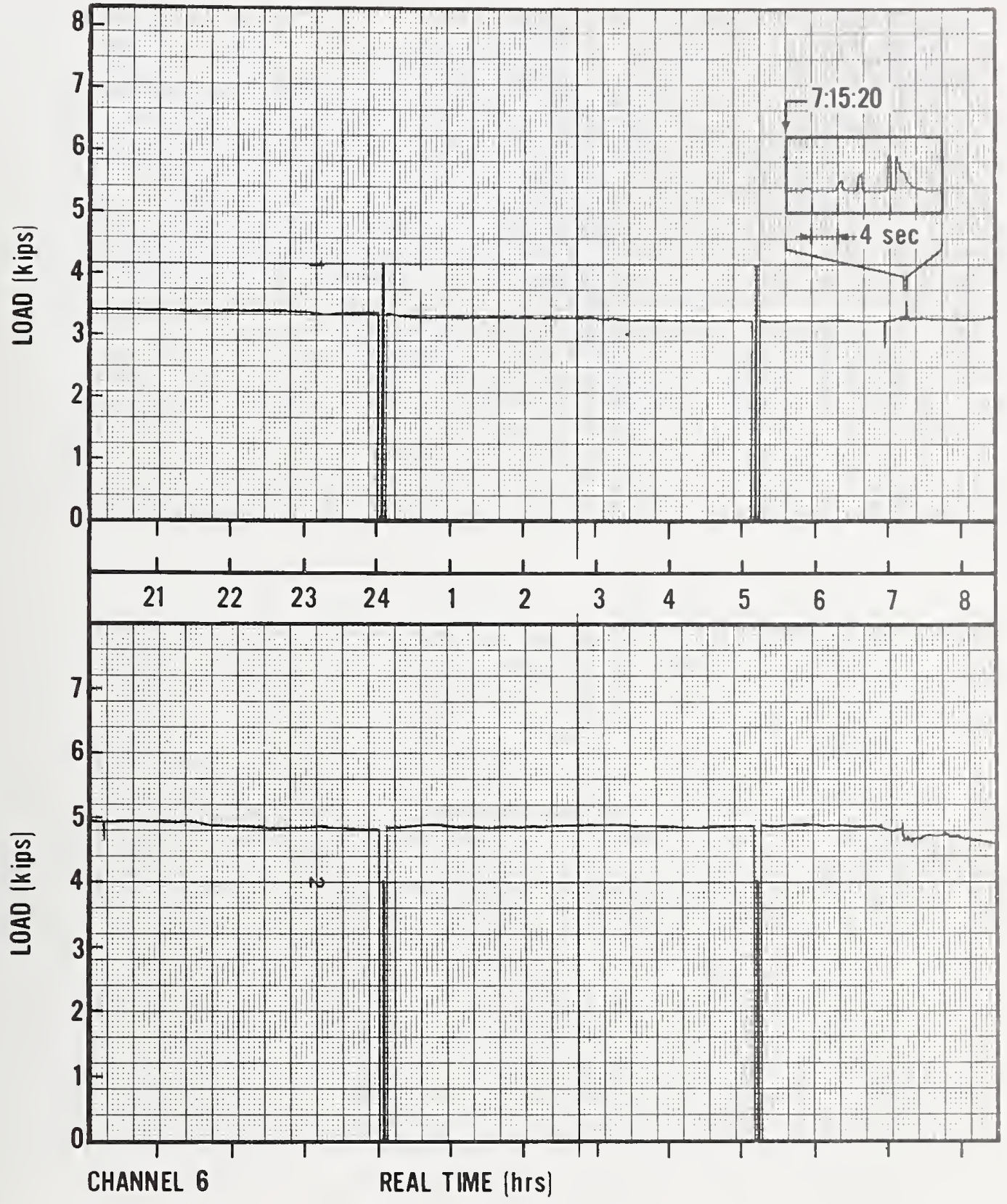

Figure 3.15: Shore load history, tape 2, chs. 5 and 6 


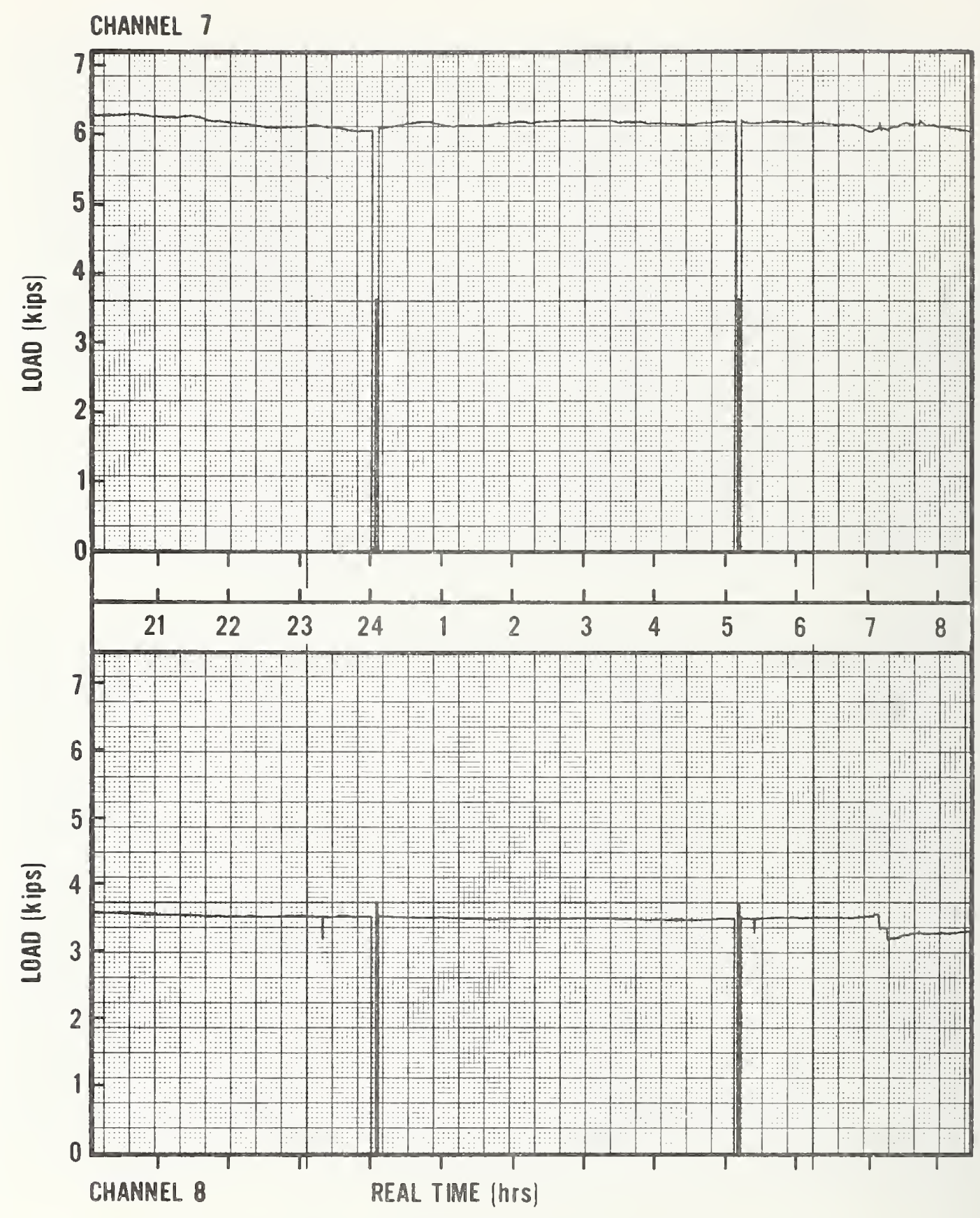

Pigure 3.16: Shore load history, tape 2, chs. 7 and 8 
CHANMEL 9

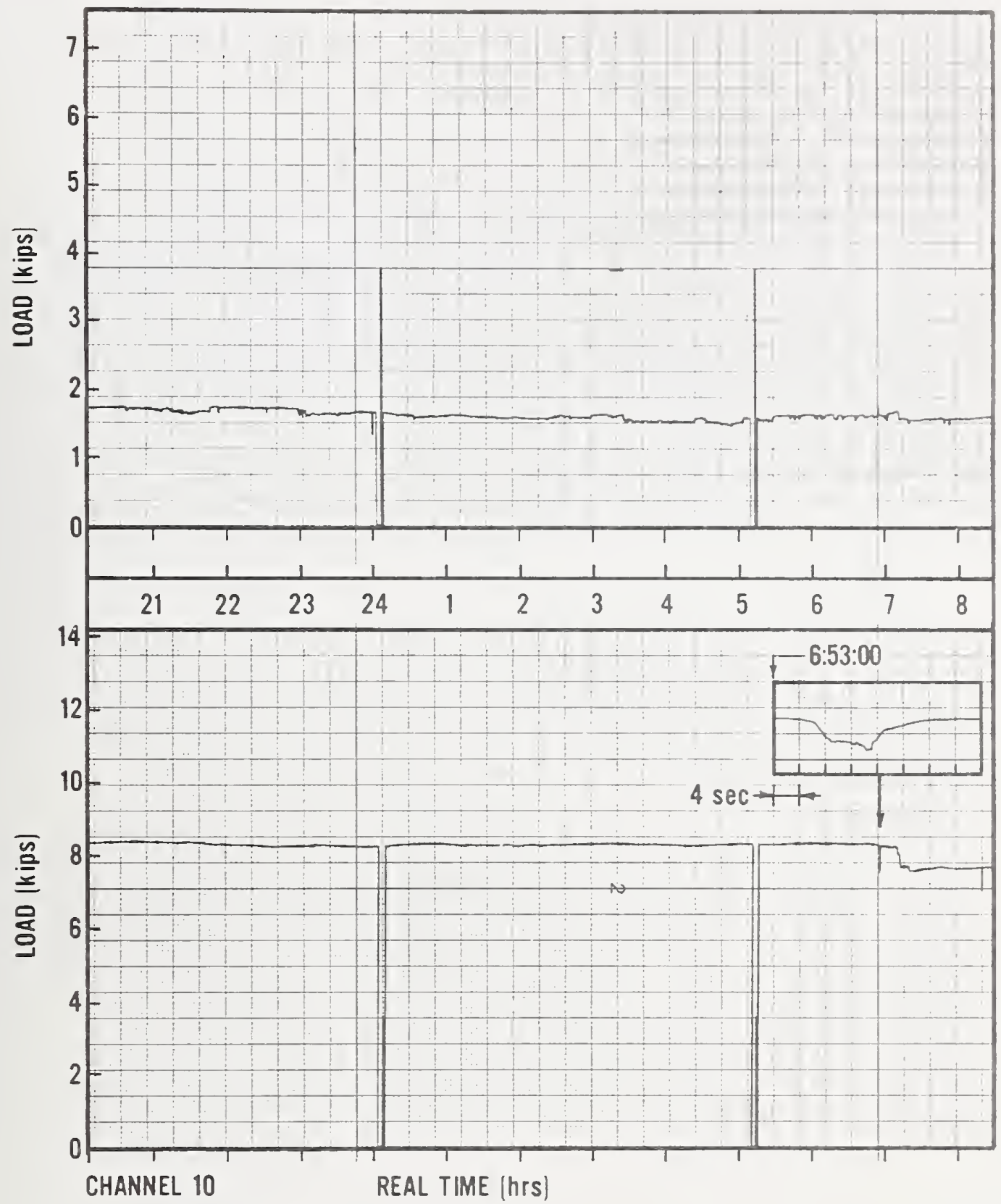

Figure 3.17: Shore load history, tape 2, chs. 9 and 10 


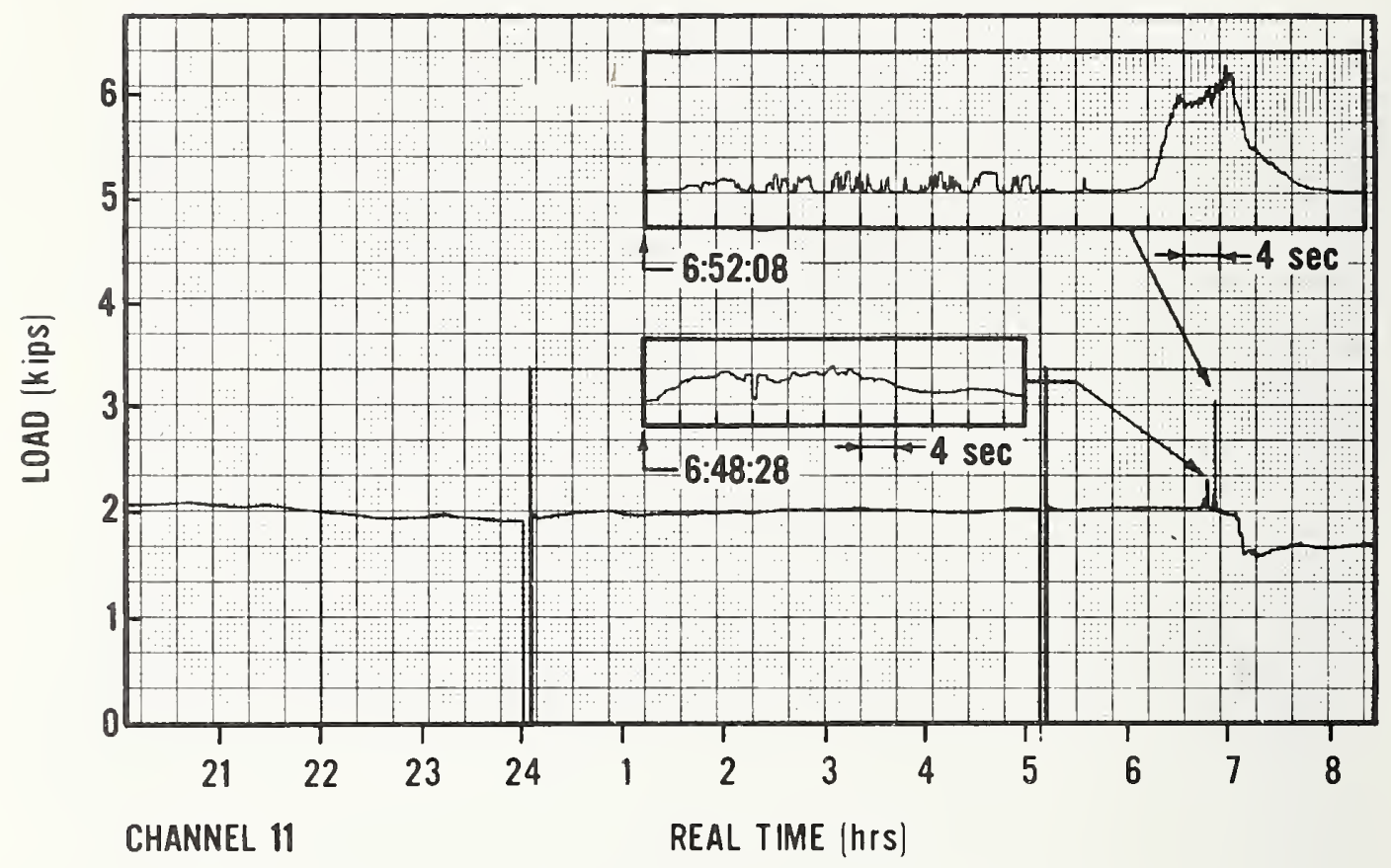

Figure 3.18: Shore load history, tape 2, ch. 11 
CHANNEL 1

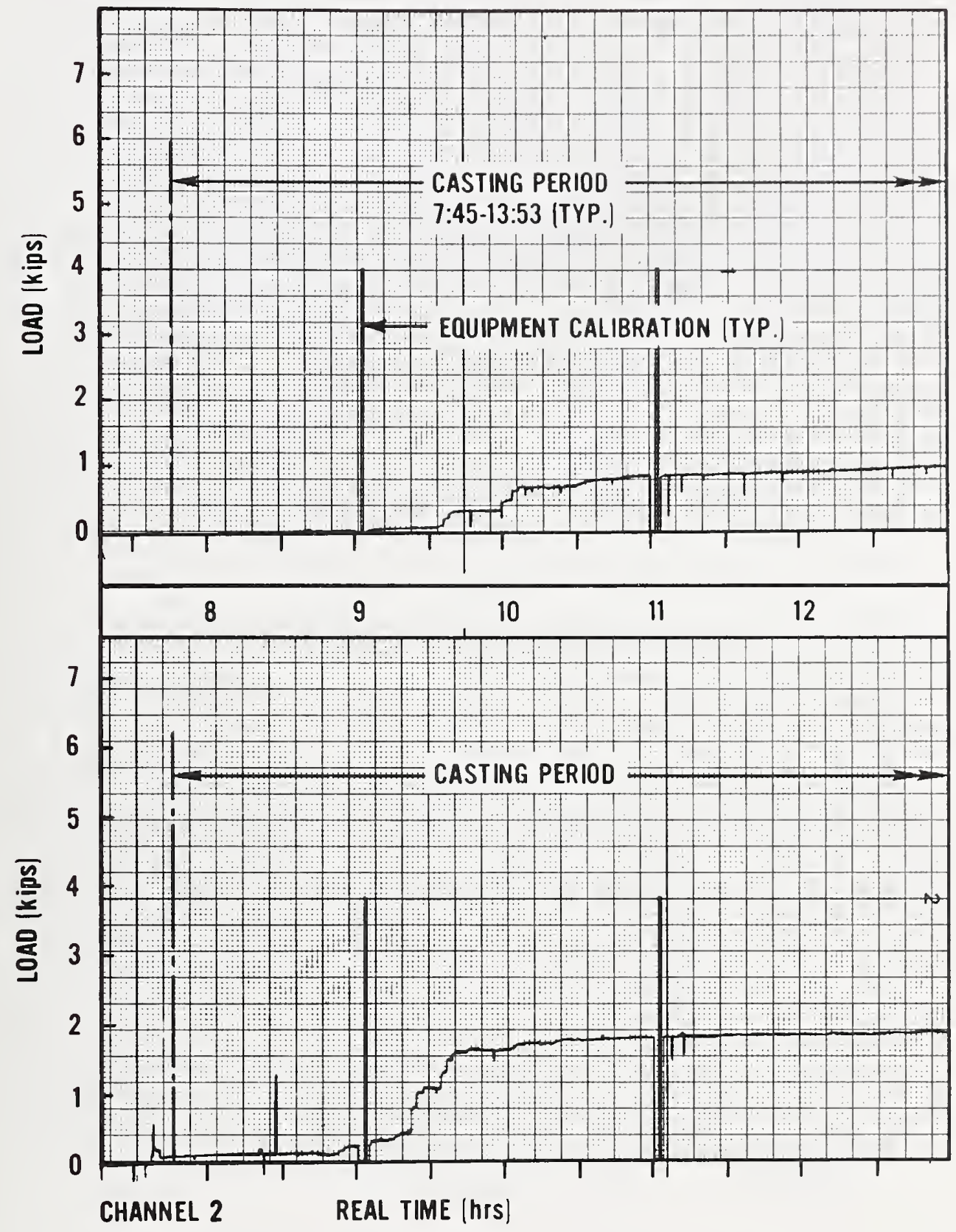

Figure 3.19: Reshore load history, chs. 1 and 2 


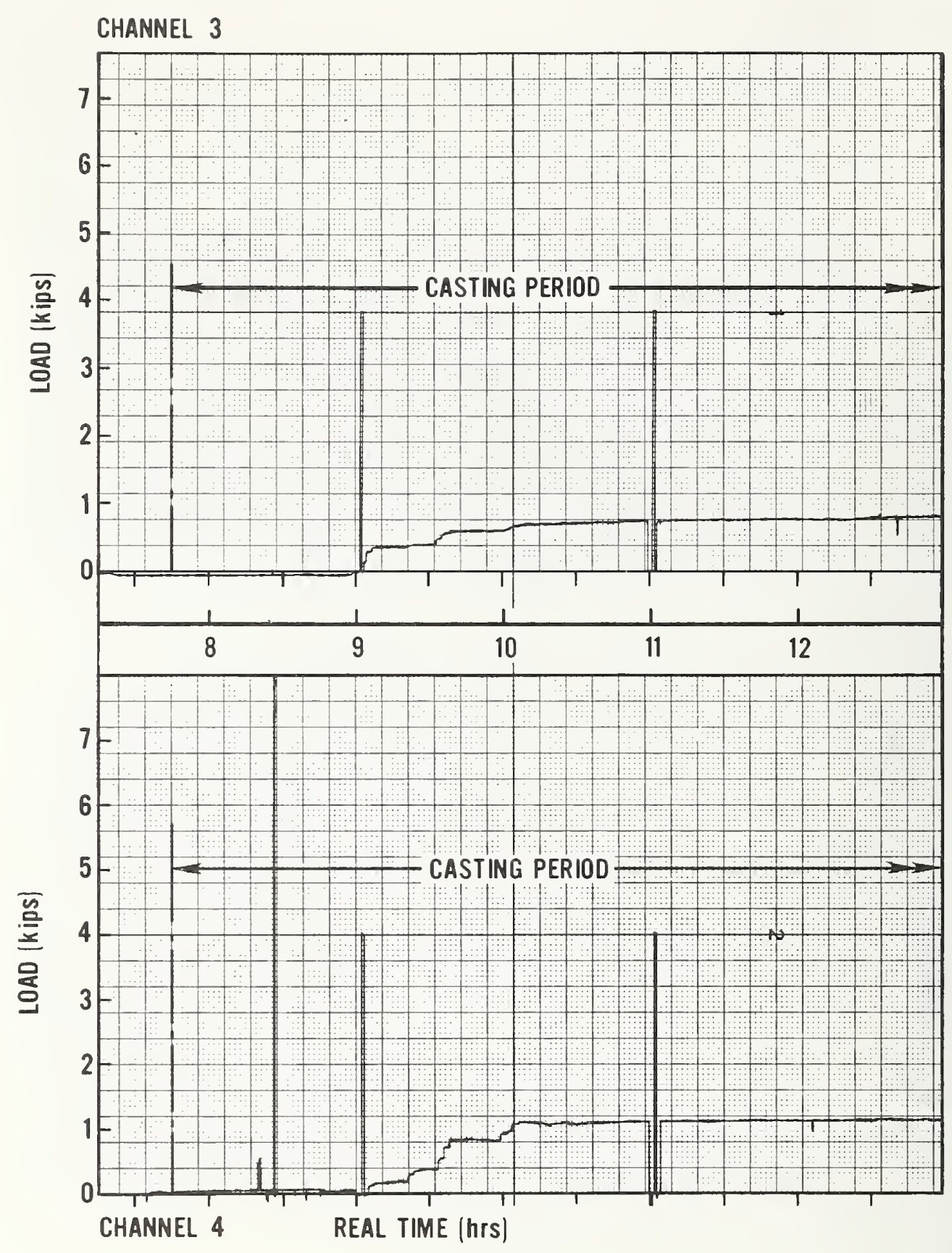

Figure 3.20: Reshore load history, chs. 3 and 4 


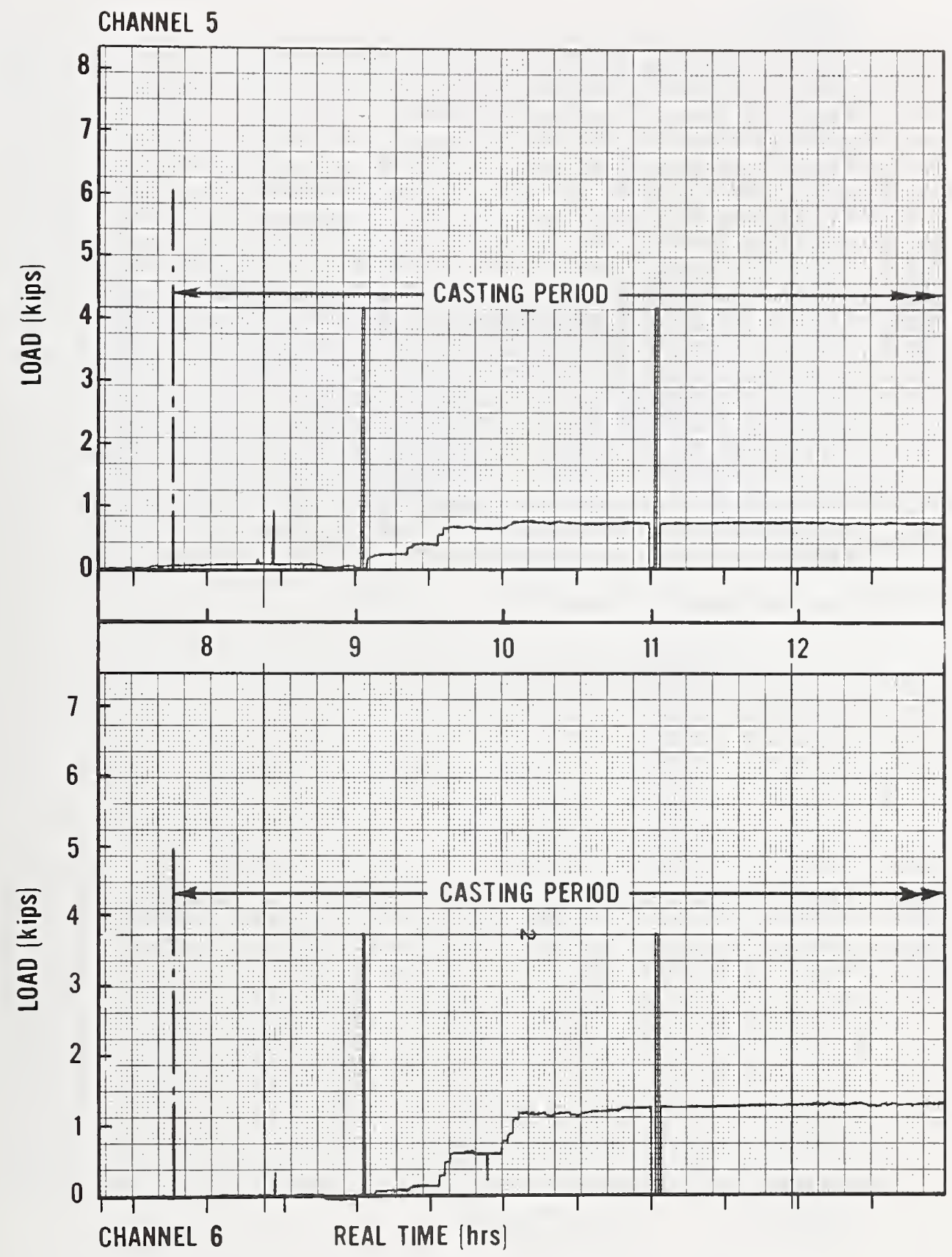

Figure 3.21: Reshore load history, chs. 5 and 6 


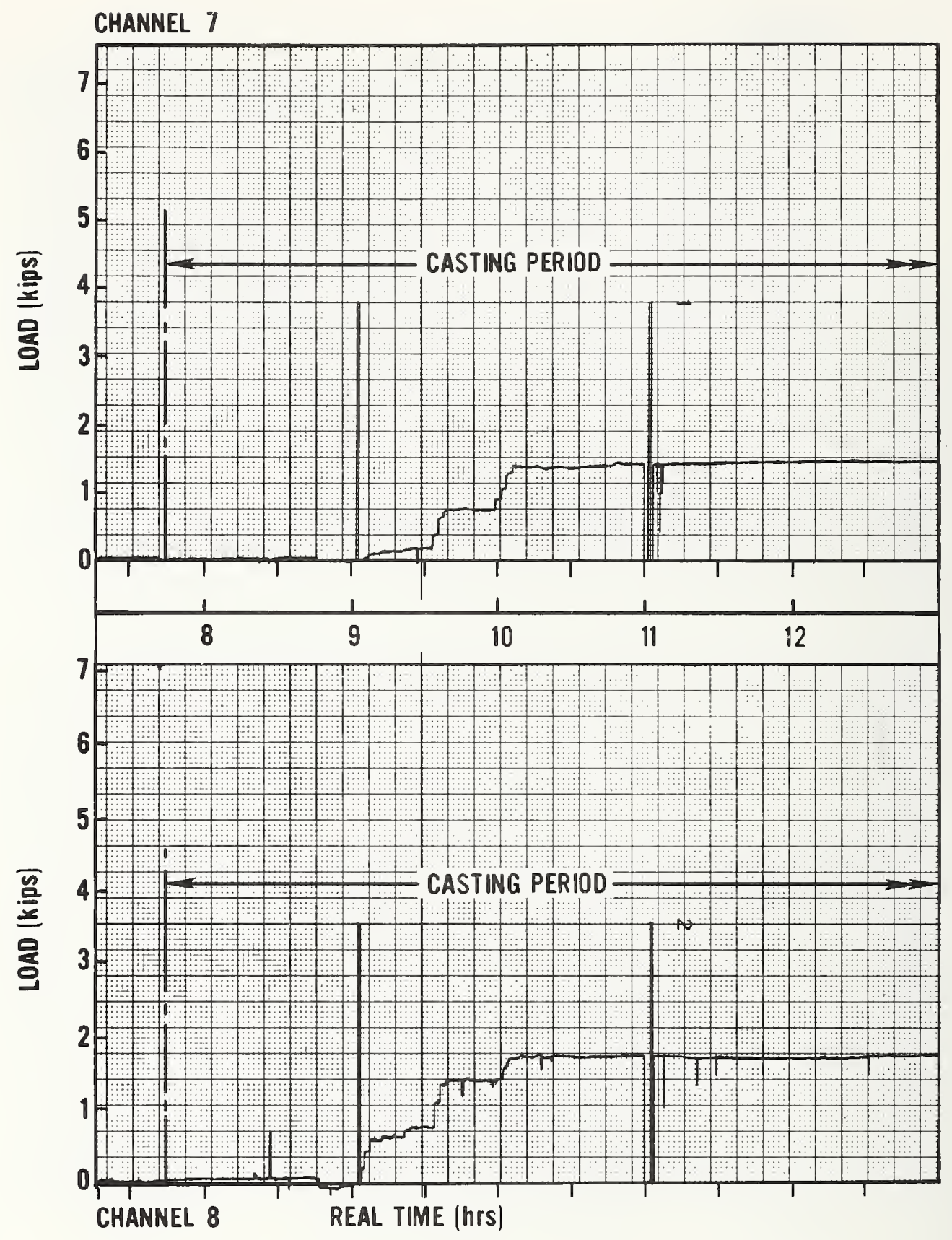

Figure 3.22: Reshore load history, chs. 7 and 8 


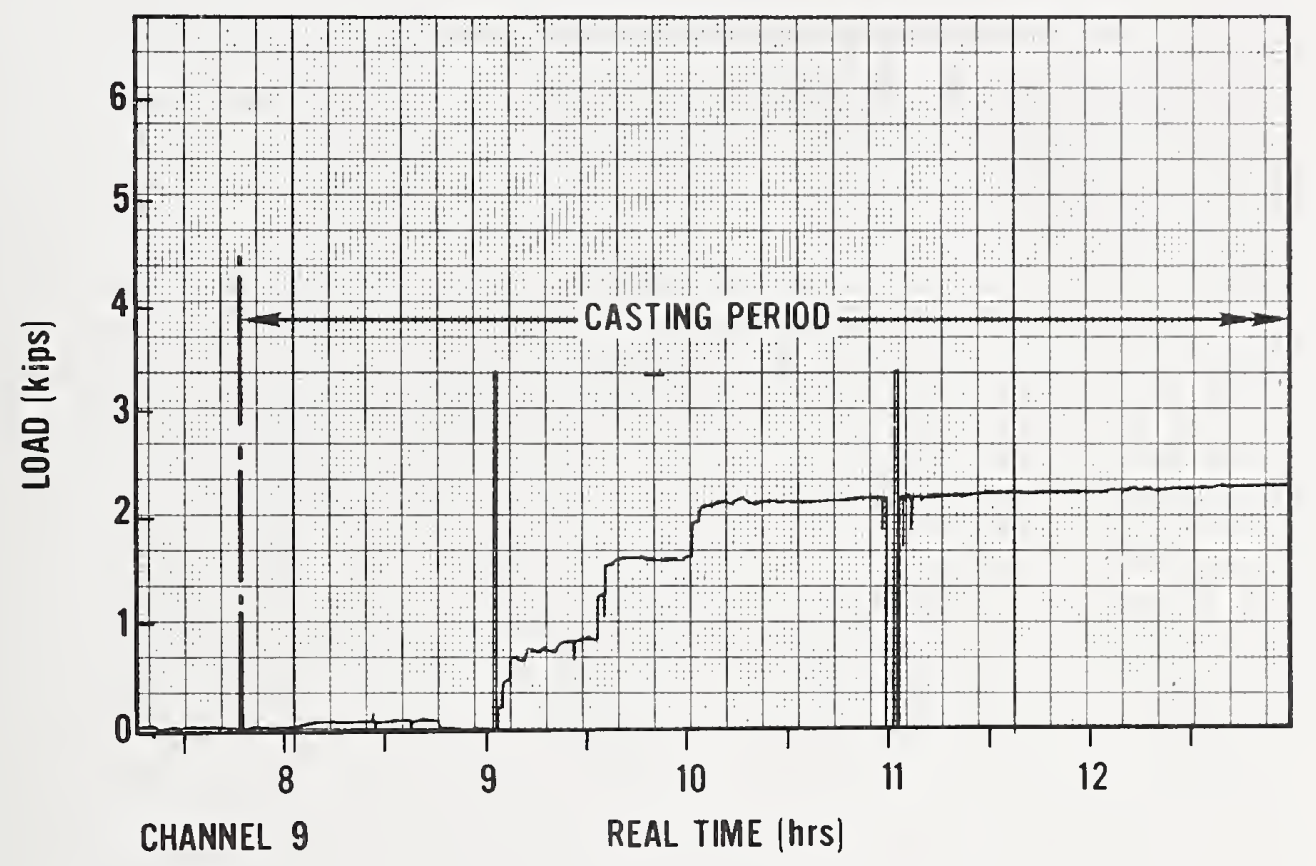

Figure 3.23: Reshore load history, ch. 9 


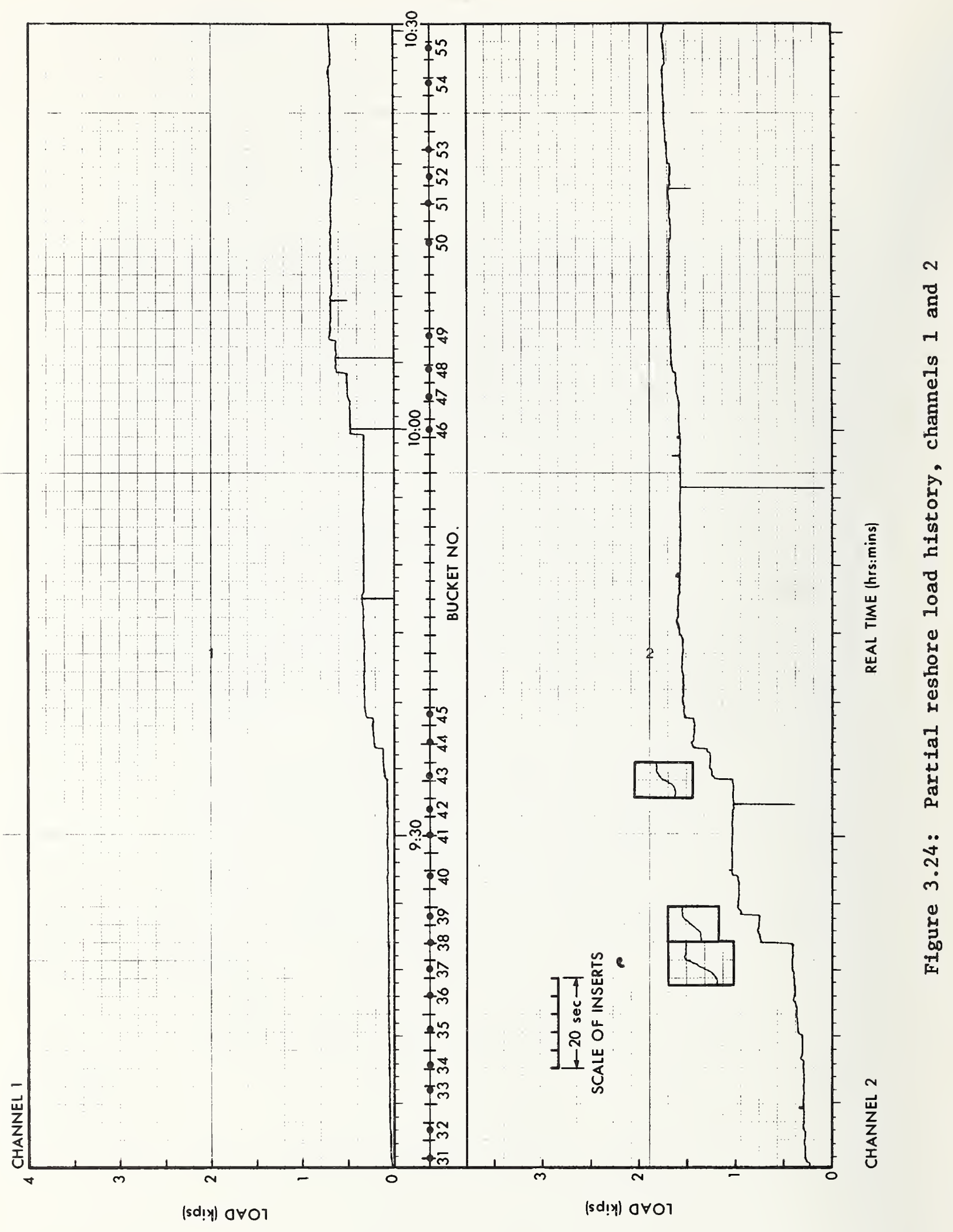




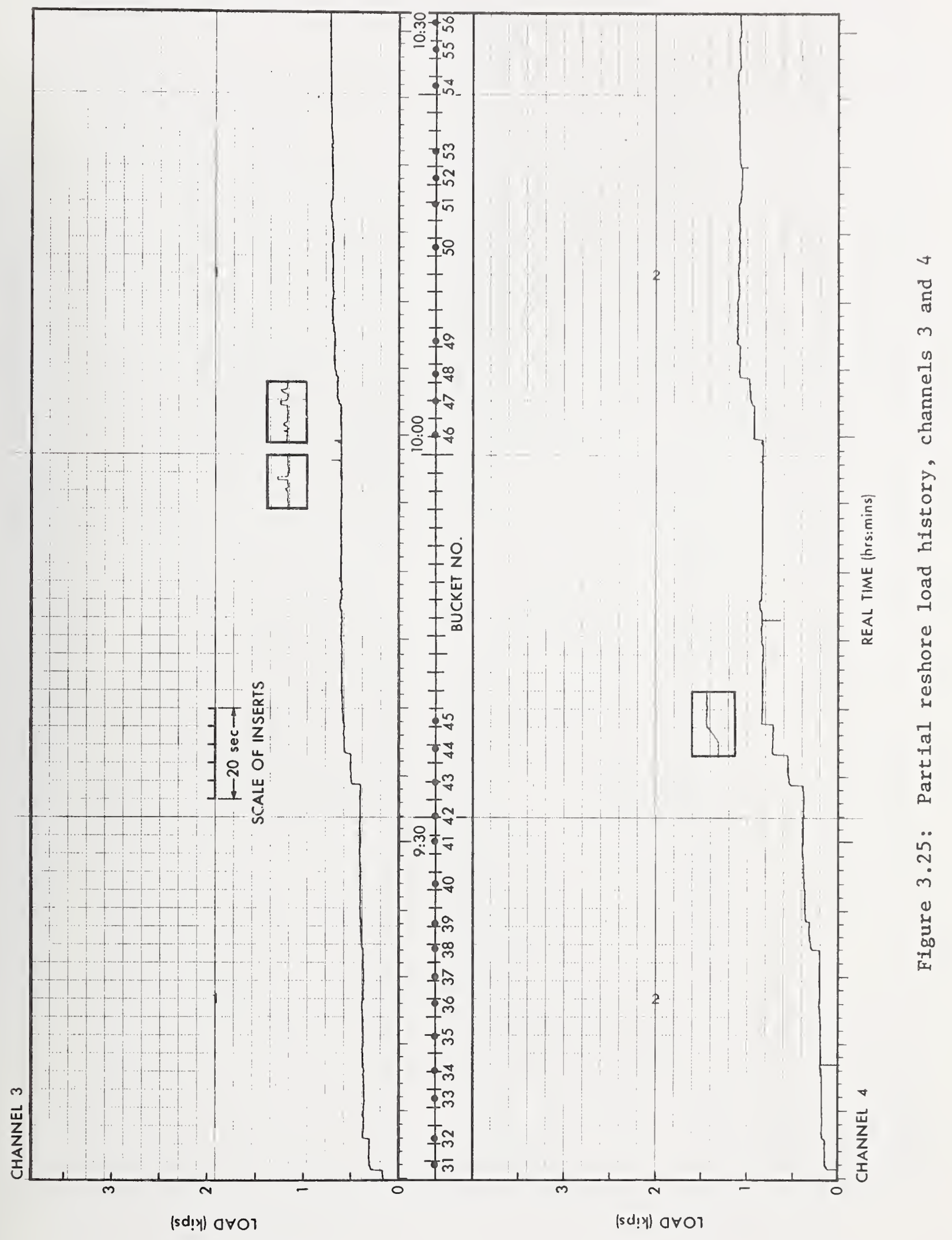




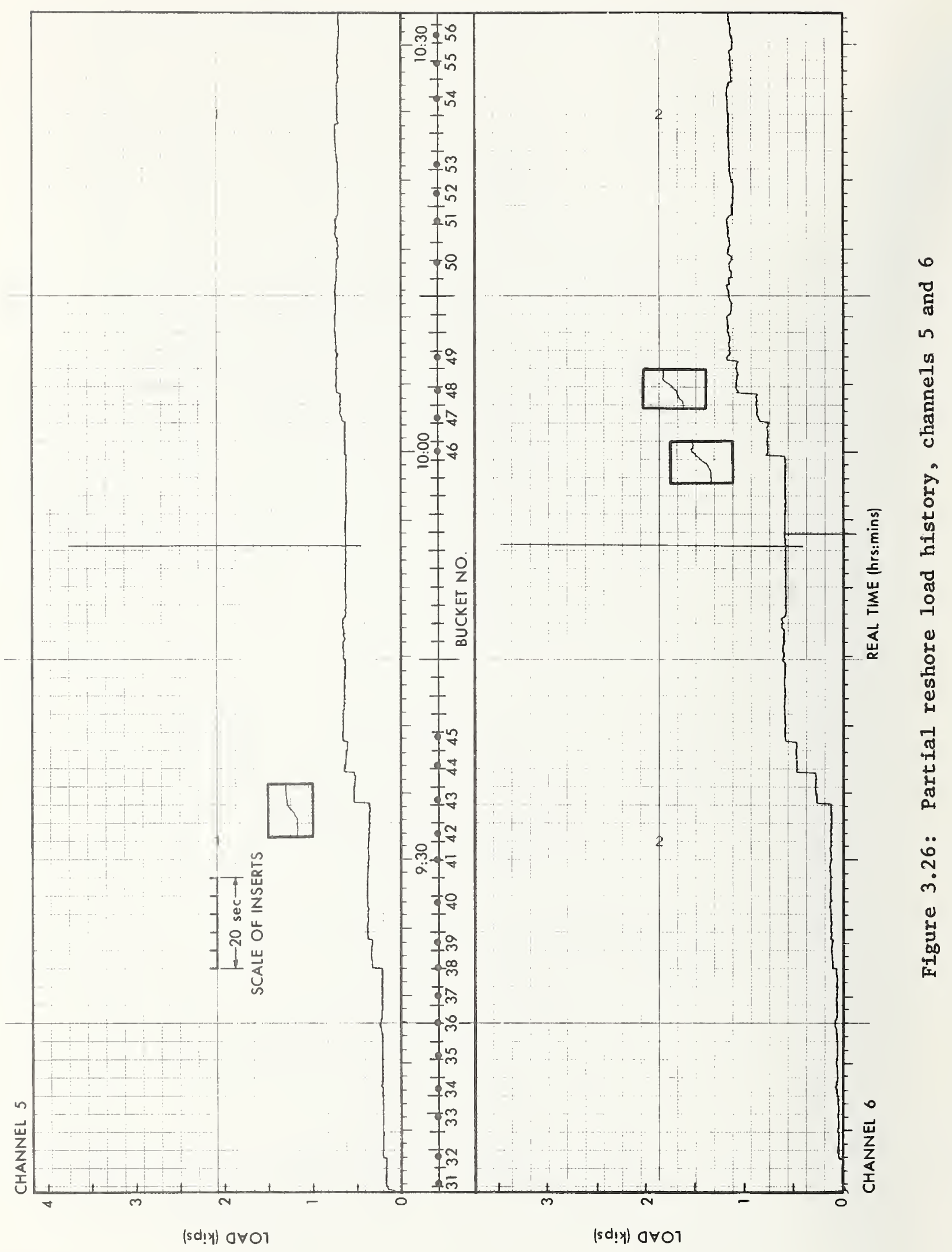




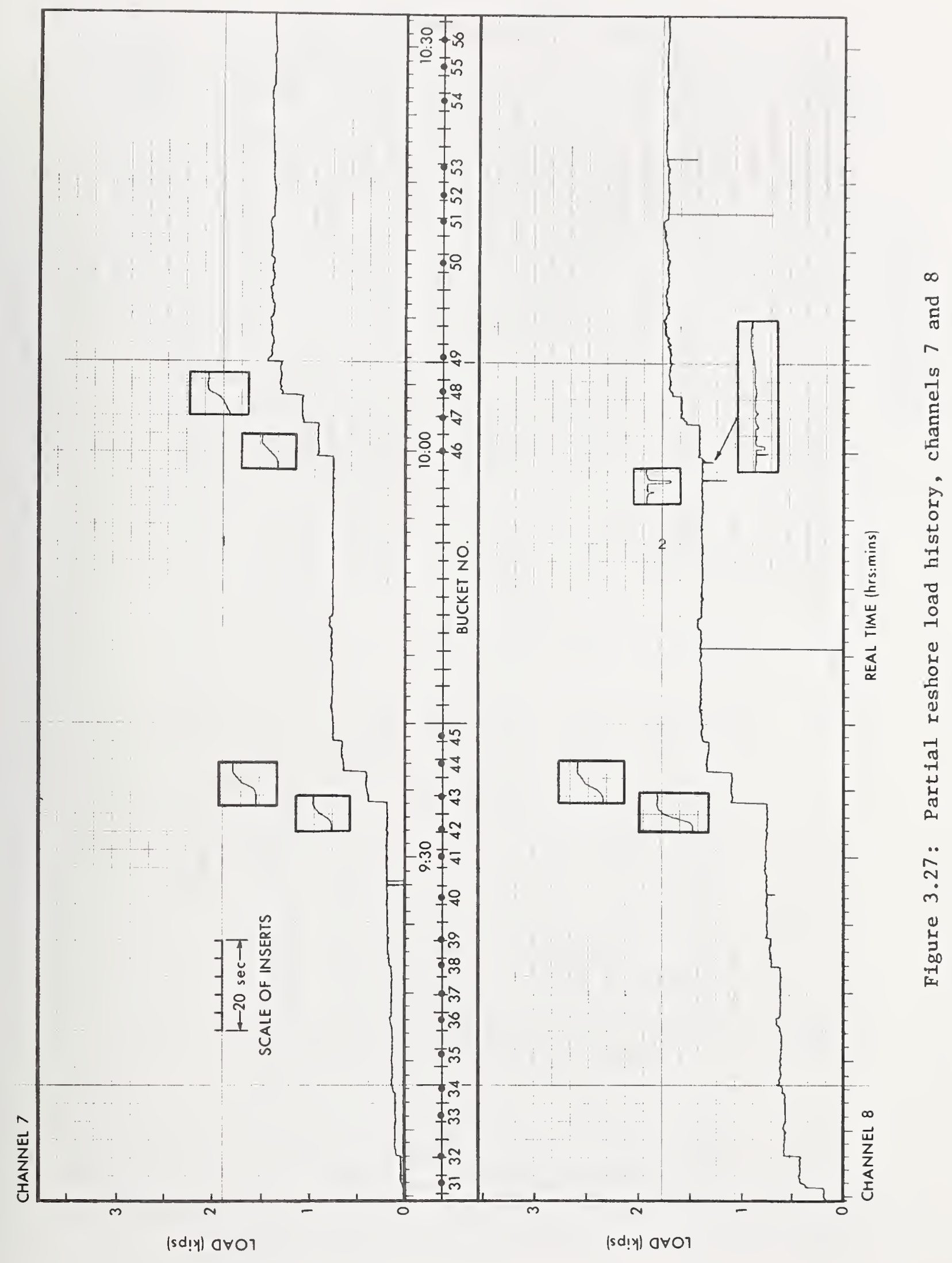




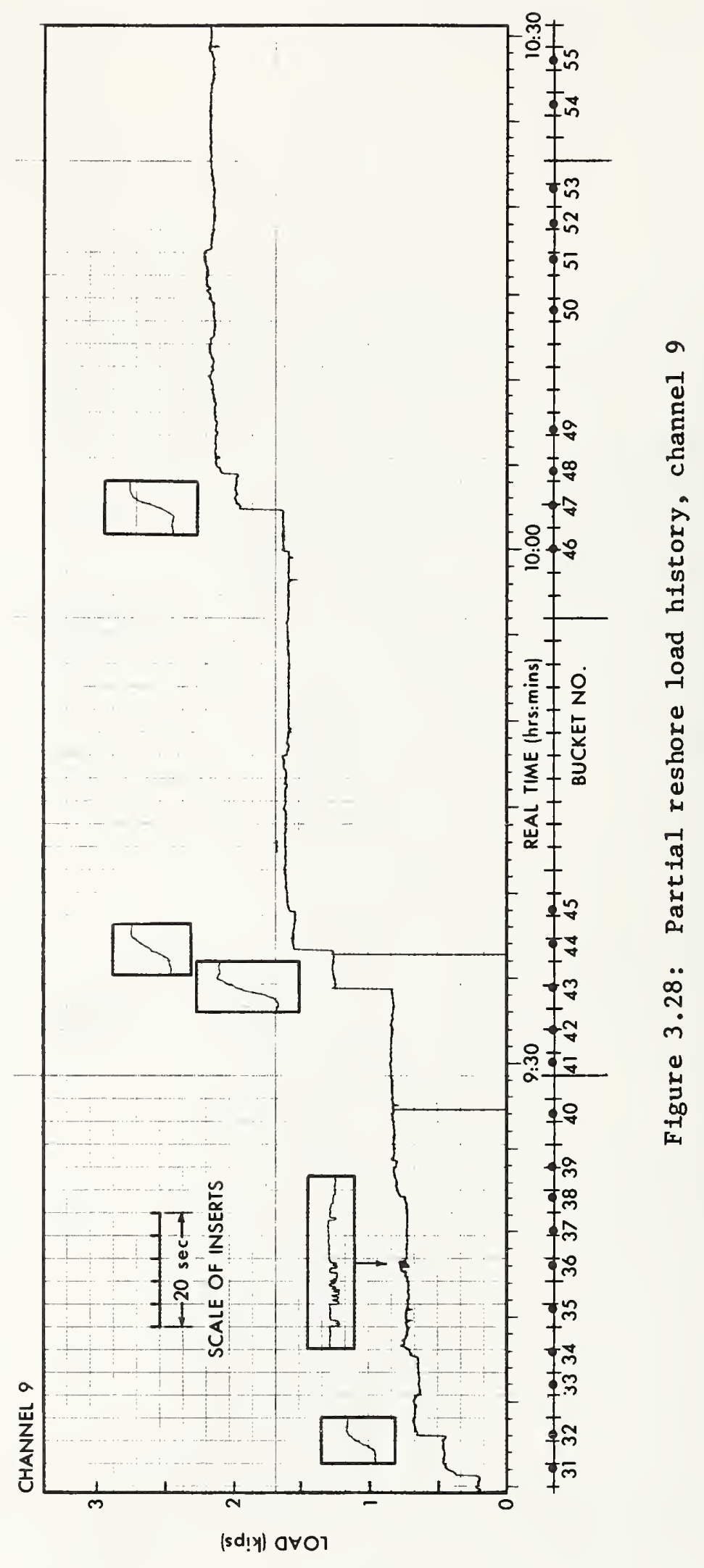




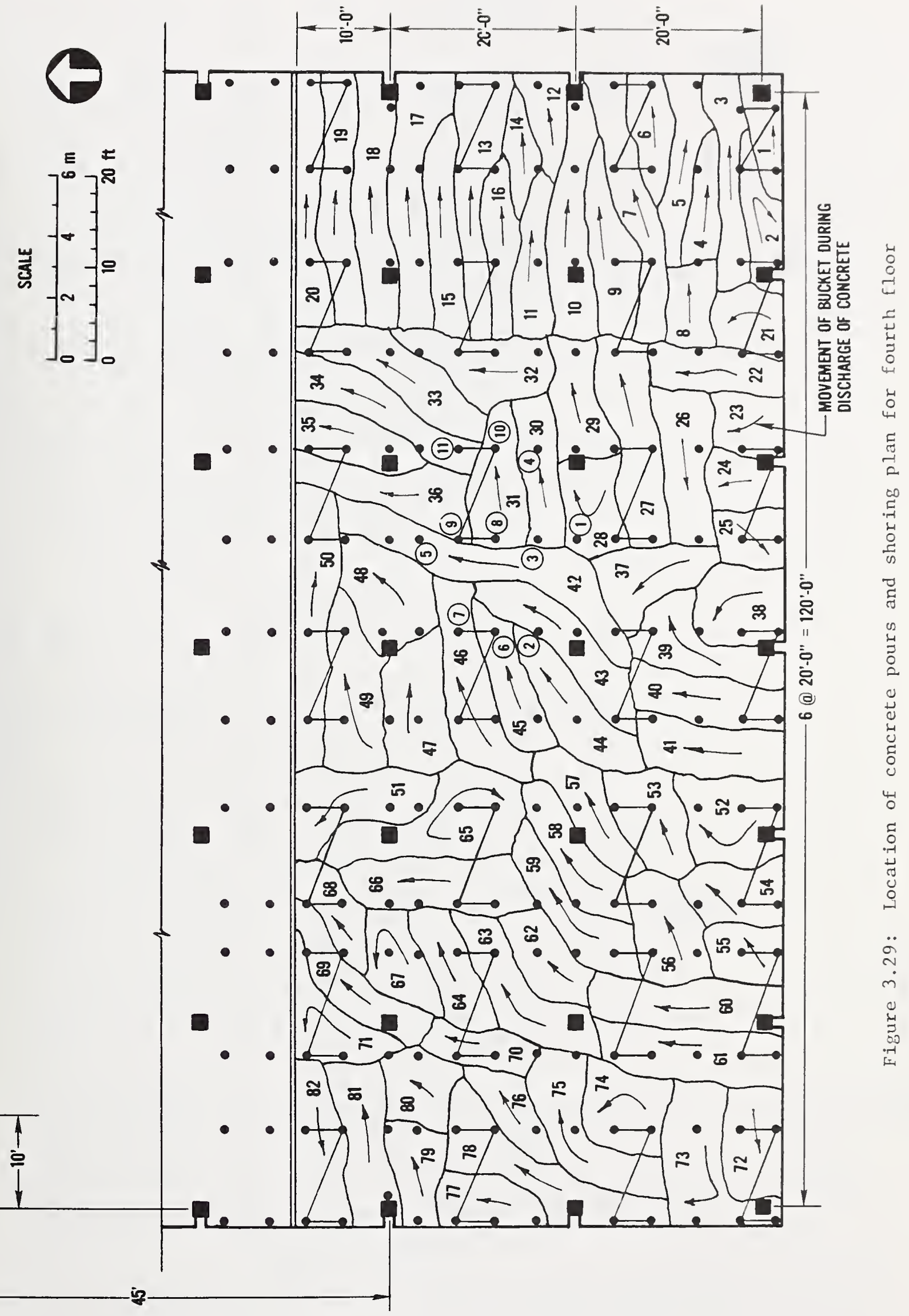




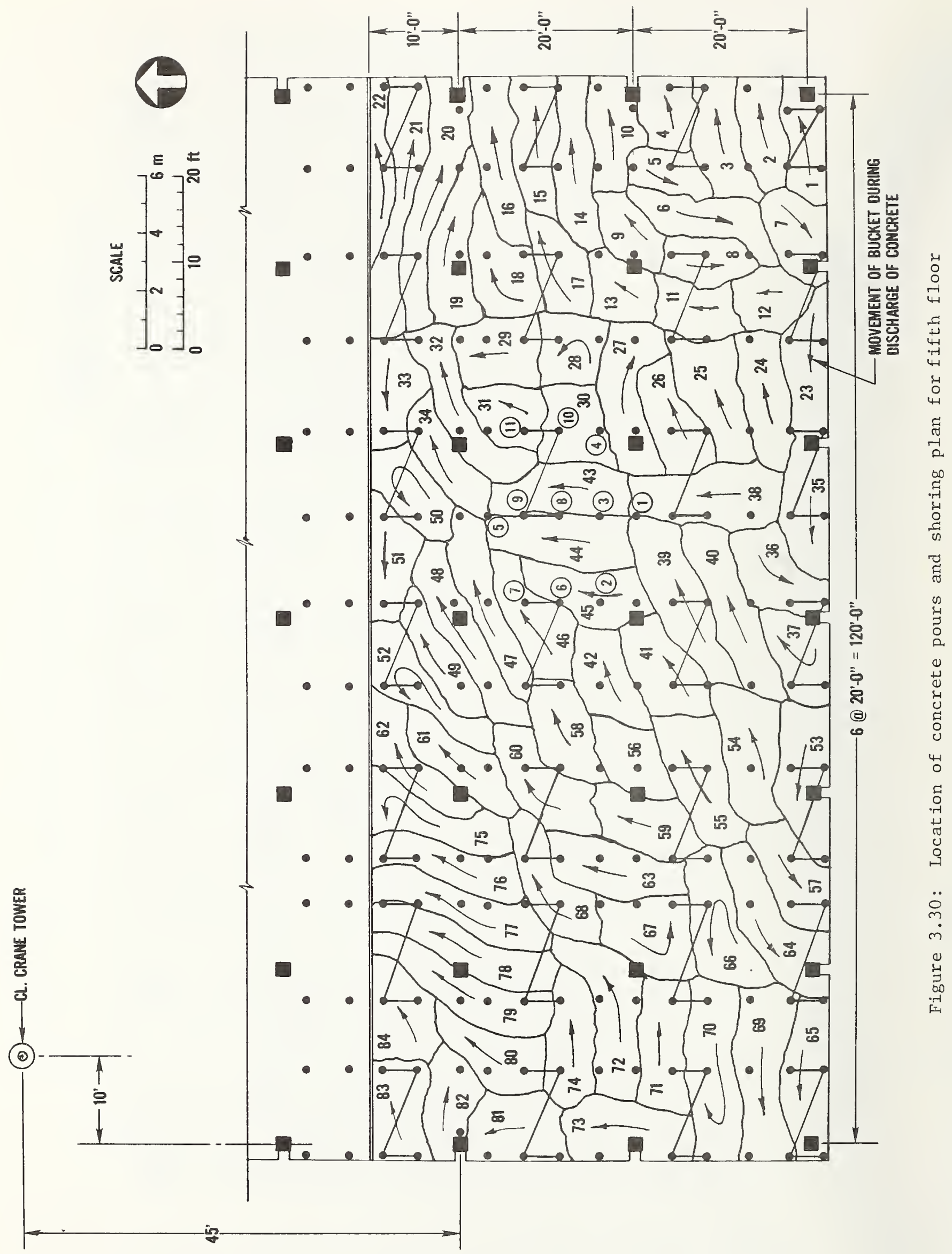




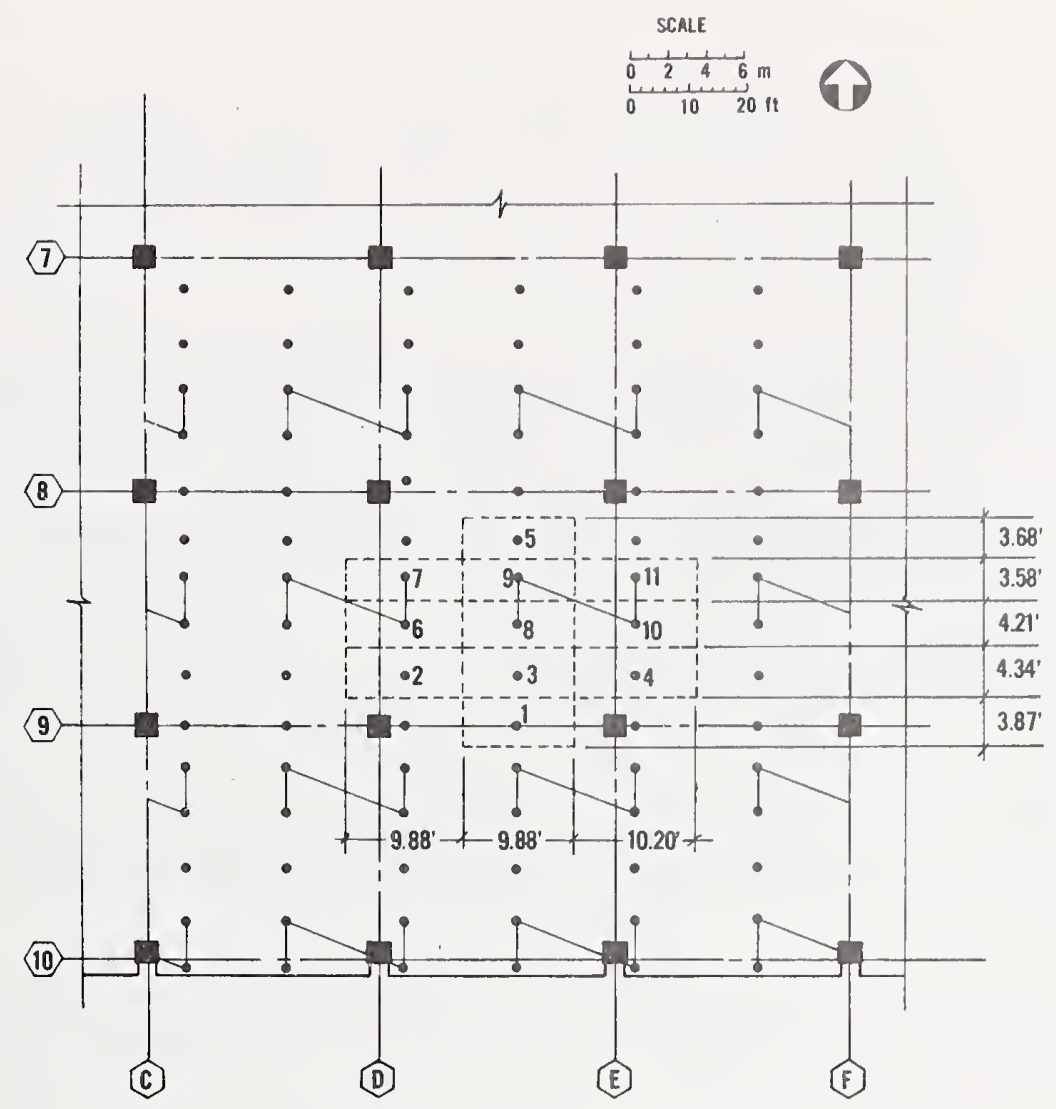

(a) Tributary areas

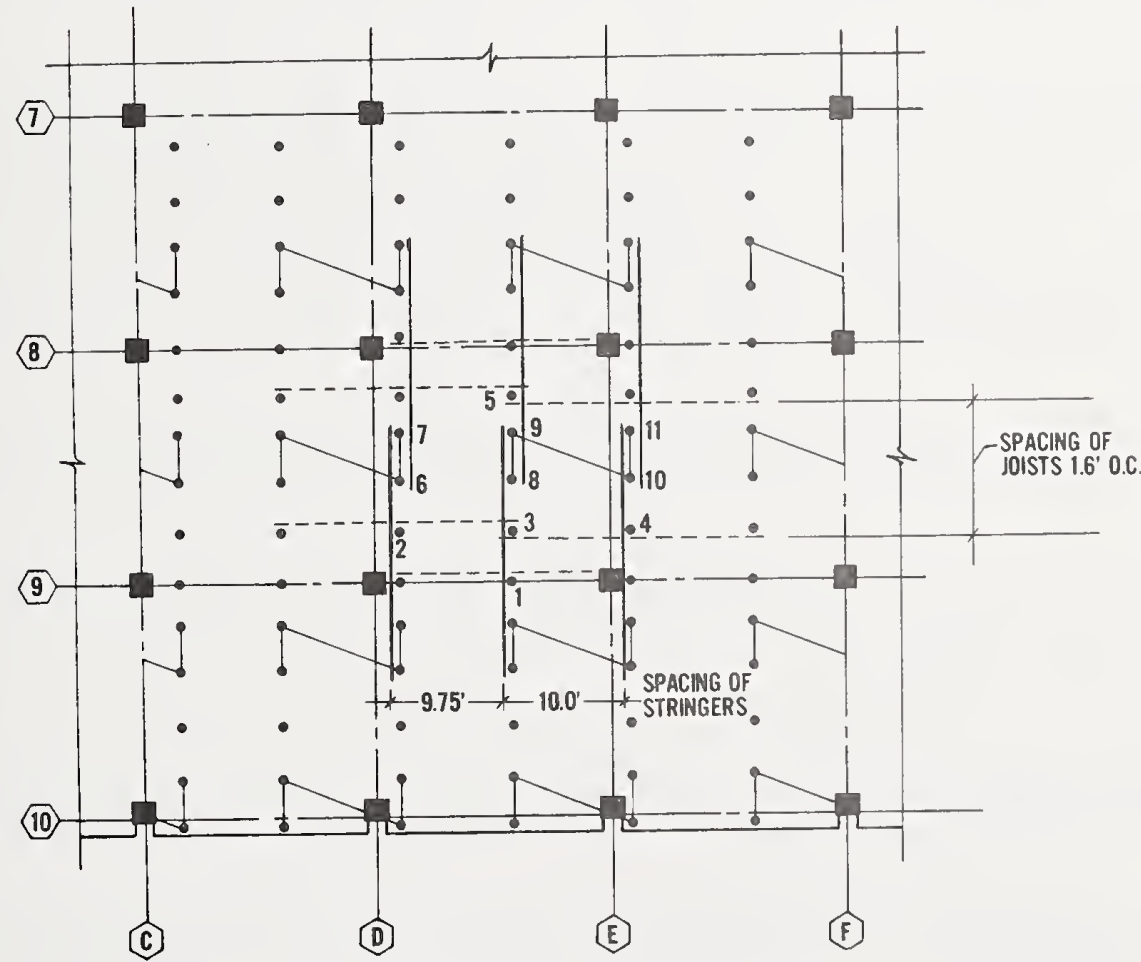

(b) Distribution through beam support system

Figure 4.1: Bases for calculated static loads 


\section{REFERENCES}

1. Research Needs in Civil Engineering, Civil Engineering Journal, ASCE, New York, N.Y., December 1979.

2. Lasisi, Mohammed Y. I., Formwork and Shoring to Floors of Multi-Storey Flat-Slab Buildings, Master's Thesis, University of Ottawa, Ottawa, Canada, 1976.

3. Nielsen, Knud E. C., Loads on Reinforced Concrete Floor Slabs and Their Deformations During Construction, Proceedings Swedish Cement and Concrete Research Institute, No. 15, Stockholm, Sweden, 1952.

4. Grundy, Paul, and Kabaila, A., Construction Loads on Slabs with Shored Formwork in Multistory Buildings, Journal of the American Concrete Institute, December, 1963.

5. Beresford, F. D., An Analytical Examination of Propped Floors in MultiStorey Flat Plate Construction, Constructional Review, Vol. 37, Australia, November 1964.

6. Blakeley, F. A., and Beresford, F. D., Stripping of Formwork for Concrete in Buildings in Relation to Structural Design, Civil Engineering Transactions, Institute of Engineers, Australia, October 1965.

7. Taylor, P. J., Effect of Formwork Stripping Time on Deflections of Flat Slabs and Plates, Australian Civil Engineering and Construction, Vol. 8, No. 2, February 1967 .

8. Marosszeky, M., Construction Loads Imposed on Multi-Storey Structures, Civil Engineering Transactions, Institution of Engineers, Australia, Apr11 1972.

9. Agarwal, R. K., An Experimental Investigation of Shoring Systems for HighRise Flat-Slab Structures, Master's Thesis, University of Ottawa, Ottawa, Canada, May 1972.

10. Agarwal, R. K. and Gardner, Noel, J., Form and Shore Requirements for Multistory Flat Slab Type Buildings, Journal of the American Concrete Institute, November 1974.

11. Lasisi, Mohammed $\mathrm{Y}$. and $\mathrm{Ng}$, Simon F., Construction Loads Imposed on HighRise Floor Slabs, Concrete International, The American Concrete Institute, February 1979.

12. ASTM C31-69, Standard Method of Making and Curing Concrete Test Specimens in the Field, ASTM Standards, Part 14, 1979. 
13. ASTM C39-72, Standard Test Method for Compressive Strength of Cyindrical Concrete Specimens, ASTM Standards, Part 14, 1979.

14. Fattal, S. G., Cattaneo, L. E., Turner, G. E., and Robinson, S. N., Personnel Guardrails for the Prevention of Occupational Accidents, NBSIR 76-1132, National Bureau of Standards, Washington, D.C., July 1976.

15. ACI Standard 347-68, Recommended Practice for Concrete Formwork, American Concrete Institute, Detroit, Michigan, 1968.

16. ANSI A10.9-1970, Safety Requirements for Concrete Construction and Masonry Work, American National Standards Institute, New York, New York, 1970. 
APPENDIX A
Slab Reinforcement Details
and Selected Specifications 
NOTES FOR REINFORCED CONCRETE

A11 reinforced concrete details shall be in accordance with A.C.I. 315 .

A11 reinforced concrete for framed slabs, beams, girders and walls shall have a 28 day compressive strength of 3000 p.s.i. except as noted. See notes on column schedule for strengths of concrete for columns. Walls engaging columns shall have the same strength concrete as the column.

A11 reinforcing steel shall be high strength billet steel conforming to ASTM specification A615-60, and all reinforcing bars not noted to be $\#$.

Deformations shall be in accordance with ASTM A-305.

Al1 reinforcing bars sha11 be continuous or lapped not less than 36 bar diameters where spliced, or unless otherwise noted or shown.

Where main reinforcement of beams and slabs is not continuous with adjacent beams and slabs, top bars shall be extended 36 bar diameters beyond the centerline of support where possible, otherwise the end bars shall be hooked beyond the centerline of support.

Where bar lengths are given on drawings, the length of hook, if any, is not included.

Slabs under concrete walls shall be adequately shored until walls have set.

Place the first slab bar a distance of one-half the normal bar spacing from face of wall or beam.

Concrete protection for reinforcement:

beams and columns $=1 \frac{1}{2} "$

slabs $=3 / 4^{\prime \prime}$

walls: exterior face $=2^{\prime \prime}$ and interior face $=3 / 4^{\prime \prime}$

Provide spacers, chairs, ties, etc. as required and necessary for assembling, placing and supporting all reinforcing in place.

All concrete shall be vibrated, using deep spade type for walls and columns of such length to extend to within two feet of bottom of wall or column.

Vertical wall or column bars when spliced at a framed door shall be lapped at least 30 bar diameters of the upper size bar.

Welded wire mesh to conform to ASTM A-185 and to be placed as indicated on drawings. Lap edges of wire mesh at least 6" in each direction. Fs $=25,000$ p.s.i. 


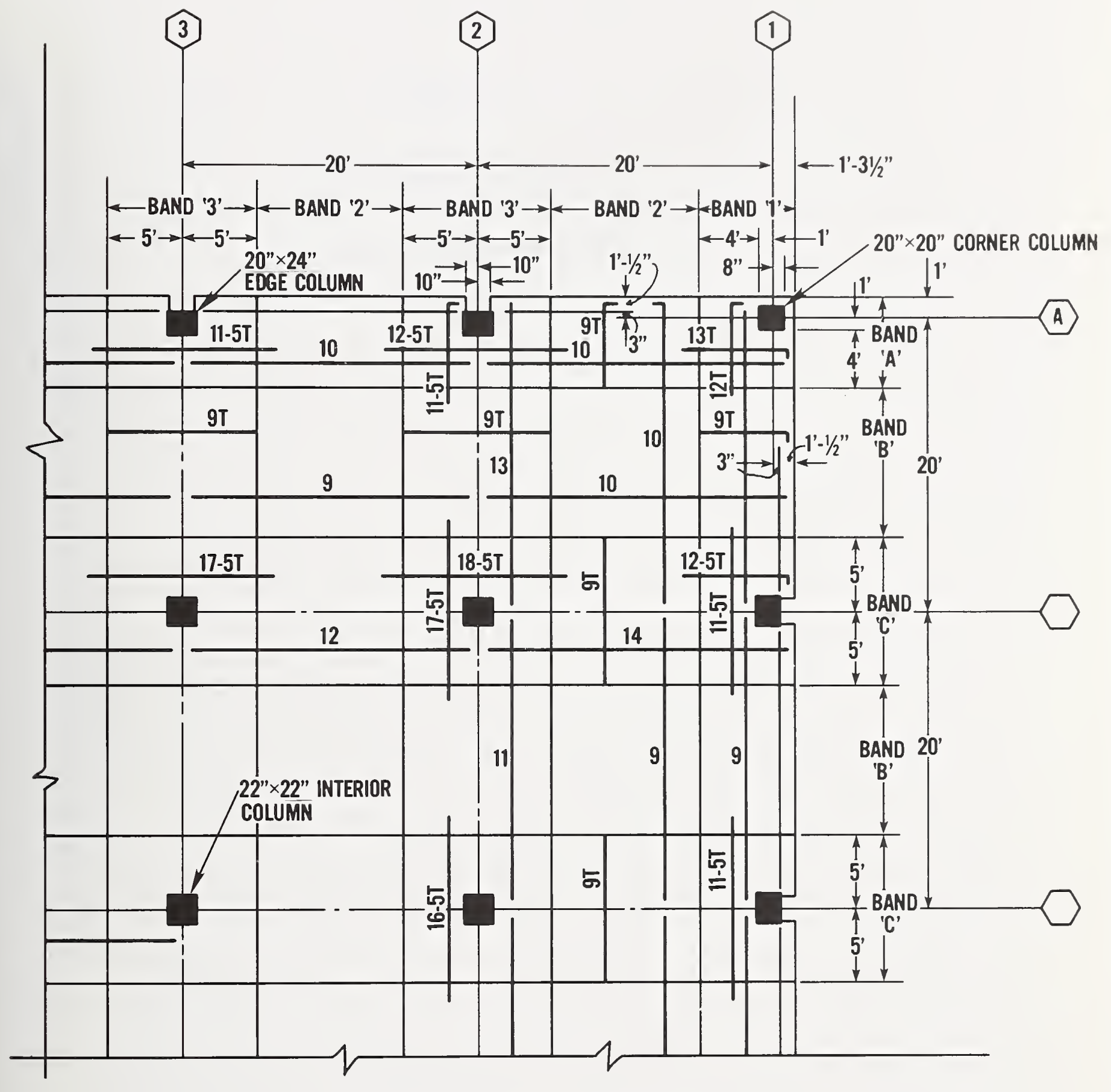

Typical Slab Reinforcement Layout 



\author{
APPENDIX B \\ Construction Schedule \\ and \\ Concrete Cylinder Test Data
}

$B-1$ 
Table B.1 Sequence of construction

\begin{tabular}{|c|c|c|c|c|}
\hline \multirow[b]{2}{*}{ Day } & \multicolumn{3}{|c|}{ Ambient Condition } & \multirow[b]{2}{*}{$\begin{array}{l}\text { Construction } \\
\text { Activity }\end{array}$} \\
\hline & $\begin{array}{l}\text { Low } \\
\text { Temp. } \\
\text { (F) }\end{array}$ & $\begin{array}{l}\text { High } \\
\text { Temp. } \\
\text { (F) }\end{array}$ & $\begin{array}{l}\text { Weather } \\
\text { Code }\end{array}$ & \\
\hline $2 / 26$ & 28 & 38 & $C, W$ & Cast ftgs. A8-A12, $\mathrm{C} 8-\mathrm{C} 12, \mathrm{E} 10-\mathrm{E} 12$ \\
\hline $2 / 27$ & 27 & 38 & $\mathrm{C}$ & $\begin{array}{l}\text { Cast ftgs. B11, B12, D8-D12, E8, E9 } \\
\text { F8-F12 }\end{array}$ \\
\hline $2 / 28$ & 29 & 35 & s & - \\
\hline $2 / 29$ & 5 & & & - \\
\hline $3 / 3$ & 10 & 33 & & - \\
\hline $3 / 4$ & 25 & 50 & $\mathrm{C}$ & $\begin{array}{l}\text { Cast ftgs. B8-B10, G8-G12, I8-I12; } \\
\text { cast part S wall ftg. }\end{array}$ \\
\hline $3 / 5$ & & & $\mathrm{R}$ & 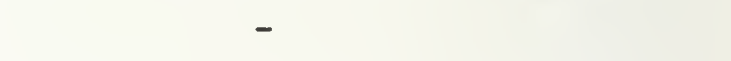 \\
\hline $3 / 6$ & 42 & 63 & S & Cast ftgs. A1-A7, B7, C7, E7, H8-H12 \\
\hline $3 / 7$ & 36 & 65 & S & $\begin{array}{l}\text { Cast ftgs. B1-B6, D7, E6, F6, F7, G6, } \\
\text { G7, H7, I7 }\end{array}$ \\
\hline $3 / 10$ & 34 & & & $\begin{array}{l}\text { Cast ftgs. C5A, C6A, C6B, D5, D6, D6A, } \\
\text { F5, G5, H5, H6, I6; cast part W wal1 }\end{array}$ \\
\hline $3 / 11$ & 42 & 46 & S, W & $\begin{array}{l}\text { Cast ftgs. C1-C3, E5, F4, G4, H4, I4, } \\
\text { I5; strip wall cast } 3 / 10\end{array}$ \\
\hline $3 / 12$ & 27 & 38 & S & $\begin{array}{l}\text { Cast ftgs. D1, D2, C5, C6, C7A, E1, } \\
\text { E4, F1, F3, G3, H3, I3; cast part E } \\
\text { wa11 ftg. }\end{array}$ \\
\hline $3 / 13$ & & 34 & SN & - \\
\hline $3 / 14$ & & & SN & - \\
\hline $3 / 17$ & 52 & 58 & $\mathrm{R}$ & - \\
\hline $3 / 18$ & 52 & 57 & $R, S$ & $\begin{array}{l}\text { Cast ftgs. C4, D3, D4, D4A, E3, E4, } \\
\text { E5A, E6A; cast } 112 \text { ' S wa11 }\end{array}$ \\
\hline $3 / 19$ & 39 & 60 & S & $\begin{array}{l}\text { Cast ftgs. C4A, F2, G1, G2, H1, H2, } \\
\text { I1, T2; cast part S wall ftg. }\end{array}$ \\
\hline $3 / 20$ & 47 & 57 & $\mathrm{~S}$ & $\begin{array}{l}\text { Cast part } W \& S E \text { walls, part } E \text { wall } \\
\text { ft. }\end{array}$ \\
\hline
\end{tabular}


Table B.1 - Cont.

\begin{tabular}{|c|c|c|c|c|}
\hline \multirow[b]{2}{*}{ Day } & \multicolumn{3}{|c|}{ Ambient Condition } & \multirow[b]{2}{*}{$\begin{array}{l}\text { Construction } \\
\text { Activity }\end{array}$} \\
\hline & $\begin{array}{l}\text { Low } \\
\text { Temp. } \\
\text { (F) }\end{array}$ & $\begin{array}{l}\text { High } \\
\text { Temp. } \\
\text { (F) }\end{array}$ & $\begin{array}{l}\text { Weather } \\
\text { Code }\end{array}$ & \\
\hline $3 / 21$ & 60 & 63 & R & - \\
\hline $3 / 24$ & 48 & 54 & $\mathrm{C}$ & Strip wall \\
\hline $3 / 25$ & 51 & 60 & s & Cast part E wa11, crane pad; strip walls \\
\hline $3 / 26$ & 48 & 60 & S & $\begin{array}{l}\text { Strip E wall, cast part E wall \& } 5800 \text { sf } \\
\text { ground slab }\end{array}$ \\
\hline $3 / 27$ & 37 & 54 & $\mathrm{~s}$ & $\begin{array}{l}4800 \text { sf ground slab cast } \# 2 \text {; cast } 60^{\prime} \mathrm{NE} \\
\text { wall; strip E wall }\end{array}$ \\
\hline $3 / 28$ & 48 & 50 & C & $\begin{array}{l}\text { Cast } 6000 \text { sf ground slab \& part W wall; } \\
\text { strip walls }\end{array}$ \\
\hline $3 / 31$ & 48 & 54 & R & - \\
\hline $4 / 1$ & 46 & 61 & s & $\begin{array}{l}\text { Framing sects. } 1 \& 2 \text { of } F 1.1 \text {; strip } \\
\text { walls; cast part of } W \& N \text { walls }\end{array}$ \\
\hline $4 / 2$ & 45 & 69 & S & $\begin{array}{l}\text { Cast cols. } \mathrm{D} 12, \mathrm{E} 12, \mathrm{~F} 12, \mathrm{G} 12, \mathrm{C} 11, \mathrm{D} 11 \text {, } \\
\mathrm{E} 11, \mathrm{~F} 11, \mathrm{G} 11, \mathrm{C} 10, \mathrm{D} 10, \mathrm{E} 10 \text {; framing } \\
\text { sects. } 1 \& 2, \mathrm{f} 1.1 \text {; strip W \& S walls }\end{array}$ \\
\hline $4 / 3$ & 52 & 69 & s & $\begin{array}{l}\text { Cast cols. H11, H12, Ill, I12 \& bott. } \\
\text { elev. pit; framing sects. } 1-3 \text { to fl.1; } \\
\text { strip walls; cast } 7200 \text { sf SOG }\end{array}$ \\
\hline $4 / 4$ & 57 & 62 & $R, S$ & Erect framing for sect. $2 \mathrm{f} 1.1$ \\
\hline $4 / 5$ & 42 & 70 & S & Erect framing for sect. $2 \mathrm{f} 1.1$ \\
\hline $4 / 7$ & 59 & 70 & S & $\begin{array}{l}\text { Framing sects. } 1-3 \& \text { elev. shaft @ SOG; } \\
\text { cast cols. C9, E9, F9, G9, H9, I9, F10, } \\
\text { G10, H10, I8 C12\& } 4000 \text { sf SOG }\end{array}$ \\
\hline $4 / 8$ & 57 & 62 & $S$ & $\begin{array}{l}\text { Framing sects. } 1-4 \& \text { core area } @ \text { SOG; } \\
\text { cast } 4800 \text { sf SOG \& cols. in sects. } 3,4\end{array}$ \\
\hline $4 / 9$ & 61 & 70 & $\mathrm{R}, \mathrm{S}$ & Framing sects. 1,3 \\
\hline $4 / 10$ & 61 & 68 & S & $\begin{array}{l}\text { Cast cols. G6-G8, H6, H7, F6, F7, E7, } \\
\text { D7, C7, B7, B6; framing sects. } 3,4 ; \\
\text { cast } 5200 \text { sf SOG }\end{array}$ \\
\hline
\end{tabular}


Table B.1 - Cont.

\begin{tabular}{|c|c|c|c|c|}
\hline \multirow[b]{2}{*}{ Day } & \multicolumn{3}{|c|}{ Ambient Condition } & \multirow[b]{2}{*}{$\begin{array}{l}\text { Construcition } \\
\text { Activity }\end{array}$} \\
\hline & $\begin{array}{l}\text { Low } \\
\text { Temp. } \\
\text { (F) }\end{array}$ & $\begin{array}{l}\text { High } \\
\text { Temp. } \\
\text { (F) }\end{array}$ & $\begin{array}{l}\text { Weather } \\
\text { Code }\end{array}$ & \\
\hline $4 / 11$ & 61 & 77 & S & $\begin{array}{l}\text { Framing sects. } 3 \& 4 \text {; cast sect. } 2 \text { f } 1.1 \\
\& \text { Cols. @ sects. } 5 \& 6\end{array}$ \\
\hline $4 / 14$ & 61 & & $\mathrm{R}$ & $\begin{array}{l}\text { Framing sects. } 3 \& 4 \& \text { cols. sects. } 5 \& \\
6 \mathrm{f} 1.1\end{array}$ \\
\hline $4 / 15$ & 58 & 61 & S & $\begin{array}{l}\text { Framing sects. } 3 \& 4 \& \text { cols. to fl.1 } \\
\text { cast } 8000 \text { sf SOG \& cols. sects, } 5 \& 6 \mathrm{f} 1.1\end{array}$ \\
\hline $4 / 16$ & & & $\mathrm{~s}$ & $\begin{array}{l}\text { Framing sects. } 4 \& 5 \& \text { cols. sects. } 7 \& 8 \text {; } \\
\text { place steel sect. } 3 \text {; cast sect. } 1 \text { of fl.1 } \\
\& \text { cols. in sect. } 7 \& \text { part sect. } 8\end{array}$ \\
\hline $4 / 17$ & 57 & 60 & s & $\begin{array}{l}\text { Framing sect. } 5 \text {; place steel in sect. } 4 \text {; } \\
\text { cast sect. } 3 \& \text { cols. sects. } 7 \& 9\end{array}$ \\
\hline $4 / 18$ & 55 & 68 & s & $\begin{array}{l}\text { Framing sects. } 5 \& 6 \mathrm{f} 1.1 \text { \& cols. to } \mathrm{f} 1.2 \text {; } \\
\text { place stee } 1 \text { in sect. } 4 \mathrm{f} 1.1 \text { \& cols. to } \\
\mathrm{f} 1.2 \text {; cast cols. } \mathrm{B} 8, \mathrm{~B} 9, \mathrm{C} 9, \mathrm{D} 9, \mathrm{E} 9 \text { to } \\
\mathrm{f} 1.2\end{array}$ \\
\hline $4 / 21$ & 55 & 71 & s & $\begin{array}{l}\text { Framing sects. } 6,7 \mathrm{f} 1.1 \text { \& Cols. to } \mathrm{f} 1.2 \\
\text { place steel in sect. } 5 \mathrm{f} 1.1 \text {; strip sect. } \\
2 \mathrm{f} 1.1 \text {; cast sect. } 4 \text { \& bal. of cols. to } \\
\mathrm{f} 1.1 \& 3 \text { cols to } \mathrm{f} 1.2\end{array}$ \\
\hline $4 / 22$ & 55 & 74 & s & $\begin{array}{l}\text { Framing sects. } 7 \& 8 \mathrm{f} 1.1 \text { \& cols. to } \mathrm{f} 1.2 \text {; } \\
\text { strip sect. } 2 \mathrm{f} 1.1 ; \mathrm{p} 1 \text { ace stee } 1 \text { in sect. } \\
6 \mathrm{f} 1.1 \& \text { cols. to } \mathrm{f} 1.2\end{array}$ \\
\hline $4 / 23$ & 61 & 77 & S & $\begin{array}{l}\text { Framing sects. } 8 \& 9 \mathrm{f} 1.1 \text { \& sect. } 1 \mathrm{f} 1.2 \text {; } \\
\text { place stee } 1 \text { in sect. } 7 \mathrm{f} 1.1 \text {; cast sect. } \\
6 \mathrm{f} 1.1 \text {, bal. of SOG \& part of cols. to } \\
\mathrm{f} 1.2 \text { under sect. } 2\end{array}$ \\
\hline $4 / 24$ & 61 & 78 & $\mathrm{~s}$ & $\begin{array}{l}\text { Framing sects. } 9 \& 10 \mathrm{f} 1.1 ; \text { place steel } \\
\text { in sect. } 8 \text {; cast sect. } 7 \text { of fl.1 \& part } \\
\text { cols. to } 1.2 \text { under sect. } 2 \text {; strip sect. } \\
3 \mathrm{f} 1.1\end{array}$ \\
\hline $4 / 25$ & 62 & 77 & s & $\begin{array}{l}\text { Framing sects. } 9 \& 10 \mathrm{f} 1.1 \text {; place steel } \\
\text { in sect. } 9 \text {; strip sects. } 2 \text { \& } 3 \mathrm{fl} .1 \text {; } \\
\text { cast sect. } 8 \mathrm{f} 1.1 \text { \& part cols. under } \\
\text { sect. } 3 \text { to } \mathrm{f} 1.2\end{array}$ \\
\hline
\end{tabular}


Table B.1 - Cont.

\begin{tabular}{|c|c|c|c|c|}
\hline \multirow[b]{2}{*}{ Day } & \multicolumn{3}{|c|}{ Ambient Condition } & \multirow[b]{2}{*}{$\begin{array}{l}\text { Construction } \\
\text { Activity }\end{array}$} \\
\hline & $\begin{array}{l}\text { Low } \\
\text { Temp. } \\
\text { (F) }\end{array}$ & $\begin{array}{l}\text { High } \\
\text { Temp. } \\
\text { (F) }\end{array}$ & $\begin{array}{l}\text { Weather } \\
\text { Code }\end{array}$ & \\
\hline $4 / 26$ & & & R & $\begin{array}{l}\text { Framing bulkheads in sect. } 9 \mathrm{fl} 1.1 \text { \& cols. } \\
\text { to f1.2; strip sects. } 3 \text { \& } 5 \mathrm{f} 1.1 \text {; cast } \\
\text { cols. A10, B10, C10, D10, F4, F5, E5A to } \\
\text { F1.2 }\end{array}$ \\
\hline $4 / 29$ & 57 & 62 & $\mathrm{C}, \mathrm{s}$ & $\begin{array}{l}\text { Framing sect. } 10 \mathrm{f} 1.1 \& \text { sect. } 1 \mathrm{f} 1.2 \text {; } \\
\text { place stee } 1 \text { in sect. } 10 \text { \& cols. to } \\
\mathrm{f} 1.2 \text {; strip sects. } 1,3 \& 5 \mathrm{f} 1.1 \text {; cast } \\
\text { sect. } 9 \mathrm{f} 1.1 \& \text { cols. A9, E } 10, \mathrm{~F} 10 \text {, C10 } \\
\text { to } \mathrm{f} 1.2\end{array}$ \\
\hline $4 / 30$ & 57 & 63 & $\mathrm{R}$ & $\begin{array}{l}\text { Framing parapet } \mathrm{f} 1.1 \text { \& sects. } 1 \text { \& } 2 \mathrm{f} 1.2 \text {; } \\
\text { strip sects. } 1,3 \& 4 \mathrm{f} 1.1 \text {; cast cols. } \\
\mathrm{A} 8, \mathrm{G} 7, \mathrm{G} 8, \mathrm{G} 9, \mathrm{~B} 3, \mathrm{C} 2, \mathrm{C} 3, \mathrm{D} 3, \mathrm{E} 3\end{array}$ \\
\hline $5 / 1$ & & & $\mathrm{R}$ & $\begin{array}{l}\text { Framing sect. } 2 \mathrm{f} 1.2 \text {; strip sect. } 3,4 \\
\& 5 \mathrm{fl} .1 \text {; cast cols. G4-G6, A7 to fl.2 }\end{array}$ \\
\hline $5 / 2$ & 62 & 71 & S & $\begin{array}{l}\text { Framing sects. } 2,3 \mathrm{f} 1.2 \text { \& parapet wal1 } \\
\text { top of ramp. strip sects. } 5 \text { \& } 6 \mathrm{f} 1.1 \text {; } \\
\text { place stee1 in sect. } 1 \text { of } \mathrm{f} 1.2 \text {; cast } \\
\text { sect. } 10 \mathrm{f} 1.1 \text { \& cols. B2, } 22, \mathrm{E} 2 \text {, A6, } \\
\mathrm{B} 6, \mathrm{C} 6 \text {, C5 to } \mathrm{f} 1.2\end{array}$ \\
\hline $5 / 5$ & 61 & 82 & S & $\begin{array}{l}\text { Framing sects. } 2,3 \mathrm{f} 1.2 \text {; strip sects. } \\
5,6 \mathrm{f} 1.1 \text {; cast sect. } 1 \text { \& cols. F2, F3, } \\
\mathrm{B} 5, \mathrm{~A} 5, \mathrm{~A} 4, \mathrm{~A} 3 \text { to } \mathrm{f} 1.2\end{array}$ \\
\hline $5 / 6$ & 62 & 86 & s & $\begin{array}{l}\text { Framing sects. } 2-4 \mathrm{f} 1.2 \text { \& cols. to } \mathrm{f} 1.3 \text {; } \\
\text { place steel sect. } 2 \mathrm{fl} 1.2 \text {; strip sects. } 7 \text {, } \\
8 \mathrm{fl} 1 \text {; cast cols. Cl, D1, G2, G3 to } \mathrm{fl} .2 \\
\& \mathrm{cols} \text {. A10, B10, C10, D10, E10, F10, } \\
\text { G10, F9, E9, D9 to } \mathrm{f} 1.3\end{array}$ \\
\hline $5 / 7$ & 65 & 80 & s & $\begin{array}{l}\text { Framing sect. } 4 \mathrm{f} 1.2 \text { \& cols. to } \mathrm{f} 1.3 \text {; } \\
\text { strip sect. } 9 \mathrm{fl} 1.1 \text {; place steel in sect. } \\
3 \mathrm{f} 1.2 \text {; cast sect. } 2 \mathrm{f} 1.2 \text {, N parapet @ } \\
\text { ramp, cols. A9, B9, C9, G9, A8, B8, C8, } \\
\text { D8, E8, G8 to } \mathrm{f} 1.3 \text { \& cols. B1, E1, G1, } \\
\text { F1 to } \mathrm{f} 1.2\end{array}$ \\
\hline $5 / 8$ & 67 & 78 & $\mathrm{R}$ & $\begin{array}{l}\text { Framing sect. } 1 \mathrm{f} 1.2 \text { \& cols. to } \mathrm{f} 1.3 \text {; } \\
\text { strip sect. } 9 \mathrm{fl} .1 \text {; cast cols. A1, A2 } \\
\text { to } \mathrm{f} 1.2\end{array}$ \\
\hline $5 / 9$ & 49 & 57 & S & $\begin{array}{l}\text { Framing sect. } 1 \mathrm{f} 1.3 \text { \& cols. sect. } 2 \text { to } \\
\mathrm{f} 1.3 \text {; place steel sect. } 4 \mathrm{fl} .2 \text {; strip } \\
\text { sect. } 9 \mathrm{fl} 1.1 \text {; cast sect. } 3 \mathrm{fl} .2 \text {, cols. } \\
\text { under sect. } 2 \text { to } \mathrm{f} 1.3 \text { \& ret. wall } \mathrm{ftg} \text {. }\end{array}$ \\
\hline
\end{tabular}


Table B.1 - Cont.

\begin{tabular}{|c|c|c|c|c|}
\hline \multirow[b]{2}{*}{ Day } & \multicolumn{3}{|c|}{ Ambient Condition } & \multirow[b]{2}{*}{$\begin{array}{l}\text { Construction } \\
\text { Activity }\end{array}$} \\
\hline & $\begin{array}{l}\text { Low } \\
\text { Temp. } \\
(F)\end{array}$ & $\begin{array}{l}\text { High } \\
\text { Temp. } \\
(F)\end{array}$ & $\begin{array}{l}\text { Weather } \\
\text { Code }\end{array}$ & \\
\hline $5 / 12$ & 67 & 83 & s & $\begin{array}{l}\text { Framing sects. } 1 \& 2 \mathrm{fl} .3 \text {; strip sect. } 10 \\
\mathrm{f} 1.1 \text {; cast sect. } 4 \mathrm{f} 1.2 . \& \text { cols. under sect. } \\
3 \mathrm{fl} \text {. } 3 \text {; strip sect. } 1 \mathrm{fl} .2\end{array}$ \\
\hline $5 / 13$ & 71 & 90 & $\mathrm{C}$ & $\begin{array}{l}\text { Framing sects. } 2,3 \mathrm{fl} .3 \text {; strip sect. } 1 \\
\mathrm{f} 1.2 \text { \& basement; place steel in sect. } 1 \\
\mathrm{f} 1.3 \text {; cast cols. under sect. } 4 \mathrm{fl} .3\end{array}$ \\
\hline $5 / 14$ & 71 & 90 & s & $\begin{array}{l}\text { Framing sects. } 2-4 \mathrm{fl} .3 \text {; strip sect. } 2 \\
\text { f1.2; cast sect. } 1 \mathrm{fl} .3\end{array}$ \\
\hline $5 / 15$ & 55 & 76 & s & $\begin{array}{l}\text { Framing sect. } 4 \mathrm{f} 1.3 \text { \& cols. sect. } 1 \text { to } \\
\text { fl.4; strip sect. } 3 \mathrm{f} 1.2 \text {; place stee } 1 \\
\text { sect. } 2 \mathrm{fl} .3 \text {; cast cols. under sect. } 1 \\
\text { to } \mathrm{f} 1.4\end{array}$ \\
\hline $5 / 16$ & 71 & 85 & S & $\begin{array}{l}\text { Framing sect. } 1 \mathrm{f} 1.4 ; \text { place steel sect. } \\
3 \mathrm{f} 1.3 \text {; cast sect. } 2 \mathrm{f} 1.3\end{array}$ \\
\hline $5 / 19$ & 74 & 86 & C & $\begin{array}{l}\text { Framing sects. } 1,2 \text { fl.4; place steel } \\
\text { sect. } 4 \mathrm{fl} .3 \text {; strip sect. } 4 \mathrm{fl} 1.2 \text { \& garage; } \\
\text { cast sect. } 3 \mathrm{f} 1.3 \text { \& cols. sect. under f } 1.4\end{array}$ \\
\hline $5 / 20$ & 64 & 72 & $C, R$ & $\begin{array}{l}\text { Strip \& move cols. from sect. } 2 \text { to } 3 \text { under } \\
\text { f1.4; strip bal. fl. } 2 \text { garage area; }\end{array}$ \\
\hline $5 / 21$ & 62 & 71 & $\mathrm{R}$ & \\
\hline $5 / 22$ & 64 & 88 & s & $\begin{array}{l}\text { Framing sect. } 2 \mathrm{f} 1.4 \text {; strip sect. } 1 \mathrm{fl} .3 \text {; } \\
\text { cast sect. } 4 \mathrm{f} 1.3 \text { \& cols. under sect. } 3 \\
\text { to } \mathrm{f} 1.4\end{array}$ \\
\hline $5 / 23$ & 71 & 89 & S & $\begin{array}{l}\text { Framing sect. } 3 \mathrm{fl} 1.4 \text {; strip sect. } 2 \mathrm{fl} .3 \text {; } \\
\text { place steel sect. } 1 \mathrm{f} 1.4 \text {; cast cols. sect. } \\
4 \text { under } \mathrm{f} 1.4\end{array}$ \\
\hline $5 / 27$ & 64 & 85 & s & $\begin{array}{l}\text { Framing sect. } 4 \mathrm{f} 1.4 ; \text { strip sect. } 3 \mathrm{fl} .3 \text {; } \\
\text { place steel in sect. } 2 \mathrm{f} 1.4 ; \text { cast sect. } 1 \\
\mathrm{f} 1.4\end{array}$ \\
\hline $5 / 28$ & 71 & 82 & s & $\begin{array}{l}\text { Framing sect. } 4 \mathrm{f} 1.4 \text { \& ret. wall a ramp; } \\
\text { place steel sect. } 3 \mathrm{f} 1.4 ; \text { strip sects. } \\
3,4 \mathrm{fl} .3 \text {; cast sect } 2 . \mathrm{f} 1.4 \text { \& cols. sect. } \\
1 \text { under } \mathrm{f} 1.5\end{array}$ \\
\hline
\end{tabular}


Table B.1 - Cont.

\begin{tabular}{|c|c|c|c|c|}
\hline \multirow[b]{2}{*}{ Day } & \multicolumn{3}{|c|}{ Ambient Condition } & \multirow[b]{2}{*}{$\begin{array}{c}\text { Construction } \\
\text { Activity }\end{array}$} \\
\hline & $\begin{array}{l}\text { Low } \\
\text { Temp. } \\
\text { (F) }\end{array}$ & $\begin{array}{l}\text { High } \\
\text { Temp. } \\
\text { (F) }\end{array}$ & $\begin{array}{l}\text { Weather } \\
\text { Code }\end{array}$ & \\
\hline $5 / 29$ & 68 & 88 & s & $\begin{array}{l}\text { Framing sect. } 1 \text { fl. } 5 ; \text { place steel sect. } \\
4 \text { fl.4; strip sect. } 4 \text { fl. } 3 \text {; cast sect. } \\
3 \text { fl. } 4 \text { \& cols. sect. } 2 \text { under } 11.5\end{array}$ \\
\hline $5 / 30$ & 68 & 81 & S & $\begin{array}{l}\text { Framing sects. } 1,2 \mathrm{f} 1.5 \text {; strip misc. } \\
\text { on } \mathrm{f} 1.3 \text {; cast sect. } 4 \mathrm{f} 1.4 \text { \& cols. } \\
\text { sect. } 3 \text { under } \mathrm{f} 1.5\end{array}$ \\
\hline $6 / 2$ & 76 & 90 & S & $\begin{array}{l}\text { Framing sects. } 2,3 \mathrm{f} 1.5 ; \text { place stee } 1 \\
\text { sect. } 1 \mathrm{f} 1.5 \text {; strip sect. } 1 \mathrm{f} 1.4 \text {; cast } \\
\text { cols. sect } 4 \text { under } 11.5\end{array}$ \\
\hline $6 / 3$ & 79 & 91 & $S, C$ & $\begin{array}{l}\text { Framing sects. } 3 \text { \& } 4 \text { f } 1.5 ; \text { place stee } 1 \\
\text { sect. } 2 \text { fl.5; strip sect. } 2 \mathrm{f} 1.4 \text {; cast } \\
\text { sect. } 1 \text { f } 1.5\end{array}$ \\
\hline $6 / 4$ & 68 & 82 & S & $\begin{array}{l}\text { Framing sects. } 3,4 \mathrm{fl} .5 \text {; strip sects. } \\
3,4 \mathrm{fl} .4 ; \mathrm{place} \text { stee } 1 \text { sect. } 3 \mathrm{f} 1.5 ; \\
\text { cast sect. } 2 \mathrm{f} 1.5 \& \text { cols. sect. } 1 \text { under } \\
\text { fl.6 }\end{array}$ \\
\hline
\end{tabular}

Weather Code Notation :
C : Cloudy
$\mathrm{R}$ : Rain
$S$ : Sunny
W : Windy

SN: Snow 
Table B.2 Concrete cylinder test data

\begin{tabular}{|c|c|c|c|c|c|c|c|c|c|}
\hline \multirow{2}{*}{$\begin{array}{l}\text { Test } \\
\text { No. }\end{array}$} & \multirow{2}{*}{$\begin{array}{l}\text { Date \& } \\
\text { Time } \\
\text { Molded }\end{array}$} & \multirow{2}{*}{$\begin{array}{l}\text { Type } \\
\text { of } \\
\text { Mix }\end{array}$} & \multirow{2}{*}{$\begin{array}{l}\text { Conc. } \\
\text { Temp. } \\
\text { (F) }\end{array}$} & \multirow{2}{*}{$\begin{array}{l}\text { Air } \\
\text { Temp. } \\
\text { (F) }\end{array}$} & \multirow{2}{*}{$\begin{array}{l}\text { Slump } \\
\text { (in) }\end{array}$} & \multicolumn{3}{|c|}{$\begin{array}{c}\text { Cylinder Strength } \\
\text { (psi) }\end{array}$} & \multirow[b]{2}{*}{ Location } \\
\hline & & & & & & $5-d a y$ & 7-d ay & 28-day & \\
\hline 1 & $\begin{array}{r}2 / 26 \\
11: 55\end{array}$ & $A^{*}$ & 60 & 35 & $4-3 / 4$ & - & $\begin{array}{l}3320 \\
3420\end{array}$ & $\begin{array}{l}5440 \\
5280\end{array}$ & $\begin{array}{l}\text { Footings column } \\
\text { lines } A 10,11\end{array}$ \\
\hline 2 & $\begin{array}{l}2 / 27 \\
2: 20\end{array}$ & A & 68 & 40 & $3-3 / 4$ & - & $\begin{array}{l}3920 \\
4080\end{array}$ & $\begin{array}{l}5880 \\
5740\end{array}$ & Footing D9 \\
\hline 3 & $\begin{array}{l}3 / 4 \\
1: 40\end{array}$ & A & 60 & 42 & 4 & - & $\begin{array}{l}4120 \\
4140\end{array}$ & $\begin{array}{l}5860 \\
5660\end{array}$ & Footing $\mathrm{B} 10$ \\
\hline 4 & $\begin{array}{l}3 / 6 \\
2: 15\end{array}$ & A & 65 & 50 & 4 & - & $\begin{array}{l}3900 \\
3720\end{array}$ & $\begin{array}{l}4780 \\
4600\end{array}$ & Footing A6 \\
\hline 5 & $\begin{array}{l}3 / 7 \\
1: 35\end{array}$ & $\begin{array}{c}\text { At } \\
1 \% \text { cal. }\end{array}$ & 75 & 64 & 4 & - & $\begin{array}{l}4040 \\
3920\end{array}$ & $\begin{array}{l}5240 \\
5140\end{array}$ & $\begin{array}{l}\text { Footings G7, } \\
\text { H7-I7 }\end{array}$ \\
\hline 6 & $\begin{array}{l}3 / 10 \\
1: 15\end{array}$ & $C *$ & 72 & 62 & 4 & - & $\begin{array}{l}2800 \\
3000\end{array}$ & $\begin{array}{l}4240 \\
4420\end{array}$ & $\begin{array}{l}\text { W wall col. line } \\
10 \text { to C line S, } \\
\text { set } 1\end{array}$ \\
\hline 7 & $\begin{array}{l}3 / 10 \\
3: 30\end{array}$ & $B *$ & 74 & 63 & 5 & - & $\begin{array}{l}3140 \\
3040\end{array}$ & $\begin{array}{l}5060 \\
4960\end{array}$ & $\begin{array}{l}\text { Footings D5, D6, } \\
\text { D6A combination, } \\
\text { set } 2\end{array}$ \\
\hline 8 & $\begin{array}{l}3 / 11 \\
1: 10\end{array}$ & A & 65 & 35 & 3 & - & $\begin{array}{l}3640 \\
3540\end{array}$ & $\begin{array}{l}4600 \\
4720\end{array}$ & Footings $\mathrm{C} 1-\mathrm{C} 3$ \\
\hline 9 & $\begin{array}{l}3 / 12 \\
3: 05\end{array}$ & A & 67 & 34 & 4 & - & $\begin{array}{l}3720 \\
3580\end{array}$ & $\begin{array}{l}5560 \\
5500\end{array}$ & $\begin{array}{l}\text { Footings } \mathrm{F} 3, \mathrm{H} 3, \\
\text { I3 }\end{array}$ \\
\hline 10 & $\begin{array}{r}3 / 12 \\
12: 55\end{array}$ & A & 63 & 42 & 5 & - & $\begin{array}{l}3000 \\
2940\end{array}$ & $\begin{array}{l}4600 \\
4760\end{array}$ & $\begin{array}{l}\text { S wall between } \\
\mathrm{C} \& \mathrm{H} \text { lines }\end{array}$ \\
\hline 11 & $\begin{array}{l}3 / 18 \\
2: 20\end{array}$ & A & 69 & 46 & $3-1 / 2$ & - & $\begin{array}{l}3360 \\
3420\end{array}$ & $\begin{array}{l}5000 \\
4880\end{array}$ & $\begin{array}{l}\text { Footings } \mathrm{C} 4, \mathrm{D} 3, \\
\mathrm{D} 4 \text {, D4A, E5A, } \\
\mathrm{E} 6 \mathrm{~A} \text {, set } 2\end{array}$ \\
\hline 12 & $\begin{array}{l}3 / 19 \\
3: 30\end{array}$ & A & 70 & 66 & $4-3 / 4$ & - & $\begin{array}{l}3460 \\
3320\end{array}$ & $\begin{array}{l}5140 \\
5000\end{array}$ & $\begin{array}{l}\text { Footings C4a, } \\
\text { F2, G1, G2, H1, } \\
\text { H2, I1, Is }\end{array}$ \\
\hline 13 & $\begin{array}{l}3 / 20 \\
2: 25\end{array}$ & $\begin{array}{c}\mathrm{B}+ \\
4.2 \mathrm{Oz} \\
\mathrm{AEA}\end{array}$ & 72 & 56 & 4 & - & $\begin{array}{l}4180 \\
4240\end{array}$ & $\begin{array}{l}5960 \\
5820\end{array}$ & $\begin{array}{l}\text { W wall from col. } \\
\text { line } 10 \text { to } 6 \& \\
\text { SE wall from col } \\
\text { line G to } 9 \text { line }\end{array}$ \\
\hline 14 & $\begin{array}{l}3 / 25 \\
9: 40\end{array}$ & $\begin{array}{c}\mathrm{B}+ \\
4.2 \mathrm{oz} \\
\mathrm{AEA}\end{array}$ & 59 & 47 & 4 & - & $\begin{array}{l}4000 \\
4140\end{array}$ & $\begin{array}{l}5660 \\
5660\end{array}$ & $\begin{array}{l}\text { E wall between } 9 \\
\text { and } 2 \text { line, set } \\
1\end{array}$ \\
\hline
\end{tabular}


Table B.2 - Cont.

\begin{tabular}{|c|c|c|c|c|c|c|c|c|c|}
\hline \multirow{2}{*}{$\begin{array}{l}\text { Test } \\
\text { No. }\end{array}$} & \multirow{2}{*}{$\begin{array}{l}\text { Date \& } \\
\text { Time } \\
\text { Molded }\end{array}$} & \multirow{2}{*}{$\begin{array}{l}\text { Type } \\
\text { of } \\
\text { Mix }\end{array}$} & \multirow{2}{*}{$\begin{array}{l}\text { Conc. } \\
\text { Temp. } \\
\text { (F) }\end{array}$} & \multirow{2}{*}{$\begin{array}{l}\text { Air } \\
\text { Temp. } \\
\text { (F) }\end{array}$} & \multirow{2}{*}{$\begin{array}{l}\text { Slump } \\
\text { (in) }\end{array}$} & \multicolumn{3}{|c|}{$\begin{array}{c}\text { Cylinder Strength } \\
\text { (psi) }\end{array}$} & \multirow[b]{2}{*}{ Location } \\
\hline & & & & & & 5-day & 7-day & 28-day & \\
\hline 15 & $\begin{array}{r}3 / 25 \\
12: 05\end{array}$ & $\begin{array}{c}\mathrm{B}+ \\
11.2 \text { of } \\
\mathrm{AEA}\end{array}$ & 62 & 49 & 4 & - & $\begin{array}{l}3900 \\
4000\end{array}$ & $\begin{array}{l}5320 \\
5500\end{array}$ & Crane pad, set 2 \\
\hline 16 & $\begin{array}{l}3 / 26 \\
8: 30\end{array}$ & $\begin{array}{c}\mathrm{B}+ \\
4 \mathrm{oz} . \\
\mathrm{AEA}\end{array}$ & 56 & 42 & $4-1 / 2$ & - & $\begin{array}{l}4780 \\
4640\end{array}$ & $\begin{array}{l}5280 \\
5060\end{array}$ & $\begin{array}{l}\text { Sect. } 1 \text { SOG, } \\
\text { set } 1\end{array}$ \\
\hline 17 & $\begin{array}{r}3 / 26 \\
12: 20\end{array}$ & B & 58 & 47 & 3 & - & $\begin{array}{l}4460 \\
4600\end{array}$ & $\begin{array}{l}5740 \\
5920\end{array}$ & $\begin{array}{l}\text { Wall line } 3 \text { to } \\
\text { E wall, set } 2\end{array}$ \\
\hline 18 & $\begin{array}{l}3 / 27 \\
9: 25\end{array}$ & B & 62 & 48 & $5-1 / 2$ & - & $\begin{array}{l}4240 \\
4340\end{array}$ & $\begin{array}{l}5280 \\
5440\end{array}$ & $\begin{array}{l}\text { Sect. } 2 \text { SOG, } \\
\text { set } 1\end{array}$ \\
\hline 19 & $\begin{array}{l}3 / 27 \\
1: 45\end{array}$ & B & 62 & 58 & $4-3 / 4$ & - & $\begin{array}{l}3600 \\
3640\end{array}$ & $\begin{array}{l}4640 \\
4500\end{array}$ & $\begin{array}{l}\text { G line to } N E \\
\text { corner, set } 2\end{array}$ \\
\hline 20 & $\begin{array}{l}3 / 28 \\
9: 40\end{array}$ & B & 68 & 45 & $4-1 / 2$ & - & $\begin{array}{l}4280 \\
4180\end{array}$ & $\begin{array}{l}6040 \\
5880\end{array}$ & $\begin{array}{l}\text { Sect. } 3 \text { SOG, } \\
\text { set } 1\end{array}$ \\
\hline 21 & $\begin{array}{r}3 / 28 \\
10: 40\end{array}$ & B & 70 & 53 & 3 & - & $\begin{array}{l}4240 \\
4340\end{array}$ & $\begin{array}{l}6200 \\
6060\end{array}$ & $\begin{array}{l}\text { W wall } 1-3 \text {, } \\
\text { set } 2\end{array}$ \\
\hline 22 & $\begin{array}{l}4 / 1 \\
1: 40\end{array}$ & B & 62 & 70 & 4 & - & $\begin{array}{l}3080 \\
3360\end{array}$ & $\begin{array}{l}5060 \\
4940\end{array}$ & $\begin{array}{l}\text { W wall } 3-6 \mathrm{~N} \\
\text { A-D wall }\end{array}$ \\
\hline 23 & $\begin{array}{l}4 / 2 \\
3: 35\end{array}$ & A & 64 & 70 & 4 & - & $\begin{array}{l}3640 \\
3460\end{array}$ & $\begin{array}{l}5320 \\
5180\end{array}$ & $\begin{array}{l}\text { Co1s. C10, C11, } \\
\text { D10-D12, E10- } \\
\text { E12, F11, F12, } \\
\text { G11, G12 below } \\
\text { f1oor } 1\end{array}$ \\
\hline 24 & $\begin{array}{l}4 / 3 \\
9: 20\end{array}$ & B & 59 & 61 & 4 & - & $\begin{array}{l}3640 \\
3680\end{array}$ & $\begin{array}{l}5040 \\
5100\end{array}$ & $\begin{array}{l}\text { Sect } 4 \text { SOG, } \\
\text { set } 1\end{array}$ \\
\hline 25 & $\begin{array}{c}4 / 3 \\
12: 15\end{array}$ & B & 70 & 69 & 5 & - & $\begin{array}{l}3120 \\
3040\end{array}$ & $\begin{array}{l}4720 \\
4880\end{array}$ & $\begin{array}{l}\text { Cols. H11, H12, } \\
\text { I11, I12 below } \\
\text { floor } 1 \text {, set } 2\end{array}$ \\
\hline 26 & $\begin{array}{l}4 / 7 \\
9: 45\end{array}$ & $\begin{array}{c}\mathrm{B}+ \\
4 \mathrm{Oz} \\
\mathrm{AEA}\end{array}$ & 68 & 64 & 3 & - & $\begin{array}{l}3180 \\
3040\end{array}$ & $\begin{array}{l}4280 \\
4180\end{array}$ & $\begin{array}{l}\text { SOG sect. } 5 \text {, } \\
\text { set } 1\end{array}$ \\
\hline 27 & $\begin{array}{l}4 / 7 \\
2: 40\end{array}$ & A & 62 & 72 & 5 & - & $\begin{array}{l}3400 \\
3260\end{array}$ & $\begin{array}{l}4940 \\
5100\end{array}$ & $\begin{array}{l}\text { First floor cols } \\
\text { C8, C9, C12, E9, } \\
\text { F9, F10, G9, G10 } \\
\text { H9, H10, I9, I10 } \\
\text { set } 2\end{array}$ \\
\hline
\end{tabular}


Table B.2 - Cont.

\begin{tabular}{|c|c|c|c|c|c|c|c|c|c|}
\hline \multirow{2}{*}{$\begin{array}{l}\text { Test } \\
\text { No. }\end{array}$} & \multirow{2}{*}{$\begin{array}{l}\text { Date \& } \\
\text { Time } \\
\text { Molded }\end{array}$} & \multirow{2}{*}{$\begin{array}{l}\text { Type } \\
\text { of } \\
\text { Mix }\end{array}$} & \multirow{2}{*}{$\begin{array}{l}\text { Conc. } \\
\text { Temp. } \\
\text { (F) }\end{array}$} & \multirow{2}{*}{$\begin{array}{l}\text { Air } \\
\text { Temp } \\
\text { (F) }\end{array}$} & \multirow{2}{*}{$\begin{array}{l}\text { Slump } \\
\text { (in) }\end{array}$} & \multicolumn{3}{|c|}{$\begin{array}{c}\text { Cylinder Strength } \\
\text { (psi) }\end{array}$} & \multirow[b]{2}{*}{ Location } \\
\hline & & & & & & 5-day & 7-day & 28-day & \\
\hline 28 & $\begin{array}{l}4 / 8 \\
8: 55\end{array}$ & $\begin{array}{l}\mathrm{B}+ \\
4 \mathrm{Oz} \\
\mathrm{AEA}\end{array}$ & 68 & 60 & 5 & - & $\begin{array}{l}3000 \\
3080\end{array}$ & $\begin{array}{l}4380 \\
4420\end{array}$ & $\begin{array}{l}\text { Sect. } 6 \text { SOG, } \\
\text { set } 1\end{array}$ \\
\hline 29 & $\begin{array}{c}4 / 8 \\
11: 15\end{array}$ & $\begin{array}{l}\mathrm{B}+ \\
4 \mathrm{Oz} \\
\mathrm{AEA}\end{array}$ & 70 & 72 & $3-1 / 2$ & - & $\begin{array}{l}3420 \\
3460\end{array}$ & $\begin{array}{l}5440 \\
5240\end{array}$ & $\begin{array}{l}\text { Co]s. C9, D8, E8, } \\
\text { F8, I10, set } 2\end{array}$ \\
\hline 30 & $\begin{array}{l}4 / 10 \\
9: 10\end{array}$ & $\begin{array}{l}\mathrm{B}+ \\
4 \mathrm{Oz} \\
\mathrm{AEA}\end{array}$ & 66 & 60 & $3-1 / 2$ & - & $\begin{array}{l}2980 \\
2940\end{array}$ & $\begin{array}{l}3900 \\
3960\end{array}$ & $\begin{array}{l}\text { Sect. } 7 \text { SOG, } \\
\text { set } 1\end{array}$ \\
\hline 31 & $\begin{array}{l}4 / 10 \\
2: 45\end{array}$ & $\mathrm{~A}$ & 73 & 68 & $3-3 / 4$ & - & $\begin{array}{l}3580 \\
3500\end{array}$ & $\begin{array}{l}4540 \\
4820\end{array}$ & $\begin{array}{l}\text { Cols. B6, B7, C7, } \\
\text { D7, E7, F6, F7, } \\
\text { G6-G8, H6, H7 } \\
\text { below floor 1, } \\
\text { set } 2\end{array}$ \\
\hline 32 & $\begin{array}{l}4 / 11 \\
9: 25\end{array}$ & B & 61 & 60 & 4 & - & $\begin{array}{l}3360 \\
3280\end{array}$ & $\begin{array}{l}4780 \\
4540\end{array}$ & $\begin{array}{l}\text { Sect. } 2 \text { floor } 1 \text {, } \\
\text { set } 1\end{array}$ \\
\hline 33 & $\begin{array}{r}4 / 11 \\
11: 30\end{array}$ & B & 67 & 70 & 4 & - & $\begin{array}{l}3360 \\
3420\end{array}$ & $\begin{array}{l}4960 \\
4780\end{array}$ & $\begin{array}{l}\text { Cols. B5, C6, C6a } \\
\text { C6b, C7a, Da, E5a } \\
\text { E6, E6a, I4-I7, } \\
\text { set } 2\end{array}$ \\
\hline 34 & $\begin{array}{l}4 / 15 \\
9: 25\end{array}$ & $\begin{array}{l}\mathrm{B}+ \\
\mathrm{OZ} \\
\mathrm{AEA}\end{array}$ & 64 & 50 & $3-1 / 2$ & - & $\begin{array}{l}3900 \\
4140\end{array}$ & $\begin{array}{l}5040 \\
4940\end{array}$ & $\begin{array}{l}\text { Sect. } 8 \text { SOG, } \\
\text { set } 1\end{array}$ \\
\hline 35 & $\begin{array}{r}4 / 15 \\
12: 30\end{array}$ & B & 62 & 53 & 4 & - & $\begin{array}{l}3420 \\
3280\end{array}$ & $\begin{array}{l}4640 \\
4500\end{array}$ & $\begin{array}{l}\text { Cols. B4, C4-D4A, } \\
\text { C4, C5A, D5, E5A, } \\
\text { E6A, F5, G5, H5, } \\
\text { set } 2\end{array}$ \\
\hline 36 & $\begin{array}{l}4 / 16 \\
8: 30\end{array}$ & $\begin{array}{l}\mathrm{B}+ \\
4 \mathrm{OZ} \\
\mathrm{AEA}\end{array}$ & 57 & 50 & 4 & - & $\begin{array}{l}3580 \\
3580\end{array}$ & $\begin{array}{l}4540 \\
4420\end{array}$ & $\begin{array}{l}\text { Sect. } 1 \text { floor } 1 \text {, } \\
\text { set } 1\end{array}$ \\
\hline 37 & $\begin{array}{r}4 / 16 \\
12: 35\end{array}$ & $\begin{array}{l}\mathrm{B}+ \\
4 \mathrm{Oz} \\
\mathrm{AEA}\end{array}$ & 62 & 50 & 4 & - & $\begin{array}{l}3180 \\
3260\end{array}$ & $\begin{array}{l}4640 \\
4500\end{array}$ & $\begin{array}{l}\text { Cols. B2, B3, C2, } \\
\text { C3, D2, D3, E2, } \\
\text { E3, F3, G3, G4, } \\
\text { H3, set } 2\end{array}$ \\
\hline 38 & $\begin{array}{l}4 / 17 \\
8: 20\end{array}$ & B & 62 & 59 & 4 & $\begin{array}{l}2860 \\
2760\end{array}$ & $\begin{array}{l}3000 \\
3080\end{array}$ & $\begin{array}{l}4600 \\
4500\end{array}$ & $\begin{array}{l}\text { Sect. } 3 \text { floor } 1 \text {, } \\
\text { set } 1\end{array}$ \\
\hline
\end{tabular}


Table B.2 - Cont.

\begin{tabular}{|c|c|c|c|c|c|c|c|c|c|}
\hline \multirow{2}{*}{$\begin{array}{l}\text { Test } \\
\text { No. }\end{array}$} & \multirow{2}{*}{$\begin{array}{l}\text { Date \& } \\
\text { Time } \\
\text { Molded }\end{array}$} & \multirow{2}{*}{$\begin{array}{l}\text { Type } \\
\text { of } \\
\text { Mix }\end{array}$} & \multirow{2}{*}{$\begin{array}{l}\text { Conc. } \\
\text { Temp. } \\
\text { (F) }\end{array}$} & \multirow{2}{*}{$\begin{array}{l}\text { Air } \\
\text { Temp. } \\
\text { (F) }\end{array}$} & \multirow{2}{*}{$\begin{array}{l}\text { Slump } \\
\text { (in) }\end{array}$} & \multicolumn{3}{|c|}{$\begin{array}{c}\text { Cylinder Strength } \\
\text { (psi) }\end{array}$} & \multirow[b]{2}{*}{ Location } \\
\hline & & & & & & 5-day & 7-day & 28-day & \\
\hline 39 & $\begin{array}{l}4 / 17 \\
3: 50\end{array}$ & A & 66 & 60 & $3-3 / 4$ & - & $\begin{array}{l}3260 \\
3120\end{array}$ & $\begin{array}{l}4680 \\
4820\end{array}$ & $\begin{array}{l}\text { Cols. B1, C1, D1, } \\
\mathrm{E} 1, \mathrm{~F} 1, \mathrm{~F} 2, \mathrm{G} 2, \\
\mathrm{H} 2, \text { set } 2\end{array}$ \\
\hline 40 & $\begin{array}{l}4 / 18 \\
1: 20\end{array}$ & A & 64 & 70 & 4 & - & $\begin{array}{l}3260 \\
3360\end{array}$ & $\begin{array}{l}5280 \\
5180\end{array}$ & $\left|\begin{array}{l}\text { Cols. B8, B9, C9, } \\
\text { D9, E9, story } 1\end{array}\right|$ \\
\hline 41 & $\begin{array}{l}4 / 21 \\
8: 25\end{array}$ & B & 64 & 64 & 4 & $\begin{array}{l}2720 \\
2840\end{array}$ & $\begin{array}{l}3280 \\
3140\end{array}$ & $\begin{array}{l}4240 \\
4080\end{array}$ & $\begin{array}{l}\text { Sect. } 4 \text { floor } 1 \text {, } \\
\text { set } 1\end{array}$ \\
\hline 42 & $\begin{array}{r}4 / 21 \\
12: 55\end{array}$ & $\begin{array}{l}\mathrm{B}+ \\
4 \mathrm{O} z \\
\mathrm{AEA}\end{array}$ & 70 & 69 & 4 & - & $\begin{array}{l}2900 \\
2840\end{array}$ & $\begin{array}{l}3720 \\
3580\end{array}$ & $\begin{array}{l}\text { F1oor } 1 \text { cols. I0, } \\
\text { I1, I2, I3, H1; } \\
\text { F1oor } 2 \text { cols. C8, } \\
\text { D8, E8, set } 2\end{array}$ \\
\hline 43 & $\begin{array}{l}4 / 22 \\
8: 15\end{array}$ & A & 66 & 64 & 4 & $\begin{array}{l}2440 * \\
2720 *\end{array}$ & $\begin{array}{l}3180 \\
3120\end{array}$ & $\begin{array}{l}3680 \\
3960\end{array}$ & $\begin{array}{l}\text { Sect. } 5 \text { floor } 1 \text {, } \\
\text { set } 1\end{array}$ \\
\hline 44 & $\begin{array}{r}4 / 22 \\
12: 40\end{array}$ & A & 72 & 74 & 4 & - & $\begin{array}{l}3120 \\
3180\end{array}$ & $\begin{array}{l}4000 \\
4120\end{array}$ & $\begin{array}{l}\text { Cols. F8, F9, } \\
\text { set } 2\end{array}$ \\
\hline 45 & $\begin{array}{l}4 / 23 \\
8: 45\end{array}$ & $\begin{array}{c}\mathrm{B}+ \\
4 \mathrm{oz}\end{array}$ & 66 & 73 & $4-3 / 4$ & $\begin{array}{l}2400 \\
2680\end{array}$ & $\begin{array}{l}3000 \\
2940\end{array}$ & $\begin{array}{l}3780 \\
3900\end{array}$ & $\begin{array}{l}\text { Sect. } 6 \text { floor } 1 \text {, } \\
\text { set } 1\end{array}$ \\
\hline 46 & $\begin{array}{r}4 / 23 \\
12: 10\end{array}$ & $\begin{array}{l}\mathrm{B}+ \\
4 \mathrm{oz} \\
\mathrm{AEA}\end{array}$ & 70 & 76 & 4 & - & $\begin{array}{l}3000 \\
3000\end{array}$ & $\begin{array}{l}4120 \\
4000\end{array}$ & $\begin{array}{l}\text { Cols, } 7 B, 7 C, 7 D \\
7 E, 6 E, \text { set } 2\end{array}$ \\
\hline 47 & $\begin{array}{l}4 / 24 \\
9: 10\end{array}$ & A & 70 & 66 & $4-1 / 2$ & $\begin{array}{l}2400 \\
2440\end{array}$ & $\begin{array}{l}2840 \\
2800\end{array}$ & $\begin{array}{l}3920 \\
4200\end{array}$ & $\begin{array}{l}\text { Sect. } 7 \text { floor } 1 \text {, } \\
\text { set } 1\end{array}$ \\
\hline 48 & $\begin{array}{r}4 / 24 \\
12: 15\end{array}$ & A & 72 & 78 & 4 & - & $\begin{array}{l}3000 \\
2980\end{array}$ & $\begin{array}{l}4340 \\
4600\end{array}$ & $\begin{array}{l}\text { Co1s. D6A, C7A, } \\
\text { E6, E7, set } 2\end{array}$ \\
\hline 49 & $\begin{array}{l}4 / 25 \\
8: 57\end{array}$ & $\begin{array}{l}\mathrm{B}+ \\
4 \mathrm{Oz} \\
\mathrm{AEA}\end{array}$ & 70 & 67 & 4 & $\begin{array}{l}2120 \\
2160\end{array}$ & $\begin{array}{l}2620 \\
2480\end{array}$ & $\begin{array}{l}3720 \\
3680\end{array}$ & $\begin{array}{l}\text { Sect. } 8 \text { floor } 1 \text {, } \\
\text { set } 1\end{array}$ \\
\hline 50 & $\begin{array}{r}4 / 25 \\
12: 40\end{array}$ & A & 72 & 69 & 4 & - & $\begin{array}{l}3180 \\
3120\end{array}$ & $\begin{array}{l}4540 \\
4380\end{array}$ & $\begin{array}{l}\text { F1oor } 2 \text { cols. B4, } \\
\mathrm{C} 4, \mathrm{C} 4 \mathrm{~A}, \mathrm{C} 5 \mathrm{~A}, \mathrm{D} 3, \\
\mathrm{D} 4, \mathrm{D} 4 \mathrm{~A}, \mathrm{E} 4, \mathrm{E} 5, \\
\text { set } 2\end{array}$ \\
\hline 51 & $\begin{array}{r}4 / 28 \\
11: 40\end{array}$ & A & 62 & 58 & 4 & - & $\begin{array}{l}3180 \\
3180\end{array}$ & $\begin{array}{l}5240 \\
5320\end{array}$ & $\begin{array}{l}\text { Cols. A10, B10, } \\
\text { C10, E10, F4, F5, } \\
\text { E5A below floor } 2\end{array}$ \\
\hline
\end{tabular}


Table B.2 - Cont.

\begin{tabular}{|c|c|c|c|c|c|c|c|c|c|}
\hline \multirow{2}{*}{$\begin{array}{l}\text { Test } \\
\text { No. }\end{array}$} & \multirow{2}{*}{$\begin{array}{l}\text { Date } \& \\
\text { Time } \\
\text { Molded }\end{array}$} & \multirow{2}{*}{$\begin{array}{l}\text { Type } \\
\text { of } \\
\text { Mix }\end{array}$} & \multirow{2}{*}{$\begin{array}{l}\text { Conc. } \\
\text { Temp. } \\
\text { (F) }\end{array}$} & \multirow{2}{*}{$\begin{array}{l}\text { Air } \\
\text { Temp } \\
\text { (F) }\end{array}$} & \multirow{2}{*}{$\begin{array}{l}\text { Slump } \\
\text { (in) }\end{array}$} & \multicolumn{3}{|c|}{$\begin{array}{c}\text { Cylinder Strength } \\
\text { (psi) }\end{array}$} & \multirow[b]{2}{*}{ Location } \\
\hline & & & & & & 5-day & 7-day & 28-day & \\
\hline 52 & $\begin{array}{l}4 / 29 \\
9: 45\end{array}$ & $\begin{array}{l}\text { B+ } \\
4 \mathrm{Oz} \\
\mathrm{AEA}\end{array}$ & 64 & 54 & $4-1 / 2$ & $\begin{array}{l}2500 * \\
2380 *\end{array}$ & $\begin{array}{l}3040 \\
2980\end{array}$ & $\begin{array}{l}4720 \\
4640\end{array}$ & $\begin{array}{l}\text { Sect. } 9 \text { floor } 1 \text {, } \\
\text { set } 1\end{array}$ \\
\hline 53 & $\begin{array}{l}4 / 29 \\
3: 10\end{array}$ & A & 64 & 67 & $3-1 / 2$ & - & $\begin{array}{l}2720 \\
2840\end{array}$ & $\begin{array}{l}4880 \\
4960\end{array}$ & $\begin{array}{l}\text { Cols. A9, E10, } \\
\text { F10, G10 below } \\
\text { f1oor } 2 \text {, set } 2\end{array}$ \\
\hline 54 & $\begin{array}{r}4 / 30 \\
12: 30\end{array}$ & $\mathrm{~A}$ & 65 & 63 & 4 & - & $\begin{array}{l}3420 \\
3320\end{array}$ & $\begin{array}{l}4560 \\
4760\end{array}$ & $\begin{array}{l}\text { Cols. A8, B3, C2, } \\
\text { C3, D3, E3, G7, } \\
\text { G8, G9 below } \\
\text { f1oor } 2\end{array}$ \\
\hline 55 & $\begin{array}{c}5 / 1 \\
12: 10\end{array}$ & $A$ & 70 & 68 & 4 & - & $\begin{array}{l}3180 \\
3360\end{array}$ & $\begin{array}{l}4760 \\
4780\end{array}$ & $\begin{array}{l}\text { Cols. A7, G4-G6 } \\
\text { below f1oor } 2\end{array}$ \\
\hline 56 & $\begin{array}{l}5 / 2 \\
9: 00\end{array}$ & $\begin{array}{l}\mathrm{B}+ \\
4 \mathrm{Oz} \\
\mathrm{AEA}\end{array}$ & 70 & 69 & $4-1 / 2$ & $\begin{array}{l}2840 \\
2760\end{array}$ & 2900 & $\begin{array}{l}4540 \\
4280\end{array}$ & $\begin{array}{l}\text { Sect. } 10 \text { floor } 1 \\
\text { set } 1\end{array}$ \\
\hline 57 & $\begin{array}{c}5 / 2 \\
12: 15\end{array}$ & $\begin{array}{l}\mathrm{B}+ \\
4 \mathrm{Oz} \\
\mathrm{AEA}\end{array}$ & 72 & 77 & 4 & $\begin{array}{l}3400 \\
3580\end{array}$ & $\begin{array}{l}3640 \\
3580\end{array}$ & $\begin{array}{l}4780 \\
4960\end{array}$ & $\begin{array}{l}\text { Sect. } 10 \text { floor } 1, \\
\text { set } 2\end{array}$ \\
\hline 58 & $\begin{array}{l}5 / 2 \\
2: 15\end{array}$ & $\begin{array}{l}\mathrm{B}+ \\
4 \mathrm{Oz} \\
\mathrm{AEA}\end{array}$ & 72 & 76 & 4 & - & $\begin{array}{l}3220 \\
3040\end{array}$ & $\begin{array}{l}4280 \\
4280\end{array}$ & $\begin{array}{l}\text { Co1s. A6, B2, B6, } \\
\text { C5, C6, D2, E2 } \\
\text { below f1oor 2, } \\
\text { set } 3\end{array}$ \\
\hline 59 & $\begin{array}{l}5 / 5 \\
9: 00\end{array}$ & $\begin{array}{l}\mathrm{B}+ \\
4 \mathrm{Oz} \\
\mathrm{AEA}\end{array}$ & 71 & 75 & 4 & $\begin{array}{l}2580 \\
2580\end{array}$ & $\begin{array}{l}2900 \\
2980\end{array}$ & $\begin{array}{l}4200 \\
4200\end{array}$ & $\begin{array}{l}\text { Sect. } 1 \text { floor 2, } \\
\text { set } 1\end{array}$ \\
\hline 60 & $\begin{array}{l}5 / 5 \\
1: 00\end{array}$ & $\begin{array}{l}\mathrm{B}+ \\
4 \mathrm{Oz} \\
\mathrm{AEA}\end{array}$ & 77 & 86 & 4 & - & $\begin{array}{l}2980 \\
2860\end{array}$ & $\begin{array}{l}4240 \\
4120\end{array}$ & $\begin{array}{l}\text { Co1s. A3-A5, B5, } \\
\text { F2, F3, set } 2\end{array}$ \\
\hline 61 & $\begin{array}{l}5 / 6 \\
1: 15\end{array}$ & $\mathrm{~A}$ & 78 & 84 & 5 & - & $\begin{array}{l}3080 \\
3000\end{array}$ & $\begin{array}{l}4640 \\
4540\end{array}$ & $\begin{array}{l}\text { Cols. C1, D1, G2, } \\
\mathrm{G} 3 \text { to f1oor 2; } \\
\text { cols. A10, B10, } \\
\mathrm{C} 10, \mathrm{D} 10, \mathrm{E} 10, \\
\mathrm{~F} 10, \mathrm{G} 10, \mathrm{~F} 8, \mathrm{~F} 9 \\
\text { to floor } 3\end{array}$ \\
\hline 62 & $\begin{array}{l}5 / 7 \\
8: 50\end{array}$ & $A$ & 75 & 77 & $3-3 / 4$ & $\begin{array}{l}2580 \\
2500\end{array}$ & $\begin{array}{l}3360 \\
3500\end{array}$ & $\begin{array}{l}4640 \\
4500\end{array}$ & $\begin{array}{l}\text { Sect. } 3 \text { floor } 2, \\
\text { set } 1\end{array}$ \\
\hline
\end{tabular}


Table B.2 - Cont.

\begin{tabular}{|c|c|c|c|c|c|c|c|c|c|}
\hline \multirow{2}{*}{$\begin{array}{l}\text { Test } \\
\text { No. }\end{array}$} & \multirow{2}{*}{$\begin{array}{l}\text { Date \& } \\
\text { Time } \\
\text { Molded }\end{array}$} & \multirow{2}{*}{$\begin{array}{l}\text { Type } \\
\text { of } \\
\text { Mix }\end{array}$} & \multirow{2}{*}{$\begin{array}{l}\text { Conc. } \\
\text { Temp. } \\
\text { (F) }\end{array}$} & \multirow{2}{*}{$\begin{array}{l}\text { Air } \\
\text { Temp. } \\
\text { (F) }\end{array}$} & \multirow{2}{*}{$\begin{array}{l}\text { Slump } \\
\text { (in) }\end{array}$} & \multicolumn{3}{|c|}{$\begin{array}{c}\text { Cylinder Strength } \\
\text { (psi) }\end{array}$} & \multirow[b]{2}{*}{ Location } \\
\hline & & & & & & 5-day & 7-day & 28-day & \\
\hline 63 & $\begin{array}{l}5 / 7 \\
1: 30\end{array}$ & A & 78 & 81 & $4-1 / 2$ & - & $\begin{array}{l}3360 \\
3320\end{array}$ & $\begin{array}{l}5320 \\
5100\end{array}$ & $\begin{array}{l}\text { Cols. B1, E1, F1, } \\
\text { G1 to floor 2; } \\
\text { cols. A8, A9, B8, } \\
\text { B9, C8, C9, D8, } \\
\text { E8, F8, G8, G9 to } \\
\text { floor } 3 \text {, set } 2\end{array}$ \\
\hline 64 & $\begin{array}{l}5 / 8 \\
11: 00\end{array}$ & A & 70 & 65 & 4 & - & $\begin{array}{l}3680 \\
3600\end{array}$ & $\begin{array}{l}5140 \\
4960\end{array}$ & $\begin{array}{l}\text { Cols. A1-A2 to } \\
\text { floor } 2\end{array}$ \\
\hline 65 & $\begin{array}{l}5 / 9 \\
9: 25\end{array}$ & A & 64 & 62 & 4 & $\begin{array}{l}2720 \\
3000\end{array}$ & $\begin{array}{l}3420 \\
3360\end{array}$ & $\begin{array}{l}4420 \\
4280\end{array}$ & $\begin{array}{l}\text { Sect. } 3 \text { floor 2, } \\
\text { set } 1\end{array}$ \\
\hline 66 & $\begin{array}{c}5 / 9 \\
12: 00\end{array}$ & $\begin{array}{c}\text { At } \\
1=2 \% \\
\text { cal }\end{array}$ & 67 & 68 & 5 & - & $\begin{array}{l}3400 \\
3400\end{array}$ & $\begin{array}{l}4820 \\
4720\end{array}$ & $\begin{array}{l}\text { Cols, below floon } \\
3 \text {, set } 2\end{array}$ \\
\hline 67 & $\begin{array}{l}5 / 12 \\
8: 15\end{array}$ & A & 73 & 75 & 5 & $\begin{array}{l}2660 \\
2680\end{array}$ & $\begin{array}{l}2840 \\
2800\end{array}$ & $\begin{array}{l}3720 \\
3640\end{array}$ & $\begin{array}{l}\text { Sect. } 4 \text { floor 2, } \\
\text { set } 1\end{array}$ \\
\hline 68 & $\begin{array}{r}5 / 12 \\
12: 20\end{array}$ & A & 80 & 85 & 5 & - & $\begin{array}{l}2660 \\
2660\end{array}$ & $\begin{array}{l}3860 \\
3820\end{array}$ & $\begin{array}{l}\text { Cols. below floor } \\
3 \text { sect. } 3 \text {, set } 2\end{array}$ \\
\hline 69 & $\begin{array}{l}5 / 13 \\
1: 45\end{array}$ & A & 85 & 85 & 4 & - & $\begin{array}{l}3120 \\
3120\end{array}$ & $\begin{array}{l}4240 \\
4080\end{array}$ & $\begin{array}{l}\text { Cols. below floor } \\
3\end{array}$ \\
\hline 70 & $\begin{array}{l}5 / 14 \\
8: 10\end{array}$ & A & 81 & 75 & 5 & $\begin{array}{l}2200 \\
2260\end{array}$ & $\begin{array}{l}2540 \\
2680\end{array}$ & $\begin{array}{l}4640 \\
4500\end{array}$ & Sect. 1 floor 3 \\
\hline 71 & $\begin{array}{l}5 / 15 \\
1: 00\end{array}$ & A & 70 & 76 & 5 & - & $\begin{array}{l}3420 \\
3320\end{array}$ & $\begin{array}{l}5240 \\
5100\end{array}$ & $\begin{array}{l}\text { Cols. below floor } \\
4 \text { sect. } 1\end{array}$ \\
\hline 72 & $\begin{array}{l}5 / 16 \\
9: 35\end{array}$ & A & 73 & 70 & 4 & $\begin{array}{l}2980 \\
2800\end{array}$ & $\begin{array}{l}3320 \\
3400\end{array}$ & $\begin{array}{l}5320 \\
5180\end{array}$ & Sect. 2 floor 3 \\
\hline 73 & $\begin{array}{l}5 / 19 \\
7: 45\end{array}$ & A & 70 & 58 & $4-3 / 4$ & $\begin{array}{l}2620 \\
2680\end{array}$ & $\begin{array}{l}3360 \\
3460\end{array}$ & $\begin{array}{l}4880 \\
5100\end{array}$ & $\begin{array}{l}\text { Sect. } 3 \text { floor } 3 \text {, } \\
\text { set } 1\end{array}$ \\
\hline 74 & $\begin{array}{l}5 / 19 \\
1: 30\end{array}$ & A & 79 & 77 & $4-1 / 2$ & - & $\begin{array}{l}3360 \\
3360\end{array}$ & $\begin{array}{l}4600 \\
4680\end{array}$ & $\begin{array}{l}\text { Cols. below floor } \\
4 \text { sect. } 2 \text {, set } 2\end{array}$ \\
\hline 75 & $\begin{array}{l}5 / 22 \\
8: 15\end{array}$ & A & 74 & 75 & 4 & $\begin{array}{l}2620 \\
2620\end{array}$ & $\begin{array}{l}2720 \\
2660\end{array}$ & $\begin{array}{l}4240 \\
4080\end{array}$ & $\begin{array}{l}\text { Sect. } 4 \text { floor } 3 \text {, } \\
\text { set } 1\end{array}$ \\
\hline 76 & $\begin{array}{r}5 / 22 \\
11: 35\end{array}$ & A & 74 & 76 & $4-1 / 4$ & - & $\begin{array}{l}3000 \\
2940\end{array}$ & $\begin{array}{l}4140 \\
4200\end{array}$ & $\begin{array}{l}\text { Cols. below floon } \\
4 \text { sect. } 3 \text {, set } 2\end{array}$ \\
\hline 77 & $\begin{array}{r}5 / 23 \\
12: 10\end{array}$ & A & 77 & 75 & 4 & - & $\begin{array}{l}2760 \\
2760\end{array}$ & $\begin{array}{l}4080 \\
4120\end{array}$ & $\begin{array}{l}\text { Cols. to floor } 4 \\
\text { sect. } 4\end{array}$ \\
\hline
\end{tabular}


Table B.2 - Cont.

\begin{tabular}{|c|c|c|c|c|c|c|c|c|c|}
\hline \multirow{2}{*}{$\begin{array}{l}\text { Test } \\
\text { No. }\end{array}$} & \multirow{2}{*}{$\begin{array}{l}\text { Date \& } \\
\text { Time } \\
\text { Molded }\end{array}$} & \multirow{2}{*}{$\begin{array}{l}\text { Type } \\
\text { of } \\
\text { Mix }\end{array}$} & \multirow{2}{*}{$\begin{array}{l}\text { Conc. } \\
\text { Temp. } \\
\text { (F) }\end{array}$} & \multirow{2}{*}{$\begin{array}{l}\text { Air } \\
\text { Temp. } \\
\text { (F) }\end{array}$} & \multirow{2}{*}{$\begin{array}{l}\text { Slump } \\
\text { (in) }\end{array}$} & \multicolumn{3}{|c|}{$\begin{array}{c}\text { Cylinder Strength } \\
\text { (psi) }\end{array}$} & \multirow[b]{2}{*}{ Location } \\
\hline & & & & & & $5-$ day & 7-day & 28-day & \\
\hline 78 & $\begin{array}{l}5 / 27 \\
9: 15\end{array}$ & A & 71 & 65 & 5 & $\begin{array}{l}2660 * \\
2720 *\end{array}$ & $\begin{array}{l}2840 \\
2900\end{array}$ & $\begin{array}{l}4140 \\
4320\end{array}$ & Sect, 1 floor 4 \\
\hline 79 & $\begin{array}{l}5 / 28 \\
9: 15\end{array}$ & A & 75 & 68 & $5-1 / 4$ & $\begin{array}{l}2720 \\
2620\end{array}$ & $\begin{array}{l}3080 \\
3000\end{array}$ & $\begin{array}{l}4540 \\
4380\end{array}$ & $\begin{array}{l}\text { Sect. } 2 \text { floor } 4, \\
\text { set } 1\end{array}$ \\
\hline 80 & $\begin{array}{r}5 / 28 \\
11: 20\end{array}$ & A & 76 & 80 & 5 & - & $\begin{array}{l}3280 \\
3400\end{array}$ & $\begin{array}{l}4780 \\
4600\end{array}$ & $\left|\begin{array}{l}\text { Cols. to floor } 5 \\
\text { sect. } 1 \text {, set } 2\end{array}\right|$ \\
\hline 81 & $\begin{array}{l}5 / 29 \\
9: 00\end{array}$ & A & 76 & 78 & 5 & $\begin{array}{l}2940 \\
2900\end{array}$ & $\begin{array}{l}3120 \\
3120\end{array}$ & $\begin{array}{l}4600 \\
4540\end{array}$ & $\begin{array}{l}\text { Sect. } 3 \text { floor } 4, \\
\text { set } 1\end{array}$ \\
\hline 82 & $\begin{array}{l}5 / 29 \\
2: 25\end{array}$ & A & 77 & 79 & 4 & - & $\begin{array}{l}3140 \\
3180\end{array}$ & $\begin{array}{l}4120 \\
4180\end{array}$ & $\begin{array}{l}\text { Cols. below floor } \\
5 \text { sect. } 2 \text {, set } 2\end{array}$ \\
\hline 83 & $\begin{array}{r}5 / 30 \\
10: 00\end{array}$ & A & 80 & 76 & 5 & $\begin{array}{l}3000 \\
3040\end{array}$ & $\begin{array}{l}3400 \\
3180\end{array}$ & $\begin{array}{l}4420 \\
4640\end{array}$ & $\begin{array}{l}\text { Sect. } 4 \text { floor } 4, \\
\text { set } 1\end{array}$ \\
\hline 84 & $\begin{array}{r}5 / 30 \\
12: 15\end{array}$ & A & 80 & 82 & 4 & - & $\begin{array}{l}3220 \\
3360\end{array}$ & $\begin{array}{l}4780 \\
4600\end{array}$ & $\begin{array}{l}\text { Cols. below floor } \\
5 \text { sect. } 3 \text {, set } 2\end{array}$ \\
\hline 85 & $\begin{array}{l}6 / 2 \\
1: 00\end{array}$ & A & 83 & 87 & $4-1 / 2$ & - & $\begin{array}{l}3600 \\
3540\end{array}$ & $\begin{array}{l}5000 \\
4860\end{array}$ & $\begin{array}{l}\text { Cols. below floor } \\
5 \text { sect. } 4\end{array}$ \\
\hline 86 & $\begin{array}{l}6 / 3 \\
8: 20\end{array}$ & A & 78 & 76 & $4-1 / 2$ & $\begin{array}{l}2760 * \\
2840 *\end{array}$ & $\begin{array}{l}3040 \\
3000\end{array}$ & $\begin{array}{l}4420 \\
4280\end{array}$ & Sect. 1 floor 5 \\
\hline 87 & $\begin{array}{l}6 / 4 \\
8: 20\end{array}$ & A & 78 & 75 & 4 & $\begin{array}{l}2660 \\
2660\end{array}$ & $\begin{array}{l}3080 \\
3000\end{array}$ & $\begin{array}{l}4640 \\
4500\end{array}$ & $\begin{array}{l}\text { Sect. } 2 \text { floor } 5, \\
\text { set } 1\end{array}$ \\
\hline 88 & $\begin{array}{c}6 / 4 \\
12: 00\end{array}$ & A & 77 & 79 & 7 & - & $\begin{array}{l}3080 \\
2860\end{array}$ & $\begin{array}{l}4540 \\
4780\end{array}$ & $\begin{array}{l}\text { Cols. below floor } \\
6 \text { sect. } 1 \text {, set } 2\end{array}$ \\
\hline
\end{tabular}

Field cured and tested at six days

Note: $6^{\prime \prime} \times 12^{\prime \prime}\left(28.27 \mathrm{in}^{2}\right)$ cylinders molded in accordance with ASTM C-31 and tested in accordance with ASTM C-39.

Mix types (by weight):

\begin{tabular}{|l||c|c|c|}
\hline Type & A & B & C \\
\hline \hline Cement & 564 & 564 & 564 \\
\hline Fine Aggr. & 1170 & 1070 & 1070 \\
\hline Coarse Aggr. & 1970 & 1970 & 1920 \\
\hline
\end{tabular}

UNITS:

1 in $=25.4 \mathrm{~mm}$

$1 \mathrm{psi}=6.9 \mathrm{kPa}$

${ }^{\circ} \mathrm{C}=(5 / 9)\left({ }^{\circ} \mathrm{F}-32\right)$

$1 \mathrm{oz}=28.3 \mathrm{~g}$ 
APPENDIX C

Selected Data on

Shoring Systems 
Complete shoring towers have been tested both at testing laboratories and at the Waco testing facility. All tests are witnessed and certified by an independent testing laboratory. All tests are conducted in compliance with the Scaffold and Shoring Institute testing procedures.

The "Hi-Load" frames are manufactured of electric resistant welded high strength structural steel tubing having the following properties:
1) Yield Strength $=50,000 \mathrm{psi}$
2) Tensile Strength $=75,000 \mathrm{psi}$
3) Elongation in 2 in. is 23 percent

Properties of the frame leg material are as follows:
1) Outside diameter
$\mathrm{D}=2.375 \mathrm{in}$
2) Wa11 Thickness
$\mathrm{t}=0.154 \mathrm{in}$
3) Area
$\mathrm{A}=1.075$ in $^{2}$
4)
Moment of Intertia
$I=0.666$ in $^{4}$
5) Section Modulus
$S=0.561 \mathrm{in}^{3}$
6) Radius of Gyration $R=0.787$ in

The failure (see Test \#1) occurred in the plane of the connecting crossbraces. The resulting test loads can be equated to the Eulers column design load.

Additional tests and testing programs were initiated to determine the effect of screw and staff at various extensions. The results of all these tests are shown in Tables 1 and 2. These Tables reflect a $2 \frac{1}{2}: 1$ minimum safety factor as required by the Federal Occupational Safety and Health Act and the S.S.I.

Test \#2 (as illustrated) was performed on a three 6'-0" frames high tower which contained four staff and staff attachments with interchangeable heads at the top and base plate at the bottom of the tower.

Properties of the Staff Extension Material are as follows:
1) Outside Diameter
$D=1.900 \mathrm{in}$
2) Wall Thickness
$t=.132$ in
3) Area
$\mathrm{A}=.733 \mathrm{in}$
4) Moment of Inertia
$I=.288 \mathrm{in}$ 

5) Section Modulus
$\mathrm{S}=.303 \mathrm{in}$
6) Radius of Gyration
$\mathrm{R}=.627 \mathrm{in}$

The staff which slides inside the legs of the top frame of the tower is supported by a pin which is placed thru the staff and supported on the staff attachment "Speedset."

Failure of the tower was confined to the top Staff Extension. The failure of the staff was short column failure which can occur in either plane. The ultimate load can be equated with the Euler's column design load.

Table 2 is a result of extensive testing of the "Hi-Load" frames with staffs. The table reflects a minimum $2 \frac{1}{2}: 1$ safety factor as recommended by the Scaffold \& Shoring Institute and OSHA. 


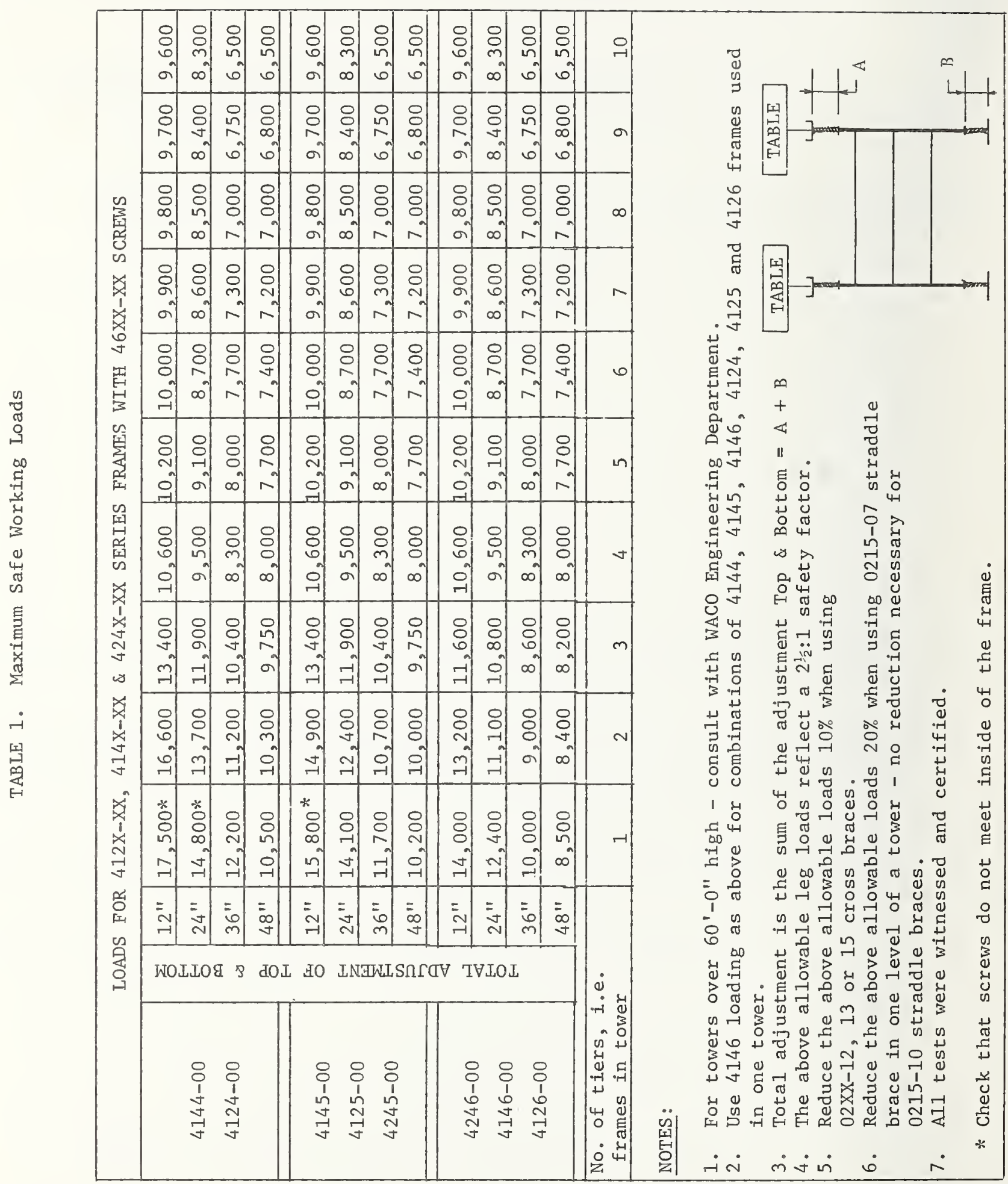


TABLE 2. Allowable Load on Staffs 4805-XX (1.b)

\begin{tabular}{|c|c|c|c|c|c|c|c|c|c|}
\hline$\overline{\text { STAFF }}$ & & & & NUMBER & F FRAMES & $\mathrm{HIGH}$ & & & \\
\hline EXTENSION & 1 TIER & 2 TIERS & 3 TIERS & 4 TIERS & 5 TIERS & 6 TIERS & 7 TIERS & 8 TIERS & 9 TIERS \\
\hline $1^{\prime}-0 "$ & 9100 & 8600 & 8100 & 7800 & 7500 & 7400 & 7300 & 7200 & 7000 \\
\hline $2^{\prime}-0^{\prime \prime}$ & 8500 & 7500 & 6900 & 6550 & 6200 & 6050 & 5900 & 5700 & 5500 \\
\hline $3^{\prime}-0^{\prime \prime}$ & 7300 & 6500 & 5700 & \multirow{3}{*}{\multicolumn{6}{|c|}{$\begin{array}{l}\text { USE } 3 \text { FRAME HIGH VALUES FOR } 4 \text { THRU } 9 \text { FRAMES HIGH IF } \\
\text { TOWER IS SECURELY BRACED IN BOTH DIRECTIONS WITH } \\
2 \times 6 \text { TIMBER LACING AND } 4432-00 \text { NAILING PLATES AT A } \\
\text { MAXIMUM SPACING OF EVERY THIRD FRAME UP THE TOWER. }\end{array}$}} \\
\hline $4^{\prime}-0^{\prime \prime}$ & 6500 & 5550 & 4600 & & & & & & \\
\hline $5^{\prime}-0^{\prime \prime}$ & 6000 & 4750 & 3800 & & & & & & \\
\hline
\end{tabular}

\section{NOTES:}

1. All values reflect a minimum $2 \frac{1}{2}: 1$ safety factor.

2. Consult with WACO Engineering Department for situations not covered.

3 . Use the above loading for tower combinations of $4144,4145,4146,4124,4125$, and 4126 frames.

4. Staff extension is the sum of the screw and staff adjustment top and bottom.

5. All tests were witnessed and certified. 


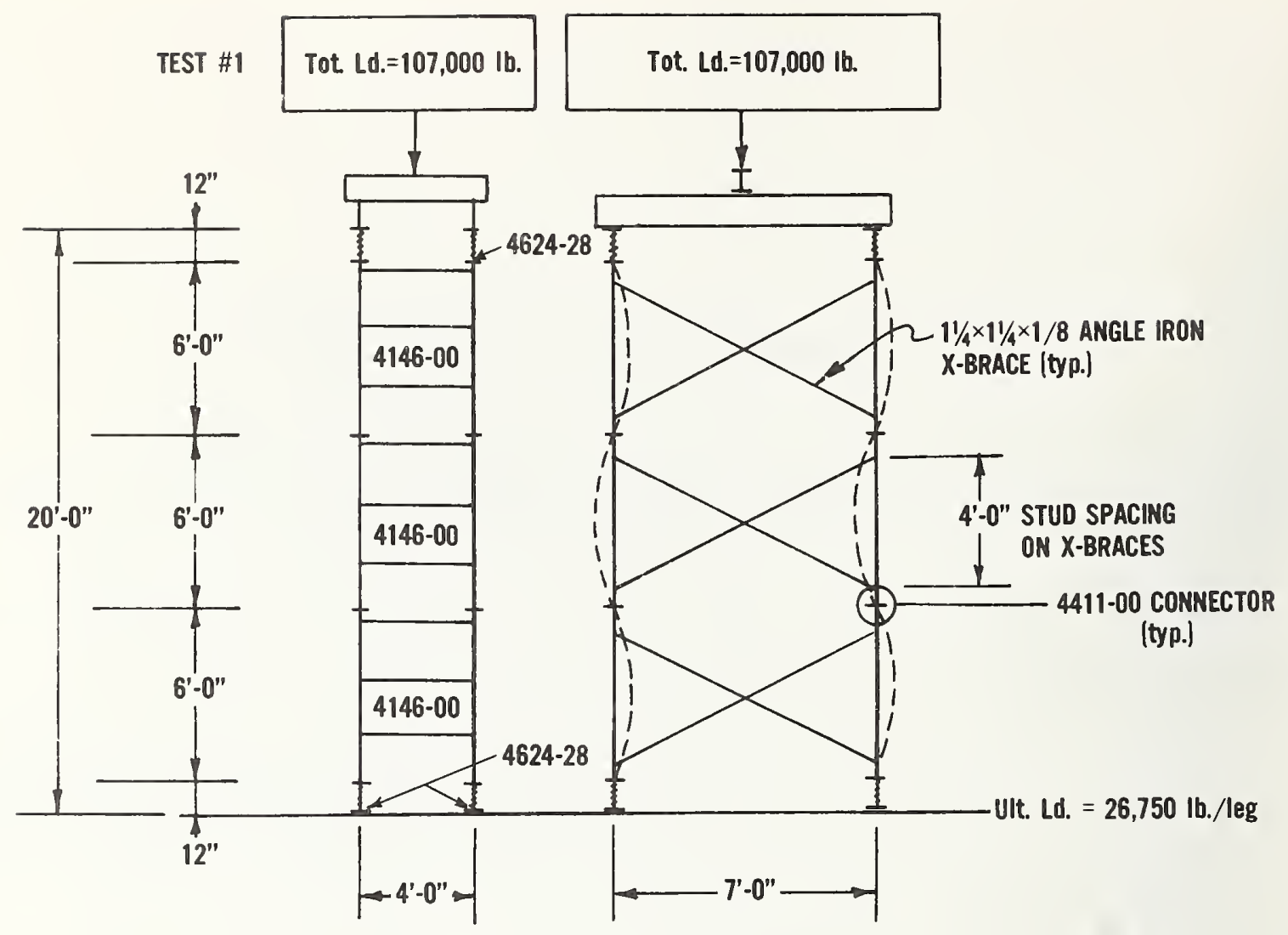

TEST \#2

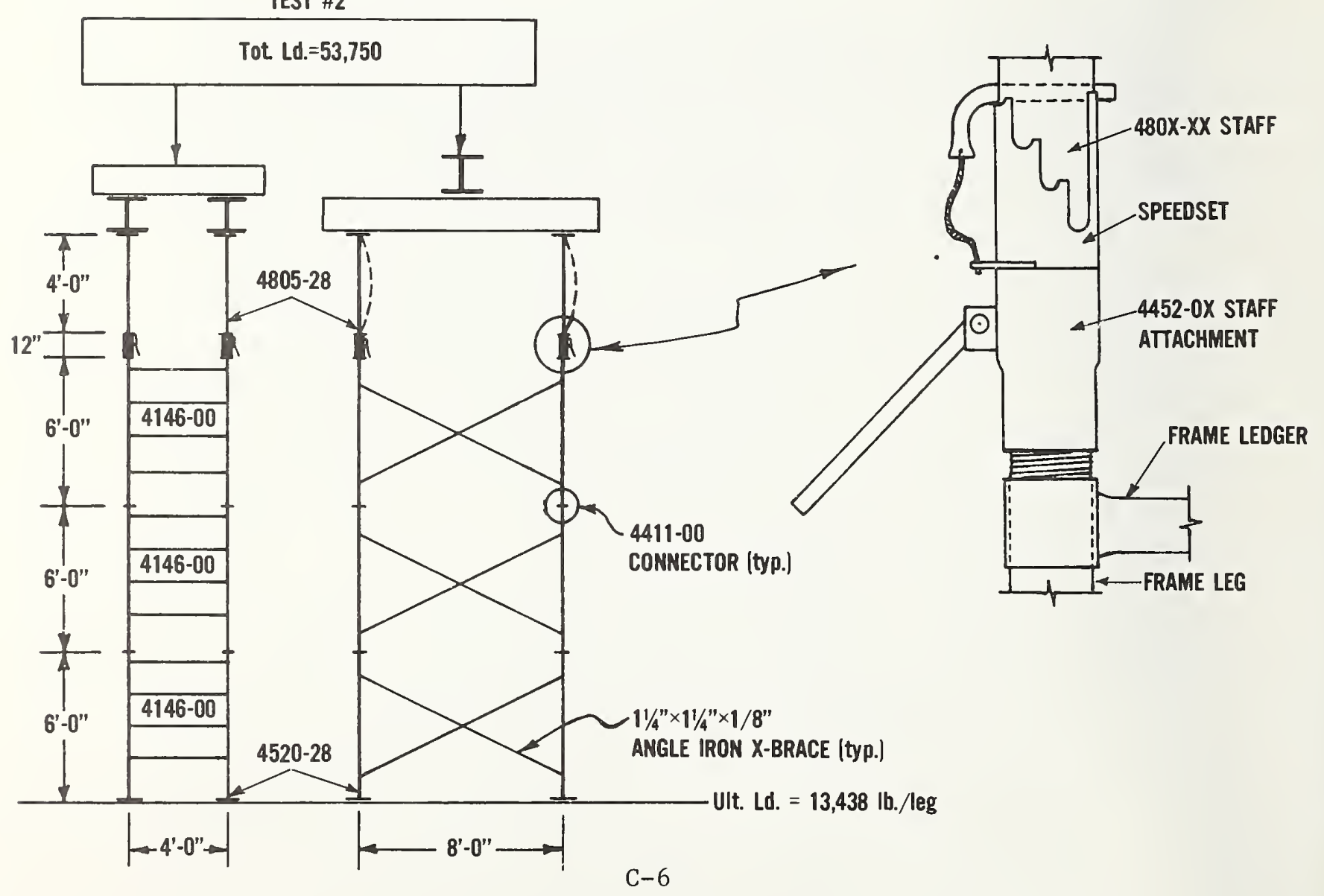



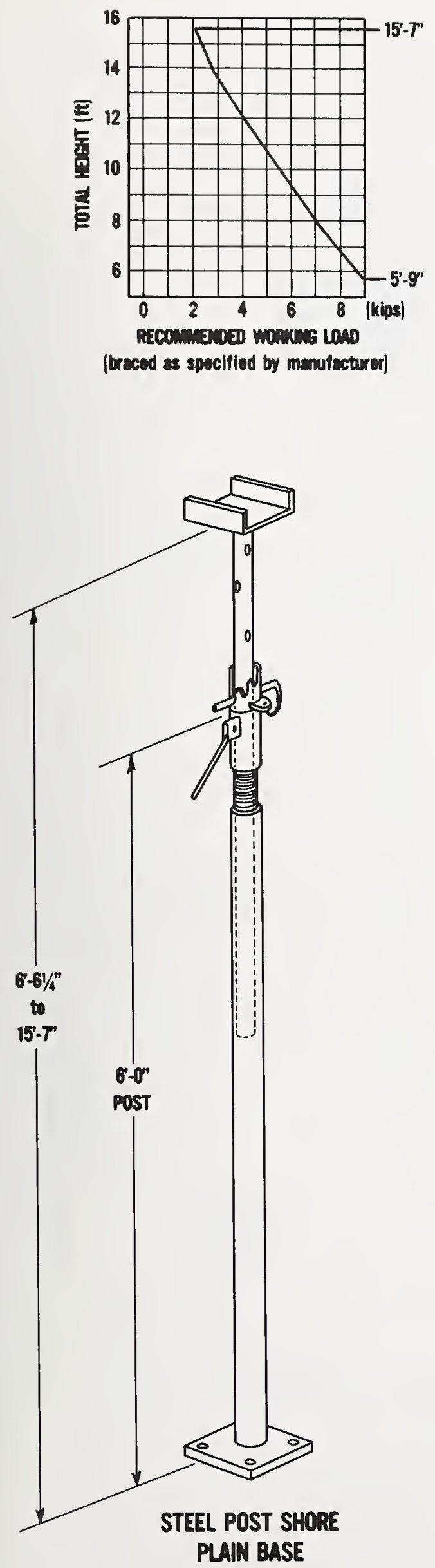

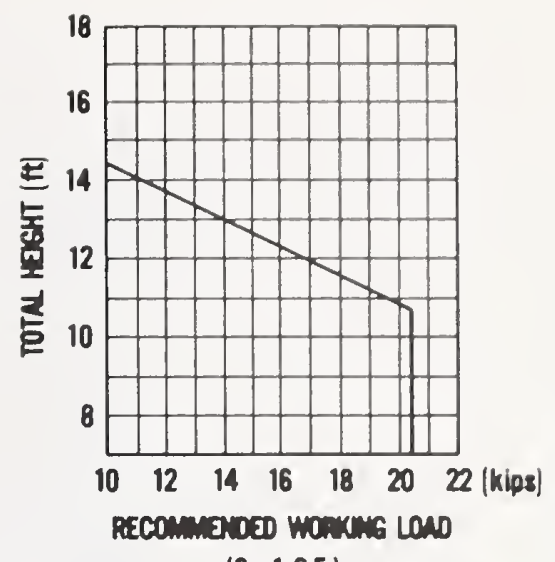

(3:1 S.F.)

(braced as specifiad by menufacturer)

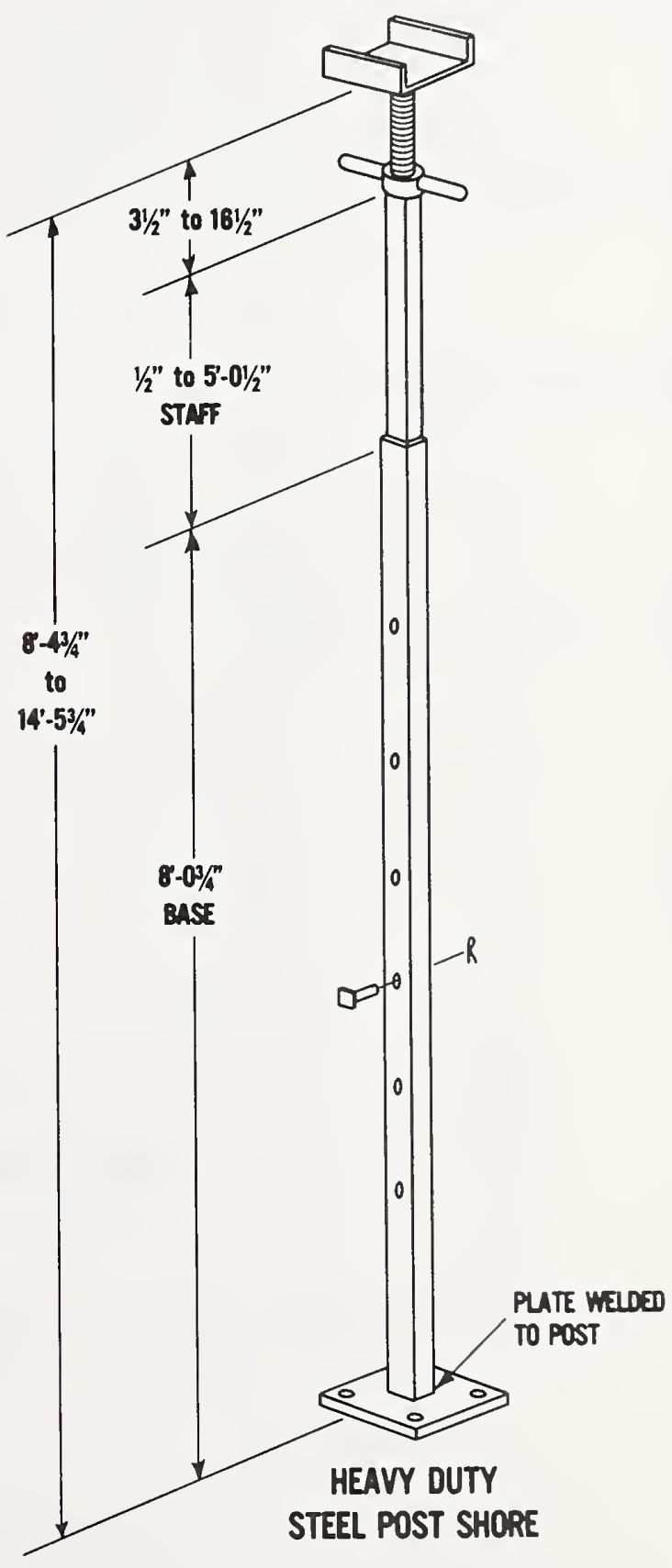




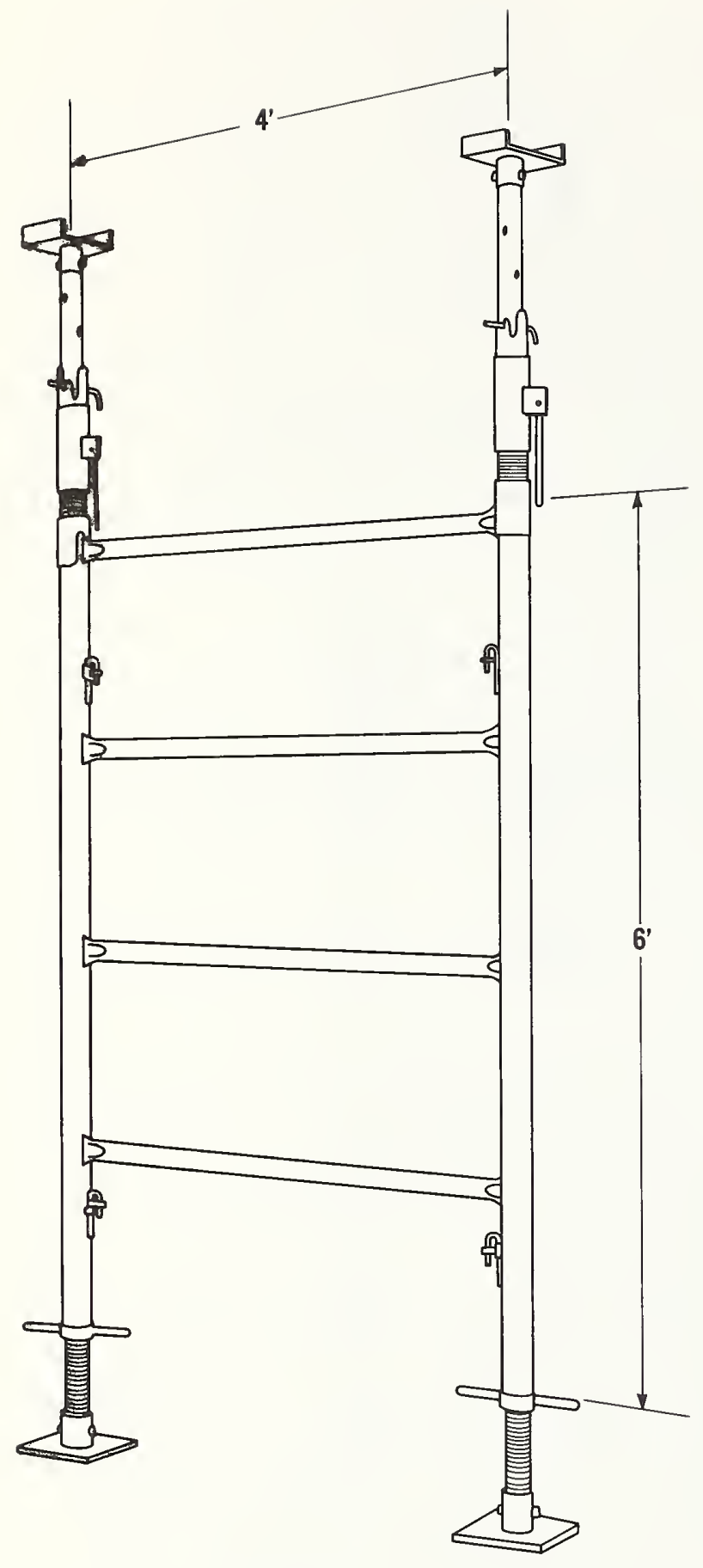

\#4146-00

Wt. 67 lbs.

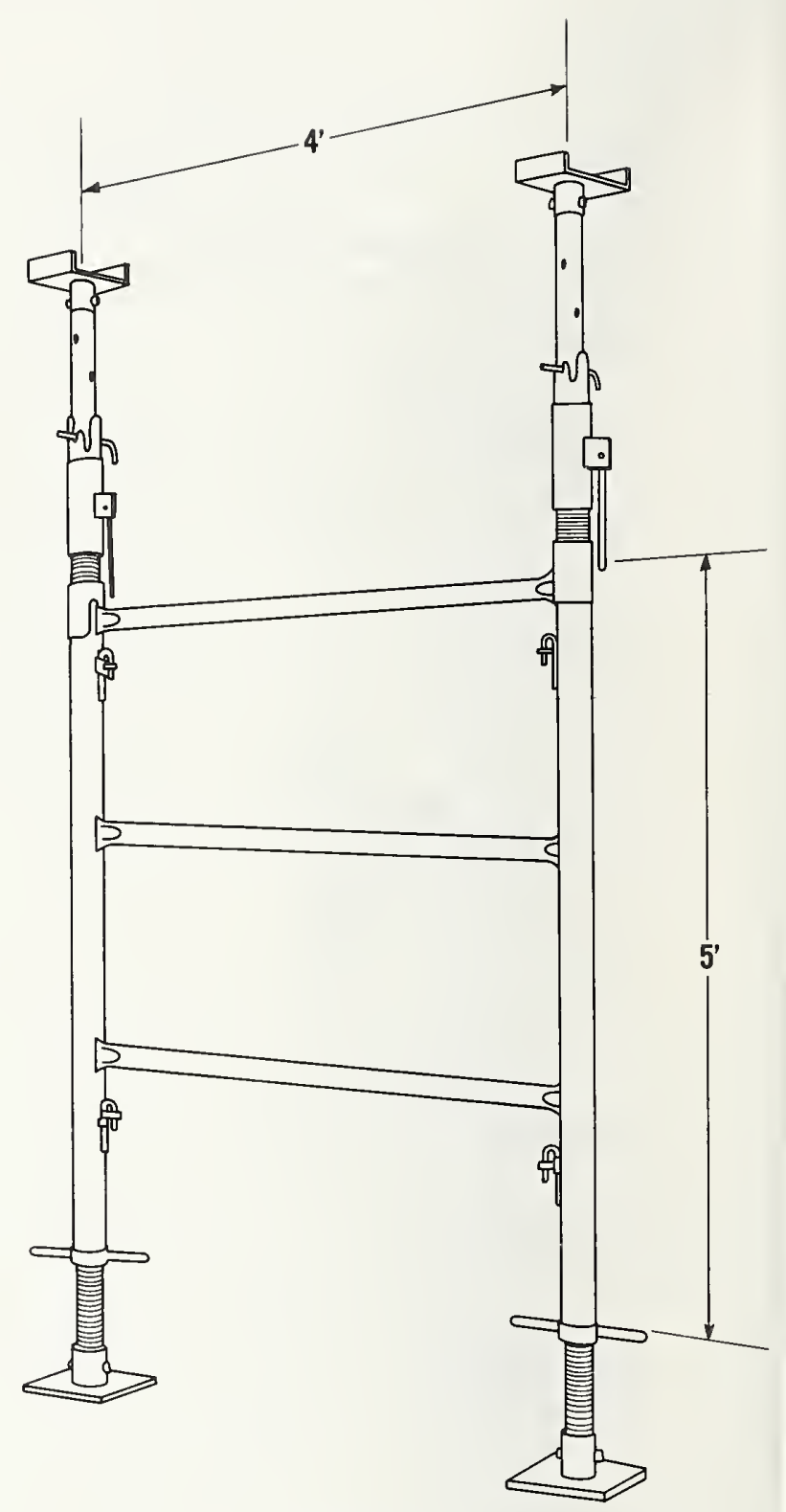

\#4145-00

Wt. 54 lbs.

SHORING FRAME ASSEMBLIES 


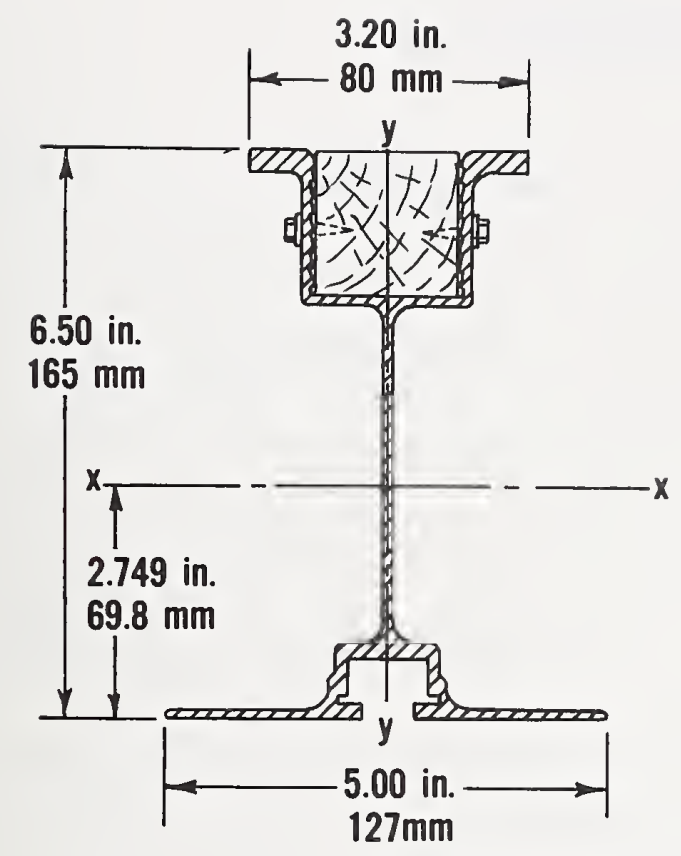

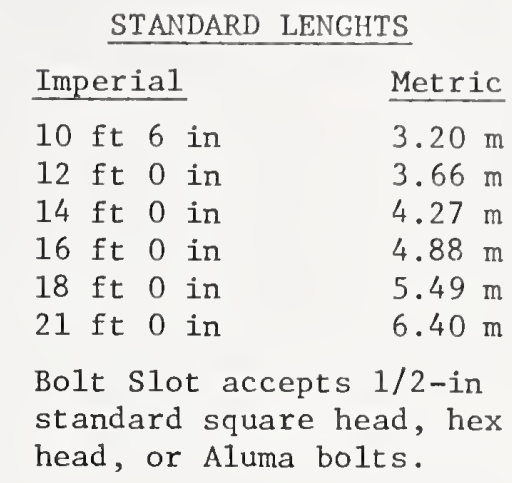

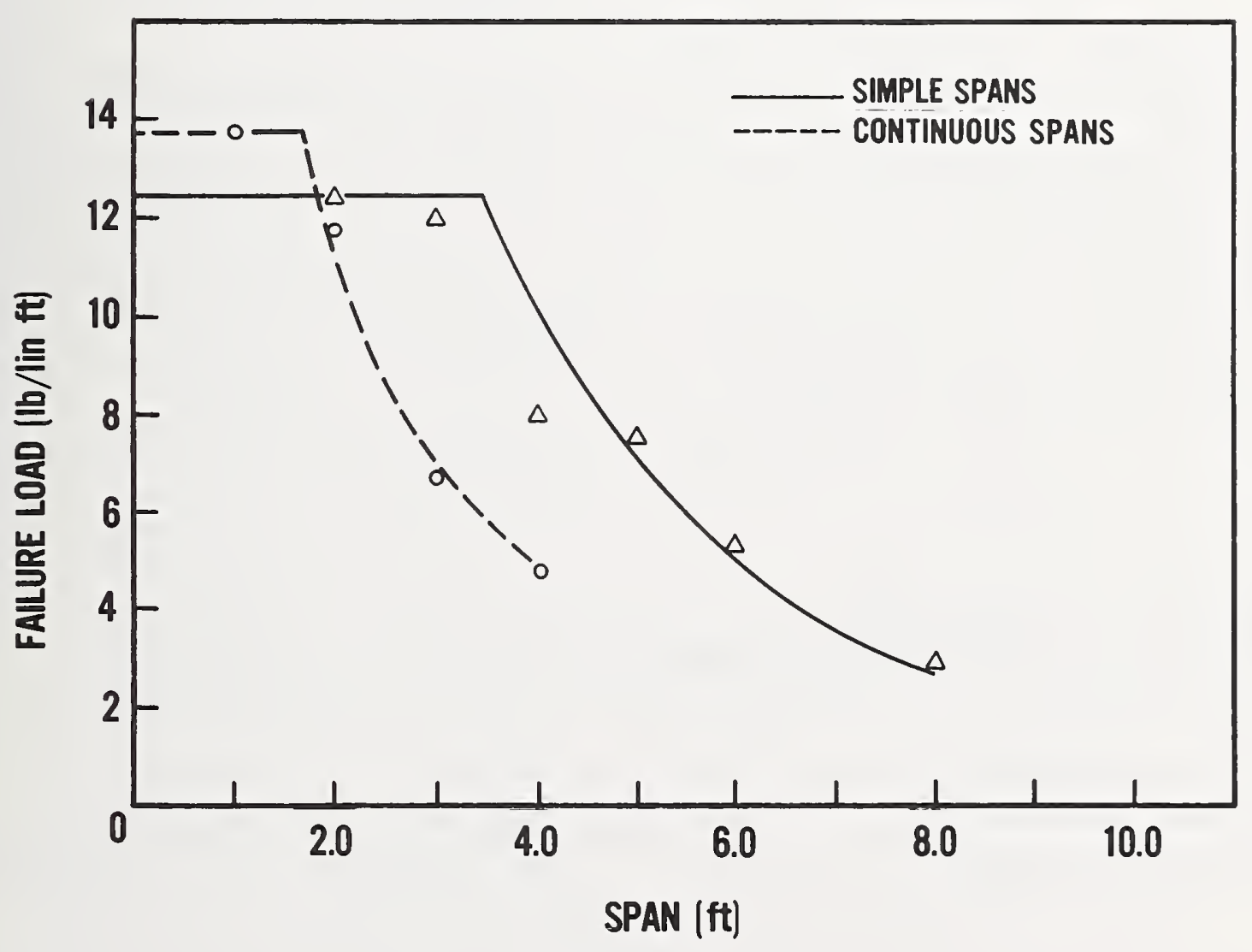

C-9 
REFERENCE

Strength of Alum'n Alcan 4th Ed'n

Strength of Alum'n Alcan 4th Ed'n

(with F.O.S.=2.2)

CSA S-157

C.P. 118

\author{
REACTION WITH \\ FULL BEARING
}

kips $\quad \mathrm{kN}$

$23.1 \quad 103$

$10.5 \quad 46.7$

$14.4 \quad 64$

$10.7 \quad 47.7$
REACTION WITH

PARTIAL BEARING

kips $\quad \mathrm{kN}$

$11.6 \quad 51.6$

$5.3 \quad 23.4$

$7.5 \quad 33.4$

13.962
CONCENTRATED

LOAD

kips $\mathrm{kN}$

22.299

10.144 .9

SECTIONAL AND ELASTIC PROPERTIES

\section{IMPERIAL}

Overall height . . . . . . . . . 6.50 in.

Base width . . . . . . . . . . . 5.00 in.

Width, inverted top hat section . . . . . 3.20 in.

Cross sectional area

$$
\text { (excluding } 2^{\prime \prime} \times 2^{\prime \prime} \text { nailing strip) . . . . } 2.65 \text { in. }{ }^{2}
$$

Nomina1 weight

(including $2^{\prime \prime} \times 2^{\prime \prime}$ nailing strip) . . . . $41 \mathrm{~b} . / \mathrm{ft}$.

Distance of neutral axis from base . . . . 2.749 in.

(when beam is clamped or loaded)

Moment of Inertia $I_{x-x} \cdot$. . . . . . . 16.882 in. $^{4}$

Moment of Inertia $I_{y-y}$. . . . . . . 2.657 in. ${ }^{4}$

Section Modulus $\mathrm{S}_{\mathrm{x}-\mathrm{x}}$

about the lower chord/flange ...... 6.141 in 3

about the upper chord/inverted top hat section 4.50 in. 3

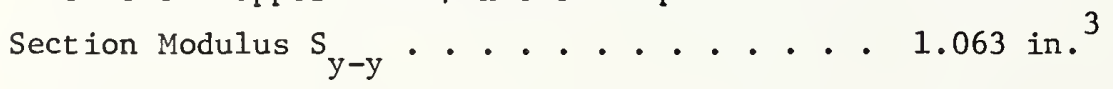

Radius of Gyration $\mathrm{r}_{\mathrm{x}}$. . . . . . . . 2.518 in.

Radius of Gyration $\mathrm{r}_{\mathrm{y}}$............ $1.00 \mathrm{in}$.

Modulus of Elasticity E . . . . . . . $10.2 \times 10^{6}$ psi
METRIC

$165 \mathrm{~mm}$

$127 \mathrm{~mm}$

$80 \mathrm{~mm}$

$1710 \mathrm{~mm}^{2}$

$6 \mathrm{~kg} / \mathrm{m}$

$69.8 \mathrm{~mm}$

$703 \mathrm{~cm}^{4}$

$110.6 \mathrm{~cm}^{4}$

$110 \mathrm{~cm}^{3}$

$73.75 \mathrm{~cm}^{3}$

$17.42 \mathrm{~cm}^{3}$

$63.9 \mathrm{~mm}$

$25.3 \mathrm{~mm}$

$7.04 \times 10^{5} \mathrm{kN} / \mathrm{cm}^{2}$ 


\begin{tabular}{|c|c|c|c|c|}
\hline & & & IMPERIAL & METRIC \\
\hline Torsion Constant & $\mathrm{J}$ & $=$ & 0.027 in. $^{4}$ & $1.124 \mathrm{~cm}^{4}$ \\
\hline Warping Constant & $\mathrm{H}$ & $=$ & 28.0 in. $^{6}$ & $7519.0 \mathrm{~cm}^{6}$ \\
\hline $\begin{array}{l}\text { Slenderness Ratio (local } \\
\text { buckling Bottom Flange) } \\
=\frac{M B}{t}, M=4.5\end{array}$ & $\lambda$ & $=$ & 60 & 60 \\
\hline $\begin{array}{l}\text { Maximum Buckling Stress } \\
\text { Bottom Flange }\end{array}$ & $\mathrm{F}_{\mathrm{C}}$ & $=$ & $26 \mathrm{ksi}$ & $17.93 \mathrm{kN} / \mathrm{cm}^{2}$ \\
\hline $\begin{array}{l}\text { Maximum B.M. (local buckling } \\
\text { Bottom Flange) }\end{array}$ & M & $=$ & 160 kip in. & $18.08 \mathrm{kN} \cdot \mathrm{m}$ \\
\hline $\begin{array}{l}\text { Maximum Permissible - Bottom } \\
\text { Flange (F.0.S. 2.2) }\end{array}$ & M & $=$ & 72.5 kip in. & $8.19 \mathrm{kN} \cdot \mathrm{m}$ \\
\hline $\begin{array}{l}\text { Slenderness Ratio: (buckling } \\
\text { due to Lateral Instability, } \\
\text { with } 4^{\prime} 6 \text { " long cantilever) }\end{array}$ & $\lambda$ & $=$ & 73 & 73 \\
\hline $\begin{array}{l}\text { Maximum Buckling Stress - } \\
\text { Lateral Instability }\end{array}$ & $\mathrm{F}_{\mathrm{c}}$ & $=$ & 19 ksi & $13.10 \mathrm{kN} / \mathrm{cm}$ \\
\hline $\begin{array}{l}\text { Maximum B.M. - Lateral } \\
\text { Instability }\end{array}$ & M & $=$ & 116.7 kip in. & $13.18 \mathrm{kN} \cdot \mathrm{m}$ \\
\hline $\begin{array}{l}\text { Maximum Permissible B.M. - } \\
\text { Lateral Instability (F.O.S. 2.2) }\end{array}$ & M & $=$ & 53 kip in. & $5.99 \mathrm{kN} \cdot \mathrm{m}$ \\
\hline $\begin{array}{l}\text { Slenderness Ratio (local buckling } \\
\text { - top chord) }\end{array}$ & $\lambda$ & $=$ & 14 & 14 \\
\hline $\begin{array}{l}\text { Maximum Buckling Stress - } \\
\text { top chord }\end{array}$ & $F_{c}$ & $=$ & $37 \mathrm{ksi}$ & $25.51 \mathrm{kN} / \mathrm{cm}^{2}$ \\
\hline $\begin{array}{l}\text { Maximum B.M. (local buckling - } \\
\text { top chord) }\end{array}$ & M & $=$ & $166.5 \mathrm{kip}$ in. & $18.81 \mathrm{kN} \cdot \mathrm{m}$ \\
\hline Maximum Permissible B.M. - & $M$ & $=$ & 76 kip in. & $8.59 \mathrm{kN} . \mathrm{m}$ \\
\hline
\end{tabular}


ALLOWABLE LOAD CHARTS FOR $4 \times 4$ SHORES

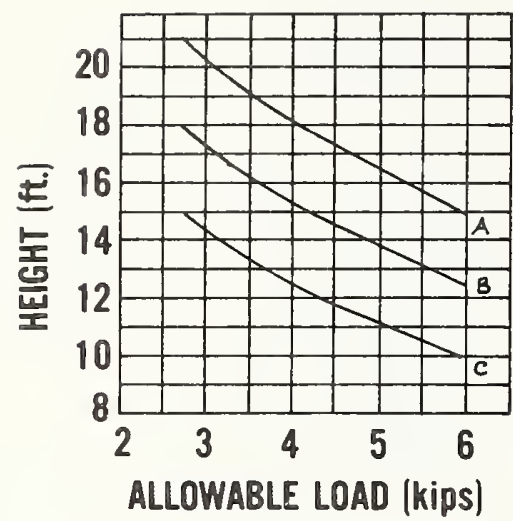

TEST RESULTS

\begin{tabular}{|c|c|}
\hline $\begin{array}{c}\text { Load per } \\
\text { shore } \\
\text { (kips) }\end{array}$ & $\begin{array}{c}\text { Deflection, } \\
2 \text { clamps } \\
\text { per shore } \\
\text { (in) }\end{array}$ \\
\hline 1 & 0 \\
\hline 2 & .005 \\
\hline 3 & .021 \\
\hline 4 & .063 \\
\hline 5 & .127 \\
\hline 6 & .172 \\
\hline 7 & .213 \\
\hline 8 & .249 \\
\hline 9 & .319 \\
\hline 10 & .449 \\
\hline
\end{tabular}

NOTES

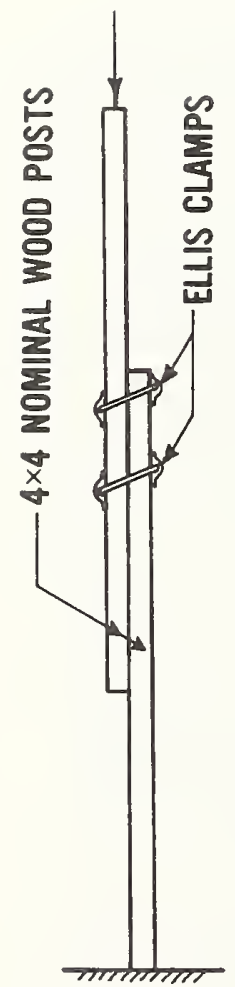

\section{Allowable Load Charts:}

* Curve A: Braced both directions at third points

* Curve B: Braced both directions at mid-point

* Curve C: Unbraced

* Chart is for vertical loads only.

* Every shore should be braced against lateral movement.

* Allowable maximum value of $6000 \mathrm{lb}$. per shore is based upon a safety factor of 3 against failure of the mechanical mechanism of splice joint.

* Chart is based upon allowable unit stresses of 1500 psi for wood members of fir or yellow pine, free of knots. Chart is based upon approved engineering standards, but does not compensate for unusual conditions. The final accepted supporting framing should be approved by a Registered Professional Engineer.

\section{Test Results:}

$*$ The tests were made with ELLIS clamps on No. 1 Douglas Fir ELLIS sticks; clamps were driven down with a carpenter's hammer before the load came on.

* The ELLIS jack, as is, will lift $1400 \mathrm{lb}$. with a 3-ft. piece of pipe slipped on the handle, the jack will lift $30001 \mathrm{~b}$.

* Shores were $11 \mathrm{ft}$. long and were tested under increasing loads of up to $20,0001 \mathrm{~b}$. without breaking. There was very slight deflection at $6,000 \mathrm{lb}$, and progressive deflection up to $20,000 \mathrm{lb}$. (see test results above). * ELLIS method assures a 2:1 safety factor. 
NBS-114A (REV. 2-8C)

U.S. DEPT. OF COMM.

BIBLIOGRAPHIC DATA

SHEET (See instructions)

1. PUBLICATION OR

REPORT NO.

NBS BSS 146

2. Performing Organ. Report Nof 3. Publication Date

February 1983

4. TITLE AND SUBTITLE

Evaluation of Construction Loads in Multistory Concrete Buildings

5. $A \cup T H O R(S)$

S.G. Fattal

6. PERFORMING ORGANIZATION (If joint or other than NBS, see instructions)

NATIONAL BUREAU OF STANDARDS

DEPARTMENT OF COMMERCE

WASHINGTON, D.C. 20234

Final

9. SPONSORING ORGANIZATION NAME AND COMPLETE ADDRESS (Street, City, State, ZIP)

. ContracV Grant No.

The occupational Safety and Health Administration

U.S. Department of Iabor

Washington, DC 20001

10. SUPPLEMENTARY NOTES

Library of Congress Catalog Card Number: 82-600579

$\square$ Document describes a computer program; SF-185, FIPS Software Summary, is attached.

11. ABSTRACT (A 200-word or less factual summary of most significant information. If document includes a significant bibliography or literoture survey, mention it here)

Construction loads in a multistory flat plate concrete building were measured using strain-gaged metal shores and an analog recorder. The instrumented shores were placed within an interior bay of the third story under the formwork for the fourth story floor slab, and loads on the shores were measured continuously over a 24-hour period during the casting and partial curing cycle of that slab. The loads on some of these shores, when subsequently used as reshores in the same bay, were measured during an 8-hour period which included the casting of the fifth story floor slab. A time-lapse camera, operating synchronously with the load data acquisition system, gathered simultaneous photographic evidence of the construction activities during load monitoring periods. This report presents a complete documentation of the field data in compact form for subsequent use in related studies. The load data is interpreted and compared with construction load and design provisions of current standards.

12. KEY WORDS (Six to twelve entries: alphabetical order: capitalize only proper names; and separate key words by semicolons) concrete buildings; concrete casting; construction loads; construction standards; falsework; field measurements; flat plate; floor slab; formwork; instrumented shores; load measurement; multistory construction; shored construction.

13. AVAILABILITY

[X] Unlimited

For Official Distribution. Do Not Release to NTIS

14. NO. OF

PRINTED PAGES

[] Order From Superintendent of Documents, U.S. Government Printing Office, Washington, D.C. 20402.

139

15. Price

[.] Order From National Technical Information Service (NTIS), Springfield, VA. 2216I 




\section{NBS TECHNICAL PUBLICATIONS}

\section{PERIODICALS}

JOURNAL OF RESEARCH-The Journal of Research of the National Bureau of Standards reports NBS research and development in those disciplines of the physical and engineering sciences in which the Bureau is active. These include physics, chemistry, engineering, mathematics, and computer sciences. Papers cover a broad range of subjects, with major emphasis on measurement methodology and the basic technology underlying standardization. Also included from time to time are survey articles on topics closely related to the Bureau's technical and scientific programs. As a special service to subscribers each issue contains complete citations to all recent Bureau publications in both NBS and nonNBS media, Issued six times a year. Annual subscription: domestic \$18: foreign $\$ 22.50$. Single copy, $\$ 5.50$ domestic; $\$ 6.90$ foreign.

\section{NONPERIODICALS}

Monographs-Major contributions to the technical literature on various subjects related to the Bureau's scientific and technical activities.

Handbooks-Recommended codes of engineering and industrial practice (including safety codes) developed in cosperation with in. terested industries, professional organizations, and regulatory bodies.

Special Publications-Include proceedings of conferences sponsored by NBS, NBS annual reports, and other special publications appropriate to this grouping such as wall charts, pocket cards, and bibliographies.

Applied Mathematics Series-Mathematical tables, manuals, and studies of special interest to physicists, engineers, chemists, biologists, mathematicians, computer programmers, and others engaged in scientific and technical work.

National Standard Reference Data Series-Provides quantitative data on the physical and chemical properties of materials, compiled from the world's literature and critically evaluated. Developed under a worldwide program coordinated by NBS under the authority of the National Standard Data Act (Public Law 90-396).

NOTE: The principal publication outlet for the foregoing data is the Journal of Physical and Chemical Reference Data (JPCRD) published quarterly for NBS by the American Chemical Society (ACS) and the American Institute of Physics (AIP). Subscriptions, reprints, and supplements available from ACS, 1155 Sixteenth St., NW, Washington, DC 20056.
Building Science Series-Disseminates technical informatton developed at the Bureau on building materials, components, systems, and whole structures. The series presents research results, test methods, and performance criteria related to the structural and environmental functions and the durability and safety characteristics of building elements and systems.

Technical Notes-Studies or reports which are complete in themselves but restrictive in their treatment of a subject. Analogous to monographs but not so comprehensive in scope or definitive in treatment of the subject area. Often serve as a vehicle for final reports of work performed at NBS under the sponsorship of other government agencies.

Voluntary Product Standards-Developed under procedures published by the Department of Commerce in Part 10, Title 15, of the Code of Federal Regulations. The standards establish nationally recognized requirements for products, and provide all concerned interests with a basis for common understanding of the characteristics of the products. NBS administers this program as a supplement to the activities of the private sector standardizing organizations.

Consumer Information Series-Practical information, based on NBS research and experience, covering areas of interest to the consumer. Easily understandable language and illustrations provide useful background knowledge for shopping in today's technological marketplace.

Order the above NBS publications from: Superintendent of Documents, Government Printing Office, Washington. DC 20402.

Order the following NBS publication.S-FIPS and NBSIR's-from the National Technical Information Service. Springfield, VA 22161.

Federal Information Processing Standards Publications (FIPS PUB)-Publications in this series collectively constitute the Federal Information Processing Standards Register. The Register serves as the official source of information in the Federal Government regarding standards issued by NBS pursuant to the Federal Property and Administrative Services Act of 1949 as amended, Public Law 89-306 (79 Stat. 1127), and as implemented by Executive Order 11717 (38 FR 12315, dated May 11, 1973) and Part 6 of Title 15 CFR (Code of Federal Regulations).

NBS Interagency Reports (NBSIR)-A special series of interim or final reports on work performed by NBS for outside sponsors (both government and non-government). In general, initial distribution is handled by the sponsor: public distribution is by the National Technical Information Service, Springfield, VA 2216I. in paper copy or microfiche form. 
U.S. Department of Commerce

National Bureau of Standards

Washington, D.C. 20234

Official Business

U.S.MAIL

Penalty for Private Use $\$ 300$

POSTAGE AND FEES PAID US. DEPARTMENT OF COMMERCE COM-215

THIRD CLASS

BULK RATE 